\title{
CONTROLE SOCIAL E GESTÃO PARTICIPATIVA EM SAÚDE PÚBLICA A EXPERIÊNCIA DE CONSELHOS GESTORES DE UNIDADES DE SAÚDE DO MUNICÍPIO DE CAMPO GRANDE/M.S - 1994/2002
}

\section{MILCA LOPES DE OLIVEIRA}

Tese de Doutorado apresentada ao Departamento de Práticas de Saúde Pública da Faculdade de Saúde Pública da Universidade de São Paulo para obtenção do Grau de Doutor.

Área de Concentração: Serviços de Saúde

ORIENTADOR: PROF. DR. EURIVALDO SAMPAIO DE ALMEIDA

São Paulo

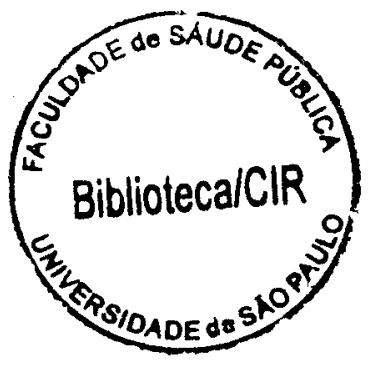




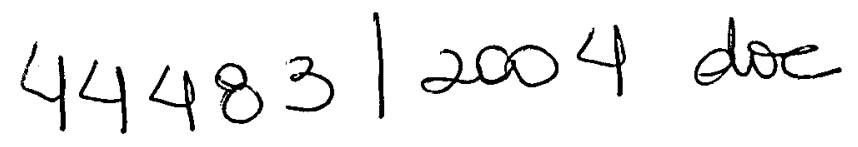

Autorizo, exclusivamente, para fins acadêmicos e científicos, a reprodução total ou parcial deste tese, por processos fotocopiadores.

Assinatura:

Data: 08 de outubro de 2003. 
Dedico este estudo aos conselheiros dos Conselhos de Unidades de Saúde de Urgência - Emergência de Campo Grande/M.S pelo espírito de luta, dedicação, credibilidade e por acreditarem num processo participativo de gestão em Saúde 
"Não havendo sábia direção cai o povo, mas na multidão de conselheiros há segurança". (BÍBLIA, Prov. 11: 14)

“(...) na multidão de conselheiros está a vitória". (BÍBLIA, Prov. 24:6)

"Os planos mediante os conselhos têm bom êxito". (BÍBLIA, Prov. 20: 18) 


\section{AGRADECIMENTOS}

A DEUS, meu Pai, meu Protetor, meu Sustentáculo nos diversos momentos deste estudo, dando-me, sempre, perseverança, principalmente, quando as energias físicas pareciam não restar mais.

À minha família - esposo, filhos e noras, pelos momentos de ausência que me permitiram furtar e, também, pelas palavras de estímulo que me faziam avançar.

À Maura Eduarda - minha sobrinha, pois esteve sempre pronta para digitar toda a tabulação dos dados documentais.

Aos meus alunos, pelas ausências de alguns momentos, com os quais pude discutir muitas situações vividas neste estudo, servindo, inclusive, como instrumento didático-pedagógico.

Às minhas amigas Deyse, Lourdes Marci, Camila, Eliethe e muitos outros, por compartilharem comigo das apreensões, naturais de um estudo deste quilate, disponibilizando-me momentos de amizade e descontração.

À Secretária de Saúde do município de Campo Grande/MS - Beatriz Dobachi, pela confiança, credibilidade e interesse imediato por este estudo.

Às gerentes das Unidades de Saúde dos Conselhos estudados, pela facilidade e disponibilidade em me fornecer os documentos necessários para as análises.

Aos funcionários da SESAU de Campo Grande - Dora, Neta, Geovani, Leonardo, Lauriane, Emailde, pela prontidão, atenção e carinho durante a fase de coleta de dados e conclusão final da redação da Tese, dirimindo as dúvidas e fornecendo algumas informações, ainda, necessárias.

Aos conselheiros de saúde dos Conselhos estudados, por colaborarem em dirimir as dúvidas, sempre, quando existiam.

Ao Prof ${ }^{\circ}$ Dr. Eurivaldo Sampaio de Almeida, meu orientador, que com firmeza e experiência me conduziu nesta trajetória, conferindo-me a 
segurança necessária, principalmente, nos momentos finais da redação da Tese.

À Prof ${ }^{a}$ Márcia Faria Westphal, pela sua experiência nesta temática e discussões tão pertinentes para a finalização da Tese.

Às secretárias do Núcleo de Estudos e Pesquisas de Sistemas de Saúde NEPESS - do Departamento de Práticas de Saúde Pública, Margareth e Maria do Carmo, pela atenção e prontidão em todos os momentos do desenvolvimento deste estudo.

Ao Centro Universitário Adventista de São Paulo - UNASP, pelo apoio e pela infra-estrutura disponibilizada para este estudo. 


\section{ÍNDICE}

Pg.

1. INTRODUÇÃO 1

1.1 A PARTICIPAÇÃO E O CONTROLE SOCIAL: CONCEITOS E 2 PERSPECTIVAS PARA O SISTEMA DE SAÚDE

1.2 ANTECEDENTES HISTÓRICOS 6

ANOS 60 - PERIODO DITATORIAL: movimento operário e 6

sindicatos

ANOS 70 - ABERTURA DEMOCRÁTICA: movimentos de 8

rua e novos sujeitos históricos

ANOS 80 - NOVA REPÚBLICA: (re) conquistando direitos sociais 10

ANOS 90 - PARTICIPAÇÃO SOCIAL INSTITUCIONALIZADA: 15

Os Conselhos Sociais

1.3 JUSTIFICATIVA

2. OBJETIVOS 29

2.1 OBJETIVO GERAL $\quad 30$

2.2 OBJETIVOS ESPECÍFICOS 30

3. METODOLOGIA 31

3.1 Objeto de estudo 32

3.2 Referencial de Análise $\quad 32$

3.3 Tipo de Estudo 36

3.4 Universo e Amostragem 38

3.5 Fontes de Dados 39

3.6 Instrumentos de Coleta de Dados 40

3.7 Etapas da Coleta de Dados 41

3.8 Periodo do Estudo 41

3.9 Questões Éticas deste Estudo 41 
5. A POLÍTICA DE CONTROLE SOCIAL NO ESTADO DE MATO GROSSO DO SUL/M.S - $1990-2000$.

5.1 CONTROLE SOCIAL E CONSELHO SOCIAL DE SAÚDE DO MATO GROSSO DO SUL -

5.2 CONTROLE SOCIAL E CONSELHO MUNICIPAL DE SAÚDE DE CAMPO GRANDE / M.S

5.3 CONTROLE SOCIAL E CONSELHOS GETORES DE UNIDADE DE 66 SAÚDE DO MUNICIPIO DE CAMPO GRANDE - M.S

6. DINÂMICA E FUNÇÃO DELIBERATIVA DOS CONSELHOS GESTORES 76 DOS CENTROS REGIONAIS DE SAÚDE: Influências na formulação de políticas de saúde - Campo Grande / M.S - 1994 / 2002

6.1 CONSELHO GESTOR DE SAÚDE DO CENTRO REGIONAL DE SAÚDE “ Dr. GÜINTER HANS” BAIRRO NOVA BAHIA DISTRITO NORTE - CAMPO GRANDE - M.S - 1994 / 2002

6.1.A ASPECTOS DO FUNCIONAMENTO DO CONSELHO GESTOR DO CRS "Dr. GÜINTER HANS" BAIRRO NOVA BAHIA - DISTRITO NORTE - CAMPO GRANDE - M.S 1994 / 2002

6.1.B DINÃMICA DO FUNCIONAMENTO DO CONSELHO GESTOR.: prática de atuação do Conselho

6.2. CONSELHO GESTOR DE SAÚDE DO CENTRO REGIONAL DE SAÚDE "Dr. JOÃO ROSA PIRES" BAIRRO AERO RANCHO DISTRITO SUL - 1997/2002

6.2.A ASPECTOS DO FUNCIONAMENTO DO CONSELHO GESTOR DO CRS 'Dr. JOÃO ROSA PIRES” BAIRRO AERO RANCHO - DISTRITO SUL - 1997/2002 
GESTOR: prática de atuação do Conselho.

6.3. CONSELHO GESTOR DE SAÚDE DO CENTRO REGIONAL DE 134 SAÚDE “ Dr. MARCILIO OLIVIERA LIMA” BAIRRO MORENINHA III - LESTE - 1996/ 2002

6.3.A ASPECTOS DO FUNCIONAMENTO DO CONSELHO 136 GESTOR DO CRS "Dr. MARCILIO OLIVIERA LIMA" BAIRRO MORENINHA III - LESTE - 1996/ 2002

6.3.B DINÃMICA DO FUNCIONAMENTO DO CONSELHO 138 GESTOR: prática de atuação do Conselho

6.4. CONSELHO GESTOR DE SAÚDE DO CENTRO REGIONAL DE SAÚDE "Dr. JOSÉ GERALDO ABUHASSAN" VILA ALMEIDA DISTRITO OESTE - CAMPO GRANDE - M.S - 1994 / 2002

6.4.A ASPECTOS DO FUNCIONAMENTO DO CONSELHO 154 GESTOR DO CRS 'Dr. JOSÉ GERALDO ABUHASSAN" VILA ALMEIDA - DISTRITO OESTE - CAMPO GRANDE M.S - $1994 / 2002$

6.4.B DINÃMICA DO FUNCIONAMENTO DO CONSELHO 158 GESTOR: prática de atuação do Conselho.

6.5 CONSELHO GESTOR DE SAÚDE DO CENTRO DE ESPECIALIDADES MÉDICAS DE CAMPO GRANDE/M.S./ CEM$1999 / 2002$

6.5.A ASPECTOS DO FUNCIONAMENTO DO CONSELHO GESTOR DO CENTRO DE ESPECIALIDADES MÉDICAS DE CAMPO GRANDE/ M.S./ CEM - 1999/2002

6.5.B DINÃMICA DO FUNCIONAMENTO DO CONSELHO 188 GESTOR: prática de atuação do Conselho.

7. ANÁLISE FINAL: CONSELHO GESTORES DE CENTROS REGIONAIS 200 DE SAÚDE - CAMPO GRANDE / M.S. - 1994/2002 
7.1 DIFICULDADES E AVANÇOS NO FUNCIONAMENTO DOS CONSELHOS

7.2 CONTROLE SOCIAL: LEGALIDADE $X$ LEGITIMIDADE

8. CONCLUSÃO

9. REFERÊNCIAS BIBLIOGRÁFICAS

ANEXOS

Anexo I-Formulário para os documentos

Anexo II - Roteiro de Observação AII

Anexo III - Questionário AIII

Anexo IV - Roteiro de Entrevista 
01 - Número de atendimentos médicos nos Distritos Sanitários de Campo

Grande/M.S e CEM - 2000

02 - Indicadores de saúde - 2000 - Campo Grande/M.S

03 - Relação das $1^{\mathrm{a}}$ e $2^{\mathrm{a}}$ etapas da campanha nacional de multivacinação

1999- 2000 - Campo Grande/M.S

04 -Dados Epidemiológicos das doenças de notificação compulsória

ocorridos no municipio de Campo Grande, por Distrito Sanitário

1999-2000

05 - Coeficiente de Mortalidade Proporcional por causas mais freqüentes

em Campo Grande - 1999-2000

06 - Periodicidade das reuniões do Conselho Gestor de saúde do CRS

'Dr. Güinter Hans" - B. Nova Bahia - Distrito Norte - Campo Grande 1994/2002

07 - Distribuição numérica dos tipos de decisões tomadas pelo Conselho Gestor de Saúde - Bairro Nova Bahia/Campo Grande - M.S, 1994 - 2002

08 - Periodicidade das reuniões do Conselho Gestor de Saúde do CRS

“Dr. João Rosa Pires" - B. Aero Rancho - Distrito Sul - Campo Grande 1997/2002

09 - Distribuição numérica dos tipos de decisões tomadas pelo Conselho

Gestor do CRS “Dr. João Rosa Pires” - Campo Grande/M.S - 1997/2002

10 - Periodicidade das reuniões do Conselho Gestor de saúde do CRS

"Dr. Marcílio Oliveira Lima" - Moreninha III - Distrito Leste - Campo Grande $1996 / 2002$

11 - Distribuição numérica dos tipos de decisões tomadas pelo Conselho

Gestor de saúde do CRS “Dr. Marcilio Oliveira Lima” - Moreninha III

Distrito Leste - Campo Grande - M.S, 1996/2002

12 - Periodicidade das reuniões do Conselho Gestor de Saúde do CRS

"José Gilberto Abuhassan" - V. Almeida - Distrito Oeste - 1994/2002

13 - Distribuição numérica dos tipos de decisões tomadas pelo Conselho

Gestor V. Almeida - Distrito Oeste - Campo Grande/M.S - 1994/2002 
14 - Periodicidade das reuniões do Conselho Gestor de Saúde do CEM

Campo Grande/M.S - 1999/2002

15 - Distribuição numérica dos tipos de decisões tomadas pelo Conselho

Gestor de Saúde - CEM - Campo Grande/M.S - 1999/2002

16 - Comparativo entre as datas de criação dos CG dos CRS estudados e do

CEM - Campo Grande/MS - 1994/2002

17 - Composição - por período de gestão - dos CG dos CRS estudados

e do CEM - Campo Grande/M.S - 1994/2002

18 - Número de Reuniões e número de presentes nas reuniões dos CG dos CRS estudados e do CEM - Campo Grande/MS - 1994 - 2002

19 - Distribuição numérica e comparativo dos tipos de decisões tomadas

pelos Conselhos Gestores de Saúde dos CRSs e CEM - Campo Grande - M.S, 1994/ 2002 
01 - Redações diferenciadas dos artigos $1^{\circ}$ e $6^{\circ}-$ Lei no $n^{\circ} .784 / 90$ - Campo

Grande/M.S

02 - Decisões/Encaminhamento do Conselho Gestor de Saúde do CRS

"Dr. Güinter Hans" - B. Nova Bahia - Distrito Norte - 1994/2002

03- Classificação das decisões/encaminhamentos do Conselho Gestor de Saúde do CRS "Dr. Güinter Hans" - Distrito Norte - Campo Grande/M.S - 1994/2002 04 - Decisões/encaminhamentos do Conselho Gestor de Saúde do CRS "Dr. João Rosa Pires" - Campo Grande/M.S - 1997/2002

05 - Classificação das decisões/encaminhamentos do Conselho Gestor de Saúde do CRS “João Rosa Pires" - B. Aero Rancho - Distrito Sul Campo Grande/M.S $-1997 / 2002$

06 - Encaminhamentos do Conselho Gestor de Saúde do CRS "Dr. Marcílio

Oliveira Lima" - B. Moreninha III - Distrito Leste - 1996/2002

07 - Classificação das decisões/encaminhamentos do Conselho Gestor de Saúde

do CRS "Dr. Marcílio Oliveira Lima" - B. Moreninha III - Distrito Leste 1996/2002

08 - Decisões/deliberações do Conselho Gestor de Saúde do Centro Regional de Saúde "Dr. José Geraldo Abuhassan" - Vila Almeida - Distrito Oeste - 1994/2002 09 - Classificação das decisões/deliberações do Conselho Gestor de Saúde do CRS “Dr. José Gilberto Abuhassan" - V. Almeida - Distrito Oeste - Campo Grande/M.S - 1994/2002

10 - Encaminhamentos/deliberações do Conselho Gestor de Saúde do Centro de Especialidades Médicas - CEM - Campo Grande/M.S 1999-2002

11- Classificação das Decisões/encaminhamentos do Conselho de Saúde do CEM - Campo Grande/M.S - 2002

12 - Pausas nas Reuniões dos CG dos CRS estudados e do CEM - Campo Grande/M.S - 1994/2002

13 - Paralelo entre vários documentos quanto às competências dos conselhos 


\section{RESUMO}

\section{OLIVEIRA ML. Controle Social e Gestão Participativa em Saúde Pública - a} experiência de Conselhos Gestores de Unidades de Saúde do município de Campo Grande/M.S - 1994/2002. São Paulo; 2003. [Tese de Doutorado - Faculdade de Saúde Pública/USP].

Objetivo. A trajetória da participação social no Brasil, evoluiu, desde os anos 60 , de movimento operário e sindicatos culminando num processo de institucionalização através dos Conselhos Sociais. Na Saúde Pública, esta participação foi legalizada pela Lei 8.142/90 na perspectiva do Controle Social. Neste contexto, este estudo tem como objetivo conhecer a prática do Controle Social e Gestão Participativa exercida em Conselhos de Unidades de Saúde. Metodologia. Foram feitos Estudos de Casos de 5 Conselhos, tendo como fontes principais os registros das Atas, a legislação e documentos do município e como referencial para análise do processo decisório um documento do ILPES/CLAPS (1975). Resultado. Os Conselhos se organizam em plenário com coordenador, secretário, composição, hoje, paritária, representatividade reduzida, periodicidade mensal e substituições freqüentes de conselheiros. $O$ funcionamento das reuniões se orienta por uma agenda ficando explícitas as demandas voltadas, predominantemente, para situação epidemiológica e serviços de saúde. $\mathrm{O}$ processo decisório contempla, com percentagem significativa, os elementos técnicoadministrativos e técnico-operacionais. A partir de 1998, o Controle Social vem se fortalecendo através de decisões e encaminhamentos mais concretos. Conclusões. Dentre outros aspectos, constata-se que a capacidade de deliberação precisa ser fortalecida através de capacitação com elementos técnico-político-administrativos, representatividade e fortalecimento da cidadania, divulgação das atividades dos Conselhos e maior articulação entre os vários Conselhos e Fóruns do município.

\section{Palavras chaves:}
a. Conselhos de Saúde
b. Controle Social
c. Gestão Participativa 


\section{SUMMARY}

OLIVEIRA ML. Social Control and participatory management in Public Health - The experience of Management Health Councils from the Campo Grande/MS county 1994/2002. São Paulo; 2003. ( Doctoral Dissertation - Faculdade de Saúde Pública da USP]

Objective. The trajectory of the social participation in Brazil, evolved since the $60 \mathrm{~s}$, from labor and union movements to a legitime process through social councils. In the Public Health this participation was considered legal by the law number $8.142 / 90$. In the context this study aims to analyse the Social Control practice and the participatory management role of Health Unities Councils. Methodology. Case studies were conducted with 5 councils, having as main source the agendas, and having as referencial the current law, county documents and a document from ILPES/CLAPS (1975). Result.The councils were organized as boards with a coordinator, secretary, it is formed in pairs, fragile representation, monthly meetings, frequent substitutions. The meetings are orientated by an agenda, being shown the explicit demands toward epidemiology situations and health services. The decision process gives a significant percentage to the technical-political-administrative and technical operation. From 1998 on the Social Control is getting stronger through enabling procedures. Conclusion. It was stated that the decision capacity and the deliberation need to be strenghten with information through enabling with technical-political -administrative elements, representation and legitimized citizenship, the spreading of the activities of the Councils and greater joint between several Councils and County Foruns.

Key Words:
a. Councils Health
b. Social Control
c. Participatory Management 
1. INTRODUÇÃO 


\subsection{A PARTICIPAÇÃO E O CONTROLE SOCIAL: CONCEITOS E PERSPECTIVAS PARA O SISTEMA DE SAÚDE}

$\mathrm{Na}$ história política brasileira, o processo participativo é muito recente, por conta das ações ditatoriais presentes nos vários momentos sócio - políticos nacionais. Dirigida por forças conservadoras desde os primórdios da Primeira República (1889) até aos anos 70 , a população brasileira teve grandes dificuldades para avançar e conquistar espaços que lhe permitisse tomar parte nas decisões políticas, com exceção do direito ao voto. Tida como ignorante, mal informada, deseducada, foi alvo de fortes ações de paternalismo e clientelismo, o que contribuiu muito para se manter passiva frente a problemas cruciais como educação, saúde, violência urbana, meio ambiente, desemprego etc.

Para JACOBI (2000, p. 27),

o conceito de participação está permeado de contradições, não só pela sua relação com o poder público, mas também pela sua amplitude conceitual. (...) nem sempre são claras as diferenças entre participação citadina, participação social ou participação comunitária ou, ainda, participação popular.

Revisitando o conceito de participação, numa evolução no tempo, pode-se encontrar vários pesquisadores que vivenciaram o processo, se detiveram em estudá-la e analisá-la e contribuíram para a construção de um quadro teórico sobre a temática.

De acordo com PINTO (1982), a participação pode se dar de maneira simbólica, receptiva, ativa e real, entendidas como se segue:

Participação simbólica, quando a população é convocada a ser parte de associações, partidos ou outras formas de organização, legitimadas pelo Estado, tais como cooperativas, sindicatos. Chamamos a esta forma de participação simbólica, porque ela se dá simplesmente como inclusão, sem que o sujeito tome qualquer parte, ativa ou receptiva, na associação organizada. 
Participação receptiva refere-se ao fato de alguém ou grupo social receber um serviço do Estado, como quando um certo número de pessoas vai regularmente ao posto de saúde, para receber atenção médica.

Participação ativa, quando a população toma parte em uma ação ou conjunto de atividades decididas e propostas pelo Estado. Por exemplo, quando se diz que a população, através de um mutirão, construiu um posto de saúde.

Participação real, a que se identifica com as reivindicações da população para assumir parte das decisões sociais.

Para JACOBI (1992, p. 34), existem duas concepções de participação: “1) a visão da participação restrita e delimitada; e 2) a visão da participação plena, enquanto ação permeada por uma noção de conflito".

Quando se fala de participação dos cidadãos deve-se enfatizar que se trata de uma forma de intervenção na vida pública comum a motivação social concreta que se exerce de forma direta, e de um método de governo baseado num certo nivel de institucionalização das relaçðes Estado/sociedade civil.

A participação deve ser entendida como um processo continuado da democratização da vida municipal, cujos objetivos são: 1) promover a iniciativa a partir de programas especiais visando o desenvolvimento de objetivos de interesse coletivo; 2) reforçar o tecido associativo e ampliar sua capacidade técnica e administrativa, tornando as entidades competitivas; 3) desenvolver a participação na definição de programas $e$ projetos e na gestão dos serviços municipais (idem, p. 35).

\section{AROUCA $(1987$, p. 15) declarava como participação popular uma prática social}

(...) que supõe a participação das classes sociais, principalmente a dos trabalhadores do campo e da cidade, em todos os niveis de organização da sociedade, sendo que a mesma não se dá de forma difusa, mas organizada, devendo envolver associações, comites, fóruns, conselhos, sindicatos, partidos, movimentos, organizaçzes, dentre outros, nos diferentes niveis de organização do Estado e nas diferentes áreas de atuação. 
Para BORJA (1988 referido por JACOBI 2000, p. 28 ) "participação é, sobretudo, o encontro entre as instituições representativas, partidos e administração, por um lado, e os movimentos e organizações sociais, que existem independentemente dos partidos politicos e dos mecanismos participativos, por outro". Ainda, para este autor, seu objetivo é "facilitar, tornar mais direto e mais cotidiano o contato entre os cidadãos $e$ as diversas instituições do Estado, e possibilitar que estas levem mais em conta os interesses e opiniões daqueles antes de tomar decisões ou de executá-las".

Para VALLA (1989, p. 91), a participação era entendida como "participação politica das entidades representativas da sociedade civil em órgãos, agências ou serviços do Estado responsáveis pelas politicas públicas na área social".

Participação é um processo de conquista, em constante vir-a-ser e que se tem como uma ação inacabada. Não é dádiva, nem concessão e nem é preexistente. $O$ processo de participação envolve uma disputa pelo poder, mostra-se como outra forma de poder (DEMO, 1998 p. 18).

A participação social, para o Ministério da Saúde do Chile (s.d, V. 1 p. 5), foi assim definida

\footnotetext{
Está orientada a que las personas (ninõs, jóvenes y adultos) sus famílias, organizaciones y comunidades, sean y se sientan parte protagónica de la tarea de promover y mantener su salud, como componente básico de su bienestar. Su objetivo es desarrollar la capacidad de trabajo conjunto institución-comunidad organizada. Se busca que la comunidad pueda tomar parte o influir em las decisiones sobre los assusntos de salud que le afecta y pueda involucrarse en el análisis, planificación y promoción de la salud. Asi, las aciones em salud aportarán al mejoramiento de la calidad de vida y al desarrollo social (idem, p. 2).
}

O processo participativo se manifesta, de maneira mais evidente, através de movimentos sociais, diretamente na sociedade civil ou através de órgãos colegiados - os conselhos sociais e vai ganhando espaço político e administrativo nas instituições do aparelho estatal. Tais conselhos, principalmente, a partir dos anos 80 , começam a apresentar 
expressão nacional, naquelas áreas onde os atores envolvidos se mostraram com maior liderança e mais atuantes. Quando esta participação se apresenta de maneira organizada, desempenhada por atores cúmplices e compromissados com uma causa coletiva, com possibilidade de opinar, deliberar e intervir na coisa pública, poder-se-á alcançar o papel de controle social.

JACOBI (1992, p. 42) considerava que os espaços de controle social e instâncias de participação implantadas,

(...) representam a referência da inovação e da construção de novas identidades dos atores sociais envolvidos. Trata-se de uma participação ativa, ou, como expresso por Amélia Cohn, 'no sentido do direito do cidadão', onde o elemento diferenciador é a coresponsabilidade na formulação das politicas de saúde.

Para JACOBI (1992, p. 34), "O tema da participação está diretamente vinculado aos processos de democratização política e às dinâmicas de gestão descentralizada".

Esta participação social configurada, agora, em controle social, torna-se elemento indispensável para a gestão participativa, elemento integrante do processo de democratização do aparelho estatal. Este processo, no sistema de saúde pública, no Brasil, foi regulamentado através das Leis $8.080 / 90$ e 8.142/90, com a legalização dos Conselhos de Saúde.

El concepto de gestión participativa en salud, está referido a la necessidad de favorecer la participación de todos los integrantes de los equipos de salud-quienes proveen los servicios - en el planteamiento, tanto como en la posterior ejecución y evaluación de las propuestas de programas de salud destinados a la solución de los problemas de salud reconocidos por la población (MINISTÉRIO DE LA SLAUD, CHILE, s.d. V. III p. 8). 


\subsection{ANTECEDENTES HISTÓRICOS}

Procurando resgatar algumas informações históricas da nossa sociedade, delimitando momentos políticos, faço algumas considerações sobre participação em saúde pública a partir dos anos 60, pois demarca um período sócio-político importante para a busca e concretização de significativas políticas sociais.

\section{ANOS 60 - PERÍODO DITATORIAL: movimento operário e sindicatos}

Nos anos 50-60, os movimentos sociais estavam associados à luta de classes. Na perspectiva marxista, o conceito de movimento social se inseria na questão da reforma ou revolução (HOBSBAWN, 1970 referido por GOHN, 1995 p. 330) e tinham, como objeto, o movimento operário ou camponês, os sindicatos e os partidos políticos.

No Brasil, a mobilização da população era evidentemente difusa e o país caminhava para o cerceamento democrático. Havia obstáculos de índole social e política. $O$ cerceamento político impunha limites às manifestações sociais, mas paradoxalmente, aconteciam mudanças significativas no sistema de proteção social.

A participação era concebida dentro da perspectiva do movimento operário, o qual se projetava através das lutas sindicais e se dava quando a classe trabalhadora tivesse sido dirigida por um partido revolucionário. Os sindicatos se assumiam como representantes da força de trabalho. Os movimentos sociais fortes fora do campo sindical (e estes sob o controle do Estado) eram raros, contribuindo para que as respostas das demandas se dessem num contexto de clientelismo e num perfil político contraditório. De acordo com GOHN (1995, p. 30), "lutas sociais são partes constitutivas das sociedades humanas desde os primórdios da humanidade" e, no Brasil, tais movimentos ganhariam maior visibilidade a partir dos anos 60 . 
Em meados dos anos 60, sentia-se a tentativa de se aplicar reformas sociais. Sob o signo do Desenvolvimento de Comunidades - onde a participação governo-povo devesse ser para transformação social ${ }^{1}$, criava-se o BNH, Projeto Rondon, MOBRAL, CSUs na perspectiva de integração ${ }^{2}$ social. Para AMMANN (1978, p. 26), entendia-se como Desenvolvimento de Comunidades,

o processo através do qual o próprio povo participa do planejamento e da realização de programas que se destinam a elevar o padrão de suas vidas. Isto implica a colaboração indispensável entre os governos e o povo para tornar eficazes os esquemas de desenvolvimento vióveis e equilibrados.

Procurando legitimação política no pós-64, proclamava-se a participação que se enquadrava na seguinte moldura (idem, 1978 p. 161-165):

- Concebida com base numa microvisão local, onde as lideranças naturais e institucionais contribuem com os técnicos no estudo dos problemas locais na elaboração, execução e interpretação de programas de "melhoria de vida", isentos de reflexão e ação sobre as relações sociais de produção, de gestão, de distribuição de bens e serviços, dentre outros;

- Aloca a participação nas instâncias macrosocietárias e tem caráter reformista, mas omite as relações de dominação e o conflito "(...) é visto como problema tangencial e transitório a ser solucionado";

- Defendem politicas de integração; o desenvolvimento nacional deveria se articular com todas as instâncias do planejamento e de todas as organizações e grupos sociais. Ao Estado, porém, caberia promover, planejar e orientar o desenvolvimento. “(...) os programas de Desenvolvimento de Comunidade devem caminhar em perfeita sintonia com as diretrizes nacionais, e reduzem expressa e enfaticamente o conceito e a prática de participação (ou cooptação) à 'adesão aos planos de governo';

- A participação é um processo que se opera no contexto histórico e implica uma

\footnotetext{
${ }^{1}$ Transformação social: Quando a população participa de decisões e é permeada pela noção de desigualdade e conflito.

${ }^{2}$ Integração social: Políticas estimuladas pelo Estado para superar a marginalização, mas com exclusão da população no processo decisório.
} 
"expansão e redistribuição de oportunidades, criando as condições concretas para que o conjunto da população possa tomar parte ativa na responsabilidade social".

Tais estratégias foram utilizadas "(...) enquanto conduto de veiculação e sanção dos interesses e da ideologia dominante, inoculados nos modelos do desenvolvimento brasileiro" (idem, 1978 p. 161). Experiências pontuais do periodo populista (1945-64) revelam participação em rede associativa estimulada pelo poder público, "(...) num processo de construção de cidadania regulada".

Com tais caracteristicas, e de acordo com PINTO (1982), podemos rotular tal participação como participação ativa. Nesta conformação de participação, os atores população, técnicos e grupos sociais -, serviam-se para informar, mas não a deliberar; fazer o que outros planejavam e menos a participar do processo decisório. Omitindo-se o conflito ou tido como transitório, avolumavam-se as tensões. As ações e serviços continuavam na lógica de que a ordem social é decorrente de comandos superiores, sem discussão sobre os fatores determinantes dos problemas e necessidades sociais. Ao Estado interessava ainda o máximo de controle. Mas acredito que esta fase tenha tido seu grau de importância no cenário sócio-político nacional, pois que um processo de democracia se conquista com inúmeros limites e a questão do poder está presente nas mais variadas circunstâncias, ficando comprometida a relação Estado -população.

O final deste periodo foi marcado pelo cerceamento de muitos movimentos sociais, mantendo-se, alguns, nos porões das Universidades e nos movimentos eclesiais de base.

\section{ANOS 70 - ABERTURA DEMOCRÁTICA: movimentos de rua e novos sujeitos históricos}

De acordo com COSTA (1989, p. 49), nos anos 70 , a luta das classes trabalhadoras foi substituida pelas massas urbanas. Movimentos de bairro, reivindicando condições de moradia, água, luz e demais serviços públicos urbanos, constituíam-se em uma 
importante rede de troca de experiências e organização e acontecia de maneira mais marcante, através de quebra-quebras, depredações, movimentos de protesto através de manifestações "irracionais e anárquicas". Estas fontes de conflitos e tensões eram percebidas como fomentadoras de revoluções e atos considerados anômalos no contexto dos comportamentos coletivos vigentes. Eram vistos como "curto - circuitos" que expressavam anseios abafados, representando a ponta do iceberg das necessidades sociais de segmentos da populaçăo. Constituíram-se em momentos educativos na sociedade e contribuíram para fazer emergir uma nova cultura de enfrentamento das questões sociais com vistas a incorporar a população na gestão dos serviços. De acordo com AVRITZER (1994 referido por JACOBI 2000, p. 17,18),

atores sociais modernos e democráticos surgiram, adquirindo uma nova identidade democrática e passaram a pressionar o Estado e o sistema politico a se adaptarem a uma nova concepção acerca da moderna institucionalidade democrática.

Para JACOBI (2000, p. 17), estes atores sociais

criaram novos espaços e novas formas de participação e relacionamento com o poder público. Esses espaços construidos tanto pelos movimentos populares quanto pelas diversas instituições da sociedade civil que articulam alianças de resistência popular $e$ lutas pela conquista de direitos civis e sociais.(...) Ao gerarem novos elementos de conhecimento e cultura, muitos movimentos imprimiram sua marca e orientaram sua ação pela defesa de práticas pautadas pela sua autonomia, (...) transformando as carências do seu entorno em práticas reivindicatórias.

Algumas considerações analisam a necessidade do surgimento de interlocutores coletivos (grupos comunitários e movimentos sociais), ou seja, organizações populares com uma certa presença, no nível local, que tornem possivel uma participação ativa e representativa; devem existir num constante processo de interação entre Estado e cidadãos e com a ocupação de cargos políticos do município por parte de partidos ou indivíduos favoráveis à mesma (JACOBI, 1992 p. 34).

A alternativa legitimadora do Estado contemporâneo enquanto políticas integradoras, foi facilitada por um relativo afrouxamento do militarismo e pela necessidade de 
aumentar a eficiência administrativa e, mesmo, por mais anti-popular que tenha sido o Estado, via-se obrigado a algum tipo de aproximação com a população, não podendo mais ignorar as demandas por serviços. Para OFFE (1975, p. 135-6 referido por JACOBI 1989, p. 7), “(..) o sistema de poder busca essencialmente dirigir sua intervenção para mitigar as lutas sociais". As questões urbanas apareciam como conseqüência de que o governo não conseguia atender as necessidades crescentes em relação à reprodução da força de trabalho. Tais movimentos contribuiam para a emergência de novos ${ }^{3}$ sujeitos históricos e se caracterizavam por não serem institucionalizados, não apresentarem organizações formais de defesa econômica e de representação política diante do Estado e da elite dominante.

JACOBI (2000, p. 12) afirma que, neste periodo,

a noção de participação cidadã ganha importância, evidenciando a necessidade de arranjos institucionais que estimulem, desde a esfera estatal, a criação de canais de comunicação com a sociedade e permitindo que de alguma forma se amplie a esfera de engajamento dos cidadãos.

\section{ANOS 80 - NOVA REPÚBLICA: (re) conquistando direitos sociais}

Mantinha-se, no Brasil, “(...) a resistência a um Estado que ameaça os cidadãos”. Os anos 80 se caracterizaram por incorporar, com destaque, a temática dos movimentos sociais. Esse periodo apresenta novas problemáticas e novos cenários sócio - políticos: mulheres, crianças, índios, negros e pobres - formaram uma nova "força da periferia", realizando, de acordo com SCHERER-WARREN \& KRISCHKE, citado por COHN (1993), "uma revolução no cotidiano". Iniciava-se a discussão de um Estado democrático e como tal deveria incorporar os cidadãos. Para GOHN (1995, p. 301), "isso significa associar democracia politica à democracia social". Entende-se como reconstruir, capacitar o Estado de inteligência para captar demandas e necessidades

\footnotetext{
${ }^{3}$ Entend[ia]-se por "novo", nos movimentos sociais, a criação de pequenos espaços de prática social nos quais o tema do poder não é[ra] fundamental (EVERS, 1984, p. 13 referido por COSTA 1989, p. 51).
} 
sociais, transformando estas em direitos. Este processo exige um Estado com capacidade de governo, ou seja, "(..) ordenar as relaçôes entre sociedade civil organizada e as instituições políticas, com capacidade técnico-administrativa e de planejamento", devendo exigir práticas coletivas solidárias para sua solução.

Aquele Estado democrático que se iniciava nos anos 80 , caminhava no sentido de fortalecer reformas e mudanças nas questões sociais. Colocava-se como interlocutor das demandas dos movimentos e agente indutor das políticas que regulamentam a dinâmica da sociedade. Este Estado deveria ter capacidade de detectar necessidades e demandas sociais, "(...) um estado capaz de detectar necessidades de médio e longo prazos que garantam o desenvolvimento sustentado e maior justiça distributiva num tempo eticamente aceitável" (GOHN 1995, p.301). As desigualdades sociais terminam por evidenciar problemas coletivos, “(...) exigindo, portanto, práticas coletivas solidárias”.

Para JACOBI (2000 P. 12), "trata-se de pensar sobre a participação popular e sua relação com o fortalecimento de práticas políticas e de constituição de direitos que transcendem os processos eleitorais e seus impactos freqüentemente ambiguos e/ou contraditórios sobre a cidadania".

Uma nova concepção de sociedade civil construida nos anos 80 permitia a elaboração de um conceito mais ampliado de cidadania - individual e coletiva. Segundo TELLES (1994 referido por GOHN, 1995, p. 302), há o reconhecimento do outro, cria-se uma nova linguagem decorrente de novas regras de contratualidade social. $\mathrm{O}$ conflito social passava a ser reconhecido, posto agora nas pautas de negociação. Para JACOBI (2000, p. 12, 18)

é na década de 1980 que a participação cidadã se torna instrumento para um potencial aprofundamento da democracia, (...) as interaçð̃es dos movimentos com os órgãos públicos tornam-se cada vez mais complexas, (...) permitindo a construção de novos padrões de valores [transformando] a feição dos movimentos ... O Estado não mais vê os movimentos somente como seus adversários, mas legitima suas reivindicações e as inscreve no campo dos direitos. 
Este processo ganhava uma roupagem democrática ao incluir atores com diferentes papéis sociais. A sociedade foi criando instâncias de representação direta que remetem às demandas sociais sobre o Estado. Para GENRO \& GENOÍNO (1995, p. 22), "tratase de agregar, processualmente, à democracia direta, participativa, que valorizam o cidadão com iniciativa - uma livre iniciativa da cidadania capaz de revalorizar a cena politica".

Este processo permitiu aos movimentos não só exercerem pressão sobre a arena política, como também ampliar seu espaço de inserção através, inclusive, da expansão de seu potencial participativo em Conselhos e demais formas específicas de representação (JACOBI 2000, p. 19). Aquela participação popular, através dos movimentos sociais urbanos, se reveste de características próprias daquele momento histórico através de práticas coletivas de negociação institucionalizadas com um certo poder de influência nas decisões, passando a ser entendido como controle social.

\section{INSTITUCIONALIZAÇÃO DA PARTICIPAÇÃO SOCIAL}

O regime político brasileiro avançava para o fortalecimento da democracia. Com a abertura democrática, em meados dos anos 80 , o setor saúde experimentava o enriquecimento da prática do planejamento, através das Ações Integradas de Saúde (AIS), quando se implementava maior participação técnica, e os debates sobre os determinantes da saúde e da doença, uso dos serviços, programação das ações, ganhavam uma outra lógica. O planejamento passava a ser desenhado com aspectos de descentralização e participação. Dois quesitos se tornavam imprescindiveis: o fortalecimento do setor social e a sociedade civil organizada. As comissões - CIPLAN, CIS, CRIS, CLIS ou CIMS - estimulavam o avanço do processo de democratização e racionalização dentro dos serviços em curso e, por conseqüência, da municipalização.

Neste novo cenário as questões de gestão dos serviços de saúde pública passavam a ser percebidas na ótica participativa, onde a população organizada passaria a ocupar espaços para debates e questionamentos. Mas como operacionalizar tal proposta numa 
sociedade marcada por clientelismo, paternalismo e por barreiras e obstáculos aparentemente irremoviveis?

A caminhada começava por uma trilha virtualmente desenhada, construída em cima de experiências acumuladas no cotidiano dos atores sanitários de então e se propunham a avançar, progressivamente, no fortalecimento da cidadania e na conquista de direitos sócio-sanitários e se movia no rumo de uma utopia - o combustível da máquina social ao implementar e transformar em justiça social os direitos sociais que, ora, passavam a ser assegurados.

O processo de participação em saúde pública caminhava, no final da década de 80 , no Brasil, para o processo de institucionalização da participação da sociedade civil junto ao aparato estatal através dos Conselhos de Saúde e das Conferências de Saúde, desejada e reivindicada pelo movimento da Reforma Sanitária dos anos 70. As experiências anteriores isoladas, como o caso do Movimento de Saúde da Zona Leste de São Paulo/SP, emprestava um modelo, e esta participação continuava se construindo lentamente no cenário nacional.

No estado de São Paulo, em substituição às AIS, ao assinar o convênio Sistema Único e Descentralizado de Saúde - SUDS, o governo de São Paulo manteve as Comissões Interinstitucionais como órgãos representativos, mas em relação aos Conselhos, "(...) assinou um decreto ratificando-os, porém, limitando seu âmbito de atuação" (WESRPHAL 1992, p.37).

No nivel nacional, embora de maneira obscura, acenava-se a possibilidade de descentralização da gestão do setor público, com um planejamento ainda de recorte normativo, e este apresentando pouca eficácia para a gestão do setor público. Entretanto, propiciou o fortalecimento das instâncias interinstitucionais, desde o município até o nível estadual. Tal modelo "(...) tinha a pretensão de dar uma base técnica e objetiva ao processo de decisão política". No entanto, critérios políticos partidários prevaleceram sobre os técnicos. Neste periodo, os mecanismos gerenciais se 
mostravam inadequados, "como se a programação fosse condição necessária $e$ suficiente para superar conflitos e interesses encastelados no interior do aparelho do Estado" (CECÍLIO \& MEHRY 1992, p. 67-8). Esta modalidade de planejamento não servia como orientador dos investimentos e não contribuía para as mudanças efetivas na prática gerencial.

A $8^{\mathrm{a}}$ Conferência Nacional de Saúde (1986) abria-se à participação popular, onde delegados de todos os Estados, representantes dos mais variados municípios, tiveram a oportunidade de apresentar suas propostas sanitárias porque até então esta participação era somente técnica e política. Criava-se uma arena de debates onde o conflito, o poder e a dominação começavam a ser enfrentados nas relações entre os vários segmentos da sociedade. Ao final da Conferência a proposta da Reforma Sanitária foi apresentada ao primeiro governo democrático. A Constituinte de 1988 incorporou quase que na totalidade as propostas da $8^{\mathrm{a}} \mathrm{CNS}$ e, portanto, as propostas da Reforma Sanitária, criando o SUS, o qual foi regulamentado pela Lei 8080/90.

A $8^{\mathrm{a}} \mathrm{CNS} / 86$, ao defender as vantagens da descentralização - desconcentração e redistribuição de poder - permitiu postular a democratização dos serviços com a proposta do controle social da população sobre as ações de saúde oferecidas pelo Estado, entendida pelos políticos como "canais através dos quais a população possa exercer o direito de opinar $e$ de intervir no funcionamento dos serviços" (RADIS/FIOCRUZ, 1987), ou ainda, como participação da população organizada. Esta proposta foi uma das incorporadas no texto constitucional que instituiu o SUS.

A partir dai, o controle social passou a ser defendido e entendido como "um novo padrão de representatividade na construção, operação e gestão das políticas sociais, em especifico as de saúde" (WESTPHAL, 1992).

A expressão controle social, muitas vezes, pode dar a conotação de que existe um poder oprimindo uma população e que existe uma ação opressora, atuando de fora para dentro de uma população "(...) cuja finalidade é modelar o comportamento de todos pelos padrões de normalidade definidos pelos donos do poder (BRANDÃO, 1987 p. 22). 
Pode até haver uma situação similar nas diferentes modalidades de sociedade e em diferentes momentos sócio -políticos de uma população. Aliás, AMMANN (1991, p. 28) assim se expressa: "Em defesa dos interesses do capital e tentando manter um equilibrio de forças - por onde passam interesses das classes fundamentais - o Estado brasileiro expande sua teia de controle a, praticamente, a todos os espaços e momentos do cotidiano das classes trabalhadoras".

Para CARVALHO \& SANTOS (1995),

é fundamental também perceber que não é mais o Estado controlando a sociedade ou a sociedade controlando o Estado, mas um processo de interfaces de controle no qual, mesmo reconhecendo que muitas organizações fazem o papel colaboracionista nas politicas sociais, hoje temos uma sociedade, que, do ponto de vista do movimento sanitário, quer que o Estado e também os organismos não-governamentais tenham processos de controle social em condiçz̃es democráticas e transparentes.

O controle social se constitui “(...) como espaço de exercício do protagonismo de sujeitos democráticos populares, "devendo constituir-se em "(...) espaço político que põe em cena interesses, imaginários, representações (...) [e] espaço de criação de uma cultura política democrática. Este espaço é uma situação de partida e não, de chegada (SPOSATI \& LOBO 1992, p. 367, 373). É para o nivel local que as políticas de saúde pública iriam projetar suas propostas de avanços, encontrando terreno fértil para o fortalecimento da construção da democracia e da cidadania, numa aproximação governo-sociedade civil.

\section{ANOS 90 - PARTICIPAÇÃO SOCIAL INSTITUCIONALIZADA: Os Conselhos Sociais}

Remetendo-nos, ainda, à questão da força dos movimentos sociais COSTA $(1989$, p. 58) declara que "os movimentos sociais refluíram ou fracassaram, [e isto] porque foram delimitados no espaço e no tempo". Ainda para GOHN (1995, p. 321), a crise dos 
movimentos sociais se relaciona com o decréscimo da militância e da mobilização das ruas, com o próprio plano de interesses dos movimentos, pois alguns estão fechados em si próprios, não-permeáveis a críticas, condução de forma paternalista, dentre outros. $\mathrm{Ou}$ ainda, como para HARBER (referido por GOHN, 1995 p.322), "com a incapacidade de algumas lideranças para criar ou implementar politicas sociais, após ascenderem pelo voto a cargos de poder, levando a descrença popular" e para BAIARLE (1994, 15-16 referido por GOHN 1995, p. 322), a dificuldade dos próprios movimentos defenderem interesses grupais, haja vista a subjetividade individual. Apesar de lutas e reivindicações, os movimentos sociais não conseguiram o êxito almejado na realização de transformações e intervenções, pois que se mostraram em movimentos fragmentados. "Parece que as análises assumem a falta de organicidade - e o caráter volátil - dos movimentos sociais como um todo da natureza" (COSTA 1989, p. 50).

No entanto, em termos internacionais, conforme alguns críticos dos movimentos sociais, avançam com maior determinação, os movimentos internacionais, porque tem a capacidade de prever e antever resultados e isto interessa aos governos. "Ele [Estado] necessita de atores competentes e criativos, inovadores" (GOHN, 1995 p. 323).

GOHN $(1995$, p. 313, 318), defende a posição de que o Estado

(...) não mais precisa[va] dos movimentos para se legitimar como não-repressor ou aparentar ser democrático. (...) o cenário da correlação de forças se alterou e a ala do movimento popular não-combativo se ampliou. Essa ala passou a ter lugar privilegiado enquanto interlocutora nas politicas sociais.

Com a queda do muro de Berlim o mundo deixou de ser bipolar, surgindo o processo de globalização, aumento nos índices de desemprego, diminuição de lutas por direitos e a institucionalização do processo de participação social em saúde. $\mathrm{O}$ cenário dos anos 90 presenciava transformações econômicas e novas ênfases nas políticas sociais. $\mathrm{O}$ fenômeno da globalização permitia estimular o trabalhador a decodificar os fatos, as informações e as políticas, conduzindo a uma reflexão individual e coletiva que viesse contribuir para melhor se apropriar de seus direitos de democracia e cidadania. Tornava- 
se imperioso a retomada do desenvolvimento e a proteção social aos grupos sociais vulneráveis à situação econômica.

Os movimentos sociais, como atores, transitavam para movimentos enquanto forma cultura, jeito de ser. Enquanto nos anos 70-80, havia grandes movimentos, nos anos 90, estes movimentos estarão difusos. O que, realmente, importa é a nova cultura política gerada, as novas instituições e os novos quadros de pessoal. $O$ espaço ocupado pelos movimentos, agora, em grande parte, estaria institucionalizado em Conselhos e ONGs.

Estes "novos movimentos sociais" - passaram a compor um conjunto de movimentos caracterizados por um perfil mais sócio-cultural e se mobilizavam por condições que afetavam seu modo de vida (JACOBI, 1989 referido por BOGUS, 1997 p. 41) e apresentavam algumas caracteristicas: ampliavam as temáticas de reivindicação: movimentos de gênero, pacifistas, ecológicos e nacionalistas; tinham uma postura de hostilidade em relação ao Estado; deslocavam suas principais demandas para o aumento da qualidade e da quantidade de informação disponível, para os diferentes grupos da população; surgimento de grupos de pressão, de interesses e conflitos, cada vez mais autônomos, abrangentes e em nome das 'coletividades'; os conflitos não estão mais circunscritos à esfera da infra-estrutura da sociedade - relação entre capital e trabalho tendendo a aparecer em todos os domínios da vida social; os movimentos se associavam a reivindicações sociais em defesa de interesses específicos (direitos dos cidadãos em relação aos serviços preventivos e assistenciais de saúde) ou em busca de mudanças mais globais na sociedade (modo de desenvolvimento econômico e a gestão de governos); lutas urbanas voltadas para o consumo de bens e serviços; tais movimentos foram representados por Comunidades Eclesiais de Base, associações de bairro, movimento feminista e movimentos ambientalistas e, mais recentemente, os Fónuns dos Usuários e Trabalhadores de Saúde do SUS; poder integrador da solidariedade em detrimento do dinheiro e do poder na esfera do mundo da vida, exercido externamente por associações espontâneas organizadas na esfera pública dos espaços públicos autônomos e diretamente associada a sua legitimidade, valorizando-se mecanismos de deliberação coletiva (TOURAINE, 1989a, 1989b; ADORNO, 1992; JACOBI, 1989 a; 
MACHADO, 1995; HABERMAS, 1987; PINTO, 1996 referido por BOGUS, 1997 p. 39-44).

GIDDENS (1991 referido por GOHN 1995, p. 341) colocava que, na era da globalização, a participação em atividades coletivas será um fator decisivo na moderna sociedade industrial quando o trabalho multidisciplinar e de equipe poderá favorecer a criatividade e as inovações. Despede-se daquela liderança que dominava pela retórica e "que influenciavam suas bases por suas personalidades fortes e marcantes (...)". Busca-se aquele que procura se adaptar rapidamente às mudanças do cotidiano e que saiba encontrar rapidamente seu papel no novo cenário, orientando-se por uma utopia e que possa ser a construção de uma sociedade mais justa e igualitária.

Nesse periodo, passavam a considerar, nos debates institucionais, a necessidade de se incorporar variáveis sociais, econômicas e ambientais na priorização dos problemas e necessidades das comunidades e que as mesmas viessem ser contempladas na programação dos diferentes níveis da administração pública e dentro de um contexto histórico-social. Passa, então, a participação em saúde a assumir uma nova roupagem, pois atores de diferentes niveis da sociedade civil e política se voltam para problemáticas de interesse coletivo, culminando em um cenário multissocial, assumindo este envolvimento, na prática da saúde pública, uma performance de participação social.

A busca e a crença na possibilidade de se galgar a (re)democracia em sua plenitude, tendo-se como um dos quesitos a serem conquistados, o fortalecimento da participação social em saúde, permitiu à sociedade brasileira avançar para o momento da Assembléia Nacional Constituinte, cujo objetivo foi a construção da nova Constituição Brasileira, em 1988.

A Constituição Brasileira representa direitos possiveis de conquista, mas seu texto não garante sua imediata implementação. Mais do que legalidade, ela se apresenta como um "plano global normativo", endereçado ao Estado e à própria sociedade (CANOTILHO referido por TOJAL, 1998). Ali estão representados interesses de toda a sociedade. Há que se conflitar, lutar, buscar, conquistar, entremeio a interesses dos mais variados, 
desde sanitários até interesses que envolvem formas de produção, administração da coisa pública, gestão dos serviços, formas de financiamento, origem dos recursos, dentre outros. Existe uma grande distância entre a questão do direito constitucional e da justiça social. Nem tudo que é direito torna-se justo socialmente. A existência de uma Constituição, ainda que avançada, não é suficiente para que os direitos humanos sejam efetivamente respeitados e implementados, mesmo porque o Brasil ainda não ratificou sua adesão aos Pactos de Direitos Humanos, mas foram incorporados à Constituição Brasileira por influência da Constituição Portuguesa (TOJAL, 1998).

Há que se reivindicar, por canais competentes e de maneira formal, na maioria das vezes. E este caminho, o caminho da luta pela justiça, ainda não tem sido palmilhado devidamente pela população. Pouco se conhece sobre os instrumentos disponíveis aos cidadãos para reivindicar o que já se tem como direito adquirido. A Constituição assemelha-se a uma vitrine. É preciso transpor as barreiras para se tomar posse do objeto necessário. Para se transpor, existem meios legais que não são muito familiares à população, fazendo com que ela se perca no caminho deixando de alcançar a situação objetiva desejada.

\section{PARTICIPAÇÃO SOCIAL NAS QUESTÕES DE SAÚDE PÚBLICA: democratização}

A trajetória ascendente da democracia foi permeando os movimentos populares, permitindo e estimulando um processo participativo em questões sanitárias e contribuindo para que as políticas de saúde pública tomassem novos rumos. As questões sociais, econômicas, ambientais passavam a ser incorporadas nos debates e nas ações sanitárias, privilegiando o enfoque coletivo e as necessidades de grupos sociais. Tais questões já eram desenhadas e defendidas por entidades na América Latina desde os anos 50. Passaram a ser discutidos no Brasil nos anos 60, mas por um período curto, haja vista a intervenção militar de 64 . Os Anais da $3^{\mathrm{a}}$ Conferência Nacional de Saúde (CNS/1963), publicados no mesmo período dos Anais da $9^{a}$ CNS (1992), evidenciam 
uma política que defendia a descentralização da gestão e o processo de municipalização, conferindo maior poder decisório e deliberativo ao nível local.

Os debates iniciados na América Latina nos anos 50, com repercussão no Brasil, nos anos 60 , começavam a ser vislumbrados como passiveis de concretização em meados dos anos 70. Um tipo de participação nas questões sanitárias começava se dar de maneira regulada e limitada, e isto, acredito, por dois motivos: reduzida possibilidade de vivência da população na vida pública e necessidade do Estado em se abrir para as questões sociais, numa postura de interlocutor, como quesito básico para legitimação do poder estabelecido de então.

São Paulo dava seus primeiros passos já em 1969. Vale a pena lembrar aqui que, embora num contexto de política integradora, um ensaio de participação comunitária em órgãos colegiados, dentro do Sistema de Saúde do país, foi identificado na gestão de Walter Leser, secretário de saúde do estado de São Paulo, pelo decreto $N^{0} 52.182$, tendo como conselheiros, personalidades de instituições representativas para a Saúde Pública do estado de São Paulo - Associação Paulista de Medicina, Associação Paulista de Hospitais, Faculdade de Higiene e Saúde Pública. Este gesto determinou a criação de "Conselhos de Comunidade", "(...) com a finalidade de colaborar no desenvolvimento de programas de saúde, na área de abrangência da Unidade" (WESTPHAL, 1992, p. 36).

Tratava-se de um ato de concessão, haja vista o momento histórico em que acontecia, mas com certeza, um fato representativo e de avanço no cenário das políticas sanitárias do país. Este avanço pode se conformar na ótica de dois aspectos: "avanço da democracia em nossa sociedade, com a abertura para a presença de novos sujeitos democráticos nos debates e nas intervenções. $O$ outro, é o que chamamos de 'avanço civilizatório', com a sociedade definindo os padrões mínimos que ela quer garantir a cada um" (SPOSATI, s.d.).

O cenário político social na América Latina continuava - nos anos 70 - assistindo o agravamento da crise e o avanço dos movimentos sociais. Em 1972, tinha-se a 
aprovação do Plano Nacional das Américas, na terceira reunião especial de Ministros de Saúde. Reconhecia-se o direito à saúde dos povos e "enfatiza-se o papel do Estado na formulação de uma politica setorial e propõe-se incorporar a população na organização e execução das tarefas sanitárias: a planificação participativa" (URIBE s.d., p. 48). De acordo com GOHN (1995, p. 231), “(...) o pais assiste a um vigoroso movimento de setores da sociedade civil para a democratização da saúde, entendida como direito Universal garantido pelo Estado e sob controle público".

No cenário internacional, a Conferência de Alma-Ata (1978) advogava e criava compromissos com os países signatários no sentido de se implementar, fomentar e fortalecer a participação da população nas decisões coletivas pertinentes a assuntos coletivos de saúde. Estabeleceu que a população, para o ano 2000, deveria ter participação plena na condução dos serviços de saúde na sua comunidade.

É direito e dever dos povos participar individual e coletivamente no planejamento e na execução dos seus cuidados de saúde" (declaração IV).

Requerem e promovem a máxima autoconfiança e participação comunitária e individual no planejamento, organização, operação e controle dos cuidados primários de saúde, fazendo o mais pleno uso possivel de recursos disponíveis, locais, nacionais e outros, e para esse fim desenvolvem, através da educação apropriada, a capacidade de participação das comunidades (declaração VII, item 5).

As propostas de planificação participativa de ALMA-ATA (1978), das Resoluções da XXIII Conferência Mundial de Saúde (1974) e do Plano Nacional das Américas (1972) sobre a importância da participação comunitária permitiam vislumbrar a possibilidade de inserção da população na formulação, execução e acompanhamento e avaliação das ações e serviços de saúde, ou seja, a possibilidade de gestão participativa. A Reforma Sanitária defendida por atores da saúde pública no Brasil difundia doutrinas e princípios acreditados como elementos necessários para fortalecer a democracia, devolver o direito de cidadania e conquistar direitos sanitários já declarados na Carta de Direitos Humanos. 
A mobilização social que emergia no Brasil produzia militantes que desenhavam um sistema de saúde único e descentralizado, o que, dentre outras coisas, pudesse garantir a criação de espaços institucionais de participação da sociedade na gestão da saúde, com poder deliberativo e se constituindo em estratégia para democratizar o poder.

O direito à saúde, na expressão maior da Universalidade, não vinha sendo distribuído, no Brasil, de forma eqüitativa para a população e, então, um processo político em saúde foi deflagrado com vistas à busca e conquista de bens e serviços específicos através da Reforma Sanitária, permitindo contribuir para a reorganização do Sistema Nacional de Saúde, culminando com a criação do SUS, pela Constituição Brasileira (1988), e sua regulamentação em 1990 pela Lei 8080 .

\section{PARTICIPAÇÃO SOCIAL NO SUS}

O processo da descentralização da saúde nos anos 80 contribuiu para se reduzir a camisa de força, "(...) que tolhe a capacidade de resolver problemas (de cada equipe), além de limitar as iniciativas $e$ de diluir as responsabilidades profissionais dos vários segmentos envolvidos no processo de planejamento" (CECÍLIO \& MEHRY, 1992 p. 69).

O Art. 198 inciso III, da Constituição Federal de 1988 garantiu a participação da comunidade no Sistema Único de Saúde, como uma das diretrizes da organização da rede regionalizada e hierarquizada do sistema de saúde. A Lei 8080/90 - que regulamenta o SUS - afirma no Art. $7^{\circ}$, VIII: "participação da comunidade", em cumprimento ao Art. 198 da Constituição Brasileira. Na conformação política do SUS, os Distritos Sanitários passariam a ser instâncias descentralizadas técnico-políticoadministrativas - os Sistemas Locais de Saúde (SILOS). Nesta proposta, a participação social fora enfatizada como elemento essencial integrante do processo. A figura dos SILOS se desenhava como tática de descentralização com intento de acelerar mudanças nas práticas sanitárias, tendo-se nos conjuntos sociais a possibilidade de maior transparência das necessidades sócio-sanitárias e político-ambientais no intuito, não só 
de descentralizar os problemas, mas também as soluções, fomentando as intervenções com as comunidades (MORITA, s.d.).

As diretrizes do SUS, ao orientar para a participação da comunidade, culminaram na regulamentação dos Conselhos de Saúde nos níveis Nacional, Estadual e Municipal com atribuições consultivo, deliberativo e fiscalizador. A participação social se estabelecia na legalidade e com ação institucional (Lei 8.142/90).

Tal modelo de participação, a despeito das barreiras, se inseria no contexto do controle social em saúde, alicerçando o processo de gestão participativa em saúde, a serviço de uma gestão democrática, permitindo abertura de novos canais de comunicação, metodologias capazes de articular pessoas, lideranças, organizações e instituições. Esperava-se que tal controle social permitisse "(...) visualizar pontos de interesses comuns nos processos desenvolvidos pelos três níveis de gestão do sistema, o que (...) permite a articulação dos instrumentos utilizados pelos referidos processos (...)" (EVANGELISTA, 1994). Este controle social, se efetivo, exercitado dentro dos Conselhos de Saúde, poderá representar um estágio elevado da sociedade organizada, devendo definir políticas sociais e de saúde, inclusive, avaliando a qualidade dos serviços.

Legalmente, o Conselho de Saúde tem função ampla, quais sejam:

Em caráter permanente e deliberativo, órgão colegiado composto por representantes do governo, prestadores de serviço, profissionais de saúde e usuários, atua na formulação de estratégias e no controle da execução política de saúde na instância correspondente, inclusive nos aspectos econômico e financeiros, cujas decisões serão homologadas pelo chefe do poder legalmente constituido em cada esfera de governo" (Lei 8.142/90).

A Lei ${ }^{\circ} 8.142$ de 1990 é decorrente das mudanças constitucionais de 1988, com a criação do SUS e regulamenta a participação da população nos conselhos de saúde. Sua legalidade não garante sua efetivação, haja vista a necessidade de um tempo que permita se vivenciar e sentir os resultados de um processo que depende, dentre outros fatores, 
do acesso dos cidadãos à informação ${ }^{4}$, de uma cultura participativa nos mais variados segmentos da sociedade civil e política, mesmo porque ainda pesam sobre os ombros dos cidadãos brasileiros as dificuldades e entraves para viver a democracia que se nos apresenta novamente como possível em meados dos anos 80 , depois de duas décadas de autoritarismo. De acordo com declarações de WESTPHAL (1992, p. 90-93), representantes das direções de serviços de saúde afirmam que “(..) pelo fato de tratarse de uma relação que está se construindo, o processo é muito lento, e que as unidades descentralizadas têm poucos meios para desenvolver seu trabalho".

Ainda, de acordo com ROCHA (1998, p. 5-11), "estes conselhos seriam um espaço de exercicio da cidadania onde a população participaria através de suas entidades representativas, da formulação da política, no planejamento, na gestão, na execução $e$ na avaliação das políticas de saúde". Sua presença no município, de acordo com a NOB/93 deveria fortalecer o processo de descentralização, privilegiar a participação e o controle social e era requisito para o município habilitar-se para as gestões parcial e semi - plena. Hoje, na vigência da NOB/96, a presença efetiva do Conselho Municipal também se torna quesito para a habilitação nas Gestões Plena da Atenção Básica e Plena do Sistema Municipal.

“A validade das deliberações dos Conselhos tem a mesma qualidade de uma decisão parlamentar, judicial ou ato administrativo, na esfera de autonomia dos próprios Conselhos" (STANISCI, 1996 p. 83).

SPOSATI \& LOBO (1992, p. 375) advoga ainda que o Conselho "necessita ser institucionalizado a fim de constituir 'uma regularidade' no fluxo decisório da instituição. (...) necessita constituir um sujeito coletivo regular ou contímuo para poder influir na gestão e produção das políticas de saúde". Esta regularidade contribui para que a construção do espaço democrático seja efetivo, quando aqueles interlocutores clandestinos transformam-se em interlocutores oficiais, cuidando-se, todavia, para não se transformar em mais uma burocracia.

\footnotetext{
${ }^{4}$ Para JACOBI (1992, p. 35), a questão não é meramente informar, “(...) mas explicitar e tornar transparentes $e$ abertos os canais de negociação".
} 
Tal atuação institucionaliza-se em gestão participativa das ações e serviços de saúde, nos três níveis de poder, no intuito de permitir a construção de uma democratização da gestão, na possibilidade de reforçar alguns aspectos. Dentre eles e, de acordo com JACOBI (1992, p. 42), reforçar "a capacidade de critica e de intervenção dos setores populares através da sua inserção num processo pedagógico e informativo de base relacional [e] a capacidade de multiplicação e aproveitamento do potencial dos cidadãos no processo decisório e dentro de uma lógica não-cooptativa.

Esta ação de controle socializado ajuda a definir os problemas: aspectos médicos, culturais, sociais, econômicos, ambientais, dentre outros. Identificar estes fatores e saber quando comę̧ar a enfrentá-los, é ainda desafio para os gestores. WESTPHAL (1995, p. 47) afirma que "o espaço de participação se configura em arenas políticas no qual se desenvolvem cenários de confronto e linhas de solução para o conflito". "Não um confronto pela negação, mas sim, pela diferença de posição para, inclusive, construir um campo de negociação.

O espaço do controle social, ainda que institucionalizado, não pode ser meramente um espaço administrativo: tem que ser politico, porque precisa por em debate também interesses simbólicos, imaginários, representações. Esses espaços, na verdade, são situações de partida, e não de chegada (SPOSATI \& LOBO, s.d.).

A participação e não a postura opinativa - postura de "palpitação"- neste processo de controle social é que vai estimular o potencial dos indivíduos para serem protagonistas de sua própria história. Amplia sua consciência sanitária, permite que a rede de instituições do sistema de saúde se configure num lugar, efetivamente, resolutivo e inovador de novas práticas de saúde. Permite priorizar a prevenção, a promoção da saúde, humanizar a relação instituição-usuário, melhora a equidade no atendimento, contribui para reinventar a gestão social. Os indivíduos e grupos sociais se assumem como sujeitos sociais ao interagirem com o sistema de construção de novas metodologias e desenvolvem seu próprio modo de construir seu próprio projeto. De acordo com MATUS (referido por URIBE s.d., p. 47), "desenvolvem sua própria capacidade de governo". O impacto será maior quanto maior for a organização destes 
sujeitos sociais. SANTOS (1992, p. 60) afirma que "o estágio de uma cultura influencia o nivel de participação". Tal cultura gera um senso de responsabilidade e esta objetiva uma obrigação de responder por algo que a autora denomina de accountability e depende ou acompanha o avanço de igualdade, dignidade humana, participação e incorporação de sujeito ativo no processo. É preciso participar para se criar ambientes favoráveis (domicílio, trabalho, serviços de saúde, bairro etc.) (Carta de Ottawa/96).

Tendo como substrato teórico os conceitos e os antecedentes históricos anteriormente apresentados este estudo vai entender como

Participação social em Saúde um processo inclusivo de vários atores da sociedade civil - indivíduos, grupos sociais organizados, instituições e organizações sociais nos serviços estatais -, dotados de habilidades políticas e administrativas com vistas à intervenção na vida pública em prol de direitos e de usufrutos de bens e serviços na sociedade e na tarefa de promover a saúde da população.

Controle Social em Saúde uma Estratégia para democratizar o poder, um canal de manifestação da participação social regulada e institucionalizada, normalmente no aparelho de Estado, de caráter educativo, reivindicando direitos coletivos e interferindo nas práticas políticas nos aspectos técnicos, administrativos, ambientais e orçamentários através de deliberações e encaminhamentos das decisões referentes às necessidades identificadas pelos representantes legítimos com vistas ao fortalecimento da cidadania e à promoção da saúde; é a ferramenta para a consecução da gestão participativa, $e$

Gestão Participativa, é o gerenciamento das ações e práticas políticas do controle social resultante da institucionalização da participação social nas instituições de saúde através de planejamento dirigido para a solução de problemas de saúde de uma população. Ainda, o ato democrático de gerenciamento de ações e práticas políticas que favoreçam a participação de vários atores sociais institucionalizados, num cenário de conflitos, com capacidade de 
controle e intervenção nas políticas através de planejamento de Programas de Saúde, transformando utopias em realidade na busca da equidade nos serviços de saúde. É a legitimação da participação social institucionalizada e o canal para a efetivação do controle social.

\subsection{JUSTIFICATIVA}

No Congresso da REDE IDA/93, chegou-se a algumas conclusões sobre o movimento popular, a participação da comunidade no processo de construção do SUS, dentre elas: a participação social ainda representa um papel frágil, refletindo a cultura anterior da população. A participação varia e tem sido esporádica, atuando em órgãos representativos dentro de conselhos comitês. A garantia da maior participação da comunidade está na dependência do seu maior grau de organização. "É importante mais uma vez ressaltar que o grau de organização das comunidades varia ao longo do tempo e das mudanças sociais, no entanto, esta organização não se dá de forma sempre crescente, podendo involuir em certos momentos" (Rede Ida - Boletim, 1993, p. 3).

A NOB/96 regulamenta as ações e serviços do setor saúde. Dentre as exigências para habilitação dos municípios às modalidades de gestão, a criação e funcionamento dos conselhos de saúde tem se mostrado como quesito básico. Entretanto, tais conselhos ainda estão longe de exercerem seu real papel. De acordo com a literatura, vêem se prestando mais à concordância com os orçamentos, numa situação de cooptação, do que a analisar, discutir e deliberar sobre as condições de saúde de sua área de abrangência, até porque existe um grande despreparo técnico-científico dos conselheiros.

(...) o processo de democratização não se apresenta do mesmo modo em cada um dos municipios. Permanece a luta pela constituição dos conselhos, pela legitimidade, como da representação popular, pela discussão de sua formação paritária entre população, trabalhadores de saúde e dirigentes SPOSATI (1992, p. 366).

No material da Oficina Pedagógica para Conselhos Gestores realizada em Campo 
Grande/M.S (2002, p. 4), assim está declarado sobre a legitimidade:

\begin{abstract}
A LEGITIMIDADE, por sua vez, se baseia no respaldo politico da sociedade, incluindo as bases dos conselheiros. A LEGITIMIDADE é a condição que um conselheiro, ou mesmo uma decisão adquire quando verdadeiramente representa as idéias de um grupo ou de toda a sociedade. Um conselho ou conselheiro que tenha legitimidade é um conselho ou conselheiro que tem apoio, o consentimento e a confiança da sociedade ou do segmento que representa.
\end{abstract}

A legitimidade é a condição que uma decisão ou mesmo um conselheiro adquire, quando sabemos que ele verdadeiramente representa as idéias de um grupo ou de toda a sociedade (REIS 2001, p. 132).

Orientada pelas idéias e conceitos, anteriormente, apresentados e, na qualidade de docente e profissional de saúde pública do Mato Grosso do Sul, sinto o interesse em conhecer o funcionamento dos conselhos gestores de Unidades de Saúde, haja vista uma politica que orienta para tal prática; os conflitos/barreiras e as alternativas que vêm se construindo na solução dos problemas sanitários; o desejo de trazer um conhecimento sobre a questão do controle social no nível de conselhos gestores de Unidades de Saúde e a possibilidade de contribuir nas políticas locais de saúde de Campo Grande/M.S.

Tendo-se a Lei $\mathrm{N}^{\circ} 8.142 / 90$ por referência, considerando-se a importância da gestão participativa em saúde em nível local, a relevância do tema face às políticas coletivas de promoção da saúde, a legalidade da representação e da participação social nas questões de politicas de saúde, coloco como QUESTÕES PARA REFLEXÃo DESTE ESTUDO: De que modo vem se dando a prática do controle social em saúde pública no contexto da gestão participativa no nível de conselhos gestores de Unidades de Saúde de Urgência/Emergência em Campo GrandeM.S? Os Conselhos vêm conseguindo, efetivamente, ser gestores das politicas de saude? Quais os avanços e os principais entraves estruturais, técnicos, politicos e sociais para a consecução do controle social? É possivel realizar a gestão participativa com a atual performance dos conselheiros e do Sistema de Saúde do pais? Como funciona politicamente o CG e qual a contribuição do CG para o planejamento em saúde? 
2. OBJETIVOS 


\subsection{OBJETTVO GERAL}

Conhecer e analisar a dinâmica, a prática do controle social exercida pelos atores sociais e vivenciada nas Unidades de Saúde de Urgência e Emergência em Campo Grande/M.S e sua influência na definição das políticas de saúde pública no município.

\subsection{OBJETIVOS ESPECÍFICOS:}

a) Identificar a organização e representatividade dos Conselhos Gestores;

b) Descrever a prática de atuação dos conselhos e sua capacidade de exercer a função deliberativa;

c) Identificar e analisar as decisões tomadas pelo Conselho Gestor no contexto da gestão participativa, no âmbito das Unidades de Saúde de Urgência - Emergência;

d) Verificar influências na implementação das políticas de saúde no município de Campo Grande/M.S e no âmbito do estado do Mato Grosso do Sul. 
3. METODOLOGIA 


\subsection{OBJETO DE ESTUDO}

O objeto de estudo é a dinâmica de funcionamento de Conselhos Gestores de Saúde de Centros Regionais de Saúde (Unidades de Urgência e Emergência ou, ainda, Unidades 24 h.) e sua influência no controle e execução das políticas de saúde pública no municipio de Campo Grande/M.S.

\subsection{REFERENCIAL DE ANÁLISE}

As demandas dos Conselhos foram agrupadas e analisadas tendo como molde a Sintese para Tipos de Diagnóstico de Saúde de TESTA (1981 referido por SÁ, 1992, p. 43-44), tendo como variáveis destas demandas: as queixas/reclamações, as reivindicações/sugestões e as decisões/deliberações e encaminhamentos. Mário Testa propõe os elementos para cada tipo de diagnóstico:

\section{a. ADMINISTRATIVO}

- estado de saúde (expressão de aspectos biológicos da população): morbidade, mortalidade, natalidade, população subdividida por sexo, idade e (eventualmente) macro-localização (urbana, rural, regiões). Os indicadores são TAXAS - tendo no numerador $0 \mathrm{n}^{\circ}$ de doentes, óbitos ou nascidos, e no denominador a população por sexo, idade ou macrolocalização.

- Situação epidemiológica (modelo de causalidade centrado em uma interpretação biológico-ecológica dos processos saúde/doença): - agentes, hospedeiros, vetores; algumas condições ambientais (p. ex.: água e lixo); - o "social" como agregado (um dado a mais), subsidiário na explicação; - indicadores: referidos a subconjuntos da população imunes ou expostos a riscos.

- Serviços de saúde (verificação da eficácia, eficiência e cobertura dos serviços): serviços e programas desenvolvidos (para cada programa); - estudo dos recursos (organização ou função de produção, quantidade, custo); - da produção de atividades e da produtividade.

- Setor saúde (análise da organização do setor com base no enfoque sistêmico): instituiçōes componentes do sistema; - o que consomem (recursos a elas destinados/'entradas"); - o que produzem ("saidas"/ações de saúde); - relações (funcionais) entre instituições. 


\section{b. ESTRATÉGICO}

- estado de saúde (expressão da distribuição de poder na sociedade): - categorias que destaquem diferenças de saúde entre distintos grupos sociais; - avaliação não só quantitativa, mas qualitativa; INDICADORES: numeradores e/ou denominadores das taxas definidos não só por critérios biológicos, mas econômico-sociais, expressando diferenças entre grupos.

- situação epidemiológica (modelo de causalidade centrado em uma interpretação social dos processos saúde/doença (mudança de paradigma): categorias de análise: processo de trabalho, modo de produção; classe social; circulação e distribuição de mercadorias, bens ou serviços; produção e reprodução da força de trabalho...; processos saúde-doença como parte própria e indissolúvel do funcionamento social.

- serviços de saúde (poder técnico como categoria básica): - análise das disputas cotidianas sobre o quê fazer e como fazer; - identificação da rede de micro poderes nos serviços, das estratégias de hegemonia do pólo dominante e respostas do pólo dominado; - relação dessas disputas com a luta pelo Poder na sociedade; - eficácia e eficiência politica.

- setor saúde (poder administrativo como categoria básica): - estrutura de poder sobre o setor (incluindo articulação com o social global), que não se encontra necessariamente no setor; - financiamento = principal modalidade de poder administrativo/mediação entre poder e organização setorial; - formas de financiamento, origem e destinação social dos recursos, controle sobre os recursos.

\section{c. IDEOLÓGICO}

- Condição de legitimidade das propostas em saúde: coerência entre propostas, "ideologia de saúde" e "ideologia social global";

- Identificação, no setor e na sociedade, da "visão de mundo" dos atores sociais;

- Quais grupos sustentam quais sistemas sobre o processo saúde-doença: biológico, ecológico, social;

- Identificação dos sistemas de idéias que prevalecem;

- Explicitação do valor simbólico manipulativo de determinadas propostas ou idéias (instrumentos de manipulação);

- Identificação - em função das idéias que sustentam - de aliados, aliados potenciais e 
adversários, para melhor orientar as estratégias.

Entretanto, tais demandas são apresentadas através de um recorte simplificado da Síntese para Tipos de Diagnóstico de Saúde de TESTA, usado como caminho para categorização das referidas demandas dos CG estudados, sem distingui-las em Diagnóstico Administrativo e Estratégico. As categorias de Testa utilizadas neste estudo e os respectivos elementos são:

- Situação epidemiológica: agentes, hospedeiros, vetores; algumas condições ambientais (p. ex.: água e lixo); - o "social" como agregado (um dado a mais), subsidiário na explicação; - indicadores: referidos a subconjuntos da população imunes ou expostos a riscos. Ainda, processo de trabalho, modo de produção; classe social; circulação e distribuição de mercadorias, bens ou serviços; produção e reprodução da força de trabalho...; processos saúde-doença como parte própria e indissolúvel do funcionamento social.

- Serviços de saúde: estudo dos recursos (organização ou função de produção, quantidade, custo); - da produção de atividades e da produtividade. Ainda, análise das disputas cotidianas sobre o quê fazer e como fazer; - identificação da rede de micro poderes nos serviços, das estratégias de hegemonia do pólo dominante e respostas do pólo dominado; - relação dessas disputas com a luta pelo Poder na sociedade; - eficácia e eficiência política.

- Setor saúde: instituições componentes do sistema; - o que consomem (recursos a elas destinados/"entradas"); - o que produzem ("saídas"/ações de saúde); - relações (funcionais) entre instituições e, ainda, estrutura de poder sobre o setor (incluindo articulação com o social global), que não se encontra necessariamente no setor; financiamento $=$ principal modalidade de poder administrativo/mediação entre poder e organização setorial; - formas de financiamento, origem e destinação social dos recursos, controle sobre os recursos.

Vale a pena esclarecer que o uso das categorias acima indicadas não significou avançar para uma análise detalhada das questões, procedimentos e técnicas de planejamento 
estratégico em saúde, mas acredito ser uma forma didática de apresentação das problemáticas dos CG para melhor visualização das demandas apresentadas, discutidas e reivindicadas nas reuniões dos Conselhos-sujeitos deste estudo. As queixas/reivindicações aqui apresentadas devem ser entendidas como necessidades sociais e técnicas sentidas pelos conselheiros, ponto de partida para as decisõesdeliberações-encaminhamentos necessários e/ou viáveis/factíveis.

Necessário, também, é analisar, de acordo com os objetivos propostos, a prática do controle social e sua influência nas definições das políticas de saúde pública no contexto da gestão participativa no cenário das políticas do SUS no município de Campo Grande/M.S, como resposta às queixas e reivindicações dos Conselhos estudados. Para esta análise orientei-me pelo referencial do documento FORMULACIÓN DE POLITICAS DE SALUD do ILPES/CLAPS/OPS (OMS, 1975). Este referencial inclui um complexo de três grandes componentes, considerados básicos para a tomada de decisões, quais sejam: a. componente político; b. componente técnico-administrativo; e, c. componente técnico-operacional.

Além dos canais formais e informais de comunicação com a área do poder real e com todo ambiente social, são reconhecidos, no aparato formal do Estado, três componentes funcionalmente diferenciados: o político propriamente dito - o fazer, o decidir -, constituído pelas autoridades com poderes de decisão; o técnico-administrativo, de responsabilidade fundamental das ações de assessoria (corpo técnico administrativo) e de informação, e o técnico-operacional, responsável pela implementação e execução das decisões tomadas, a tradução do político, a execução das decisões políticas (IDEM, p. 13,30). O processamento de uma demanda política qualquer deveria abranger sempre estes três componentes.

Este documento reconhece o conflito social como ponto de partida do processo de geração e da implementação de políticas de saúde (PUPO 1999, p. 23). De acordo com WESTPHAL (1992, apud PUPO 1999, p. 23) o conflito supõe necessidades insatisfeitas, individuais e coletivas (calcadas na desigual distribuição de bens e serviços 
de saúde), as quais são processadas - pelos grupos de pressão ou pelo próprio Estado na forma de demandas políticas, finalmente institucionalizadas pela autoridade política.

POLÍTICAS são processos sociais que conduzem à tomada e execução de decisões através das quais se adota e definem-se valores para toda a sociedade, devendo ser acatadas por todos. Tais decisões, de monopólio do Estado - poder formal, são produtos de processos políticos, intervindo e influindo, como partícipes, indivíduos, grupos, classes sociais, conformando-se o poder real. Pode-se limitar o político às ações e relações específicas vinculadas à geração, tomada e controle de tais decisões (ILPES/CLAPS 1975; p. 5-6).

É preciso ressaltar que a categorização em político, administrativo e operacional foi feita pela minha percepção, mesmo porque o documento não categoriza os elementos de acordo com cada componente do processo decisório.

\subsection{TIPO DE ESTUDO}

A pesquisa é de caráter qualitativo e se orientou pela técnica de Estudo de Caso. A pesquisa qualitativa é socialmente construída, enfatiza as interações, com técnicas de análise indutivas, permite interação com os sujeitos da pesquisa, considera a subjetividade dos sujeitos, permite a compreensão da dinâmica interna de programas e atividades, e, de acordo com MINAYO (1993, p. 10),

As Metodologias de Pesquisa Qualitativa [são] entendidas como aquelas capazes de incorporar a questão do 'Significado e da Intencionalidade' como inerentes aos atos, às relações, e às estruturas sociais, sendo essas últimas tomadas tanto no seu advento quanto na sua transformação, como construçðes humanas significativas.

As metodologias qualitativas, passaram a garantir maior liberdade ao pesquisador, para captar a dinâmica e profundidade de relações presentes em um grupo pesquisado (LUDGE \& ANDRÉ, 1986 referido por WESTPHAL, 1992). 
Estudo de caso é a pesquisa sobre um determinado individuo, familia, grupo ou comunidade para examinar aspectos variados de sua vida (CERVO \& BERVIAN, 2000, p. 57). Ainda, para TRIPODI (1984, p. 79), a técnica de estudo de casos tem como objetivo a descrição detalhada de um programa social à medida que este se desenrola em seu processo de desenvolvimento.

O estudo de caso permite identificar particularidades próprias do objeto de estudo descrito e analisado como um fenômeno específico, podendo evidenciar características próprias dado o contexto histórico de sua origem e desenvolvimento.

A pesquisadora, os conselheiros de saúde dos Conselhos de Unidades pesquisados, técnicos da Secretaria de Saúde do Município de Campo Grande/M.S, agentes de saúde do PACS, dentre outros, estiveram envolvidos no processo de construção das informações deste estudo numa relação interativa, com vistas a uma maior aproximação do objeto de estudo.

O estudo foi desenvolvido em dois grandes momentos:

$1^{\circ}$ Momento: exploratório - momento de captar as questões gerais e especificas da criação e organização dos conselhos gestores, de caráter descritivo, através da delimitação do problema, definição dos objetivos, construção do marco teórico conceitual, construção dos instrumentos de coleta de dados e do levantamento e descrição dos dados através de uma investigação histórica, subsidiada por documentos dos Conselhos - Atas e Oficios encaminhados; momento este de se verificar a situação de conjuntura, procurando estar atento ao fato de que a identificação da realidade é complexa e mutante, devendo-se considerar criticamente o elemento político e de poder (AZEVEDO, 1992, p. 132).

$2^{\circ}$ Momento: analitico/interpretativo - feito, parcialmente, paralelo à coleta de dados dos documentos, mas, principalmente, ao final da composição dos resultados conformando uma análise final. Momento de identificar e explicar - através da análise dos dados documentais, entrevistas e observações de reuniões -, os porquês dos fatos. Ainda, vislumbrar caminhos alternativos, os quais possam contribuir para dar subsídios 
à construção de uma proposição transformadora que estimule uma melhor desenvoltura da gestão participativa em saúde, no contexto dos conselhos gestores das Unidades estudadas, com vistas a instrumentalizar os conselheiros para tomadas de decisões mais eficazes.

\subsection{UNIVERSO E AMOSTRAGEM}

Existem 9 Conselhos de Unidades de Urgência e Emergência - os Centros Regionais de Saúde (CRS) e 12 Conselhos de Unidades de Referência para o município de Campo Grande/M.S. Considerando o fator tempo disponivel para a pesquisa, os recursos viabilizados e capacidade de análise dentro do tempo efetivo para o estudo, coletei os dados em 4 Conselhos Gestores de Unidades de Saúde de Urgência e Emergência, representando um Conselho de cada Distrito Sanitário (norte, sul, leste, oeste) da área urbana do município de Campo Grande/M.S, e um Conselho Gestor de Unidade de Referência para o município de Campo Grande/M.S, segundo os seguintes critérios:

- tamanho da área de abrangência da Unidade de Saúde;

- volume de atividades desenvolvidas;

- corpo de recursos humanos;

- tempo de funcionamento (Conselho com mais de um ano);

- funcionamento do Conselho à época da coleta dos dados;

- grau de complexidade da Unidade;

- questões sócio-econômicas.

Os Conselhos escolhidos foram:

DISTRITO NORTE: Conselho do CRS “Dr. Güinter Hans” - Bairro Nova Bahia.

DISTRITO SUL: Conselho do CRS “Dr. João Rosa Pires” - Bairro Aero Rancho.

DISTRITO LESTE: Conselho do CRS "Dr. Marcilio Oliveira Lima"-B. Moreninha III.

DISTRITO OESTE: Conselho do CRS "Dr. José Geraldo Abuhassan" - Vila Almeida.

UNIDADE DE REFERÊNCIA: Centro de Especialidades Médicas - CEM. 


\subsection{FONTES DE DADOS}

\section{A. Documentos:}

1. Legislação, Regimentos dos Conselhos de Unidades de Saúde de Campo Grande/M.S;

2. Livros de Atas das reuniões dos conselhos gestores estudados;

3. Oficios e documentos de deliberações dos Conselhos Gestores;

4. Documentos da Secretaria Municipal de Saúde de Campo Grande/M.S;

5. Diário Oficial do Município de Campo Grande.

Nos documentos verifiquei os temas abordados, a relevância dos temas para o funcionamento dos Conselhos e das Unidades e para as políticas de saúde, processo de discussão e participação nas deliberações. Ainda, se há processo de acompanhamento das deliberações; reflexo das deliberações no funcionamento das Unidades de Saúde e relações e implicações com os Conselhos Municipal e Estadual. Os documentos são parte do real podendo me permitir examinar as diretrizes e normas oficiais. Neles pude perceber as problemáticas que estavam em jogo.

\section{B. Observação:}

Observação de reuniões dos Conselhos das Unidades de Saúde, Conselho Municipal e do Fórum dos Usuários do SUS. Esta ação me permitiu uma inserção na rotina das reuniões, numa tentativa de perceber melhor os comportamentos, as motivações e aspirações dos conselheiros. Para BRANDÃo (1987, p. 27), “A inserção é o processo pelo qual o pesquisador procura atenuar a distância que o separa do grupo social com quem pretende trabalhar".

A observação é sempre uma ferramenta auxiliar para se captar mensagens silenciosas e não verbais que possam estar permeando cada momento. Neste momento pude verificar quem fala, como fala, para quem fala (direta/indiretamente), por quem fala (direta/indiretamente), valores e idéias defendidas (representação do real), questionando, inclusive, alguma idéia/fato mal compreendido no momento. Durante este processo pude indagar a um e outro conselheiro e, inclusive, para agentes do PACS questões não muito claras sentidas no momento das reuniões. 


\section{Entrevistas:}

As entrevistas se justificam pela oportunidade de melhor se perceber os movimentos, a forma de atuação dos segmentos dos conselhos gestores, etc. Este diálogo pode estimular a livre expressão do conselheiro, ampliando o campo do discurso incluindo fatos, opiniões, devaneios, projetos, impressões, reticências, inflexões, hesitações, pausas e silêncios, etc. no intuito de se perceber as contradições e incoerências entre o falar e o agir.

Foram entrevistadas todas as gerentes das Unidades, as coordenadoras dos CG estudados, a chefe do setor do Controle Social da SESAU, secretária do CMS e Secretária de Saúde. Ainda, com demais atores como os responsáveis pelo Serviço de Apoio ao Controle Social da Secretaria Municipal de Saúde de Campo Grande/M.S, Secretária de Saúde do municipio e alguns outros profissionais que se articulam com as questões do controle social no município.

D. Questionário: com questões abertas e com conselheiros atuais e conhecedores da história deste processo, identificados durante o mesmo, feitas à posteriori da análise dos documentos e das observações e das entrevistas, no intuito de captar questões pouco elucidadas. Foram enviados 40 questionários (8 para cada CG). Foram devolvidos 18 , dos quais, 14 respondidos por usuários, 3 por prestadores de serviços e 1 por trabalhador. Um dos CG estudados não devolveu nenhum questionário. A coordenadora, somente, preencheu seu nome e devolveu.

\section{E. Levantamentos e revisão de estudos:}

Pesquisas e trabalhos sobre a Reforma Sanitária, Conferências Municipais e Nacionais de Saúde, NOB/96, Plano Diretor da Reforma Administrativa do Estado, Relatórios sobre Encontros de Conselheiros no município de Campo Grande/M.S, e bibliografia pertinente da área, numa busca paralela às demais etapas.

\subsection{INSTRUMENTOS DE COLETA DE DADOS}

1. Formulário para coleta de dados das Atas de reuniões;

2. Roteiro de Observação; 
3. Roteiro de entrevistas;

4. Questionário com perguntas abertas.

\subsection{ETAPAS DA COLETA DE DADOS}

O estudo se desenvolveu na seguinte ordem: etapa documental: descrição e análise das Atas e documentos pertinentes ao controle social em cada CG; observação de reuniões; entrevistas; questionário; tabulação dos dados; redação dos resultados e discussão parcial; análise e discussão final e Redação Final.

\subsection{PERÍODO DE ESTUdO}

O estudo foi desenvolvido a partir da criação de cada Conselho Gestor estudado, tendo em vista identificação e análise da evolução da sua organização (periodicidade das reuniões, composição e representatividade dos conselheiros), processo de trabalho, gestão participativa e capacidade deliberativa como expressão de um processo participativo interno no nivel das Unidades e nas suas relações com os Conselhos Municipal e Estadual de Saúde: Conselho do CRS "Dr. Güinter Hans" - Bairro Nova Bahia (1994); Conselho do CRS "Dr. João Rosa Pires” - Bairro Aero Rancho (1997); Conselho do CRS “Dr. Marcílio Oliveira Lima”-B. Moreninha III (1996); Conselho do CRS “Dr. José Geraldo Abuhassan" - Vila Almeida (1994); Centro de Especialidades Médicas - CEM (1999).

\subsection{QUESTÕES ÉTICAS ENVOLVIDAS NESTA PESQUISA}

O estudo foi pautado pelas recomendações da Res. $196 / 96$ do CNS/MS. O procedimento de observação nas reuniões dos Conselhos não foi gravado para voz e imagem. O Termo de Consentimento Livre e Esclarecido - TCLE, foi fornecido durante a etapa de observação.

Os procedimentos de observação não trouxeram nenhum comprometimento ou danos à dimensão física, moral, intelectual, cultura, espiritual ou social do entrevistado em nenhuma das fases da pesquisa ou decorrente dela, haja vista a proposta de se manter o anonimato (Res. 196/96, I.8). Algumas entrevistas foram gravadas em mini-cassete para se reduzir perdas de expressões e informações, sem identificação nominal do 
conselheiro e sem dizer a que Conselho pertencia. Tais entrevistas foram agendadas em horário e local conveniente para o entrevistado. Senti-me à vontade e preparada profissionalmente para realizar e conduzir tais procedimentos (Res. 196/96, III.3.h). A pesquisa não envolveu a comunidade diretamente, mas seus representantes. Meu papel foi, inicialmente, perguntar. Posteriormente, no momento da análise, tive suporte local para me ajudar a entender questões ligadas a aspectos culturais e sociais, dentre outros (Res. 196/96, II.3.L). Os sujeitos envolvidos e a comunidade que eles representavam tiveram o conhecimento dos resultados da pesquisa, através de Seminário. As orientações e proposições nasceram do grupo envolvido, enriquecidos pela pesquisadora e fundamentados, teoricamente, com bibliografias específicas (Res. 196/96, II.3.q).

A composição do texto final se faz enriquecido com os depoimentos, pinçados das Atas, documentos, questionário e entrevistas, onde algumas expressões - chaves importantes e necessárias à análise estão transcritas sob a forma itálico, procurando-se dar maior fidedignidade às demandas colocadas, e se constroem seguindo a linha do tempo, ou seja, as primeiras informações referem-se ao início do funcionamento do CG em questão e, as últimas, ao final do periodo de estudo, ou seja, dezembro de 2002. 
4. CARACTERIZAÇÃO DO MUNICÍPIO DE CAMPO GRANDE/M.S 
Campo Grande é um município com $8.118,4 \mathrm{Km} 2$, geograficamente localizado na região central de Mato Grosso do Sul, com altitude de 532 metros. Está situado sobre a Bacia Sedimentar do Paraná, com arcabouço geológico constituido pelas unidades geológicas Grupo São Bento - porção oeste do município (arenitos eólicos de idade jurássica recoberta por derrames basálticos ) e Grupo Bauru - porção centro-oeste do município (arenitos finos e médios). Aspectos do relevo planos e com classes de solo predominantes: latossolo vermelho escuro - textura arenosa - com grande capacidade de infiltração d'água superficial com pouca susceptibilidade a erosão; latossolo roxo: profundos, bem drenados - textura argilosa com grandes extensões na região oeste e noroeste do município; areias quartzosas: solos não hidromórficos, textura predominantemente compota por areia; solos litólicos: solos rasos - com textura média cascalhenta ou argila cascalhenta e é encontrado em pouca extensão na porção noroeste do município. Pertence aos domínios da região fitogeográfica do Cerrado com fisionomia diversificada; composição florística bastante heterogênea. $70 \%$ do município são áreas antrópicas ( atividades agro-pastoris, com plantio de culturas cíclicas e pastagens).

Possui clima mesotérmico úmido sem estiagem e tropical úmido (classificação de Koppen). Cerca de $75 \%$ das chuvas ocorre entre os meses de outubro e abril e o mês mais seco é agosto (EMBRAPA apud PLANURB, 2001)

A cidade de Campo Grande se caracteriza pela centralidade comercial e de serviços e por atividades comerciais intensificadas, também, ao longo das avenidas que são saídas da cidade e com acesso a bairros periféricos. A cidade possui uma taxa de urbanização de $98,84 \%$ (654.832 hab.), com predomínio de população feminina e razão de sexo de $94,71 \%$. Campo Grande detém $31,13 \%$ da população do estado, e vem apresentando baixos níveis de fecundidade, havendo redução no grupo de idade de 0 a 14 anos em oposição ao grupo de 15 a 64 anos e o de 65 anos e mais. De 1994 para 2000 vêm sendo reduzidas as taxas de natalidade, de mortalidade e mortalidade infantil. A partir de 1991 se começa a observar o declínio de correntes migratórias. 
Os estabelecimentos industriais instalados voltam-se para, aproximadamente, 25 ramos de atividades (FIEMS, 2000 referido PLANURB, 2001), num total de 3.583 estabelecimentos. Possui, ainda, 7.549 estabelecimentos comerciais, representando $33,90 \%$ do estado.

Possui um mercado municipal, 59 feiras livres - administradas pela Prefeitura, através da Secretaria Municipal de Controle Urbanistico - SEMUR. Em 2000 contribuiu com $52,42 \%$ do ICMS do estado. Oficialmente, $99 \%$ da população do município está servida por rede elétrica da ENERSUL. Desde 2001 se encontra em operação a rede de distribuição de gás natural que atende a termelétrica de Willian Arjona, com $80 \mathrm{MW}$ e consumo de $500 \mathrm{mil} \mathrm{m} 3 /$ dia de gás natural. A SANESUL é a empresa que administra a operação e manutenção das redes de água potável (reservação de $63.145 \mathrm{~m} 3$ ), com duas Estações de Tratamento de Água e 94\%, em 2000, de índice de abastecimento, e esgotamento sanitário - $366 \mathrm{Km}$ de rede ( $21 \%$ da população) e seis estações de tratamento de esgoto. Cerca de $46 \%$ das vias são pavimentadas (PLANURB, 2001).

O sistema de coleta de lixo domiciliar é realizado em $98 \%$ da área urbana, com exceção dos loteamentos clandestinos. O serviço é feito através de 19 veículos equipados com coletor compactador e recolhem em média 500 toneladas por dia, de 58 setores e 2 setores hospitalares. A coleta é feita todos os dias, na área central, e 3 vezes por semana, na periferia. O destino final desse lixo é o aterro sanitário.

O Sistema Integrado de Transportes - SIT, conta com 8 terminais transporte coletivo. O serviço de comunicação - rádio e televisão - é formado por dez emissoras de rádio e cinco de televisão; quatro jornais diários e 12 semanários e quatro revistas: Revista Destaque, Revista Executivo, Revista Metrópole e Revista O Palanque.

Em 2000, eram utilizadas 4.053 salas de aulas das 4.283 existentes. A Universidade Federal oferece 23 cursos de graduação; a Universidade Católica Dom Bosco - UCDB, 33 cursos; a Universidade para o Desenvolvimento do Pantanal - UNIDERP, 32.

O atendimento médico básico, em 2000 apresentava o seguinte cenário: 
TABELA 01 - Número de atendimentos médicos nos Distritos Sanitários de Campo Grande/M.S e CEM - 2000

\begin{tabular}{|c|l|l|l|l|l|}
\hline Atendimentos & D. Norte & D. Leste & D. Sul & D. Oeste & CEM \\
\hline $\begin{array}{c}\text { Consultas } \\
\text { médicas nas } \\
\text { Unidades de } \\
\text { saúde } \\
\text { municipais }\end{array}$ & 290.115 & 298.700 & 320.322 & 327.069 & \\
\hline AVEIANMs & 476.391 & 329.832 & 597.121 & 611.399 & \\
\hline $\begin{array}{c}\text { Consultas } \\
\text { odontológicas }\end{array}$ & 97.632 & 174.152 & 75.515 & 71.676 & \\
\hline
\end{tabular}

Fonte: Perfil sócio-econômico de Campo Grande/M.S - PLANURB, 2001

A SESAU realizou, neste mesmo ano, 92.955 exames especializados e 383.186 exames de patologia clinica. Existia, em 2000, 23 hospitais e clínicas com um total de 1.840 leitos.

O Distrito Norte tem 10 Unidades de Saúde; Distrito Sul, 8; Distrito Leste, 7; Distrito Oeste, 11 e SESAU, 10. Cada Distrito tem um Centro de Saúde na zona rural. Outros serviços da SESAU: farmácia central, serviço de verificação de óbito, DISK AIDS e DISK SAÚDE.

Tabela 02 - Indicadores de saúde - 2000 - Campo Grande/M.S

\begin{tabular}{|c|c|}
\hline Indicadores de saúde & \\
\hline Coeficiente de mortalidade geral (por 1000 hab.) & 4,71 \\
\hline Coeficiente de mortalidade (por 1000 nascidos vivos) & 15,94 \\
\hline Coeficiente de mortalidade materna (por 1000 nascidos vivos) & 30,89 \\
\hline Coeficiente de mortalidade neonatal (por 1000 nascidos vivos) & 9,11 \\
\hline Coeficiente de natimortalidade (por 1000 nascidos vivos) & 8,96 \\
\hline Coeficiente de natalidade & 19,46 \\
\hline Nascidos vivos & 13,110 \\
\hline Obitos (todas as idades e sexos) & 3.394 \\
\hline
\end{tabular}

Fonte: Perfil sócio-econômico de Campo Grande/M.S - PLANURB, 2001 
Nos anos $1999-200$, foram as seguintes as vacinas nas $1^{\mathrm{a}}$ e $2^{\mathrm{a}}$ etapas da campanha nacional de multivacinação:

Tabela 03 - Relação das $1^{\mathrm{a}}$ e $2^{\mathrm{a}}$ etapas da campanha nacional de multivacinação 1999- 2000 - Campo Grande/M.S

\begin{tabular}{|c|c|}
\hline Tipo de vacina & $\mathbf{N}^{\mathbf{}}$ \\
\hline Anti-amarilica & 141.214 \\
\hline Anti-haemoplilus influenza tipo B & 44.767 \\
\hline Anti-hepatite B & 53.403 \\
\hline Anti-pneumococo & 1.151 \\
\hline Anti-rábica humana & 4.218 \\
\hline Anti-rubéola & 1.598 \\
\hline Anti-sarampo & 18.895 \\
\hline BCG & 33.809 \\
\hline BCG (hanseniase) & 521 \\
\hline Contra meningite & 38 \\
\hline Dupla-adulto & 89.980 \\
\hline Dupla-infantil & 82 \\
\hline Sabin (anti-pólio) & 211.530 \\
\hline Toxóide tetânica & 0 \\
\hline Triplice bacteriana (difteria, tétano e & 59.343 \\
\hline coqueluche) & \\
\hline Contra meningite B & 3 \\
\hline Febre tifóide & 300 \\
\hline Dupla viral & 52.367 \\
\hline
\end{tabular}

Existe registro dos dados epidemiológicos das doenças de notificação compulsória ocorridas no município de Campo Grande. Apresento as principais notificações: 
Tabela 04 - Dados Epidemiológicos das doenças de notificação compulsória ocorridos no município de Campo Grande, por distrito Sanitário - 1999-2000

\begin{tabular}{|c|c|}
\hline Agravos & $\mathbf{N}^{\mathbf{0}}$ \\
\hline diarréia & 24.968 \\
\hline conjuntivite & 4.401 \\
\hline gardnerella & 3.628 \\
\hline dengue & 2403 \\
\hline candidíase & 2.074 \\
\hline Varicela & 1.093 \\
\hline Tricomoniase & 1.021 \\
\hline Rubéola (Suspeito) & 612 \\
\hline sífilis & 328 \\
\hline Hepatite não especificada & \\
\hline
\end{tabular}

Fonte: Perfil sócio-econômico de Campo Grande - 2001

Tabela 05 - Coeficiente de Mortalidade Proporcional por causas mais freqüentes em Campo Grande - 1999-2000

\begin{tabular}{|c|c|}
\hline Causa & $\%$ \\
\hline gastroenterite & 6,68 \\
\hline Lesão por arma de fogo & 6,29 \\
\hline pneumonia & 4,38 \\
\hline $\begin{array}{c}\text { Complicaçóes mal definidas d } \\
\text { doenças do coração }\end{array}$ & 3,35 \\
\hline Acidente de trânsito & 3,19 \\
\hline Acidente vascular cerebral & 3,07 \\
\hline $\begin{array}{c}\text { Acidente vascular cerebral } \\
\text { hemorrágico }\end{array}$ & 2,78 \\
\hline miocardiopatia & 2,62 \\
\hline Doença pulmonar obstrutiva & 2,24 \\
\hline crônica & \\
\hline Outras & 56,37 \\
\hline
\end{tabular}

Fonte: Perfil sócio-econômico de Campo Grande - 2001 
Conforme informações do Diretor Executivo da SESAU (2003), Campo Grande contribuiu para elevar os índices epidemiológicos do estado de Mato Grosso do Sul. No cenário nacional, tais índices superam as regiões Norte e Nordeste e estão equiparados aos índices da região Sudeste. A mortalidade infantil vem caindo de maneira acentuada. Alguns índices já estão aproximados dos índices das capitais Curitiba, Florianópolis e Porto Alegre.

Campo Grande, ainda, possui - periodo 1997-1999: 43 Centros de Educação Infantil; 10 creches domiciliares; 16 Centros Educativos de Múltiplas Atividades, para 7-14 anos; 4 Programas de Proteção Especial: S.O.S Abrigo, Casa Abrigo, Casa Lar, Centro de Atendimento Psico-Social (SOS Criança, Acolhimento, Apoio Sócio-Familiar); 13 entidades de Ação Social e Programas Especiais; 3 áreas de Apoio ao Trabalhador: intermediação de emprego, educação profissional e pesquisas; Fundo de apoio à Comunidade: Disque Solidariedade, Família Solidária, Projeto Mais; Instituto Mirim; Espaços Culturais Alternativos: 103 espaços abertos (praças e parques) e 14 espaços fechados (ginásios); 40 auditórios; 15 galerias de arte;18 entidades de infra-estrutura turística; 6 roteiros ecológicos; 37 roteiros culturais: história (7), Museus (8), Monumentos (8), igrejas (5), cinemas (3), teatros (6); 12 roteiros de compras; 17 tipos de roteiros de lazer e entretenimento; 6 roteiros arquitetônicos; 3 roteiros para realização de grandes eventos; 16 principais eventos Anuais; 12 salões de exposições temporárias; 2 projetos culturais; 19 bibliotecas.

Campo Grande arrecadou, em 2000, R\$ 316.882,16 (receita de capital total arrecadada); R\$ 294.565.968,46 (92,96\%), mais R\$ 22.316.193,48 (7,04: capital) Total $=316.882 .161,94$. Ainda, teve como despesas, R\$299.659.452,08; arrecadação de ICMS R\$366.910.165,39. Em 2000 despesas com pessoal, no município, alcançou $42,13 \%$ das receitas correntes. Desta arrecadação, $7 \%$ para a saúde pública. A partir de 2002 o Setor de Controle Social da SESAU passou a ter um orçamento anual. Em 2002, $\mathrm{R} \$ 40.000,00$ e em 2003, R\$60.000,00.

Em 2001, 2002, 2003 e 2004 seriam destinados, respectivamente, 9\%, 11\%, 13\% e $15 \%$. Comparando-se com o percentual previsto pelo estado do Mato Grosso do Sul, 
também respectivo a $2000,2001,2002,2003$ e 2004 , os valores $7 \%, 8 \%, 9 \%, 10 \%$ e $12 \%$, o municipio vem fazendo investimento maior já a partir de 2001.

São sete as regiões do municipio demarcadas pela PLANURB, as quais conformam quatro Distritos Sanitários, a saber: Distrito Norte - regiões do Segredo e Prosa; Distrito Sul - Centro e Anhanduizinho; Distrito Leste - região do Bandeira e Distrito Oeste Lagoa e Embirussu.

As Unidades estudadas dos CG estudados funcionam em regime de plantão, com baixa complexidade, nos periodos diurno e noturno ( $24 \mathrm{~h}$.), inclusive sábados, domingos e feriados. Além do pronto atendimento, oferecem, alguns, exames complementares de radio diagnóstico, ultrassonografia e pequenas cirurgias para os usuários da sua referida área de abrangência. Esta área de abrangência - o território - fica entendido aqui como um território geográfico e sócio-econômico. As regiões limítrofes de cada CRS terminam por configurar mais um território social do que geográfico para o CRS em questão, haja vista a proximidade da população deste e não daquele CRS de sua referência de seu território geográfico, determinado pela PLANURB.

$\mathrm{O}$ acesso às Unidades se faz por ruas e avenidas com asfalto, por transporte coletivo. $\mathrm{O}$ quadro funcional destes CRS é variado, contando com um maior número de profissionais de saúde que as demais Unidades do Distrito. Cada equipe de plantão é, normalmente, composta por 3-4 médicos, nas especialidades pediatria, ginecologia e clínico geral, uma enfermeira, um odontólogo, um farmacêutico (estes dois, presentes de Segunda a Sexta no periodo noturno), 7 auxiliares de enfermagem, dois auxiliares administrativos e dois auxiliares da equipe de apoio (acolhimento, digitação das receitas aviadas, orientação na pós-consulta médica).

Os profissionais médicos cumprem jornada de trabalho de seis e/ou doze horas (plantonistas fixos concursados). Os demais profissionais não são contratados especificamente como plantonistas, mas cumprem jornada de oito horas e, eventualmente, são escalados para trabalhar nos plantões. Os plantões são, ainda, revezados com médicos contratados, no intuito de cobrir todas as escalas. Via de regra, 
em casos de férias, licenças e outros não há substituição podendo, entretanto, ser a vaga suprida neste período, mediante necessidade comprovada.

Estão incluídas, no atendimento médico, consultas com ou sem observação, atendimentos de emergências e suturas. Desigualdades financeiras tem gerado instabilidades nas equipes, penúria em certas categorias (como foi o caso de 2002pediatria) e sentimento geral de insatisfação, principalmente porque os CRS são locais estressantes em virtude da sobrecarga de trabalho.

As AVEIANMs - procedimentos de vigilância epidemiológica, imunização e ações não médicas - são: consultas de enfermagem, visitas domiciliares, curativos, administração de medicamentos, inalações, retiradas de pontos, terapia de reidratação oral, coleta de exames laboratoriais, dentre outros, são prestados por enfermeiros e auxiliares de enfermagem pertencentes ao quadro funcional da Unidade. Tais serviços são prestados de maneira ininterrupta, a partir da demanda espontânea e, na maioria das vezes, como decorrência das consultas médicas do CRS e UBS. Em 2001, nos Centros Regionais de Saúde, os procedimentos de Enfermagem representaram, aproximadamente, $32 \%$ do total de AVEIANMs realizados nos Distritos Sanitários.

Os atendimentos odontológicos são oferecidos, na sua maioria, pelos Centros Regionais de Saúde. São oferecidos de domingo a segunda, no período noturno (19:00 - 7:00 hs.) e, sábados, domingos e feriados, em período diurno (7:00 - 19:00 hs., realizando ações como exodontias, restaurações provisórias e aberturas de canal. Nos plantões diurnos tem sido realizados procedimentos restauradores, enquanto que nos plantões noturnos, procedimentos curativos emergenciais.

As Unidades estão interligadas on line através de um sistema de grande porte - HYGEA -, tendo como referência os prontuários e gera vários relatórios: $\mathrm{CID}$, números de atendimentos, atendimentos por especialidades, inscritos em Programas, faltosos em vacinação, dentre outros. 
Inicialmente, nos CRS, os Conselhos eram independentes. Hoje todas as Unidades existentes no espaço do CRS conformam um único Conselho, sendo, por isso, duplicada sua composição para 8:4:4. 
5. A POLÍTICA DE CONTROLE SOCIAL NO ESTADO DE MATO GROSSO DO SUL/M.S - 1990 - 2002 
A Resolução No 33/92 aprovou o documento Recomendações para a Constituição e Estruturação de Conselhos Estaduais e Municipais de Saúde. Tais recomendações tinham o objetivo de acelerar e consolidar o controle social do SUS, por intermédio dos Conselhos Estaduais e Municipais de Saúde, com Base na Constituição Federal, na Lei Orgânica da Saúde (...). Esta Resolução define os Conselhos de Saúde da seguinte forma:

(...) órgão ou instância colegiada de caráter permanente e deliberativo, em cada esfera de governo, integrante da estrutura básica da Secretaria ou Departamento de Saúde nos Estados e Municipios, com composição, organização e competências fixadas em lei. O Conselho consubstancia a participação da sociedade organizada na administração do Sistema de Saúde, propiciando o controle social desse sistema.

Esta resolução relembra a participação comunitária, a paridade entre os segmentos, presidente eleito entre os membros do Conselho, em reunião plenária.

Dentre as competências dos Conselhos Estaduais de Saúde, podemos apontar sua atuação na formulação e controle da execução da politica de saúde incluídos seus aspectos financeiros e de gerência técnico-administrativa; estabelecer estratégias e mecanismos de coordenação e gestão do SUS (...); estimular a participação comunitária no controle da administração do Sistema de Saúde. Estas funções terminam emitindo reflexos nas ações de saúde dos municípios e, por sua vez, das Unidades de Saúde, conformando-se no fortalecimento da coordenação e gestão local na perspectiva da gestão participativa.

\subsection{CONTROLE SOCIAL E CONSELHO ESTADUAL DE SAÚdE DO MATO GROSSO DO SUL}

Pode-se dizer que, em Mato Grosso do Sul, houve um tímido esboço de movimento social através das articulações das forças populares, ainda, distantes de um amadurecimento adequado que assegurasse condições organizacionais suficientes para o 
encaminhamento de seus interesses (MTSUL 1989 u, referido por KADJAOGLANIAN 1997, p. 83).

A institucionalização do processo participativo em saúde no estado de Mato Grosso do Sul começa a acontecer em 1991, através da criação do Conselho Estadual de Saúde como órgão de deliberação coletiva.

O Conselho Estadual de Saúde do Mato Grosso do Sul foi criado pela Lei $N^{\circ} 1.152$ de 21/06/91. O poder Executivo encaminhou para o Legislativo no dia 17/05/91. Este devolveu a Lei aprovada em 11/06/91 e foi publicada em 21/06/91, com apenas um veto de caráter técnico. A legalidade estava colocada, mas o Decreto de nomeação dos conselheiros só foi publicado em 30/01/92, com a realização da primeira reunião somente em abril/92 - um intervalo entre a publicação e o início das atividades de 10 meses. Este fato revela o que Carvalho \& Santos (1995) comentam: "a implantação das leis não ocorrem por mérito da sua aprovação, mas imergem na sociedade por iniciativa da própria população que desencadeia o processo". Parece ser preciso um tempo de maturação, de digestão sócio-político-sanitária para que os segmentos da sociedade civil "acordem" frente a suas responsabilidades e direitos legalmente estabelecidos.

Mas no caso de Mato Grosso do Sul, este ato legal parece dizer que o Estado criava o Conselho até por uma questão de obrigatoriedade, haja vista a exigência de sua existência para celebração de convênio de descentralização com o governo Federal e a possibilidade de medidas punitivas, estabelecidas pela Resolução 89 de 01/02/92, para os estados que não cumprissem as determinações relativas ao funcionamento, em especial, o repasse de verbas.

O procedimento, adotado pelo executivo do estado do Mato Grosso do Sul, em tomar a dianteira na construção do Conselho Estadual de Saúde segue, mais ou menos, a média nacional e de acordo com CARVALHO (1995), "os Conselhos Estaduais de Saúde, por sua vez, em sua grande maioria, foram criados em meio a processos locais de razoável densidade politico-social. Em quase todos, a iniciativa partiu do interior do próprio 
estado". Este fato, acredito, comprometeu, inicialmente, a legitimidade de tais Conselhos.

De acordo com a Lei de criação do CES/M.S, Art. $2^{\circ}$, o Secretário Estadual de Saúde foi indicado como presidente e mais 24 membros representantes do governo, prestadores de serviços, profissionais de saúde e usuários. Como o presidente tinha voto de desempate, os outros segmentos já ficavam em desvantagem.

Esta situação seria reorientada em 20/10/94, por outra legislação. A composição do Conselho de Saúde, assim, seria: presidido pelo Secretário de Estado de Saúde e teria 24 (vinte e quatro) membros, dos quais $50 \%$ de representantes de usuários, $25 \%$ de representantes dos prestadores de serviços públicos e privados de saúde e $25 \%$ de representantes de profissionais de saúde.

O Decreto $\mathrm{N}^{\mathrm{a}} 6.345$ de 30/01/92 dispôs sobre a regulamentação do CES/M.S. Seu Regimento estabelece a finalidade, natureza, composição, competência, estrutura e funcionamento do referido órgão. O Art. $2^{\circ}$ - inciso $2^{\circ}$ diz que "os membros do Conselho Estadual de Saúde de Mato Grosso do Sul, (...) serão nomeados pelo governador do Estado, por indicação do Secretário de Estado de Saúde, ouvidos, quando houver, os órgãos de classe correspondentes, para mandato de 02 (dois) anos, permitida a recondução".

No primeiro mandato (91-93), apesar da recomendação de paridade, o segmento trabalhadores de saúde tinha menos que $10 \%$ (duas cadeiras), situação esta regularizada, mas sem registro destas mudanças. Naquela ocasião foram apresentados 12 nomes pelo Fórum dos Trabalhadores do SUS, mas foram indicados apenas 4 - dois efetivos e dois suplentes -, aumentando assim as vagas para os prestadores de serviços (públicos e privados). Estava criado um impasse político-jurídico-ideológico (REIS, 2001 p. 1516). Este fato parece indicar que tal postura do Executivo seja decorrente de uma articulação entre Executivo e Legislativo desde suas origens, uma forma de poder para o qual a sociedade ainda não está preparada para rechaçar. Aliás, a criação do Conselho nem mesmo foi iniciativa de segmentos da sociedade civil, então, exigir o quê? 
Nestes 8 anos de existência, o CES passou por diversas composições e diversos graus de intervenção da sociedade civil e do próprio governo. Entrevistas com conselheiros estaduais de saúde revelam "que grande parte das atribuições do CES/M.S não é exercida pelo mesmo, em especial, o controle do Fundo Estadual de Saude [e que] "faltam pessoas que se dediquem ao controle social financeiro da saude" (Reis, $2001 \mathrm{p}$. 2).

A Lei 1.149/91, que dispõe sobre a criação do Fundo Especial de Saúde de Mato Grosso do Sul, no art. $1^{\circ}$ : "O Fundo Especial de Saúde de Mato Grosso do Sul será gerido pela Secretaria de Estado de Saude, observados a politica, planos e programas aprovados pelo Conselho Estadual de Saúde (...)".

Documentos e entrevistas realizadas por REIS (2001, p. 9), indicam que "é possivel levantar as formas diferenciadas em que as forças politicas presentes em nosso estado relacionam-se com organizações da sociedade civil através dos Conselhos". Indicam também processos de avanço e retrocesso que ocorrem internamente na composição do Conselho Estadual.

Em relação aos segmentos da sociedade civil, vê-se que entidades como Lojas Maçônicas, Rotary Clubes e Lions Clubs, representam

ora um e ora outro segmento nos Conselhos Municipais dos Direitos da Criança, Conselhos Municipais de Saúde e, agora, por fim, nos Conselhos Municipais da Assistência Social, independentemente das suas atuações nos municipios e até na esfera estadual. O que tem determinado as suas inscriçð̃es, sem dívida, é a ampla vantagem de terem interlocutores tanto no poder legislativo quanto executivo (REIS, 2001 p. 18).

O comportamento de tais entidades comprometem a dinâmica social, reduzindo o jogo de forças e as contradições. Ao invés de existirem espaços a conquistar, existirão espaços a ocupar. 
Não consta em registro que as vagas ocupadas pelos prestadores de serviços - públicos e privados guardem proporção de número. Obedece "o jogo de forças presente no Poder Executivo, que convida este ou aquele representante de entidade prestadora de serviços com base em critérios politicos adotados pelo representante da pasta da Secretaria da Saúde” (REIS, 2001 p. 17).

A literatura disponivel em relação ao CES/M.S parece indicar que nesses primeiros passos da formalização do controle social, os atores mais em evidência estavam no segmento trabalhadores em saúde, mesmo porque muitos já vivenciavam experiências sanitárias nos movimentos populares em saúde e acumulavam uma história e nesta situação conseguiam promover alguma mobilização, principalmente aqueles funcionários federais da área da saúde e da previdência, fortalecidos pelos primeiros passos sindicais legalizados após a Constituição Federal de 1988 (idem).

Uma avaliação do funcionamento do CES realizada em 1993 tem a seguinte observação:

Participação ativa dos setores da sociedade para criação do CES, maioria de prestadores, isto é, não paritária; coincidência de mandatos dos representantes do CES com os do Governo; os conselheiros são indicados pelo Secretário Estadual de Saúde, sendo ouvidas as entidades, quando necessário; a perda do mandato é prevista no caso de faltas; prevista ainda criação de comissões especiais em áreas como recursos humanos, saúde do trabalhador; necessidade da pauta ser previamente distribuida aos membros; relação mais ou menos intensa com CNS e os CMS; articulação com universidades e instituições de pesquisas através de intercâmbio, consultas, reuniôes; divergências e conflitos entre componentes; predominância da força dos profissionais de saúde; poder executivo mais assiduo; controle executado quanto ao acompanhamento de recursos e revisão de contas do SUS. Mas há mudanças por maior conhecimento de legislação, situação sanitária e outros aspectos necessários ao exercicio do controle social em saúde - prática recente (CONSELHO ESTADUAL DE SAÚDE DO MATO GROSSO DO SUL - CES/M.S - ASP - grupo 9).

O Conselho Estadual de Saúde, através da Deliberação № 030/95, de 08/03/95, aprovou o documento "Recomendações para o Processo de Descentralização da Gestão das ações e serviços de saúde no Estado de Mato Grosso do Sul". Dentre as diretrizes desse 
documento, destaca-se "estimulo à criação e funcionamento dos conselhos de saúde" e "estímulo a estratégias de participação popular e controle social".

Em 09/01/97, o Secretário de Estado de Saúde deliberou (DELIBERAÇÃO/CES/N ${ }^{\circ}$ 046/97) sobre as orientações para organização e funcionamento dos Conselhos de Saúde no estado de Mato Grosso do Sul. Os conselhos não podiam ser criados por Decreto, mas por iniciativa do poder executivo municipal, podendo a Câmara dos Vereadores e a população, através do Ministério Público, pressionar o cumprimento da lei.

Interessante perceber que a própria lei colocou que a iniciativa pela formação dos Conselhos Gestores de Saúde dos municipios seria do próprio executivo municipal, cerceando a possibilidade de iniciativa popular, mas faculta à população pressionar e cobrar seus direitos. $\mathrm{Na}$ realidade, somente uma fatia pequena da população tem informações suficientes para deflagrar um processo desta natureza. Normalmente, quando as coisas não acontecem, a conduta de uma coletividade tem sido a espera, a passividade, a aceitação - como se as coisas fossem assim mesmo - ou a busca da solução pelo paternalismo ou clientelismo. Raramente, formaliza-se um processo junto ao Ministério Público ou mesmo junto ao PROCON. De acordo com Barros (s.d.), o Ministério Público e o PROCON são duas instituições importantes para assegurar o cumprimento das leis e o respeito aos direitos sociais.

No DOE $\mathrm{N}^{\circ} 4566$ (n.d), foi feita uma republicação do anexo único da Deliberação $\mathrm{N}^{\circ}$ 46/97, com 20 itens. No XX item, sub-itens - h, m, n -, pode-se ler:

h) Apreciar recursos a respeito de deliberações do Conselho Municipal, Conselhos Distritais e Conselhos Gestores de Unidade de Saúde;

m) Estabelecer critérios e diretrizes para implementação do Controle Social do SUS nas esferas municipais, distritais e locais, estimulando a participação comunitária no controle e administração do SUS;

n) Deliberar sobre a criação dos Conselhos Gestores de Unidades de Saúde em conformidade com as orientações já existentes.

Compete ao Ministério Público defender a ordem jurídica, o regime democrático e os 
interesses sociais e individuais indisponiveis (CONSTITUIÇÃO BRASILEIRA, Art. 127). O Promotor, ao responder por este Ministério, encaminhará ao Juiz o desrespeito da lei. Os desrespeitos podem ser: mau funcionamento dos serviços por falta de profissionais, a má conservação ou inexistência de materiais e equipamentos, a má administração ou o mau uso ou desvio dos recursos públicos destinados à saúde, dentre outros (BARROS, s.d.).

Em relação ao PROCON, há reduzida informação sobre seu papel. Seu código prevê proteção ao consumidor em relação aos serviços de saúde, como "mau atendimento nos postos de saúde ou hospitais, condições precárias de funcionamento dos serviços de sauide". Tais questões podem ser notificadas e providências necessárias deverão ser tomadas no sentido de se resolver o problema.

Pode-se recorrer ao Conselho Regional de Medicina, responsável pelo exercício profissional dos médicos ou a demais conselhos classistas da saúde. Citamos, ainda, os meios de comunicação, muito embora tenha tido a população dificil acesso, principalmente, quando a denúncia envolve autoridades públicas. Torna-se preciso descobrir os canais "para que a demincia pública se transforme em instrumento de pressão na defesa dos direitos de cidadania" (BARROS, s.d.). Em todos estes casos, há a necessidade de se registrar a denúncia, fato para o qual a população ainda não tem sido preparada. Soma-se a reduzida credibilidade na resolutividade das questões que envolvem o Estado. Compromete-se assim, o cumprimento da lei, favorecendo o desrespeito dos direitos sociais. Cristaliza-se a cidadania de escassez.

Tem-se, preliminarmente falando, alguns entraves, tais como: a nomeação de novos conselheiros demora em demasia, comprometendo a votação em plenária. Justifica-se que "a burocracia é tanta que essas coisas menos urgentes, como nomeação de conselheiros, ficam na espera do desafogo da papelada" (REIS, 2001 p. 20). Parece até que os conselheiros estão ali somente para "ver a carruagem passar". (...) No caso de Mato Grosso do Sul, a nomeação de quatro novos conselheiros do segmento de usuários levou mais de quatro meses para ser publicada em Diário Oficial". Tais encaminhamentos ficam por conta da vontade 'de politicos', ou seja, por conta de 
pessoas burocraticamente descompromissadas com "o andar da carruagem". Desestímulos também acontecem: endereçamento incorreto, dificuldades para passagem de ônibus para quem é do interior, acesso da cadeira de rodas para o deficiente físico, indicando ao coletivo a necessidade de assumir tais pequenos problemas para facilitar o acesso de grupos sociais alijados (REIS, 2001 p. 23).

Em 1996 fọi realizado um Programa de Capacitação de Conselheiros de Mato Grosso do Sul, numa parceria entre Fundação Nacional de Saúde/M.S, Universidade Federal de Mato Grosso do Sul, Secretaria de Estado de Saúde e Secretaria Municipal de Higiene e Saúde Pública de Campo Grande/M.S, operacionalizado pelo Grupo Técnico de Apoio aos Municípios, com vistas a otimizar o controle social, com os seguintes itens: capacitação de conselheiros, oficialização de canais de comunicação e articulação entre conselhos. O Programa tinha os seguintes objetivos específicos:

- discutir e informar sobre legislação do SUS, controle social e atribuições dos conselheiros de saúde;

- informar sobre as formas de gestão, financiamento e recursos humanos para o SUS;

- buscar formas coletivas de aprimorar a participação popular no controle social do SUS, a partir das realidades locais, respeitando a vivência de cada um, ou seja, a cultura própria de cada região;

- identificar e aprimorar a abertura de canais de informação em saúde, em especial, o perfil epidemiológico e o sistema local de saúde.

O Programa teria uma carga horária média de 100 horas, distribuídas em módulos temáticos de 20-24 horas e intermódulos de 45 dias, quando o aluno colocaria em prática o aprendizado no seu município. Estes alunos foram indicados pelas plenárias dos seus Conselhos Municipais de Saúde, daqueles enquadrados na gestão incipiente ou mesmo daqueles que ainda não tinham assumido nenhuma forma de gestão do SUS, em número de quatro por Conselho, com compromisso de repasse em seus municípios. $\mathrm{O}$ Programa foi dividido em 5 módulos:

MóDULO I: Conceito de saúde; conselho de saúde: legislação e composição; conferência de saúde. 
MÓDULO II: Princípios e diretrizes do SUS; organização do SUS e funções dos níveis de governo; atribuições dos conselhos de saúde.

MÓDULO III: Planejamento em saúde; financiamento do SUS; Recursos Humanos em saúde.

MÓDULO IV: Outras formas de controle social; avaliações e perspectivas dos conselhos de saúde.

ASSUNTOS COMPLEMENTARES: Saúde no Mercosul; legislação internacional da saúde; fóruns populares de saúde; demais a serem definidos nos grupos.

O Programa previa ação continuada entre 96-98, com participação de 31 conselhos/124 participantes; 30 conselhos/120 participantes e 25 conselhos/100 participantes, respectivamente.

A oficina realizada em 1996, foi de apenas 40 horas e indica, dentre os pontos positivos da avaliação, que os alunos conseguiram "(...) vivenciar o dia-a-dia de um Conselho, com seus jogos de interesse, sua luta pelo poder: mostrou os caminhos". A maioria dos comentários dos pontos negativos indica que o tempo foi pequeno para tantos conteúdos. Ainda, "a participação dos conselheiros de Campo Grande, acho que inibiu a nós do Interior que pouco sabiamos. (...) que houvesse um acompanhamento dos treinandos, pois o grupo deve se ver mais vezes, para expor os resultados obtidos nos municipios". Percebe-se o despreparo real dos conselheiros, a insegurança frente ao seu papel, a timidez para participar e se expressar, dentre outros.

\subsection{CONTROLE SOCIAL E CONSELHO MUNICIPAL DE SAÚDE DE CAMPO GRANDE/M.S}

A Lei Orgânica do município de Campo Grande no cap. IV - Da Saúde, Art. 140 entende que "A saúde é direito de todos e dever do Estado, garantido mediante políticas sociais e econômicas que visem à redução de risco de doença e de outros agravos e ao acesso universal e igualitário às ações e serviços para sua promoção, 
proteção e recuperação". Os artigos 141 e 142, ainda, colocam que ações e serviços de saúde são de relevância pública e que "o direito à saúde tem como fundamento condições dignas de trabalho, alimentação, educação, moradia, saneamento, transporte e lazer". O Art. 143 afirma que o sistema de saúde municipal se organiza de acordo com algumas diretrizes, dentre elas, a participação em nível de decisão do Conselho Municipal de Saúde "(..) para atuar na formulação de estratégias e no controle da execução da Política Municipal de Saúde".

O município de Campo Grande/M.S encontra-se hoje, de acordo com a NOB/96, habilitado na Gestão Plena do Sistema Municipal. A Lei № 2.784 de 27/12/90 criou o Conselho Municipal de Saúde, "de caráter consultivo que tem por finalidade auxiliar a administração na orientação, planejamento e interpretação de assuntos relacionados às atividades de saúde do Municipio" (Art. $1^{\circ}$ ). Compete ao Conselho Municipal de Saúde emitir pareceres sobre planos, programas, dentre outros. “(...) É um órgão colegiado, de natureza consultiva, (...) (Art. $3^{\circ}$ )". Na sua primeira formação com 12 membros, dos quais “(...) 8 serão indicados por entidades ligadas à saúde da Administração Pública Municipal, (...) (Art. $6^{\circ}$ - par. $\left.1^{\circ}\right)$ )" O parágrafo $3^{\circ}$ deste mesmo artigo diz que "os outros 4 membros que formam o plenário do CMS serão indicados por entidades representativas de profissionais de saúde, de entidades comunitárias, entidades filantrópicas ligadas à área de saúde e da Sociedade Civil Organizada". Percebe-se que estes dois artigos feriam principios da Lei 8.142/90, ao omitir a expressão deliberativo e afirmar a expressão consultivo. Ainda, o princípio da paridade na composição do Conselho foi, marcadamente, desconsiderado.

O Conselho Municipal deveria ser regulamentado em 60 dias, de acordo com a Lei $\mathrm{N}^{\circ}$ 2.784, mas o foi sete meses depois pelo Decreto $\mathrm{N}^{\circ} 6.340$ de 02/08/91.

Em 23/08/95, foi publicado no DOM/ Campo Grande/M.S o Regimento Interno do CMS, 4 anos e 8 meses depois de sua criação.

Em relação à composição do Conselho, o Art. $3^{\circ}$ - par. $1^{\circ}$ assim reza: "a representação dos diferentes segmentos deverá ser escolhida em fóruns próprios, convocados 
especificamente para esse fim". No par. $2^{\circ}$, "o coordenador de cada fórum de que trata este artigo indicará, por escrito, ao Presidente do $C M S / C G$, os nomes dos representantes eleitos para Conselheiros, (...)".

Percebe-se que, ao passar do tempo, as questões garantidas pela legislação federal, em relação aos conselhos de saúde, avançavam, principalmente no que se refere à composição, caráter e finalidade.

Os artigos $1^{\circ}$ e $6^{\circ}$ (Lei $\left.\mathrm{N}^{\circ} 2.784,27 / 12 / 90\right)$ passariam por algumas modificações, apresentadas no quadro abaixo, modificações estas resultantes da Lei $\mathrm{N}^{\circ} 2.811$, de 07/06/91 e pela Lei № 3.013, de 30/11/93.

QUADRO 01 - Redações diferenciadas dos artigos $1^{\circ}$ e $6^{\circ}$ - Lei $n^{\circ} 2.784 / 90$ - Campo Grande/M.S.

\begin{tabular}{|c|c|c|}
\hline $\begin{array}{c}\text { Art. } 1^{\circ}: \\
1^{a} \text { redação }: 27 / 12 / 90\end{array}$ & $2^{a}$ redação: 07/06/91 & $3^{a}$ redação: $21 / 08 / 00$ \\
\hline $\begin{array}{l}\text { Fica criado na Secretaria } \\
\text { Municipal da Higiene e da Saúde } \\
\text { Pública, o Conselho Municipal de } \\
\text { Saúde-CMS, de caráter consultivo, } \\
\text { que tem por finalidade auxiliar a } \\
\text { administração na orientação, } \\
\text { planejamento e interpretação de } \\
\text { assuntos relacionados às atividades } \\
\text { de saúde no municipio. }\end{array}$ & $\begin{array}{l}\text { Fica criado na Secretaria } \\
\text { Municipal da Higiene e da Saúde } \\
\text { Pública, o Conselho Municipal de } \\
\text { Saúde em caráter permanente e } \\
\text { deliberativo, órgão colegiado, } \\
\text { composto por representantes da } \\
\text { Prefeitura, prestadores de serviço, } \\
\text { profissionais de saúde e usuários para } \\
\text { atuar na formulação de estratégias e } \\
\text { no controle da execução da Política } \\
\text { Municipal de Saúde, inclusive nos } \\
\text { aspectos econômicos e financeiros, } \\
\text { cujas decisões serão homologadas } \\
\text { pelo chefe do Executivo Municipal. }\end{array}$ & $\begin{array}{l}\text { Fica criado no âmbito da Secretaria } \\
\text { Municipal de Saúde Pública, } \\
\text { Conselho Municipal de Saúde em } \\
\text { caráter permanente e deliberativo, } \\
\text { órgão colegiado, composto por } \\
\text { representantes da Prefeitura, } \\
\text { prestadores de serviço, profissionais } \\
\text { de saúde e usuários para atuar na } \\
\text { formulação de estratégias e no } \\
\text { controle da execução da Política } \\
\text { Municipal de Saúde, inclusive nos } \\
\text { aspectos econômicos e financeiros, } \\
\text { cujas decisões serão homologadas } \\
\text { pelo chefe do Executivo Municipal. }\end{array}$ \\
\hline $\begin{array}{c}\text { Art. } \mathbf{4}^{\mathbf{0}} \\
\left.\text { 1 }^{\text {a }} \text { redação: } 27 / 12 / 90\right)\end{array}$ & $\begin{array}{c}\text { Art. } \mathbf{4}^{\mathbf{0}} \\
\text { 2 }^{\mathbf{a}} \text { redação: } 21 / 08 / 00\end{array}$ & \\
\hline
\end{tabular}




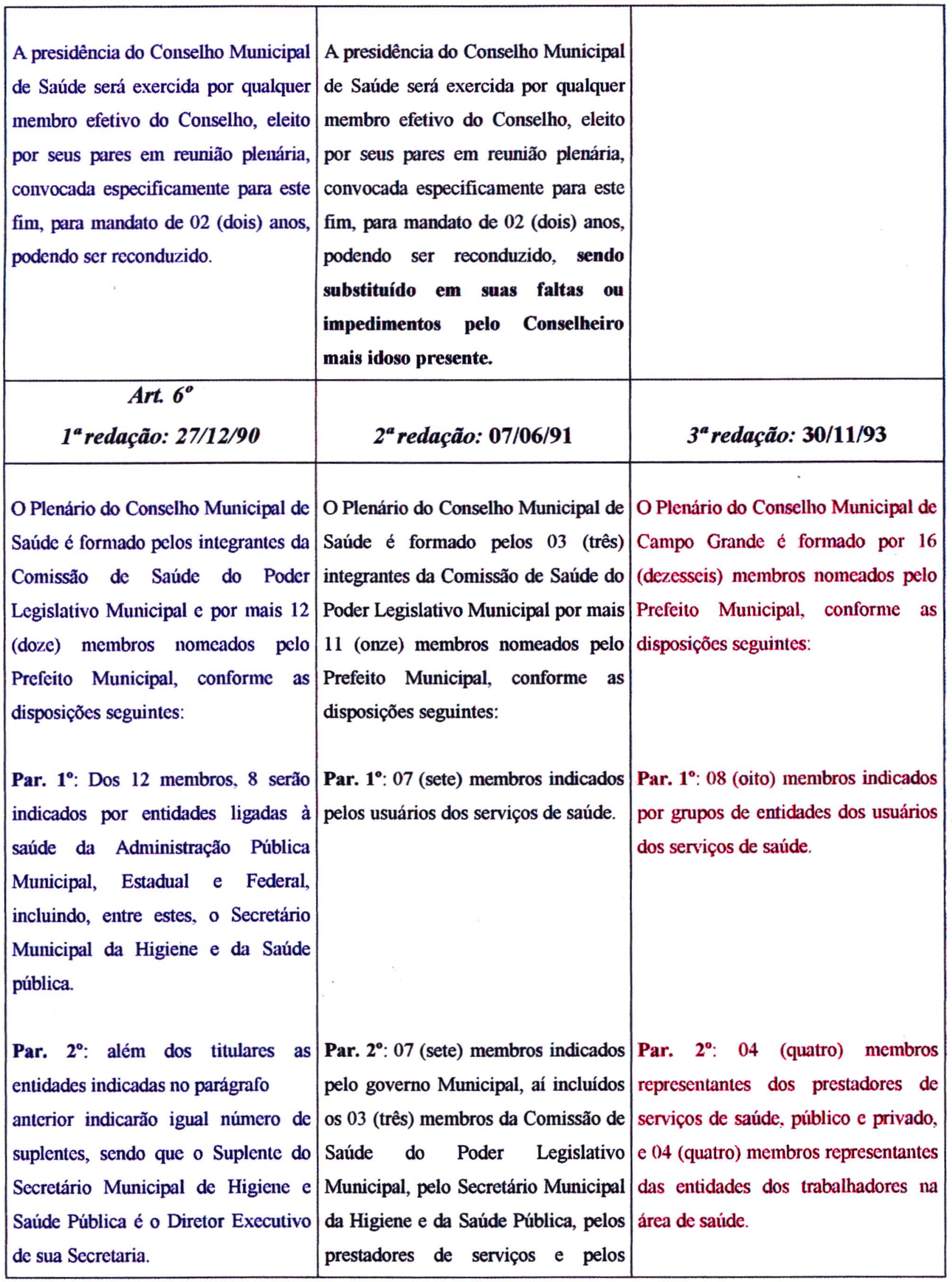




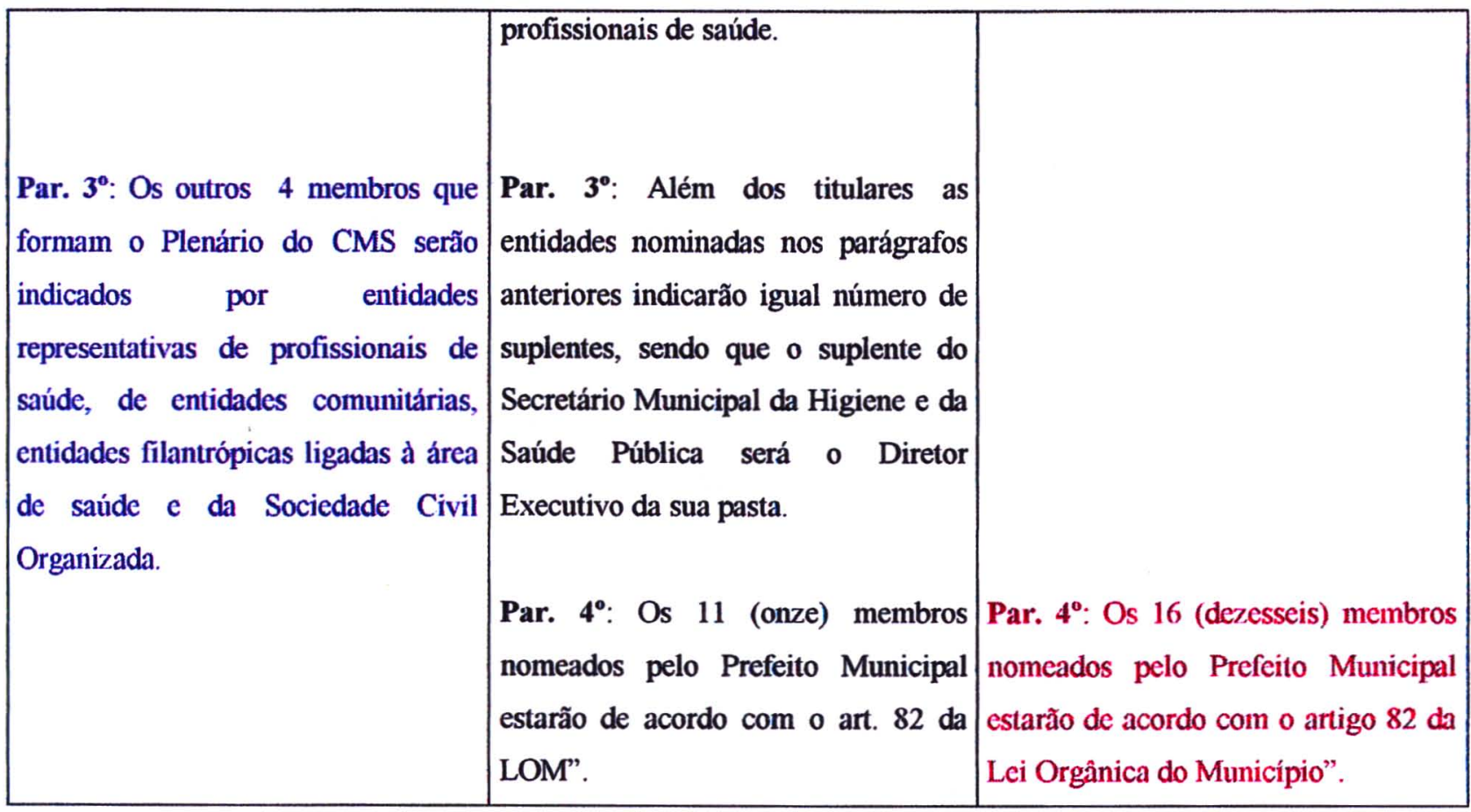

O Regimento Interno da SESAU, publicado no DOM - suplemento de 05/04/2001, não apresentava o Setor de Controle Social em sua estrutura. Essa omissão foi corrigida no DOM de 14/11/2001 e está ligado à Coordenação de Assistência e Programas de Saúde, a qual está ligada à Coordenadoria Geral de Assistência à Saúde.

\subsection{CONTROLE SOCIAL E CONSELHOS GESTORES DE UNIDADES DE SAÚdE DO MUNICÍPIO DE CAMPO GRANDE/M.S}

Na DELIBERAÇÃO № 05, de 23/08/95, editada no DOM de 25/08/95, o presidente do Conselho Municipal de Saúde aprovou o Regimento Interno dos Conselhos Gestores de Unidades de Saúde, no município de Campo Grande. Apresento alguns artigos pertinentes à temática de estudo desta pesquisa.Antes, porém, devo relatar que "este procedimento gerou protestos dos conselhos gestores da época, visto que o regimento interno deve ser adequado à realidade de cada centro de saúde" (MANUAL DO 
CONSELHEIRO, 1996).

É interessante fazer uma apresentação sucinta, ressaltando alguns aspectos do Regimento Interno dos Conselhos Gestores de Unidades de Saúde do Município de Campo Grande/M.S.

Art. $1^{0}$ - da finalidade: que "os Conselhos Gestores de Saúde (CGS) são órgãos colegiados, integrantes do Conselho Municipal de Saude de Campo Grande (CMS), vinculados às Unidades de Saúde, de caráter permanente e deliberativo, que tem por finalidade atuar na formulação de estratégias e no controle da execução da politica de saúde na área de cada Unidade de Saúde do Municipio de Campo Grande/M.S“.

Art. $2^{\circ}$ - das competências - incisos: "I - atuar na formulação e controle de estratégias para a politica de saúde desenvolvida pela Unidade de Saúde, inclusive nos seus aspectos econômicos, orçamentários, financeiros $e$ de gerência técnicoadministrativa; V - estimular a participação comunitária no controle, manutenção e desenvolvimento das ações de saúde; (...) VIII - tomar as medidas necessárias para permanente orientação dos usuários sobre os serviços oferecidos pela Unidade de Saúde; XVI - participar da elaboração e controle da execução do processo de avaliação das chefias";

Art. $3^{0}$ - da composição - "Os CGS são constituidos por 4, 8 ou 12 Conselheiros e respectivos suplentes" respeitando a paridade prevista em lei. Os representantes dos segmentos de usuários e de trabalhadores da Unidade de Saúde serão eleitos como conselheiros em fóruns próprios. Em relação aos prestadores de serviços, o diretor ou responsável pela Unidade é membro nato do CGS, devendo os outros representantes serem indicados pelo Diretor do Distrito Sanitário. Todos os conselheiros deverão ser nomeados por Resolução do Presidente do Conselho Municipal de Saúde e terão mandato de dois anos, podendo ser reconduzidos. Este periodo de mandato não se aplica aos representantes de Prestadores de Serviços de Saúde.

Art. $4^{\circ}$ ao $9^{\circ}$ - das normas - Neste artigo estão exaradas as normas sobre mandato, posse, direitos e deveres dos conselheiros, absenteísmo e substituição nas reuniões.

Art. $10^{\circ}$ ao $14^{\circ}$ - da estrutura - Orienta sobre a composição da diretoria e comissões de trabalho. 
Art. $15^{\circ}$ ao $31^{\circ}$ - do plenário - Trata das reuniões: tempo para convocação, calendário anual, falta de quorum, convocação e participação de pessoas não- conselheiras, realização e organização das reuniões, votação, leitura de relatórios, retificação de Atas, relato de processo, participação nas discussões dos processos e pedidos de vista de processos.

Art. $32^{\circ}$ - do presidente - Trás orientações sobre representação do CGS em atividades formais e informais, convocação de reuniões, encaminhamento de propostas, processo de empossar conselheiros, voto de qualidade, convocação dos foros próprios para escolha de entidades, implementação das deliberações e interessar-se pela promoção, proteção e recuperação da saúde.

Art. $33^{\circ}$ ao $37^{\circ}$ - das comissões de trabalho - Sobre seus papéis em relatar processos $e$, tomar diligências para esclarecimentos, emitir pareceres, funcionamento das comissões, apresentação de recomendações ao plenário.

Art. 38 ao $40^{\circ}$ - da secretaria executiva - Determina suas funções e competências.

Art. 41 ao $43^{\circ}$ - das disposições finais e transitórias - trata sobre prováveis modificações do Regimento Interno e de casos omissos.

No final de 2002, teve início um movimento para revisão do Regimento dos Conselhos de Unidade a ser concluído em 2003.

Tal como a constituição Federal, o Regimento Interno se assemelha a uma vitrine onde estão os objetos desejados, ou seja, os passos a serem seguidos e que, na maioria das vezes, pelas dificuldades, desinformação e barreiras, continua a ser uma vitrine. A otimização de um Regimento vai estar na dependência, principalmente, de informações adequadas, incluindo conhecimento da legislação pertinente, compromisso social dos conselheiros, capacidade de diálogo e negociação, representatividade, informações epidemiológicas e do estilo de se fazer política neste país. Tais ingredientes precisam ser buscados e cultivados.

Bem recente à aprovação do referido Regimento Interno (set./95), acontecia a $2^{\mathbf{a}}$ Conferência Municipal de Saúde. O Relatório Final recomendava, em relação ao Controle Social:

- a criação dos Conselhos Distritais no prazo máximo de 90 dias, “ com ampla 
mobilização pelos Conselhos Gestores de seus segmentos;

- Os Distritos Sanitários deveriam criar os Conselhos Gestores em cada Unidade de Saúde no prazo de 90 dias;

- Os Poderes Legislativo e Executivo Municipal deveriam regulamentar os Conselhos Gestores e Distritais;

- Os votos do Conselho Municipal que envolvessem interesses dos Conselhos locais deveriam respeitar os posicionamentos daqueles conselhos;

- Criação de plenária Municipal dos Conselhos, com a elaboração de boletim informativo, realização de encontros, seminários e mecanismos de divulgação;

- Criação de Ouvidoria - mecanismos de denúncia;

- Levantamento do grau de satisfação da comunidade em relação aos serviços de saúde;

- Realização de planejamento da Secretaria Municipal de Saúde de forma descentralizada e com a participação dos conselhos;

- Capacitação de recursos humanos do SUS para trabalhar com controle social e formação dos conselheiros com responsabilidade das organizações que participam dos Conselhos Gestores, dentre outros.

Quando se fala em capacitação de conselheiros, usualmente, os municípios utilizam uma cartilha e materiais diversos dirigidos aos CG, naqueles municipios que já tem seus CG em funcionamento. Uma consulta preliminar em alguns destes materiais (São Vicente/SP, São Paulo/SP, Campo Grande/M.S) mostra que as questões que parecem preocupar os organizadores destas cartilhas são questões voltadas para: o que é conselho gestor, sua composição, o processo de escolha dos conselheiros, funcionamento de um conselho, importância do Conselho, papel do conselho gestor. São preocupações básicas, iniciais e preliminares, é bem verdade. Não se percebe avanços para conhecimentos de caráter técnico-administrativo e político-social, embora com linguagem adequada e acessivel aos conselheiros, conduzindo-os para uma discussão e reflexão mais de caráter administrativo e organizacional.

Campo Grande/M.S tinha, naquela ocasião, total de 35 conselhos gestores, na zona 
urbana e rural. Destes, 15 participaram de oficinas de capacitação. Hoje - final de 2002 - já são 43 Conselhos.

O Manual do Conselheiro, elaborado em 1996, teve o apoio da FNS e da SES, sob a coordenação do Fórum dos Usuários de Saúde e Fórum dos Trabalhadores em Saúde de Campo Grande/M.S e traz os seguintes tópicos: O que é $\mathrm{CG}$; como é composto; como é feita a escolha dos três segmentos; o que é Fórum e Assembléia; como funciona o CG e qual o papel do conselho gestor.

Em novembro de 1996, acontecia o $1^{\circ}$ Encontro Municipal de Conselhos Gestores de Saúde, assim chamados os Conselhos de Unidades, promovido pelos Fóruns dos Usuários e Trabalhadores em Saúde, com o "objetivo de possibilitar a troca de experiência entre os Conselhos Gestores de Saúde, avaliar as ações desenvolvidas e debater propostas e encaminhamentos para o ano de 1997" (RELATÓRIO, 1996). Dos 15 Conselhos até então existentes, 9 dos quais em Centro de Saúde 24 h., compareceram 13, com um total de 72 participantes: 24 eram trabalhadores em saúde, 30 eram usuários e 12, prestadores de serviços. O tema escolhido para o encontro foi CONTROLE SOCLAL - SUS EM DEBATE. Os participantes trabalharam em 6 grupos, discutindo o Manual de Apoio aos Conselhos Gestores de Saúde e fazendo sugestões a ele.

Como primeiros avanços citavam-se: maior divulgação dos serviços prestados pelas Unidades de Saúde (US), melhoria do atendimento prestado; aproximação do centro de saúde com a comunidade; maior compreensão dos trabalhadores de saúde em relação aos objetivos dos Conselhos Gestores de Saúde, participação nas conferências distritais e municipais; permanência da ambulância nas US, instalação de autoclave, reformas nas US, melhoria da iluminação ao redor das US, limpeza das boca-de-lobos, melhoria da limpeza das US, instalação de bebedouro e telefone público nas US, ações conjuntas de segurança, permanência de chefes nas US, valorização da pessoa humana, integração de outros órgãos aos Conselhos Gestores, contatos com as lideranças comunitárias, etc. Percebe-se que as melhorias estão mais direcionadas para as questões dos serviços e da infra-estrutura dos serviços de saúde e dos bairros. 
Como dificuldades, foram relacionados os seguintes itens: falta de autonomia e recursos materiais e humanos dos distritos sanitários; centralização do poder com o secretário de saúde, dificuldades para reunir os conselheiros, desmobilização pelo não atendimento das deliberações das reuniões, falta de comprometimento por parte dos usuários frente aos conselhos, falta de espaço fisico para reuniões dos Conselhos Gestores, falta de segurança nas US, faltam recursos nas US, falta de conhecimento das finalidades dos conselhos Gestores por parte dos conselheiros, faltam materiais necessários para os trabalhos nos centros de saúde, falta assessoria e de um órgão de coordenação dos Conselhos Gestores na secretaria municipal, falta de credibilidade dos segmentos que compõem os conselhos, não existe delimitação geográfica das áreas de atendimento dos centros de saúde para as principais ações e falta de divulgação através dos meios de comunicação.

Muitas destas dificuldades e encaminhamentos se deve ao fato de, 9 destas US, serem de $24 \mathrm{~h}$., apresentando estrutura complexa, com ações de niveis primário e secundário, sem todavia priorizar uma ou outra ação e com usuários de demanda espontânea. Tais questões dificultam a participação de funcionários e usuários. Dos 6 Conselhos, somente 3 , naquela ocasião, estavam funcionando.

De posse do referido Relatório, os conselheiros abriram plenária para encaminhamentos e propostas, e que foram as seguintes:

- implantação das propostas aprovadas na $2^{\mathrm{a}}$ conferência Municipal de Saúde de 1996 (apresentadas anteriormente);

- que os diretores das US sejam escolhidos pelos membros dos Conselhos Gestores, desta forma, o cargo de direção passaria a ser descentralizado;

- realização de oficina de capacitação para CGS a cargo do CMS e Fóruns, com apoio da SESAU, SES e FNS;

- que a SESAU ofereça apoio, estrutura fisica e administrativa aos Conselhos Gestores e revisão do Regimento Interno dos CGS;

- descentralização das administrações dos Distritos Sanitários com a criação dos Conselhos Distritais de Saúde (isto significa que, apesar das propostas da $2^{a}$ 
Conferência Municipal em se criar os Conselhos Distritais em 1995, eles ainda não haviam sido criados);

- que as decisões, reivindicações dos CGS fossem feitas diretamente ao CMS e não somente através dos Diretores de Distrito Sanitário;

- capacitação dos trabalhadores em saúde para que estes não vejam o CGS como um órgão de punição;

- reestruturação do setor de Educação em Saúde da SESAU para coordenar a área do controle social da rede;

- implantar CGS em todos os centros de saúde da rede municipal;

- necessidade de oficialização da composição dos CGS bem como das decisões, em diário oficial;

- encontro municipal de CGS de seis em seis meses; lotação da chefia para centro de saúde satélite (unidades de serviços básicos) e que a sociedade civil busque realizar ações de saúde com apoio dos órgãos públicos;

- que o relatório final deste encontro seja encaminhado à SESAU e Prefeitura.

Em 1996, houve um refluxo dos CG em função da não-implementação das propostas aprovadas na $2^{\mathrm{a}}$ Conferência Municipal. Houve, na SESAU, instabilidade política com troca de Secretários, resultando na descontinuidade do controle social. Em 1997, através de parceria entre SESAU, SES/M.S e FNS foram criados mais 13 Conselhos de UBS.

O Regimento Interno da SESAU, publicado no DOM - suplemento de 05/04/2001 - não apresentava o Setor de Controle Social em sua estrutura. Essa omissão foi corrigida no DOM de 14/11/2001 e está ligado à Coordenação de Assistência e Programas de Saúde, a qual está ligada à Coordenadoria Geral de Assistência à Saúde.

A $3^{\text {a }}$ Conferência Municipal de Saúde aconteceu em Campo Grande no periodo de 1921/05/00. O Relatório Final da Conferência apresenta as falas dos conferencistas e as propostas inseridas nas seguintes áreas: modelo de atenção, modelo de gestão, controle social e recursos humanos. 
As propostas aprovadas pelos delegados da conferência para a área do Controle Social incluiam dois aspectos: 1. Estrutura e funcionamento dos conselhos e 2. Informação, Educação e Comunicação.

Discursos de alguns sujeitos que representavam conselheiros, sobre o Controle Social, afirmaram que:

a. de acordo com uma conselheira:

(...) nem sempre temos clareza de o que isto significa ou de como vamos exercer essa garantia constitucional. (...) a maioria da população desconhece seus direitos e não sabe também que, além de eleger os seus representantes de governo, pode intervir também nas decisões políticas dos governos sob os recursos públicos.E essa intervenção é justamente o exercicio do controle social, ou seja, sobre o destino dos nossos impostos e taxas, (...). A sociedade organizada além de fiscalizar, deve negociar e interagir com o governo para tomar decisões politicas de saúde e também formular as politicas e priorizar as ações de saúde, com objetivos claros, sabendo onde se quer chegar. $O$ controle social exercido pelos grupos mais organizados da sociedade, como é o caso dos usuários do SUS, tem um papel fundamental na mudança de paradigma, seja de modo de governo, seja da politica de saúde. Em função da ação participativa, estamos dando os primeiros passos, contribuindo para uma cara nova no Sistema Único de Saúde. Só o controle pela sociedade promove uma discussão democrática das verdadeiras aspirações populares (...).

b. de acordo com um conselheiro usuário:

Eu acredito que Campo Grande está tendo o que ela nunca teve em saúde, que nós já evoluimos muito, devo dizer, (...) mas também pela crescente participação popular. Será que a sociedade está plenamente preparada para dar seqüência a essas conquistas que acumulamos nesses últimos quatro anos? Acredito que não, pois ainda há dias em que o Fórum dos Usuários se reúne com não mais do que três ou quatro pessoas. (...) tivemos uma pesquisa recentemente (...), na qual não apareceu um só entrevistado que não conhecesse o nosso Fórum. (...) estive no gabinete do Dr.(...), nosso vereador, e vi que ele também desconhecia o Fórum - e ainda disse que nem reconhecia, se viesse a conhecê-lo... (...) se a Lei Federal garantiu o controle social do sistema de saúde no Brasil, nós usuários não podemos nos dispersar. (...) hoje nós temos bastantes coisas 
para contar, por exemplo, que a população de Campo Grande evoluiu muito em matéria de saúde, graças a essas duas pessoas que estão no poder [prefeito e secretária de saúde] $e$ estão permitindo a organização dos usuários. Mas fazer não é só gastar tijolo e cimento, não é só comprar novas máquinas e equipamentos. Uma boa saúde se faz também com recursos humanos, que são fundamentais. E é ai que pecamos muitas vezes, quando deixamos de cobrar a qualidade daqueles que prestam o serviço de saúde. (...) Será que exame é mesmo uma solução naquela hora em que a pessoa está com dor? Será que não seria o caso de uma consulta bem feita (...) um atendimento mais humano? Uma orientação até na forma de se alimentar? Nós usuários não queremos mais pedir esmola ou favor, seja de um médico, seja de quem for.Nada disso, nós temos direitos. Por que temos de ter consultas de 15 minutos, ou quota de dezesseis pacientes por periodo? Não precisamos ficar mendigando aquele profissional que talvez tenha se formado em faculdade pública, com o dinheiro do povo e que mesmo assim não quer devolver ao povo aquilo que dele ganhou. (...) para alcançarmos qualquer mudança nessa área, tem que haver uma mudança radical nos nossos valores, tanto morais como sociais. Nós temos um governo que dificulta, nós temos um governo federal que não quer valorizar o social, (...). Eu acho que compete à sociedade organizada inverter essa situação, já que temos a cada quatro anos essa possibilidade. Nós somos responsáveis por tal mudança e nós não devemos perder as oportunidades, usando a arma do voto.

Para AROUCA (1987, p. 15), as barreiras da participação e do controle social são forças conservadoras, partidos políticos, reduzido e/ou fragmentado acesso às informações, corporativismo, reduzido nivel de organização e conscientização da comunidade ${ }^{1}$, rede privada de serviços, dentre outros. Acrescentamos ainda e, de acordo com JACOBI (1992, p. 32), o clientelismo, dificuldade de encaminhamentos das propostas de participação, haja vista a falta de agilidade nas decisões, "o problemático compromisso do corpo de funcionários e, principalmente, a ausência de critérios de representação $e$ canais administrativos que garantam o suporte institucional à interação com os grupos mais organizados e com os movimentos populares". Causam ainda resistência: rede de micropoderes, padrão arcaico do uso da coisa pública, cultura, políticas públicas e dificuldades para conciliar interesses sociais e econômicos.

\footnotetext{
${ }^{1}$ De acordo com JACOBI (1992 p. 40), este foi o principal motivo na experiência de São Paulo (19891992).
} 
A imprensa também tem contribuído para engrossar o rol de dificuldades, ao mostrar para a opinião pública, as mazelas do serviço público, gerando a impressão de que os organismos públicos não têm capacidade de resolver problemas mais prementes.

O controle social também tem sido visto pela mídia dentro de uma concepção fiscalizadora, a exemplo do "O Jornal Proposta", de 1987-1990 (idem) . A Carta de Olinda afirma que o controle social “(..) não se reduz a aspectos de fiscalização ou execução dos serviços, sendo mais globalizante e integrador. Deve refletir um real poder da população em modificar politicas, planos e programas, não só no campo da saúde".

Alguns estudiosos consideram os órgãos colegiados da saúde como o caminho da tutela e da cooptação, pois os limites da participação estarão nos limites da "(...) regulação conseguida pela legislação, que Boshi denomina de mecanismo de "cidadania regulada" (referido por WESTPHAL 1992, p. 30). 
6. DINÂMICA E FUNÇÃO DELIBERATIVA DOS CONSELHOS GESTORES DE CENTROS REGIONAIS DE

SAÚDE: influências na formulação de políticas de saúde Campo Grande/MS - 1994/2002 
Deliberar - do latim - deliberare, significa, de acordo com o Dicionário AURÉLIO (2000), resolver após exame ou discussão, decidir, assentar; resolver... [ainda], meditar no que se há de fazer, consultar a si mesmo ou a outrem, ponderar, refletir, discutir, examinar (...) resolver-se consideradamente, decidir-se, determinar-se. $\mathrm{O}$ mesmo Aurélio exemplifica: Reuniu-se o Parlamento para deliberar sobre a situação nacional.

Deliberar tem a ver com autonomia, escolher alternativas, tornar-se responsável pelos seus atos.

Do verbo deliberar vem o adjetivo deliberativo que é referente à deliberação, ao voto. Deliberação, por sua vez, é a ação de deliberar, discussão para se estudar ou resolver um assunto, um problema ou tomar uma decisão, reflexão, meditação, resolução, decisão. Exemplifica, ainda, Aurélio - O Conselho está em deliberação.

$\mathrm{O}$ ato de deliberar implica em movimento, numa ação contínua, um movimento dinâmico, respeitante ao movimento e às forças, (...) em atividade; diligente em alto grau; muito empreendedor (Aurélio, 2000). Em se tratando de Conselho, movimento de pessoas relacionado às forças presentes no grupo, imaginando-as numa intensidade que varia do fraco ao forte, do lento ao intenso ou vice-versa.

Conselho é definido por Aurélio como "corpo coletivo superior (...), corporação à qual incumbe opinar ou aconselhar sobre certos negócios públicos: conselho de saúde (...). De acordo com a Lei 8.142/90, estes Conselhos estariam constituidos para implementar e fortalecer a administração da saúde pública, nos seus vários niveis, na perspectiva da participação social, numa paridade em que, teoricamente, $o$ poder de decisão pudesse estar eqüitativamente distribuído, assumindo a função de gestor.

Gestores são as entidades encarregadas de fazer com que o SUS seja implantado e funcione adequadamente dentro das diretrizes doutrinárias (...) nas três esferas de governo, isto é, no nivel municipal, estadual e federal (...). Em cada esfera de governo, o gestor deverá se articular com os demais setores da sociedade (...). Deverão participar, também, representantes da população, que garantirão, através 
de entidades representativas, envolvimento responsável no processo de formulação das politicas de saúde e no controle da sua execução (ABC do SUS 1, 1990 p. 13, 14).

Fica claro, então, a definição do papel do Conselho de Saúde: participar da gestão, da gerência, da administração dos serviços de saúde pública, e de acordo com a Lei 8.142/90, com função deliberativo, atuar nas políticas de saúde nas instâncias correspondentes.

Ou seja, um órgão formado por representantes da população, trabalhadores e prestadores de serviços do setor saúde com a função, nos três níveis de governo, de meditar, ponderar; refletir; discutir; examinar, resolver; decidir [grifo meu] sobre as questões - estratégias, ações, políticas de saúde -, numa ação gerencial participativa, na decisão, acompanhamento, execução, avaliação das ações, serviços e Programas, dentre outros.

Os Conselhos estudados pertencem, de acordo com a tipologia de Unidades de Saúde do SUS, CENTRO DE SAÚDE - tipo 3, com as seguintes características:

\footnotetext{
atender grupamentos populacionais entre 15.000 e 30.000 habitantes; deverão contar com recursos de diagnóstico e tratamento de maior complexidade tecnológica; serão a referência para outros centros de saúde de menor complexidade, na sua área; poderão contar com atendimento de urgència, nas 24 hs. e, leitos de observação (ABC do SUS 3, 1990 p. 8).
}

Em Campo Grande/MS, tais Unidades de Saúde são denominadas CENTRO REGIONAL DE SAÚDE - CRS - ou Unidades de Saúde $24 \mathrm{~h}$.

Tendo estes conceitos bem definidos e transpondo para o cenário das Políticas de Saúde Pública no Brasil, atualmente, o Sistema Único de Saúde - SUS e, considerando o explicitado na Lei 8142/90 sobre o papel do Conselho Gestor - CG, fica claro o papel legitimo de um Conselho Gestor de Saúde e, neste caso, dos Conselhos Gestores de Saúde dos CRS. 
O processo de constituição dos Conselhos Gestores, nos CRS teve início no ano de 1994. Em 1995, ano marco na história dos Conselhos, já eram 12, nove de CRS e três de UBS. "A realização das Conferências Distritais de Saúde, em número de cinco, que culminou na II Conferência Municipal de Saúde, partiu de reivindicações e demandas colocadas pelos Conselhos Gestores, que participaram ativamente do processo (Manual do Conselheiro, 1996)", tendo a presença de 1300 pessoas.

Neste momento fértil de articulação das diferentes entidades populares permitiu à criação do Fórum dos Usuários de Serviços de Saúde. No ano de 1995, ainda, tinhase participação desses Conselhos em reuniões ordinárias do CMS, acompanhando e reivindicando melhorias nos serviços prestados. Propostas foram encaminhadas ao CMS e, por não implementação das propostas aprovadas houve um retrocesso nos Conselhos Gestores. Somava-se a este fato, instabilidade política na SESAU, com sucessivas trocas de Secretários, resultando na “(...) descontinuidade da politica de controle social até então existente. Em 1997, foi firmada uma parceria SESAU/SES/FNS com vistas ao fortalecimento do controle social. Foram criados mais 13 CG" de UBS e proposta para cinco oficinas de capacitação de conselheiros numa perspectiva problematizadora e participativa (idem).

A leitura das Atas foi deixando aflorar o tipo de dinâmica do funcionamento dos Conselhos através do que acontecia nas reuniões: apresentação dos presentes, informações e as demandas a serem discutidas e, no desdobramento destas, as queixas, as reivindicações-sugestões, decisões/deliberações e encaminhamentos, os quais eram formalizados via Oficios e/ou reuniões para demais instâncias de decisão no Distrito Sanitário, na Secretaria de Saúde do Município ou em outras instituições. $\mathrm{Na}$ trajetória dos registros ficam evidentes, também, alguns avanços e conquistas dos conselheiros para a comunidade, para a Unidade e para os $C G$.

Minha vivência, como docente da Universidade Federal de Mato Grosso do Sul, nos anos de 1995-97, permitiu ouvir de colegas professores que participavam de CG de Unidades de Saúde do município que o maior problema, naquele momento, era o encaminhamento das decisões/deliberações. Elas se perdiam no caminho por falta de 
alguém para acompanhar o processo até seu desfecho ou por morosidade da entidade/pessoa solicitada. E isto comprometia seriamente a função deliberativa do CG.

Hoje, pelo que se percebe nos registros, por minhas observações das reuniões, algumas questões do questionário e entrevistas, esta responsabilidade está a cargo do(a) Diretor(a) do CRS, com a supervisão do(a) coordenador(a) do Conselho, o(a) qual, no dia seguinte, já providencia os devidos encaminhamentos com uma melhor supervisão dos conselheiros. E isto porque, em todos os Conselhos estudados, existem conselheiros que participaram de todas as gestões daquele Conselho ou vieram de um Conselho para outro e já estão mais experientes quanto ao acompanhamento dos encaminhamentos.

Passo, então, a apresentar os Conselhos Gestores estudados analisando sua composição, periodicidade das reuniões, atores sociais atuantes, suas dinâmicas propriamente ditas $\mathrm{e}$ a influência na função deliberativa na decisão/formulação/condução das políticas sanitárias em Campo Grande e/ou no âmbito do estado do Mato Grosso do Sul. 
6.1 CONSELHO GESTOR DE SAÚDE DO CENTRO REGIONAL DE SAÚDE "Dr. GÜINTER HANS" BAIRRO NOVA BAHIA DISTRITO NORTE - CAMPO GRANDE/M.S - 1994/2002 
O CRS do bairro Nova Bahia ${ }^{1}$ iniciou suas atividades em 12/01/1994, por uma demanda de famílias e grupos da população dos bairros daquela área de referência.

$\mathrm{Na}$ primeira reunião de seu CG, encontravam-se as seguintes pessoas: presidente da associação de moradores dos bairros da sua área de abrangência, representantes da Secretaria Municipal de Higiene e da Saúde Pública, diretor administrativo do Centro de Saúde e usuários dos serviços de saúde, com o objetivo de eleger o Grupo de Melhoria de Qualidade - nome dado, naquele momento ao CG. Uma enfermeira e um enfermeiro, representantes da SESAU, disseram do

interesse do Prefeito Municipal em melhorar a qualidade de atendimento nos Postos de Saúde, dai a criação do Grupo da Qualidade. (...) será um trabalho de conscientização para a comunidade, pois terá a oportunidade de participar mais, (...) atrovés de eleição, e os eleitos serão representantes da região de atendimento do Cento de Saúde. (...) O grupo será um elo entre a Secretaria e a Comunidade, principalmente sobre os cuidados da estrutura do prédio (...) [grifo meu], e o Grupo faz parte do Sistema Único de Saúde. Enfoca a importância da participação de todos, independente da politica partidária, pois esses atendimentos é aberto aos Centros de Saúde do municipio (ATA № 01/94, fl. 1).

Um presidente de bairro relatava que o projeto da construção do Centro de Saúde, na gestão passada (antes de 94) foi dificil, pois tiveram problemas para a liberação do terreno, mas que o grande numero de familias residentes nesta região foi o grande motivo para a aprovação do projeto. A proposta era de reunião semanal

para discutir os problemas do Centro de Saúde, propor soluções e apresentá-las ao Diretor do Centro de Saúde, e quando as soluções não puderem ser viabilizadas no próprio Centro de Saúde, um representante do grupo, juntamente com o Diretor, irđ̃o até a Secretaria para reivindicarem as soluções (idem).

Uma enfermeira da SESAU colocou

\footnotetext{
${ }^{1}$ Os nomes dos CRS são conhecidos pela população pelos nomes dos bairros e não pelos nomes oficiais.
} 
que o Grupo de Melhoria da Qualidade terá que respeitar a figura do diretor do Centro de Saúde e que todas as decisões devem ser repassadas primeiro ao mesmo, para depois serem enviadas a outras pessoas, caso as soluções não sejam possíveis no Centro de Saúde (idem).

O Grupo deveria elaborar um Regimento Interno para estruturação do mesmo. Naquela ocasião, houve uma queixa: não havia vigias no Centro de Saúde e que [este item] deveria ser o primeiro assunto de discussão do grupo, pois já se havia tentado abrir a porta da frente do ambulatório. Um líder de bairro colocou a dificuldade dos presidentes de bairros em se comunicarem para o repasse das informações devido os bairros serem distantes uns dos outros e que os eleitos iriam olhar somente para os problemas do seu bairro. Outro líder disse que a existência desse Grupo seria muito bom, pois, às vezes, era indagado sobre os atendimentos do Centro de Saúde e não sabiam responder e com esse trabalho, ficaria mais fácil informar a comunidade (ATA). A expressão importância do $C G$ é presente na maioria das Atas. Referemse à importância do CG para a Unidade e para a comunidade.

\subsection{A. ASPECTOS DO FUNCIONAMENTO DO CONSELHO GESTOR DO CRS "Dr. GUINTER HANS" - B. NOVA BAHIA - DISTRITO NORTE - CAMPO GRANDE/M.S 1994/2002}

\subsection{A.1 PERIODICWADE DAS REUNIÕES}

Em 1994, aconteceram 18 reuniões com periodicidade, variando de 4 a 28 dias, com reuniões ordinárias e extraordinárias. Nesse periodo, houve uma paralisação de 3 meses e 8 dias entre os meses de junho a outubro/94. $\mathrm{O}$ ano encerrava e abria um espaço de 2 meses e meio para a próxima reunião, em 15/02/95. Esse ano também presenciou instabilidade na periodicidade das 7 reuniões, com intervalos de 6 dias a 3 meses e meio. No ano de 1996, foram realizadas 14 reuniões, sendo 2 com falta de quorum e periodicidade mais estável, variando de 8 a 35 dias. Em 1997, houve 11 
reuniões com periodicidade de 14-35 dias, numa média de intervalo de 28 dias entre as reuniões.

Em 1998, aconteceram 10 reuniões, com periodicidade variando de 14 - 35 dias e pausa de 110 dias; em 1999, 2 reuniões e pausa de 19 meses; em 2000, 3 reuniões com 14 meses de pausa; em 2001, 2 reuniões e o ano encerrava. Em 2002, o CG se fortalece, realizando nova eleição e 15 reuniões, com periodicidade variando de 6 48 dias.

O público fica sabendo da pauta e das reuniões do CG através do Mural, convidados, agentes de saúde do PACS, funcionários.

TABELA 06 - Periodicidade das reuniões do Conselho Gestor de saúde do CRS “Dr. Güinter Hans" - B. Nova Bahia 1994/2002.

\begin{tabular}{|c|c|c|c|c|c|}
\hline ANO & $\begin{array}{l}\mathbf{N}^{\circ} \\
\text { REUNI } \\
\text { ÕES }\end{array}$ & PERIODICIDADE & PARALIZAÇÃO & PARIDADE & $\begin{array}{l}\text { COORDE } \\
\text { NAÇÃO }\end{array}$ \\
\hline 1994 & 18 & $4-28$ dias & 98 dias & $\begin{array}{l}12 / 01-3: 2: 2 \\
17 / 11-4: 2: 2\end{array}$ & usuário \\
\hline 1995 & 6 & $\begin{array}{l}6 \text { dias }-3 \text { meses e } 15 \\
\text { dias }\end{array}$ & $\begin{array}{l}90 \text { dias } \\
(2 \text { vezes })\end{array}$ & $12 / 5$ & \\
\hline 1996 & 13 & $8-35$ dias & 2 sem quorum & $18 / 09-4: 2: 2$ & usuário \\
\hline 1997 & 11 & 14-35 dias & & & \\
\hline 1998 & 10 & $14-35$ & 110 dias & $21 / 01-4: 2: 2$ & Usuário \\
\hline 1999 & 2 & & $\begin{array}{l}24 / 02-18 / 07 / 00: \\
19 \text { meses }\end{array}$ & & \\
\hline 2000 & 3 & $16-28$ & $\begin{array}{l}1 / 9-29 / 11 / 01: 14 \\
\text { meses }\end{array}$ & $18 / 07-2: 2: 1$ & Usuário \\
\hline 2001 & 2 & 15 dias & & $15 / 12-4: 2: 2$ & Usuário \\
\hline 2002 & 15 & $6-48$ dias & & $8: 4: 4$ & Usuário \\
\hline
\end{tabular}

FONTE: Atas das reuniões 


\subsection{A.2 COMPOSIÇÃO DO CONSELHO GESTOR}

$\mathrm{Na}$ primeira reunião, o objetivo era já eleger os conselheiros. Embora tenha sido convidada a maioria dos líderes de bairros, havia poucos representantes, pois o CRS não conseguiu uma listagem com os nomes de todos. $\mathrm{O}$ grupo, então, deliberou que, uma semana depois (19/01/94), seria a eleição dos representantes da comunidade e que a assistente social do CRS mandaria convites com antecedência para associação de moradores dos bairros daquela área de abrangência para se ter maior número de líderes na $2^{\mathrm{a}}$ reunião. Os eleitos seriam escolhidos entre os presentes e foi apoiado pela maioria dos presentes desta primeira reunião.

O Diretor do CRS anunciou que já haviam escolhido os representantes dos trabalhadores em saude. Foram apresentados 2 titulares - assistente social e auxiliar de enfermagem e 2 suplentes - auxiliar de enfermagem e zeladora.

Conforme o combinado, dia 19/01/94, houve a eleição, em aberto, entre os 29 presentes, dando chance para se manifestar quem estivesse interessado. O Diretor do CRS explicou o objetivo da diretoria do CG e tirou as dúvidas dos presentes. $O$ objetivo e as dúvidas não estão registradas (Ata $N^{\circ} 2$ ). Estiveram onze presidentes das associações de moradores: Conj. Novo Minas Gerais, Jd. Presidente, Conj. Novo Paraná, Conj. Novo Sergipe, Conj. Novo Maranhão, Campo Novo, Jardim Cerejeira, Jardim Anache, Novo Alagoas, Jd. Columbia, Mata do Jacinto e Clube de Mães dos bairros Jd. Campo Verde, Colina N. Sra. Aparecida, N. Sra. Aparecida I, Mata do Jacinto e Taquaral Bosque. Ainda, representante da SESAU e Diretoria do CRS Nova Bahia.

Os usuários eleitos pertenciam aos bairros: Conj. Novo Minas Gerais, Jardim Presidente e Taquaral - três titulares e três suplentes. A posse do CG foi para um período de dois anos. Nas primeiras Atas, não fica explícito quem representaria o segmento Prestador de Serviços, mas pelos registros, percebe-se sempre a presença do Diretor do CRS e alguém representando a SESAU (ATA No 2). 
O Regimento Interno dos CG das Unidades de Saúde ainda não estava elaborado. A primeira composição do CG eleito ficou com 3 Usuários (3 titulares e 3 suplentes), 2 trabalhadores de saúde ( 2 titulares e 2 suplentes) e 2 prestadores de serviço - 3:2:2. Vê-se a inexistência de paridade proposta legalmente pela Lei $N^{\circ} 8.142 / 90$.

Nos primeiros anos constata-se um maior número de reuniões extraordinárias, e os fatos podem indicar pressa na busca da solução dos problemas, e algumas mudanças na composição do $\mathrm{CG}$, pelo abandono de titulares, por vários motivos: desinteresse, pouco tempo, envolvimento com outras atividades, dentre outros.

O número de presentes nas reuniões variava de 5 a 33, sendo que a média era em torno de 5 - 9 pessoas. Os fatores que influenciavam eram: eleição e debate de assunto conflitante. Quando as reuniões se distanciavam muito ou havia desistência de conselheiros, a tendência era esvaziar o quorum. Mas sempre havia interesse de algum ou de alguns conselheiros para a retomada das atividades do Conselho e, então, através de novos convites, o número de pessoas voltava a aumentar nas reuniões.

\subsection{A.3 REPRESENTATIVIDADE - ATORES}

A representação, neste início, era realizada pelos lideres das associações de moradores. O coordenador nesse CG sempre foi um usuário e líder comunitário.

Demais atores sociais atuantes neste processo incluíam, raramente, pessoas das comunidades da área de abrangência do CRS e, o nível de representatividade, normalmente, estava na dependência direta da atuação dos lideres comunitários no CG. Nas reuniões, os conselheiros usuários, algumas vezes, se faziam acompanhar de outros usuários desse CRS. Escolas, clubes de mães, associação de pais e mestres das escolas, pastores, somavam-se aos atores esporádicos, desse CG.

Da formação da última eleição - oito conselheiros -, 7 conselheiros devolveram os questionários, quatro masculinos e 3 femininos. A idade média é de 49 anos Quanto à escolaridade, dois tem pós-graduação, três, $2^{\circ} \mathrm{G}$ completo, um, $2^{\circ} \mathrm{G}$ incompleto e 
um com ensino superior completo. A renda familiar está assim distribuída: quatro com três a quatro salários mínimos, um, cinco a sete salários, um, de um a dois salários e um não respondeu. Quanto à profissão, um é aposentado, um, cabeleireiro, dois, da SESAU, uma, do lar, um, desempregado e um, funcionário público municipal. O motivo que os levou a serem conselheiros foi auxiliar a melhorar a saúde e acreditar em transformações, o cargo que ocupa, obter melhores resultados. De acordo com estes conselheiros as decisões são tomadas de maneira paritária, mas os trabalhadores influenciam bastante pelo domínio prático-teórico. O papel do CG tem sido de solucionar, resolver, amenizar as dificuldades da população em relação aos usuários (ATA).

No segmento prestadores de serviços, o diretor administrativo do CRS tem manifestado desejo e interesse na participação da comunidade nas reuniões. Seguidamente reiterava a importância, os objetivos e a necessidade da participação sistemática dos conselheiros usuários, não só na divulgação do $\mathrm{CG}$, via reuniões na comunidade, bem como na identificação dos mais variados tipos de problemas e na execução de alguns serviços - acompanhamento e conversa com as pessoas nas filas de agendamento e na supervisão informal dos setores do CRS, dentre outros.

Representantes da SESAU - setores de Saúde Coletiva, Controle Social, Vigilância Sanitária, Secretário(a) de Saúde e o Prefeito - têm estado presentes quando a questão mostra um grau maior de dificuldade para sua solução, ou quando se instala uma situação de conflito mais expressivo.

Quanto aos trabalhadores de saúde, formado por médicos e enfermagem superior e auxiliar, têm estado sempre prontos a responder as questões levantadas; indicar, sob sua ótica, as implicações presentes em cada problemática, e dispostos em preparar e viabilizar os encaminhamentos, frutos das deliberações do CG, apesar de, sempre, haver alguns entraves presentes. Têm, ainda, se mostrados relativamente abertos para críticas e mudanças, salvo em alguns casos, com maior resistência do corpo clinico, muito embora, boa parte dos médicos vem se mostrando sensibilizados com as problemáticas dos usuários. Esta postura aparece de maneira subjetiva nos 
questionamentos de alguns destes médicos que, esporadicamente, se fazem presentes às reuniões.

Surgem, também, como atores sociais clube de mães, agentes de saúde da FUNASA, Diretor do Distrito, Pastoral da Criança, representantes de algumas instituições dos bairros da área de abrangência do CRS. Em situações pontuais, nota-se a presença de acadêmicos e docente da disciplina Administração em Saúde Pública, do curso de enfermagem da UFMS. Ainda, professores de Ensino Fundamental de Escola Pública e Assistente Social do Hospital Dia (HD) ${ }^{2}$. O único movimento organizado em saúde é a pastoral da saúde e da criança.

De acordo com os conselheiros o papel do CG tem sido participativo, importante na parceria de gerenciamento, disponibilidade. Controle social é entendido como participação da sociedade nas decisões públicas, participação ativa da comunidade em decisões de politicas públicas; gestão participativa, como o gestor decide coletivamente, a sociedade através dos representantes atuar junto do poder executivo. $O$ conselho poderia ter mais qualidade de sugestões e ações (ATA).

Gestão participativa é entendida, de acordo com os registros das Atas, como onde o gestor aceita decisões coletivas e controle social como participação da sociedade na área pública (ATA).

\subsection{B DINÂMICA DO FUNCIONAMENTO DO CONSELHO GESTOR: prática de atuação do Conselho}

Depois de uma semana de formalizado e empossados os conselheiros, o Diretor Administrativo da SESAU (28/01/94) colocou a dinâmica básica para o funcionamento do CG: deveria enviar relatório quinzenal ao Diretor do Centro de Saúde e, em caso de problemas insolúveis, deveriam procurar a SESAU, a qual teria

\footnotetext{
${ }^{2} \mathrm{O} H D$ funciona no mesmo terreno mas, com gerenciamento independente, atuando em doenças infecciosas e parasitárias.
} 
prazo para solucionar os problemas (ATA). Em caso negativo, dever-se-ia procurar o Prefeito. O primeiro relatório foi enviado em 24/02/94.

Os conselheiros observavam que existiam, em alguns momentos do atendimento, poucos funcionários para a demanda presente no CRS, o descaso de alguns funcionários (médicos e enfermeiros) (ATA), manifestados em alguns atendimentos e em alguns relacionamentos, algumas vezes, muito críticos.

Existe um calendário de reuniões o qual, normalmente, é seguido. Digo normalmente porque, quando não há quorum em alguma destas reuniões, faz-se reunião extraordinária - convocada pelo coordenador do CG e avisado os conselheiros num processo de "corpo-a-corpo", ou se espera a próxima reunião ordinária. A agenda, hoje, é construída com a participação dos segmentos, mas dificilmente é anunciada na forma de pré-agenda. Os conselheiros trazem as sugestões $e$ as entidades têm poder de influência sobre os conselheiros que as representam (ATA).

O caminho para a busca de consenso dava-se sempre num processo de ir-e-vir: levantamento das temáticas, queixas e discussões, sugestões, encaminhamentos; levantamento das temáticas, discussão, sugestões, rediscussão, sugestões e encaminhamentos, ou o tema saía temporariamente do cenário para posterior discussão, a depender do quorum para as reuniões.

O CG foi registrado em março/98 no Cartório do $4^{\circ}$ oficio com a posse dos conselheiros e paridade de 8:4:4. Os conselheiros são tidos como elo entre comunidade e CRS (jan./98) e o verdadeiro papel do CG era sempre lembrado, com discussões sobre suas atribuições.

O CG é a função de informações da comunidade e setor de saúde pública, é a maneira de ajudar a administrar, com criticas construtivas, trabalhar junto com a administração [grifo meu] entrosamento das lideranças. (...) a visão do posto de saúde como estrutura fisica que fica a espera de "pacientes" acabou e que o que se pretende agora é procurar atender as comunidades conforme houver notificação, $o$ trabalho de ponta é muito importante para esse desenvolvimento, sendo assim o CG 
trará as ações que serão discutidas ou votadas para ordem de prioridade para serem atendidas (ATA $N^{0} 24$, p. 23/ 1995).

Lideranças se dispuseram a aprender e auxiliar o CG, mas precisavam de esclarecimento sobre o que é, de fato, o CG (ATA).

De acordo com o proposto, passo a apresentar as demandas nos desdobramentos respectivos

\section{QUEIXAS DO CONSELHO GESTOR DE SAÚdE DO CRS "Dr. GUINTER HANS" - B. NOVA BAHIA - DISTRITO NORTE - $1994 / 2002$}

\section{SITUAÇÃo EPIDEMIOLÓGICA}

Um buraco, conseqüente de erosão, e ruas em desnivel, contribuíam para a água da chuva $e$ areia invadirem as casas. Fossas rasas enchiam rapidamente e o esgoto a céu aberto era canalizado para a rua. Acúmulo de água e lixo traziam aumento de moscas, mosquitos e outros bichos. Crianças nadavam nessas águas e tinham febre e diarréia constantes (ATAS). Ainda, reclamavam de bueiros sem tampa e alta incidência de bicho-de-pé. Esta queixa era no fim da primavera. Com muito calor as crianças andam muito descalças. Neste mês, a temperatura média nos horários mais quentes é de $30^{\circ} \mathrm{C}$.

O CG dizia que as condições de higiene do CRS eram comprometedoras e a água estava contaminada. Os conselheiros foram notificados da existência de lixo hospitalar, encontrado em colônia e pediam orientação quanto à origem dos materiais. Fala-se em reduzida colaboração da população na eliminação dos focos da dengue. $\mathrm{O}$ mutirão de limpeza dos bairros é realizado pela população e por agentes do PACS. Mas estes reclamavam que não é era sua função recolher lixo nos terrenos baldios (ATAS). 


\section{SERVIÇOS DE SAÚDE}

A segurança do CRS vinha sendo alvo de preocupação devido, inclusive, a atos de vandalismo e agressões de usuários na Unidade. Queriam muito algumas mudanças na infra-estrutura que viessem dar mais segurança aos usuários.

Tinha-se reclamações em relação aos recursos humanos: falta de funcionários; reclamação do cardiologista; funcionários com falta de atenção e mal educados na recepção; faltava clinico geral e medicamentos; falta de auxiliares e zeladores; demora no atendimento do plantão e dificuldades de médicos para plantões; má vontade de alguns funcionários no acolhimento e de médicos, no atendimento; falta de pediatra no 24 hs. e não tinha escala de médicos em Jan/Fev/97 no CRS. O técnico de RX do Hospital Dia tinha salário baixo e a carga horária era de $8 h$. (ATAS). Aliás, o CRS ficou sem técnico de RX por um bom tempo.

Os usuários consideravam que a atenção primária era paliativa e não resolvia a maioria dos problemas, que a atenção ao câncer de próstata pela rede, demora em realizar exames; baixa qualidade dos materiais do ambulatório. Quanto ao CRS, não se conseguia serviço especializado emergencial, a ambulância dificilmente era liberada, não se tinha controle do Ultrasson, por região, no CEM, demora para atender os pacientes no 24 h., e ausência de bebedouro na UBS, por vandalismo, eram críticas registradas (ATAS). A Diretora da UBS também reclamava da escassez de funcionários, pois não há substituição nas férias e nem por doença, trazendo acúmulo de atividades dos trabalhadores. Tais queixas parecem ter procedência, pois eram atendidos 60 clientes em 6 horas! É muito atendimento numa Unidade de urgência/emergência com reduzido número de funcionários.

A distância da população de um dos bairros da área de abrangência do CRS dificultava o acesso para vacinação e, reclamavam ainda, que as Diretoras do ambulatório e do CRS não se empenhavam nas atividades de odontologia $e$ aparelho odontológico estava estragado. Muitas pessoas queriam o tratamento odontológico, mas abriam-se vagas uma vez por mês e isto era constantemente criticado (ATAS). 
Um usuário interferia no andamento das funções da UBS, dificultava e conturbava o ambiente, oferecendo riscos e interrompendo a rotina da UBS, com transtornos nas filas e várias receitas para adquirir remédios na farmácia (ATAS).

\section{SETOR SAÚDE}

As eleições municipais (out./95) prejudicaram as reuniões. Representantes das comunidades envolvidas se tornaram cabos eleitorais, culminando em reuniões sem quorum.

A população reclamava que o trabalho do setor saúde era burocrático e centralizado e existiam ações desarticuladas com outras Secretarias. A Secretaria de Serviços e Obras Públicas - SESOP - não podia atender mutirão da DENGUE. Existiam, ainda, dificuldades para agendamento no CEM e nem todas as creches tinham médico - só a do Parque dos Poderes (ATAS).

Os usuários não conhecem muito bem o funcionamento do CG e uma parcela pequena da população participa. Sentia-se a ausência de conselheiros usuários. Poucos conselheiros compareciam às reuniões e tem dificuldade para pensar no coletivo (conselheiro trabalhador). Fatos desagradáveis surgiram entre líderes comunitários e agentes do PACS. E, para piorar, um escândalo médico. Ainda reclamavam que as decisões tomadas no CG não estavam sendo respeitadas, que o individualismo é um ponto negativo no funcionamento do CG e faltavam respostas às questões colocadas (ATAS).

Era solicitado fazer valer o RI. Maior representatividade dos usuários no CG era uma tônica freqüente. Uma Conselheira cobrava da SESAU composição com paridade no CG (11/8/95). Pedia-se empenho dos usuários para divulgar ações, profissionais e Programas do CRS, bem como multiplicadores para informações contra drogas. Pediam, ainda, a presença de técnico da FUNASA, em reunião com a comunidade, ajuda da Pastoral para o CG e a presença do Secretário de Saúde para apoiar o Conselho. Os profissionais de saúde deveriam trabalhar com os lideres dos 
bairros. Pediam, também, que secretarias afins da saude estivessem nas reuniões do $C G$ (ATAS).

O CG solicitava as deliberações do CMS no intuito de acompanhar os encaminhamentos, dos quais, alguns dependiam, finalmente, de decisões desse Conselho. Era solicitada, através de Oficio da SESAU, a presença de representantes do CG para reunião e fazer parte da comissão municipal da AIDS, autorização para instalar CIPA no CRS, cascalho para o pátio da Unidade, mas foi negado por falta de material. Os conselheiros pediam a Cartilha da FUNASA sobre saúde pública para as escolas (ATAS).

Pediram para a TELEMS reinstalar orelhão dentro da Unidade; para a SESOP, postes com luminárias para o pátio do CRS e um levantamento de dados para ver o tipo de atendimento das creches.

Em março de 2001 pediram, também, ao Controle Social da SESAU formação de conselheiros. O pedido foi aceito. Em 15/4/2001, foi solicitado encaminhar prioridades do CG para serem incluidas na minuta do Projeto de Lei e, em 15/12/2002, pediram a presença do sindicato dos médicos na reunião ordinária do CG. Um conselheiro pedia empenho dos conselheiros na resolução dos encaminhamentos e participação da UBS (ATAS).

A Diretora do CRS pedia curso para conselheiros à SESAU. A SESAU pedia que os conselheiros participassem de Oficina antes das Conferências Distritais, em fev./95, e que estivessem todos presentes na Conferência, pois teria temas importantes para as politicas de saúde (ATAS).

\section{SUGESTÕES DO CONSELHO GESTOR DE SAÚDE DO CENTRO DE SAÚDE “DR. GUINTER HANS” - BAIRRO N. BAHIA - Campo Grande/MS - 1994/2001}




\section{SITUAÇÃO EPIDEMIOLÓGICA}

Os conselheiros pediam análise da água do CRS. Pediam para fechar a Unidade de Saúde para tratar da água e deslocar o atendimento para outra Unidade. Solicitado Inquérito sobre saneamento básico e apreensão de cães. Também pediram à Vigilância Sanitária para solicitar a uma loja de pneus para cuidar dos pneus no intuito de evitar a Dengue e recolhimento de lixo o qual estava sendo feita de maneira incorreta. A Diretora da UBS solicitava parceria de todos contra a Dengue, maior autoridade dos agentes PACS em relação a Dengue pois o índice está muito alto com ações de palestra e tira dúvidas sobre dengue com servidores da FUNASA com orientações para notificação, sintomas, exame e modo de transmissão (transmissão ovariana). Deveriam encaminhar representantes do CG e da comunidade, para o Comitê Municipal contra Dengue para discutir estratégias de combate. Também, atenção para o problema da leishmaniose e projeto para reposição de tampas de caixas descobertas (ATAS).

O ano de 2002, apresentou uma dinâmica intensa. Sugeriram ação de mobilização no combate à dengue. A SEMUR e a Vigilância Sanitária fariam esclarecimentos e orientações e teriam como convidados as comunidades, igrejas, escolas e lideranças da região. As entidades promoveriam gincana, poesias, cartazes, teatros, músicas, anti-dengue. Ainda, divulgar na mídia os mutirões de limpeza e distribuir sacos de lixo para feirantes (ATAS).

O CG lembra sempre aos conselheiros e líderes comunitários que ajudem na divulgação das campanhas de vacinação, hipertenso, Hansen, dia da Mama, prevenção da AIDS, através de Folder e palestras de prevenção do câncer de colo uterino, de mama e de próstata, sobre o PACS, teste pezinho, campanhas de gripe para idosos e de diabéticos para detectar novos casos, dentre outros. $\mathrm{O}$ atendimento odontológico é assunto sempre presente nas Atas.

Pediam providências quanto a uma creche, pois as crianças estavam constantemente com diarréias, pneumonia e desnutridas; para indústria de mármore e ardósia, pois despejam resíduos na rua, e o lixo da feira não é acondicionado. Solicitavam esgoto. 
A reforma da Unidade era defendida por um Vereador, ex-Secretário da Saúde de Campo Grande/MS, e a direção do CRS pedia apoio do CG para se equipar adequadamente o RX no Hospital Dia (ATAS).

\section{SERVIÇOS DE SAÚDE}

Os Programas oferecidos pela Unidade necessitam ser mais conhecidos da população. A sugestão de conserto do muro (mar./94) e grades na frente do ambulatório para evitar depredações, furtos e pessoas suspeitas no CRS ( pois só existiam mulheres) era aceita por todos. Era necessário, também, para dar segurança aos usuários e crianças (ATAS).

Treinamento para enfermeiros em emergência hospitalar pela UFMS, compra de equipamentos para emergência e medicamentos para hipertensos, formação para conselheiros usuários sobre a rotina de atividades do CRS, de 3 em 3 meses, concurso para agentes do PACS, aberto a todos, eram necessidades sentidas por esse CRS.

Era solicitado serviço social para a comunidade, que o médico pediatra atendesse qualquer pessoa, se preciso fosse, plantão odontológico no periodo de 18-24 h. para os usuários trabalhadores, contratação de auxiliar administrativo e aumento no quadro de pediatras (fev./98). Reivindicavam, ainda, carro para melhor desenvolvimento dos serviços de saúde, complemento salarial para técnico $R X$, pois era o único na rede do municipio, e telefone para o CRS para facilitar a informatização. Pediam prioridade ao programa dos idosos, informações sobre as funções da UBS para colaborar na comunidade, divulgar vacinas para crianças $e$ adultos, vacina contra a febre amarela, implementar a discussão preventiva e o PSF (ATAS).

Afixar quadros de relação de médicos e plantonistas nas recepções e cartazes para os usuários, com explicações e relações de médicos, era uma proposta respaldada pelos conselheiros. Sugeriram, ainda, visita dos médicos nos domicílios, a exemplo do PSF, no Ceará (ATAS). 
Tem-se nos registros das Atas, a expressão reordenamento dos serviços, várias vezes. Aliás, formou-se uma comissão para estudar esta proposta. Este reordenamento era desejado em nov./94 para 1995, principalmente, em relação aos recursos humanos. Uma comissão elaborou um relatório da proposta. Uma caixa de sugestões deveria ser colocada no CRS. Ainda, a implantação do plantão odontológico, letreiro luminoso e placas na BR para localizar a entrada da Unidade 24h.; implantação da pós-consulta e com orientações aos usuários, mais vagas para exames e melhorar o sistema de agendamento na UBS - marcar consultas em outro horário que não fosse cedo, por exemplo, às 12h. Ainda, melhorar o cartão de retorno do paciente, solicitar para a SESAU, oftalmologista para o ambulatório e serviço social para atender, na comunidade, pessoas que realmente precisava (gestantes, mulheres e crianças), mediante calendário elaborado pelos lideres comunitários. E também, divulgação sobre Hansen nas escolas e nas contas de água e luz. Aliás, a Secretaria de Saúde começou a informar sobre Hansen nos ônibus urbanos (busdoor).

Poderia se pensar em panfletos e cursos para senhoras voluntárias. A Unidade de Saúde deveria atuar na prevenção (dez./95) e orientar a população para uso correto da Unidade 24h. Os acadêmicos de Enfermagem da UFMS pediam maior divulgação dos Programas de Saúde; levar equipes de vacinação para fazendas $e$ maior divulgação do Sistema de Vigilância Alimentar e Nutricional - SISVAN. Propunham, também, a partir de meados de 2001, criar ouvidoria na UBS, mais vagas para pequenas cirurgias: dois dias com 6 h., num total de 64 consultas por semana, com agenda semanal; senhas para agendamento de especialidades no CEM; especialidade de ortopediatria; exames de RX geral para a UBS; terapia de grupo para funcionários e encaminhar Oficio à SESAU, elogiando o trabalho da Diretora da UBS (ATAS - QUESTIONÁRIO).

Usuários pediam que o CG interviesse quanto ao bebedouro do terminal urbano, explicação sobre agendamento no CEM e fila da UBS, liberação de banheiro feminino, limpeza de banheiros, bancos com encosto no CRS. A Diretora do CRS explicava que pediu, no planejamento para 2003, encosto para bancos, para melhorar 
a acolhida dos usuários, a comunicação entre os usuários e trabalhadores e reduzir a ansiedade dos usuários. Pediu, também, ampliação da sala de espera do CRS e reforma da sala de inalação. Pedia, agora, aos conselheiros, empenho para a campanha de vacinação e ajuda de todos quanto à leishmaniose. Quanto aos recursos humanos, pediam encaminhar funcionários do PACS e do PSF para fazerem formação para o bom desempenho da Unidade (ATAS).

Os conselheiros esperam a ampliação da UBS do Nova Bahia, as conferências de saúde (aconteceram em julho/03), melhorias no atendimento, esclarecimentos aos usuários e funcionários sobre os direitos e deveres de cada um. Sugerem, também, colocar direitos dos usuários em cartaz, no 24 h., pois já tem direitos dos trabalhadores (ATAS).

\section{SETOR SAÚDE}

O Regimento deveria ser elaborado com sugestões de todos (jan/94). Com 3 semanas, foi lida a versão provisória do Regimento Interno. As Comunidades deveriam assumir tarefas para não sobrecarregar uma só pessoa. Cada bairro deveria avaliar as atividades da Unidade e passar para o CG.

Um documento com todos os pedidos e assinados pelos lideres, reuniões com comunidades para conhecer suas necessidades, necessidade de o CG politizar a comunidade, engajamento de acadêmicos de Enfermagem para apoiar a comunidade, estagiários de direito nos serviços de saúde do trabalhador e arrumar veículo para visitação das lideranças foram sugestões colocadas para sensibilizar a população dos bairros a entenderem melhor o funcionamento do CRS. Mas era preciso, também, sensibilizar os servidores da SESAU. Mandariam cópias das Atas para finalizar a solução dos problemas e relatório das coisas não realizadas: grade na frente do CRS, pedras para o pátio e estacionamento, campanha da sobras de remédios, guarda diurno, visita do Secretário de Saúde ao CRS para motivar as lideranças, treinamento de atendimento ao público para funcionários, contratação de médico clínico geral, reuniões na comunidade, melhoria do orelhão comunitário e retirada 
de out-door de frente da Unidade. Mais que isto, encaminhariam as Atas do CG para o Conselho Municipal de Saude - CMS (ATAS).

Os conselheiros afirmavam que o CG é o direito e conquista da comunidade usuária (jan./95). Propunham, então, reuniões com todos os $C G$, com usuários e funcionários, para integração, troca de experiências e articulações que viabilizassem as solicitações e os encaminhamentos. Uma estratégia utilizada foi convocar os líderes de bairros para a nova eleição e aumentar o número de conselheiros. Advogava-se a integração dos serviços de saúde com instituições diversas.

Da eleição de 15/12/01, foi dada posse aos conselheiros em $31 / 01 / 02$, pela Diretora do Distrito Norte. A escolha da coordenação do CG foi um dos assuntos que foi discutido com muito cuidado e seriedade, pois na avaliação do grupo gestor a ausência do coordenador interfere diretamente no andamento das ações e atividades (Atas, p. 54). O coordenador foi indicado pelos conselheiros. O Diretor Distrital manifestava, nesta ocasião, anseio de ver ampliadas as representações dentro do $C G$, distinguindo do movimento comunitário e da política partidária. O cargo é de relevância pública (ATA). A representação na PLANURB é direito e necessidade de todos os CG, mas é preciso que estejam registrados em Cartório (ATAS).

Sugeriram oficina de trabalho para melhorar atendimento realizado pelo Distrito, oficina de CG para todos os agentes e grupos de estudo com a comunidade, divulgando o que é controle social - em jornais comunitários - sensibilizando usuários e trabalhadores sobre o CG, buscando maior empenho dos conselheiros. Deveriam, ainda, criar uma ouvidoria para fiscalizar o andamento dos Ofícios enviados para as entidades e às secretarias. A substituição de conselheiros deveria ser feita de acordo com critérios do Regimento. Oficina de capacitação era sentida como necessidade (ATAS). 


\section{QUADRO 02 - DECISÕES/ENCAMINHAMENTOS DO CONSELHO GESTOR DE SAÚDE DO CRS “Dr. GUINTER HANS" - B. NOVA BAHIA - DISTRITO NORTE - 1994/2002}

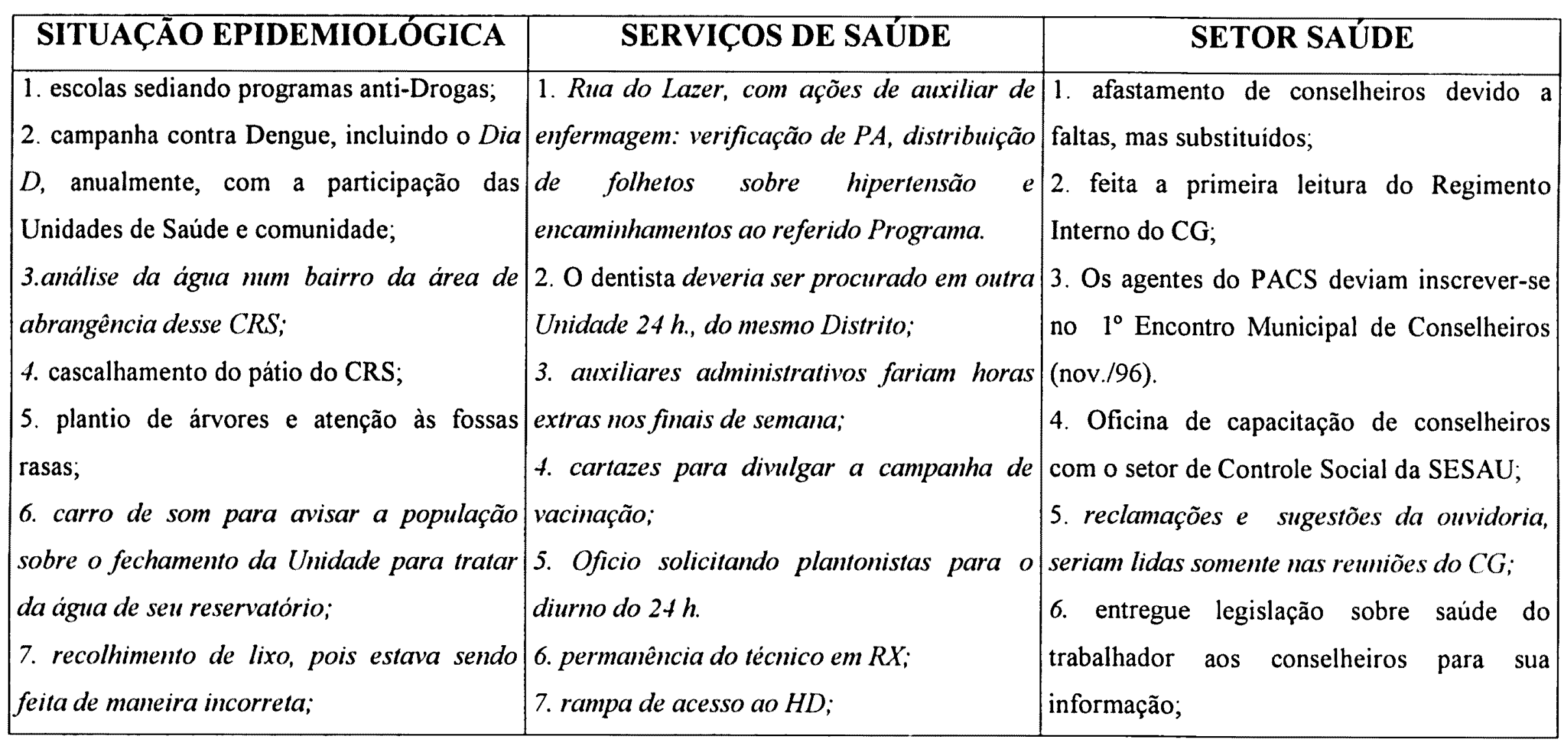




\begin{tabular}{|c|c|c|}
\hline $\begin{array}{l}\text { ixo na Unidade. } \\
\text { mpedir que as águas pluviais invadissem as } \\
\text { esidências próximas; } \\
\text { 0. extermínio dos pombos; } \\
\text { 1. Palestras sobre hipertensão, pelos } \\
\text { rabalhadores de saúde; } \\
\text { 2. visitação das casas, pela FUNASA, para } \\
\text { er as fossas rasas com esgotamento na rua; }\end{array}$ & $\begin{array}{l}\text { ser reparado; } \\
\text { 14. estudar a melhor forma de agendamento; } \\
\text { 15. treinamento com mulheres voluntárias } \\
\text { para desenvolverem trabalho na comunidade } \\
\text { e na UBS; } \\
\text { 16. fazer ouvidoria nas filas; }\end{array}$ & $\begin{array}{l}\text { 11. equipe de Educação em Saúde deveria } \\
\text { esclarecer dividas dos conselheiros } e \\
\text { assessorar reuniões; } \\
\text { 12.Folhetos explicativos sobre urgência e } \\
\text { emergência e agendamento para CEM } \\
\text { deveriam ser confeccionados pela equipe do } \\
\text { setor de Controle Social da SESAU; }\end{array}$ \\
\hline
\end{tabular}




\begin{tabular}{|c|c|c|}
\hline $\begin{array}{l}\text { 17. pesquisa sobre Tuberculose, pois houve } \\
\text { aumento considerável de casos mais graves; } \\
\text { 18. comissão para visitar o lixão próximo ao } \\
\text { CRS, para conhecer e avaliar o problema; }\end{array}$ & $\begin{array}{l}\text { para o PSF; } \\
\text { 18. especialidade no CEM; } \\
\text { 18. aumentar nimero de médicos; } \\
\text { 19. falar ao CG sobre o PACS; } \\
\text { 20. pedido mais um mirim para agilizar } \\
\text { atendimento. } \\
\text { 21. conselheiro faria cartaz explicando as } \\
\text { atividades no } 24 \text { h. } \\
\text { 22. conselheiros conheceriam a rotina do } 24 \\
\text { hs.; } \\
\text { 23. as Diretoras da UBS e do CRS deveriam } \\
\text { auxiliar nas dificuldades de difícil solução; } \\
\text { 24. TELEMS reinstalar orelhão dentro da } \\
\text { Unidade; } \\
\text { 25. SESOP instalar postes com luminárias } \\
\text { para pátio do CRS. }\end{array}$ & $\begin{array}{l}\text { com antecedência, para que se explicasse o } \\
\text { que é e como funcionava o CG, seu } \\
\text { Regimento, mas, com reunião nos bairros, } \\
\text { anteriormente; } \\
\text { 14. convites aos representantes das } \\
\text { comunidades para as novas eleições; } \\
\text { 15. em desistência, o conselheiro deveria } \\
\text { formalizar sua desistência e indicar o } \\
\text { substituto que representasse sua entidade ou } \\
\text { desistisse para outra entidade; } \\
\text { 16 divulgação do CG em programas } \\
\text { populares na T; } \\
\text { 17. Oficios para lideres comunitários, além } \\
\text { de divulgação na rádio da FUNLEC, sobre o } \\
\text { CG; } \\
\text { 18. matéria para o Boletim do Controle } \\
\text { Social da SESAU; } \\
\text { 19. Oficio pedindo divulgação, na midia, do } \\
\text { SISVAN e da importância do CG e }\end{array}$ \\
\hline
\end{tabular}




\begin{tabular}{|l|l|l|}
\hline & $\begin{array}{l}\text { notifícando a falta de técnicos em radiologia } \\
\text { no Hospital-Dia; } \\
20 . \text { Esclarecimentos sobre orçamento foram } \\
\text { feitos e aprovado por consenso de todos. } \\
21 \text { abaixo-assinado, acompanhado de Oficio } \\
\text { para DNER, solicitando a colocação de } \\
\text { redutor de velocidade na esquina e estrutura } \\
\text { de Retorno, em frente ao CRS, para facilitar } \\
\text { o trânsito no sentido bairro-centro, além de } \\
\text { construção de quebra-molas em frente a } \\
\text { Unidade; } \\
22 . \text { comissão para relatar acidentes, fluxo, } \\
\text { velocidade dos veiculos e animais mortos na } \\
\text { pista; } \\
23 . \text { buscar, com o Corpo de Bombeiros, } \\
\text { dados estatisticos dos acidentes no local do } \\
\text { CRS; } \\
24 . \quad \text { Oficio para DETRAN e Conselho } \\
\text { Regional desse CRS para construção de }\end{array}$
\end{tabular}




\begin{tabular}{|l|l|l|}
\hline & & $\begin{array}{l}\text { passarela de pedestres; } \\
25 . \text { Oficio solicitando iluminação na BR, } \\
\text { abrigo de ônibus e guardas fardados (PM), } \\
\text { no CRS. }\end{array}$ \\
\hline
\end{tabular}

Quando perguntado aos conselheiros sobre a capacidade de decisão responderam ser mínima, só é consultivo, de sugestão. O canal facilitador para se efetivar as decisões é o coordenador do CG em conjunto com a diretora da Unidade. Não há resistência para o avanço da proposta do controle social e os aliados vêm sendo Conselho Distrital e direção da Unidade, através do diálogo e reuniões abertas. Os encaminhamentos do CG se fazem via Ofício e/ou visitas de conselheiros a instituições. 


\section{AVANÇOS E CONQUISTAS IDENTIFICADAS NOS REGISTROS NO PERÍODO DE ESTUDO - CRS "Dr. GÜINTER HANS" - B. NOVA BAHIA - DISTRITO NORTE - 1994/2002}

1. a limpeza passou a ser terceirizada em set./98;

2. elogios para o serviço de triagem e para os baixos índices de câncer de colo de útero;

3. o CRS ganhou jardim com flores coloridas;

4. a FUNASA realizou pesquisas domiciliares e perfil epidemiológico do Distrito;

5. feita contratação de médico para o turno vespertino, depois de 45 dias de queixa;

6. em março de 1994, foi realizado concurso público para médicos e funcionários;

7. implantação do serviço de atendimento especializado, para HIV/AIDS; mais tarde, este serviço se transformaria no Hospital-Dia (HD), funcionando hoje na mesma estrutura do CRS, mas com outra gerência;

8. novos funcionários foram lotados no Distrito e no CRS e o atendimento de oftalmologia passava a ser realizado pelo Hospital São Julião - referência do Distrito Norte ${ }^{1}$;

9. ampliação do quadro de funcionários, dinamização do atendimento;

10. implantados os Programas PAISC e PAISM na UBS Mata do Jacinto - Unidade do Distrito Norte (11/94);

11. o HD passava a atender, também, doenças parasitárias com medicamentos e atenção que não requerem internação;

12. ações de educação em saúde, em alguns bairros, com mobilização comunitária e divulgação começaram a acontecer;

13. o Distrito fez treinamento com funcionários administrativos para melhorar o atendimento e foi elaborado Folder explicativo sobre atendimento do CRS;

14. um médico passou a atuar junto aos médicos em cada Distrito;

15. todos os profissionais da enfermagem tiveram treinamento em normas e rotinas de atendimento e o CRS ganhou Ultrassom e mais um clínico geral;

16. conforme solicitado, foi construída a infra-estrutura para PSF em um dos bairros da área de abrangência do CRS;

17. tem-se avanços no agendamento da odontologia e de médicos e encaminhamentos; 
18. A Coordenadoria de Saúde Coletiva tomou providências para águas servidas, três meses depois da reclamação, em set./97;

19. a SESOP visitou o CRS para fiscalizar problemas, notificado o CG em 29/04/98;

20. maior interesse dos conselheiros nas políticas de saúde, parcerias nas decisões da Unidade de Saúde e melhoria no atendimento;

21. por persistência e insistência aconteceram melhorias na estrutura da Unidade e execução de ações do SUS;

22. defendem a compreensão, a capacidade de ajudar ao máximo;

23. com um mês e meio de funcionamento do Conselho, já se lia o Regimento provisório e se elegia o coordenador e a secretária do CG mas, somente depois de 20 meses, tinhase a aprovação do Regimento Interno dos CG pelo CMS;

24. o agendamento de consultas das creches municipais, com o devido atendimento na Unidade, ficou garantido pelo $\mathrm{CG}$;

25. foi realizado um Projeto pela FUNASA para a melhoria do saneamento básico, traçando o perfil epidemiológico com visitas domiciliares e priorizados os bairros com problemas mais graves;

26. Também avançaram no amadurecimento das idéias, no aprimoramento dos conhecimentos do CG, na consciência dos conselheiros;

27. Em 2002, formava-se o Conselho Distrital com a composição 4:1:1 (Atas-questionário).

\section{Posto estes fatos, posso caracterizar este CG da seguinte forma:}

CG criado há oito anos; com cinco pausas: em 1994: 98 dias; 1995: duas vezes de 90 dias; em 1998: 110 dias; em 1999: 19 meses; em 2000: 14 meses; com dinâmica mais estável a partir de 1999, com dinâmica mais estável a partir de 2001, com reuniões agendadas através de um calendário de reuniões, de conhecimento de todos os conselheiros e dirigidas pelo(a) coordenador(a) do Conselho. $O$ processo de trabalho se desenvolve a partir das temáticas postas, das necessidades, seguindo, normalmente a seqüência reivindicações - sugestões decisão - encaminhamentos; sugestões - novas - discussões -decisão - encaminhamentos; reivindicações - decisão - encaminhamentos; teve paridade alterada de 3:2:2 para 4:2:2, para $2: 2: 1$, para $4: 2: 2$ e, finalmente, a exemplo de todos os CRS, para 8:4:4; a

\footnotetext{
${ }^{1}$ O Hospital São Julião é filantrópico, com especialidade em HANSEN.
} 
representatividade da população se dá pelas entidades de associações de bairro, usuários, escolas, clubes de mães, associação de pais e mestres e pastores. Os trabalhadores se expressam mais pelo corpo de enfermagem pelos agentes do PACS e os prestadores de serviços, pelos chefes de Unidades e da SESAU; não existe pauta pré-divulgada ou agendada de maneira coletiva, anteriormente, ou seja, as discussões vão se dando na direção das questões levantadas pelos conselheiros ou solicitadas pela chefe da Unidade, do Distrito e/ou SESAU; as decisões e os encaminhamentos não garantem a consecução das ações; participação da comunidade e surgimento de novas lideranças; usam a mídia para chamar a atenção da necessidade de se compor o $\mathrm{CG}$; quem mais participa são os conselheiros mais antigos e a gerente da UBS; relacionam-se de forma educada, mas com firmeza; o clientelismo na marcação de consultas incomoda alguns conselheiros usuários; sentem-se impotentes diante de determinados assuntos e problemas. As questões levantadas são necessidades sentidas, normalmente, da população, manifestadas pelos conselheiros usuários, mas que também alcançam níveis de preocupação dos conselheiros trabalhadores e prestadores. As variadas desinformações do segmento usuários, muitas vezes, causam situações de impasse nas reuniões.

As demandas, objetivamente, voltam-se, de acordo com as categorias de Diagnóstico de TESTA, para:

A situação epidemiológica aponta para questões ambientais: água, saneamento e o lixão. Dizem os conselheiros que sujeira chama sujeira. É preciso um programa de promoção da saúde para sensibilizar a população de que todos devem cuidar do destino do lixo, mas se a Prefeitura der mais assistência, não fica lixo prá chamar outro. Dizem, ainda, que onde tem asfalto, a Prefeitura limpa o terreno e manda o débito para o dono, mas onde não tem asfalto, demora limpar. Usuários que conhecem o bairro afirmam que são terrenos de especulação imobiliária, são de burguês que não moram aqui e não estão preocupados com a necessidade de reduzir os indices da dengue. O Comitê da Dengue se reúne mensalmente e, depois de trabalho acirrado o ano todo, os índices da dengue estão mais baixos que no mesmo periodo do ano passado. São realizadas reuniões na comunidade, visitas para suspeitos, sorologia para diagnóstico suspeito e casos confirmados na UBS. 
O perfil epidemiológico do Distrito foi alvo de pesquisa mas não interfere, ainda, no modelo assistencial. Aliás, alguns elementos importantes para um diagnóstico administrativo e estratégico ainda não estão completos. As situações de risco aparecem, principalmente, voltadas para as crianças que utilizam as águas da chuva para brincarem. $\mathrm{O}$ processo saúde-doença vem sendo colocado, ainda, na perspectiva da assistência, pois afirmaram que a atenção primária é paleativa, haja vista que, ainda hoje, a maioria dos matriculados nos Programas de hipertenso e de diabético, vêm à UBS para buscar o medicamento. Mas no final de 2002, o discurso de alguns conselheiros começa a se voltar para a valorização do entorno saudável - promoção da saúde.

$\mathrm{Na}$ categoria Serviços de Saúde têm-se uma ênfase na atenção básica, aos vários Programas (PAISC, PAISM, climatério, ICCN, Planejamento Familiar, Diabético, Hipertenso, Gestante) e campanhas oferecidas na UBS e na variedade e disponibilidade dos médicos nos plantões. PACS, atendimento odontológico, acolhimento, desencontros nos relacionamentos usuários-funcionários são preocupações constantes. Como em todos os CRS estudados, as questões de agendamento de consultas, exames na Unidade e no CEM estão, também, sempre em debate. Existe o desejo de treinamento, tanto para funcionários quanto às rotinas dos serviços. A qualidade do atendimento e o uso da ambulância são, freqüentemente, alvos de crítica. A segurança e a facilidade no acesso aos serviços foram aspectos alvos de ações intersetoriais junto ao DETRAN/DNER. Há um desejo, fortemente, aparente de se lotar, na Unidade, funcionários na área de serviço social para dar orientação à população quanto ao acesso e ao uso dos serviços disponíveis, bem como ajudar nos encaminhamentos assistenciais. A demanda espontânea é a lógica do atendimento e dos debates, indicando carência da atenção ambulatorial e de urgência. Campanhas de vacinação e Programas são parte integrante do processo preventivo.

Quanto ao Setor Saúde, o CG está atento às substituições necessárias de conselheiros, envolvimento e maior politização da população e com a representatividade dos usuários. Existem várias reivindicações para treinamento para conselheiros quanto a função de gestão. A paridade vem sendo legitimada e sentem a necessidade de sensibilizar os servidores da SESAU quanto à dinâmica do CG. A mídia foi buscada como estratégia de 
divulgação das atividades do Conselho e uma ação junto ao DETRAN foi muito intensa, conseguindo alterar a geografia do acesso ao CRS, garantindo aos usuários facilidade e segurança no acesso aos serviços. Até 2002 as questões orçamentárias vinham para o CG para informação e não para acompanhamento e controle. Quanto às questões do planejamento municipal, desde 1999 vem aparecendo, nas Atas, referências à participação do CG no processo, mas somente em 2002 este procedimento realmente ocorreu de maneira ascendente. As demandas dos $\mathrm{CG}$ foram incorporadas.

Tais aspectos denotam que o CG está voltado, de acordo com os elementos de diagnóstico de TESTA (1986 apud SÁ, 1992, p. 43-44), de uma forma decrescente, para as categorias Serviços de Saúde, Setor Saúde e Situação Epidemiológica, e, predominantemente, para a modalidade Administrativo.

Transponho para o referencial do ILPES/CLAPS/OMS (1975), as decisões/deliberações e encaminhamentos, com vistas a identificar os componentes básicos do processo decisório do Conselho. Temos o seguinte cenário:

QUADRO 03 - Classificação das decisões/encaminhamentos do Conselho do CRS "Dr. Güinter Hans" - Campo Grande/M.S - 2002, de acordo com referencial ILPES/CLAPS (1975)

\begin{tabular}{|l|l|c|}
\hline CATEGORIA & ELEMENTO & $\%$ \\
\hline Nivel Político & $\begin{array}{l}\text { Implantação de Programas; } \\
\text { Oficio para construção de área fisica para o PSF; } \\
\text { Oficio ao CMS pedindo divulgação, na mídia, do SISVAN e da } \\
\text { importância do CG; } \\
\text { recolhimento correto de lixo nos bairros; } \\
\text { visitação das casas, pela FUNASA, para ver as fossas rasas com } \\
\text { esgotamento na rua; } \\
\text { Oficio à Vigilância Sanitária sobre águas servidas; }\end{array}$ & $\mathbf{2 4 , 2}$ \\
\hline
\end{tabular}




\begin{tabular}{|l|l|}
\hline Oficio para juizado da infầncia sobre o acesso das pessoas ao \\
lixão; \\
reunião na comunidade, com profissionais da Unidade de \\
Saúde, para orientações quanto ao preventivo de câncer, \\
importância do SUS e do CG; \\
reunião de líderes para decidirem quais as reivindicações seriam \\
feitas na reunião do Projeto do mutirão de limpeza; \\
conselheiros divulgavam o CG em programas populares na TV; \\
Oficio para realização de eleições, as entidades da região \\
seriam convidadas, com antecedência, com reunião nos bairros; \\
Conselheiros encaminharam abaixo-assinado, acompanhado de \\
Oficio, para DNER, para colocação de redutor de velocidade, \\
estrutura de Retorno e construção de quebra-molas em frente à \\
Unidade; \\
Oficio para DETRAN e Conselho Regional desse CRS para \\
construção de passarela de pedestres; \\
iluminação na BR; \\
abrigo de ônibus; \\
e guardas fardados (PM), no CRS. \\
administrativo \\
cascalhamento do pátio do CRS; \\
pantio de árvores; \\
construção de lixeiras no CRS; \\
construção de depósito para lixo na Unidade; \\
exterminio dos pombos no CRS; \\
palestras sobre hipertensão; \\
Projeto do mutirão foi elaborado por uma comissão com dois \\
conselheiros e um trabalhador da FUNASA; \\
pesquisa sobre Tuberculose; \\
auxiliares administrativos fariam horas extras nos finais de \\
semana;
\end{tabular} \mid $\mathbf{5 6 , 1}$


cartazes para divulgar a campanha de vacinação na Unidade; Oficio ao Secretário de Saúde para permanência do técnico em RX;

rampa de acesso ao $\mathrm{HD}$;

trabalho de Educação em Saúde;

caixa de sugestões;

odontologia só iria atender pacientes especiais HIV/AIDS, tuberculose e hepatite;

atendimento do RX seria ampliado para 2 períodos;

muro quebrado da Unidade deveria ser reparado;

estudar a melhor forma de agendamento;

aumentar número de médicos;

Oficio à coordenação do PACS para falar ao CG sobre o PACS; pedido mais um Mirim para agilizar atendimento;

cartaz explicando as atividades no $24 \mathrm{~h}$;

conselheiros conheceriam a rotina do $24 \mathrm{~h}$;

Diretoras da UBS e CRS deveriam auxiliar nas dificuldades de dificil solução;

Oficios à TELEMS para reinstalar orelhão dentro da Unidade e SESOP para colocar postes com luminárias no pátio do CRS;

as creches poderiam agendar consultas e seriam atendidas na Unidade;

Oficio notificando a falta de técnicos em radiologia no HospitalDia;

Conselheiros e as comunidades se envolveram em mutirão de limpeza da área externa e na limpeza do prédio do CRS;

Diretor Distrital deveria localizar lideres nas comunidades e convidá-los para compor o CG;

equipe de Educação em Saúde deveria esclarecer dúvidas dos conselheiros e assessorar reuniões;

folhetos explicativos sobre urgência/emergência, com 


\begin{tabular}{|l|l|}
\hline agendamento para CEM, confeccionados pela equipe do setor \\
de Controle Social da SESAU; \\
Oficio solicitando plantonistas para o diurno do $24 \mathrm{~h}$; \\
as reclamações, sugestões da ouvidoria seriam lidas somente \\
nas reuniões do CG; \\
$\begin{array}{l}\text { Ouvidoria lacrada com cadeado e as chaves ficariam com a } \\
\text { coordenadora do CG; } \\
\text { Reunião extraordinária para discutir a ouvidoria e a oficina para } \\
\text { conselheiros; } \\
\text { carro de som deveria avisar a população sobre o fechamento da } \\
\text { Unidade para tratar da água de seu reservatório. }\end{array}$
\end{tabular} \mid $\mathbf{T = 1 0 0}$

É necessário esclarecer que está se considerando, no político, não o ato de encaminhamento de Oficio, mas o conteúdo deste Oficio.

TABELA 07 - Distribuição numérica dos tipos de decisões tomadas pelo Conselho Gestor de Saúde - Bairro Nova Bahia/Campo Grande - M.S, 1994- 2002

\begin{tabular}{|l|l|l|}
\hline CATEGORIA & NÚMERO & $\%$ \\
\hline Nivel Político & 16 & 24,2 \\
\hline Nivel Técnico-Administrativo & 37 & 56,1 \\
\hline Nivel técnico-Operacional & 13 & 19,7 \\
\hline TOTAL & 66 & 100 \\
\hline
\end{tabular}

Fonte: Atas das reuniões e documentos do CG 
6.2 CONSELHO GESTOR DO CRS “Dr. JOÃO ROSA PIRES” BAIRRO AERO RANCHO - DISTRITO SUL - 1997/2002 
O CG do Centro Regional de Saúde "Dr. João Rosa Pires", do bairro Aero Rancho, iniciou suas atividades com uma assembléia em 27/09/1997 e com apresentação dos presentes pela Diretora do CRS. Foram distribuidos convites pelos representantes comunitários dos bairros de entorno do Aero Rancho - área de abrangência deste CRS. Um dos presentes ${ }^{1}$ esclareceu dúvidas sobre o que é e os objetivos do CG. Alguns afirmavam que quem participar deve ter responsabilidade e não só por bonito, que estavam em regime de votação e que tinha que se ter consciência e seriedade (ATAS).

A Diretora do CRS falava da necessidade de se elaborar o Estatuto do Conselho e sobre o horário das reuniões. Como se tem metas a alcançar, que se marque uma data para discutir o Estatuto e que cada um trouxesse sua proposta. Decidiu-se que a reunião teria uma hora para discutir somente o necessário. Todos os membros presentes (10 funcionários e 15 usuários) chegaram a um consenso de que era preciso ter responsabilidade em relação às reuniões e levar a sério o CG. Foram esclarecidos sobre a campanha de vacinação e as temáticas de discussão começaram a se mostrar (ATA).

A coordenadora do CG foi escolhida entre os usuários e a secretária, uma trabalhadora de saúde. Um usuário explicou as atribuições dessas funções, não relatadas em Ata. Esta Ata foi lavrada no Cartório do $4^{\circ}$ Oficio em 23/03/98 e, então, estava legalizado este Conselho Gestor de Saúde. Depois de 21 dias, fez-se a $2^{a}$ reunião com a apresentação dos conselheiros trabalhadores de saúde.

\subsection{A ASPECTOS DO FUNCIONAMENTO DO CONSELHO GESTOR "Dr. JOÃO ROSA PIRES" - B. AERO RANCHO/DISTRITO SUL 1997 - 2002}

\footnotetext{
${ }^{1} \mathrm{Na}$ Ata $\mathrm{N}^{\circ} 1$ existe o nome deste senhor mas não se diz quem era ele.
} 


\subsection{A.1 PERIODICIDADE DAS REUNIÕES}

No ano de 1997, aconteceram 5 reuniões com periodicidade, variando de 12 a 32 dias reuniões mensais, sendo a primeira reunião registrada em 27/09/97 e, uma delas, extraordinária. O ano de 1998, vivenciou uma longa pausa de 9 meses, com 4 reuniões, sendo a primeira em 06/01 e a $2^{\text {a }}$, extraordinária, em 07/10/98. No ano de 1999 aconteceu uma maior sistematização do funcionamento do $C G$, com 11 reuniões, 4 delas extraordinárias e intervalos variando de 6 a 61 dias. Uma das reuniões, sem quorum, teve a presença da comunidade. Em 2000, foram realizadas 10 reuniões, das quais, uma extraordinária. O CG propôs e realizou reuniões itinerantes para divulgar o trabalho do CG na comunidade. No ano de 2001, o CG se reuniu 3 vezes, com 1 extraordinária, com intervalos de 28 a 35 dias e 5 meses de paralisação. Em 2002, foram 16 reuniões, 3 reuniões extraordinárias com intervalos de 7 a 42 dias e sem paralisação.

TABELA 08 - Periodicidade das reuniões do Conselho Gestor de Saúde do CRS 'Dr. João Rosa Pires - B. Aero Rancho - 1997/2002

\begin{tabular}{|c|c|c|c|c|c|c|}
\hline ANO & $\begin{array}{c}\mathbf{N}^{*} \\
\text { REU } \\
\text { NIÓ } \\
\text { ES }\end{array}$ & $\begin{array}{l}\text { Média } \\
\text { de } n^{*} \\
\text { presente } \\
\text { s }\end{array}$ & $\begin{array}{l}\text { PERIODICI } \\
\text { DADE }\end{array}$ & PARALIZAÇŌES & $\begin{array}{l}\text { Data -eleiç̃o } \\
\text { PARIDADE }\end{array}$ & COORDENADOR(A) \\
\hline 1997 & 5 & 9 & $\begin{array}{l}\text { d2-32 } \\
\text { dias }\end{array}$ & & $\begin{array}{l}27 / 9 \\
4: 2: 2\end{array}$ & Usuário \\
\hline 1998 & 9 & $\begin{array}{l}\overline{\mathbf{N}} \\
\text { registro }\end{array}$ & & 9 meses & & \\
\hline 1999 & 11 & 9 & $\begin{array}{l}6-61 \\
\text { dias }\end{array}$ & $\begin{array}{l}4 \text { reuniões seguidas sem } \\
\text { quorum: } 14 / 708 / 9\end{array}$ & & \\
\hline 2000 & 10 & 16.4 & & $\begin{array}{l}18 / 10 \text { a } 14 / 02 \text { - uma reunião } \\
\text { extraordinária com } 50 \\
\text { pessoas }\end{array}$ & $\begin{array}{l}14 / 6 \\
4: 2: 2\end{array}$ & Usuário \\
\hline 2001 & 3 & 16 & $28-35$ & 5 meses & & \\
\hline 2002 & 16 & 15 & $7-45$ dias & & $\begin{array}{l}8: 4: 4 \text { é } \\
\text { regimental }\end{array}$ & Prestador \\
\hline
\end{tabular}

\subsection{A.2 COMPOSIÇÃO DO CONSELHO GESTOR}


A escolha dos conselheiros usuários aconteceu na $1^{a}$ reunião. Sugeriu-se uma votação para decidir quantos membros teria este Conselho. Com 11 candidatos usuários, decidiu-se por oito membros titulares e oito suplentes numa paridade 8:4:4. Houve um certo tumulto por parte de alguns presentes. Os funcionários se reuniram e elegeram seus representantes. Os eleitos apresentaram seus endereços, número de RG, CIC e telefone.

\subsection{A.3 - REPRESENTATIVIDADE - ATORES}

A representação, nas reuniões, era realizada, além dos conselheiros, também por líderes comunitários, associações de bairros e trabalhadores de saúde. As reuniões eram feitas na capela de uma igreja católica, no salão dos Vicentinos. Depois passaram para uma sala da igreja católica do bairro, reuniões itinerantes, passando a realização das reuniões para o Centro da Mulher (Unidade do Complexo da Unidade), num ambulatório, transformado em sala de reuniões para, aproximadamente, 20 a 25 pessoas.

O Presidente da Associação de moradores não é figura atuante nas reuniões e na busca das soluções para os problemas. A população está representada pelos conselheiros usuários, pois a população propriamente dita raramente comparece. Não existem critérios para a participação das entidades e a definição de vagas. A comunidade é convidada para as reuniões e eleições e a definição dos conselheiros se dá entre os presentes no momento da eleição.

No segmento prestadores de serviços, a representação se faz pelas Diretoras das Unidades do Complexo. O Chefe do Distrito é suplente, mas só comparece quando é convidado. Vigilância Sanitária, Assistente Social e Secretario(a) de Saúde, também, só comparecem quando solicitados. O Setor de Controle Social, ainda, comparece para coordenar eleições e capacitação.

Os trabalhadores de saúde estão representados por profissionais da área da enfermagem e, sem direito a voto, os agentes do PACS, os quais são todos sempre liberados de suas atividades para as reuniões mas, dos 60 agentes da área, aparecem de 10 a 15. Aliás, um dos agentes disse que os agentes não gostam de vir porque atrasa o serviço da área... a 
gente deveria participar...é uma pena, os outros colegas não estarem, pois estamos juntos com a população e é uma ação social. Destes agentes presentes, somente uns $30 \%$ se manifestam nas discussões e, então, a representatividade fica comprometida. Os agentes do PACS têm colaborado bastante para divulgar a existência e a função do CG e convidam a população para estarem nas reuniões.

A Diretora Administrativa do Centro Regional é a atual coordenadora do CG e, junto com os usuários, reitera a importância, os objetivos e a necessidade da participação sistemática dos conselheiros, na divulgação do papel do CG. Conselheiros usuários e prestadores já ocuparam a função de coordenador do CG.

\subsection{B DINÂMICA DO FUNCIONAMENTO DO CONSELHO GESTOR: A PRÁTICA DE ATUAÇÃO DO CONSELHO}

$\mathrm{Na} 2^{\mathrm{a}}$ reunião, os conselheiros foram convidados para o curso do Fórum dos Usuários. Não em todas, mas em muitas reuniões, indicava-se a próxima pauta.

Neste início, as figuras de maior expressão eram a Diretora da Unidade, a Chefe do Distrito e representantes da SESAU, visto o periodo de aprendizado da função de conselheiros. Para a SESAU, este processo já estava um tanto familiar, pois os primeiros conselhos já funcionavam há 3-4 anos nos CRS, e o trabalho de orientação era feito por uma equipe formada com trabalhadores de saúde da SESAU, da FNS, Secretaria de Estado da Saúde e UFMS (Depto. de Saúde Pública). O CG, neste início, conformava-se, predominantemente, em cenário de transmissão de informações e espaço para “palpitações”. 


\section{QUEIXAS REGISTRADAS NAS ATAS DO CONSELHO GESTOR DE SAÚdE DO CRS "Dr. JOÃO PIRES ROSA" B. AERO RANCHO/DISTRITO SUL - 1997/2002}

\section{SERVIÇOS DE SAÚDE}

Uma médica dorm[ia] ao consultar. A população da área de abrangência aumentou e, por isso, não há médicos suficientes para o atendimento. Faltava vagas para ultrasson. Pessoas passavam mal com medicamentos ... o médico se defendia. $O$ atendimento no ambulatório era demorado e funcionários do $24 \mathrm{~h}$. não queriam atender e ficavam lendo ou vendo TV (ATA). Não houve resposta do pedido para clínico geral, de um oficio enviado à Divisão Médica; reunião sem quorum e ... 10 meses de pausa!

$O$ aparelho de Raio $X$ do Centro de Especialidades Médicas - CEM - estava com defeito e havia problemas para marcar exames. Os conselheiros reclamavam que a população não faz[ia] prevenção, só procurava o médico quando piorava e ia para os serviços de urgência. Havia grande número de faltosos às consultas; era preciso melhorar o atendimento e a resolutividade da Unidade. Agentes do PACS não ficaram sabendo de mudanças no Programa de Carências Nutricionais (ATAS).

A Ambulância é sempre alvo de solicitações e questionamentos, havendo orientações para que seu uso se destina[va] a casos extremos, em casa, e deveria ser constatada a realidade da urgência em qualquer demanda. Nem todos os médicos plantonistas ficavam no plantão ou no ambulatório no horário estipulado (nov./98). Um usuário veio a óbito e a imprensa falou que foi a falta de atendimento. Faltavam medicamentos, funcionários e matéria-prima. A farmácia ficava fechada no horário de almoço. Ainda reclamavam da falia de pediatra no $24 \mathrm{~h}$., de preventivos de câncer de mama. $\mathrm{O}$ acolhimento estava comprometido e se reclamava da forma de agendamento. Para pacientes que chegavam doentes só se marcava depois de 15 h. Havia demora na entrega de resultados de preventivo de câncer e poucos laboratórios faziam exames. Os agentes do PACS não estavam atuando devidamente na região e $o$ CG iria averiguar as queixas e abaixo-assinado para afastamento de alguns (ATAS). 
Tinha-se, ainda, como reclamações: a população usa o setor de emergência como ambulatório, agente do PACS não está passando na área e não estão desempenhando seu trabalho; falta de médicos; agendamento de consultas; falta de sala de acolhimento no 24 h., usuário falta à consulta; ausência de profissional pediatra no 24 h., nos finais de semana. Houve concurso, mas poucos pediatras aderem ao serviço de plantão (poucos foram aprovados no concurso público da SESAU). Algumas pessoas depredam a Unidade: roubam torneiras, registros, sifão etc (ATAS).

Dificuldades outras ainda foram colocadas: falta de profissionais de diversos niveis, um usuário cobrava para permanecer na fila e marcar consultas para terceiros (caso já solucionado), falta de consideração de médicos com pacientes; atendimento quanto à coleta exames, mau atendimento da farmácia; não há substituto para profissionais em férias, prejudicando o atendimento. A comunidade é tida como mal educada, com insultos, maus tratos e humilhação aos fimcionários.

\section{SETOR SAÚDE}

$\mathrm{Na}$ pauta para a Conferência Distrital, incluía-se: saúde bucal, saúde do trabalhador, organização de serviços de saúde, nos 3 níveis, Não havia participação de usuários na Conferência Distrital de Saúde. Foi solicitado aos agentes do PACS fazerem relação das entidades da região (ATAS).

Reclamava-se, ainda, que a comunidade não participava nas reuniões do $C G$. Em setembro de 2000, ficava registrado que havia falta de aviso das reuniões do CG. Para a atual coordenadora do CG e, também, gerente da Unidade de Urgência, a população não entende o seu papel e sua força na organização social (ATAS).

Está registrada que a capacitação feita pelo Controle Social da SESAU não veio de encontro com a ansiedade das lideranças. 


\section{SUGESTÕES REGISTRADAS NAS ATAS DO CONSELHO GESTOR DE SAÚDE DO CRS 'Dr. JOÃO PIRES ROSA - B. AERO RANCHO/DISTRITO SUL - 1997/2002}

\section{ASPECTOS EPIDEMIOLÓGICOS}

Elaborar documento solicitando containers para a coleta de lixo, ver possibilidade para dar saco de lixo para moradores e palestras de combate à Dengue nas escolas. Solicitava-se que os agentes do PACS e conselheiros se mobilizassem para criar estratégias para o dia D - campanha contra Aedes. Foi pedido para a Secretaria de Serviços e Obras Públicas - SESOP para limpar terrenos baldios e numa ação conjunta entre moradores e agentes do PACS (ATAS).

Foi solicitada que a UBS deslocasse vacinas para empresa da área do Distrito e avaliasse como estava sendo tratada a água da piscina do Centro de Múltiplas Atividades pela Vigilância Sanitária (ATAS).

\section{SERVIÇOS DE SAÚDE}

A Diretora pedia ao CG despertar a comunidade para lutar por uma UBS em um dos bairros da área de referência do Aero Rancho. Foi proposta de implantação de UBS no bairro Dom Antonio. Uma cartilha sobre o sistema de saúde, feita pela SESAU, estava em apreciação pelo CMS e para uso dos conselheiros (ATAS).

Pedia-se 2 pediatras, 2 ginecologistas e 1 ultrassonologista. Pombos continuavam a fazer ninhos no telhado e se solicitava o fechamento com material mais resistente (ATAS).

Os médicos não deviam receitar remédios não-existentes na farmácia da Unidade e pedia-se um $3^{\circ}$ turno $(17-21$ h.) para ambulatório com permanência de profissional para não sobrecarregar a urgência. A coordenadora do CG sugeria colocar senhas para reduzir a fila de todos os dias para a garantia de vaga. $\mathrm{O}$ usuário daria o número do prontuário para evitar venda das senhas. Os médicos não deveriam sair da Unidade 
sem substituto e era solicitada a implantação do Programa de Diabetes. A Unidade deveria fazer documento, exprimindo cumprimento do horário médico. A fila deveria ser orientada pelos agentes do PACS e o Centro da Mulher deveria atender a partir das 7 hs. Os funcionário deveriam ser treinados para fazer acolhimento e explicar o funcionamento do serviço (ATAS).

Sugeriu-se que os agentes do PACS fizessem marcação de consulta de sua área para prioridade sobre os demais. Os conselheiros não concordaram. Deveriam, ainda, dar folheto aos usuários na sala de espera, com palestras educativas, construção de sala de palestras para mães de crianças desnutridas porque no corredor é[ra] impossivel (ATAS).

Os conselheiros deveriam trazer propostas para atrair pediatras ao serviço, palestras de Educação em Saúde nas entidades da região pelos funcionários, orientando, inclusive, para a conservação do prédio do Complexo de Saúde; lotação de assistente social na Unidade para dar encaminhamentos quanto a problemas sociais que são repassados pelo PACS e psicólogo para dar suporte às familias. A comunidade está cobrando solução. Os agendes do PACS deveriam observar as condições de atendimento médico no CEMA (ATAS).

$O$ agendamento na UBS, sempre voltando à discussão, deveria ser permanente, mas, também, havia proposta para agendar de $3 \mathrm{em} 3$ dias sem horário definido de atendimento. Implantar um sistema de sonorização no ambulatório de $24 \mathrm{~h}$. seria interessante para otimizar o trabalho. Crianças do CEMA deveriam ser atendidas com trabalho de saúde bucal e se sugeria avaliação para ofitalmologia dos alunos de uma escola pública (ATAS).

Quanto à reforma e ampliação geral do Complexo sugeriam: implantação de ortopedia, com RX e gesso, plantonista de especialidades, centro cirúrgico de pequenas cirurgias no $24 \mathrm{hs}$, com vistas a aumentar a capacidade de resolutividade da Unidade, acolher melhor os diabéticos e hipertensos, criar serviço de ultrasson no Centro da Mulher e que esta Unidade controlasse o agendamento; implementação de pré-natal e climatério 
com maior número de profissionais; implantação de $3^{\circ}$ turno de atendimento na UBS, implantar policlínica com serviços de acolhimento no Centro da Mulher e UBS, sala de espera, palestras sobre ações preventivas e implantar o ponto de apoio dos agentes comunitários. Ainda, que a comunidade se mobilizasse para cobrar da SESAU uma resposta para resolver questões dos pediatras; disponibilizasse maior numero de vagas para ultrasson e crachás para funcionários (ATAS).

Ainda, enviar documento para policlínica do Vale do Sol para questionar o trabalho comprado pela SESAU e para dar maior resolutividade nos encaminhamento (ATAS). A Coordenadora do CG solicitava que houvesse empenho por parte dos conselheiros e dos Agentes para formular sugestões alternativas onde tivesse maior envolvimento da comunidade no controle e na prevenção da dengue.

O Centro da Mulher precisava melhorar o atendimento: número de médicos e maior agilidade no atendimento de exames. No 24 h.: profissionais especialistas, melhor trato com usuários na recepção e retirada da senha para facilitar o agendamento. Foi sugerido, em reunião extraordinária, marcar grande reunião com a comunidade $e$ Secretária de Saúde para sensibilizar sobre os serviços de Urgência e completar a escala de médicos no ambulatório. Ainda, implantar Programa de atendimento ao adolescente no Complexo, para 2003 (ATAS - QUESTIONÁRIO).

\section{SETOR SAÚDE}

Era necessário organizar a comissão para novas eleições em 45 dias, encaminhando-se convites às entidades e aos agentes de saúde do PACS. A comunidade deveria ser orientada pelo CG para uso correto da ambulância e a coordenadora afirmava que o CG precisava ter maior poder de resolução para problemas dos serviços de saúde.

Necessidade da criação de ouvidoria, criada através de caixas de sugestões, reclamações e elogios. O reclamante deveria dar nome e endereço para o CG apurar o fato. A coordenadora do CG sugere identificação dos conselheiros para facilitar o acesso à Unidade. 
Algumas necessidades foram colocadas: necessidade de reorganização do CG para melhor otimizar as ações; capacitação de lideranças e tentar comprometê-las, articular com a SESAU para se buscar as lideranças, explicação do funcionamento do Hospital Regional (Hospital de referência para o estado) e disposição para maior integração $e$ afastamento de coordenador devido a sobrecarga de trabalho.

Em novembro de 1997, foi votado estabelecer o número de conselheiros ( 8 conselheiros usuários e 8 suplentes) com paridade 8:4:4. Sentia-se necessidade de elaborar estatuto CG e calendário de horários de reuniões. Em outubro deste mesmo ano, deveriam trazer propostas. Deveriam criar comissão para verificar o funcionamento da Santa Casa, do Hospital Regional - em construção e com atendimento de ambulatório - e o Hospital Universitário. Era solicitada enfermeira do PACS nas reuniões para esclarecer o Programa.

No Planejamento de 2000, reivindicava-se facilitar acesso para usuários de um dos bairros (ainda com UBS não construída), e deveria ter dois agentes do PACS em cada reunião do CG. Sugeria-se a capacitação para conselheiros e os mesmos deveriam participar da Conferência Distrital.

Em setembro de 2000 sentia-se necessidade de oficinas para a capacitação de conselheiros. Foi agendada com SESAU para conselheiros e suplentes, agentes do PACS e comunidade em geral, em 2 módulos e com intervalos de I semana. Os agentes do PACS deveriam avisar das reuniões do CG. Todos os conselheiros deveriam participar do Fórum de Usuários da Saúde (ATAS).

Os representantes de entidades precisavam ser mobilizados para se elaborar a relação de propostas a serem apresentadas e convidar o Prefeito para a reunião de encaminhamento das propostas (ATAS).

Sugeria-se, também, marcar nova capacitação de conselheiros, aumentar paridade para 8:4:4, pois são 3 Unidades no Complexo, e mobilizar a comunidade para se cobrar respostas dos oficios encaminhados pelo CG (ATAS). 
QUADRO 04 - DECISÕES/ENCAMINHAMENTOS DO CONSELHO GESTOR DE SAÚDE DO CRS “Dr. JOÃO ROSA PIRES” - B. AERO RANCHO/DISTRITO SUL 1997/2002

\begin{tabular}{|c|c|c|}
\hline ASPECTOS EPIDEMIOLOGICOS & SERVIÇOS DE SAÚDE & SETOR SAUUDE \\
\hline $\begin{array}{l}\text { 1.firma para limpeza periódica do CRS; } \\
2 \quad \text { levantamento de necessidades: } \\
\text { grades, vidros e sujeira dos pombos; } \\
\text { 3. CG participar da comissão de } \\
\text { trabalho para elaborar proposta para } \\
\text { dia D - anti-Dengue e mutirão anti- } \\
\text { dengue com auxilio da comunidade, } \\
\text { orientado pelos agentes do PACS e com } \\
\text { suporte da Secretaria de Obras Públicas; } \\
\text { 4. criar comissão para visitar hospitais; } \\
\text { 5. comissão para estimular reciclagem } \\
\text { do lixo do CTS, e esta, com } 4 \text { membros, } \\
\text { devendo trazer proposta para ser } \\
\text { estudada; } \\
\text { 6.o lixo deveria ser vendido e o lucro } \\
\text { destinado à associações de moradores e } \\
\text { clube de mães; }\end{array}$ & $\begin{array}{l}\text { 1 agendamento das consultas na UBS, } \\
\text { de um dia para o outro - reduz o } \\
\text { absenteismo do usuário; } \\
\text { 2. Oficio para o chefe do serviço médico } \\
\text { da SESAU, pedindo médicos; } \\
\text { 3. o coordenador do CG iria assinar a } \\
\text { falta do médico; } \\
\text { 4. anuência dos conselheiros para o } \\
\text { afastamento de agente do PACS para } \\
\text { mudança temporária para a sua micro- } \\
\text { área com o compromisso de voltar; } \\
\text { 5. 2 funcionários e } 2 \text { usuários deveriam } \\
\text { abrir a caixa da Ouvidoria antes da } \\
\text { reunião; } \\
\text { 6. orientar os usuários quanto ao } \\
\text { funcionamento do CRS e o sistema de } \\
\text { marcação de consultas; }\end{array}$ & $\begin{array}{l}\text { 1. O Fórum dos Usuários do SUS enviou } \\
\text { convite para a realização de um censo } \\
\text { para a capacitação de Conselheiros e } \\
\text { montagem de cronograma de reuniões } \\
\text { para } 1998 \text { a pedido da SESAU; } \\
\text { 2. conselheiros foram avisados do } 2^{\circ} \\
\text { módulo de oficina para conselheiros de } \\
\text { saúde no Sindicato da Construção Civil. } \\
\text { 3. distribuidos convites pelos lideres } \\
\text { comunitários dos bairros comunicando } \\
\text { eleição; } \\
\text { 4. discussão do Regimento do CG e } \\
\text { cópias para os conselheiros estudarem; } \\
\text { 5. eleita a coordenadora do conselho; } \\
\text { 6. CG deveria mandar um representante } \\
\text { para a discussão do PSF; } \\
\text { 7. indicar } 2 \text { usuárias conselheiras para }\end{array}$ \\
\hline
\end{tabular}




\begin{tabular}{|c|c|c|}
\hline $\begin{array}{l}\text { 7. elaborar folder explicativo da } \\
\text { importância do processo seletivo com o } \\
\text { apoio de entidades religiosas, agentes } \\
\text { do PACS e entidades da região; } \\
\text { 8.Oficio à SANESUL, reivindicando } \\
\text { regularização do abastecimento de água } \\
\text { num dos bairros da área; } \\
\text { 9.visitar o Centro de Múltiplas } \\
\text { Atividades - CEMA - para conhecer o } \\
\text { problema de higiene da piscina; } \\
\text { I0. enviar representante na reunião do } \\
\text { Comitê Municipal anti-Dengue; }\end{array}$ & $\begin{array}{l}\text { 7.e quanto aos pacientes com doenças } \\
\text { crônicas, orientar para procurar os } \\
\text { Programas e Prevenção por parte dos } \\
\text { agentes do PACS; } \\
\text { 8. Oficio à SESAU, pedindo bebedouro, } \\
\text { torneiras fixas, pediatra para a Unidade } \\
\text { 24 h.; } \\
\text { 9. pedido ao supervisor médico do } \\
\text { Distrito: cumprimento de horário de } \\
\text { médicos e providências para a escala } \\
\text { dos mesmos; } \\
\text { 10. a Diretora se dispôs a sentar com } \\
\text { funcionários alvo das reclamações, para } \\
\text { mudar de atitude e ver o porquê dos } \\
\text { agentes do PACS não estarem } \\
\text { desenvolvendo as atividades a contento; } \\
\text { 11. O Programa do leite e multimistura } \\
\text { para controle de crianças desnutridas, } \\
\text { deveria passar para a responsabilidade } \\
\text { dos agentes do PACS; } \\
\text { 12. só seria aceita a crítica quando }\end{array}$ & $\begin{array}{l}\text { fazer parte do Conselho Distrital para } \\
\text { melhor dinamizar as ações referentes a } \\
\text { região abrangente pelo Conselho; } \\
\text { 8. encaminhar, ainda, delegados da } \\
\text { Conferência Distrital para a } \\
\text { Conferência Municipal. } \\
\text { 9. conselheiros e a comunidade } \\
\text { deveriam lutar pelo PSF naquela } \\
\text { Unidade, inaugurada em } 1999 \text { com } \\
\text { serviços do PSF. } \\
\text { 10. aceito o encaminhamento para } \\
\text { implantar pré-consulta, } \\
\text { enfermagem, para agilizar atendimento } \\
\text { e está funcionando; } \\
\text { 11. comissão de } 4 \text { pessoas deveria } \\
\text { organizar novas eleições do CG e } \\
\text { mandar convites a organizações da } \\
\text { comunidade; } \\
\text { 12. deveria ter dois agentes PACS em } \\
\text { cada reunião do CG; } \\
\text { 13. as reuniões deveriam ser itinerantes }\end{array}$ \\
\hline
\end{tabular}




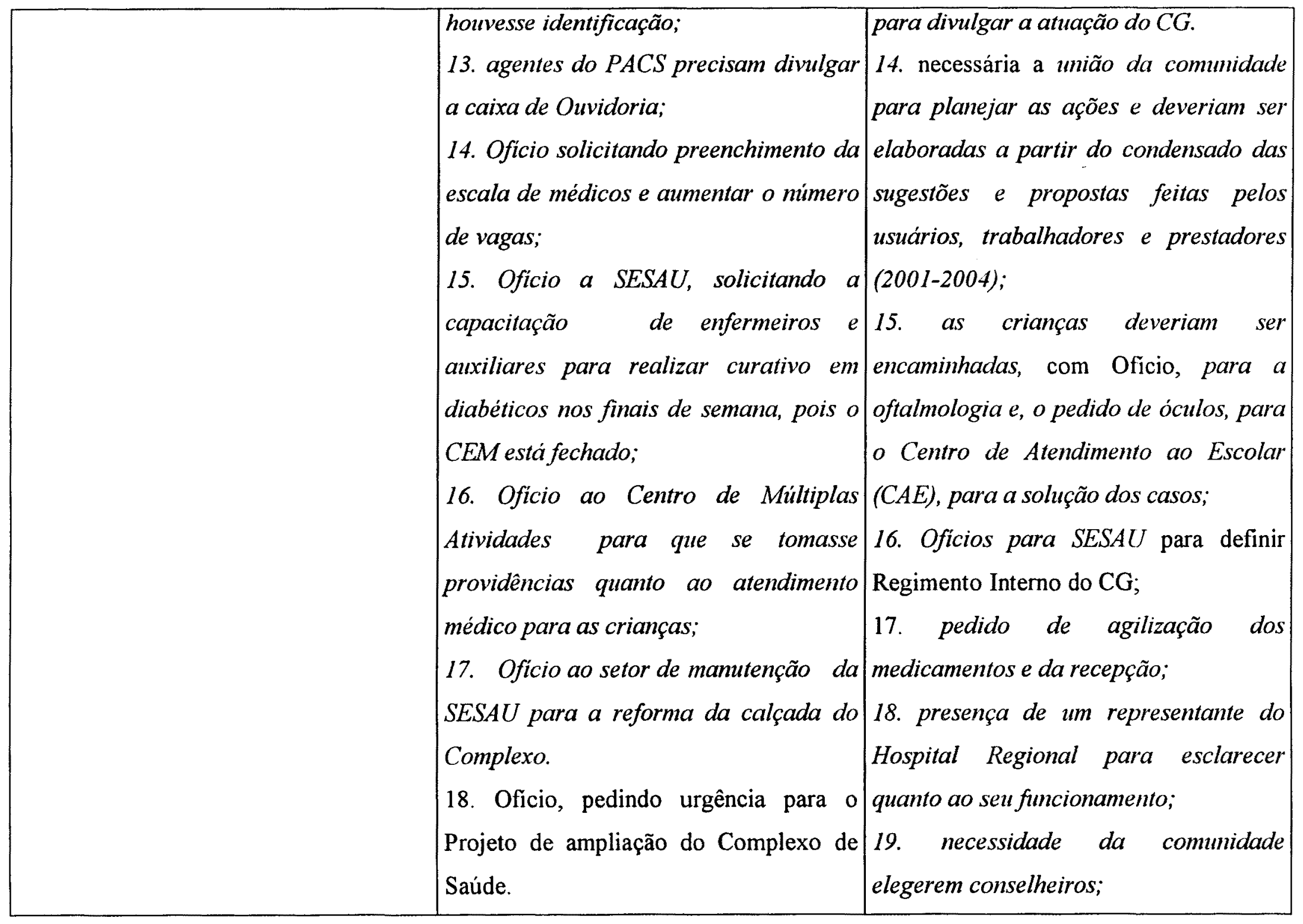




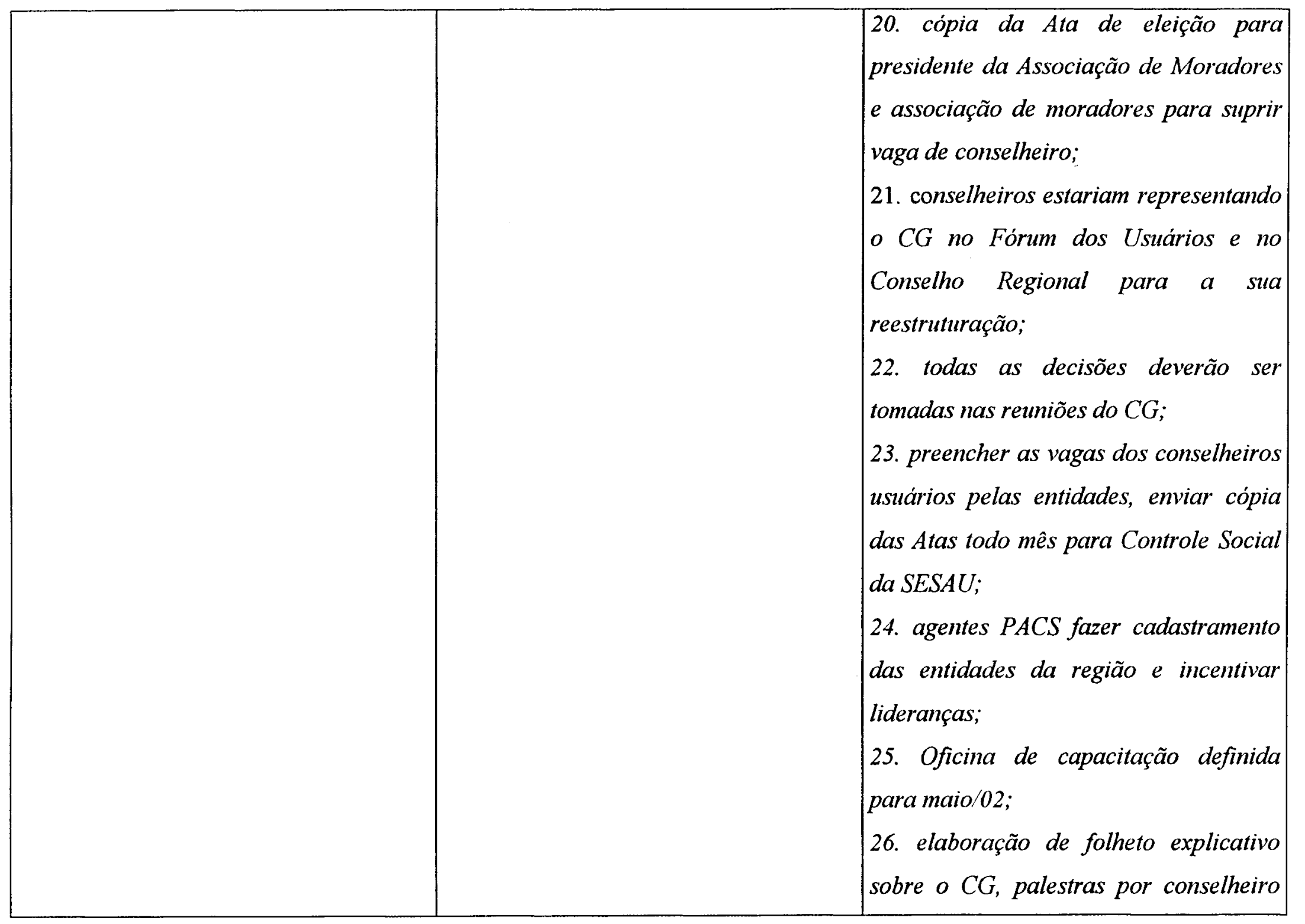

126 


\begin{tabular}{|l|l|}
\hline & $\begin{array}{l}\text { para usúrios e fazer ocorrência policial } \\
\text { quando usuários desacatarem os } \\
\text { funcionários. } \\
27 . \text { plenária de saúde do município, em } \\
2002 . \text { encaminhados } 2 \text { usuários, } 1 \\
\text { trabalhador e 1 prestador; } \\
28 . \text { um dos conselheiros usuários se } \\
\text { candidatou para a vaga de conselheiro } \\
\text { municipal. }\end{array}$ \\
\hline
\end{tabular}




\section{AVANÇOS E CONQUISTAS IDENTIFICADAS NOS REGISTROS NO PERÍODO DE ESTUDO - CRS "Dr. JOÃO PIRES ROSA" - B. AERO RANCHO/DISTRITO SUL - 1997/2002}

1. providências quanto à limpeza; Comitê da Dengue em Campo Grande/MS (2002) no qual 4 conselheiros deste Conselho fazem parte: 2 usuários, 1 trabalhador e 1 prestador;

2. Ações educativas nas escolas e gincanas envolvem os alunos, professores e agentes de saúde da área;

3. reformas da Unidade; estudo para agendamento no CEM; Ouvidoria foi estabelecida através de Caixa de Sugestões, com registro das reclamações, sugestôes e elogios;

4. o CG foi informado da lotação de médicos e dentistas para a Unidade (out./97);

5. Implantado sistema de acolhimento para dinamizar atendimento;

6. implantado PSF no Dom Antonio e Jd. Hortências mas, na Ata de 13-09-00, está registrado que não havia profissionais para assumir na área escolhida;

7. clínico no $3^{\circ}$ turno $(17-21$ h.);

8. médicos plantonistas atendem pacientes dos Programas por falta de clínico geral;

9. implantação do PAISC;

10. volta do Programa do leite com multimistura;

11. diretora do CRS pedia empenho do CG no planejamento 2000;

12. Uma Rádio FM colocou-se à disposição para maior informação sobre o atendimento do CRS e esclarecia-se a importância da Conferência Municipal de Saúde;

13. O setor de Controle Social da SESAU falava da importância do CG $e$ responsabilidade dos conselheiros;

14. Diretora do CRS se mostrava sempre presente e a frente em 2000, e em 2002 (ATAS - QUESTIONÁRIO).

\section{Posto esses fatos, posso caracterizar este CG da seguinte forma:}

CG criado há cinco anos e três meses (até dez./02); com pausas 1998 e em 2000; 
depois, novamente, para $8: 4: 4$; sua dinâmica se dá através de reuniões, agendadas através de um calendário de reuniões, de conhecimento de todos os conselheiros, dirigidas pelo(a) coordenador(a) do Conselho; não existe pauta pré-divulgada ou agendada de maneira coletiva, anteriormente. As discussões vão se dando na direção das questões levantadas pelos conselheiros ou solicitadas pela Diretora da Unidade, do Distrito e/ou SESAU; o processo de trabalho se desenvolve a partir das temáticas postas, das necessidades, seguindo, normalmente, a seqüência reivindicações - sugestões - decisão - encaminhamentos; sugestões - novas discussões - decisão - encaminhamentos; reivindicações - decisão encaminhamentos; as questões levantadas são necessidades sentidas, normalmente da população, manifestadas pelos conselheiros usuários, mas que também alcançam níveis de preocupação dos conselheiros trabalhadores e prestadores; as variadas desinformações do segmento usuários, muitas vezes, causam situações de impasse nas reuniões; As decisões - encaminhamentos não garantem a consecução das ações; a representatividade da população se dá pelas entidades de associações de bairro; dos trabalhadores, pela enfermagem e pelos agentes do PACS e, dos prestadores de serviços, pelos chefes de Unidades e da SESAU. As questões de poder são aparentes. Pede-se a participação da comunidade, espera-se novas lideranças, mas o vetor de poder nas decisões dos prestadores de serviços é superior ao dos trabalhadores e usuários, embora os encaminhamentos ganhem o aval destes segmentos, legitimando as decisões. Vê-se a tentativa de se reunir com Prefeito e Secretária(o) de Saúde na busca de maior sensibilização e, conseqüentemente, maior possibilidade de conquistas, usando-se, inclusive, a mídia para chamar a atenção das sociedades civil e política. Isto não significa que os prestadores não estejam interessados nas alternativas apresentadas pelos usuários, mas elas assumem uma roupagem mais de aconselhamento e sugestão que tomada de decisão, sendo mais palpitativo que participativo.

As demandas, objetivamente, voltam-se, de acordo com as categorias de Diagnóstico de Testa, para: 
A situação epidemiológica aponta para questões ambientais, prevenção e campanhas de vacinação. As situações de risco aparecem subliminarmente. O processo saúdedoença não é discutido na perspectiva da multicausalidade, no seu todo, mas altamente dependente da atenção primária e secundária prestadas pelas Unidades do Complexo de Saúde. Fala-se sempre em prevenção, mas a lógica das ações e serviços acontece por demanda espontânea (e reprimida) e não por um perfil epidemiológico da área.

Serviços de saúde é a categoria mais explorada nas discussões, pois falam arduamente das ações e dos serviços, Programas e da produtividade dos médicos. Percebe-se, nitidamente, a preocupação com o quê fazer e com o como fazer, na busca da eficácia do atendimento e na construção de caminhos assistenciais que tragam respostas para os desacreditados usuários. A população e, por conta disto, os conselheiros, buscam e estão esperando muito mais a eficácia do que a eficiência dos serviços. Interessa muito o fím, o produto final, parecendo importar pouco os meios, os instrumentos para a concretização da desejada eficácia - o médico sempre presente para o atendimento. Daí, a ausência de uma programação dirigida para as necessidades, mas a presença de uma rotina construída em cima da "média de tipos de atendimentos" e dos conhecimentos empíricos dos procedimentos cotidianos.

Quanto ao setor saúde, os conselheiros participam e se articulam com os demais Conselhos ligados ao Setor Saúde e entidades governamentais (escolas, creches etc.) e não governamentais (igrejas e Fórum dos idosos). Fazem sempre relação entre a infraestrutura das ações e serviços de saúde disponíveis, com a sub-produção apresentada pelas Unidades. Existe o desejo de estar sempre bem informado sobre os insumos disponíveis para garantir as demandas diárias da população. As deliberações/decisões manifestas nas reuniões e consolidadas através dos encaminhamentos de Ofícios mostram preocupações quanto a quem, hierarquicamente, se deve encaminhar, em prol de um retorno mais eficiente e mais ágil. Nem sempre se conhecem os caminhos ideais para destinar os encaminhamentos e, na tentativa de um acerto, se atrasa o processo.

Tais aspectos denotam que o CG está mais voltado, de acordo com os elementos de diagnóstico de TESTA, para a categoria Serviços de Saúde e para a modalidade Administrativo. 
Transponho as decisões/deliberações e seus encaminhamentos para o referencial do ILPES/CLAPS/OMS (1975), no intuito de identificar os componentes considerados básicos do processo decisório do Conselho

QUADRO 05 - Classificação das decisões/encaminhamentos do Conselho de Saúde do CRS "Dr. João Rosa Pires" - Campo Grande/M.S - 2002, de acordo com o referencial ILPES/CLAPS (1975)

\begin{tabular}{|l|l|c|}
\hline CATEGORIA & \multicolumn{1}{|c|}{ ELEMENTO } & $\%$ \\
\hline Nivel Político & $\begin{array}{l}\text { O CG deveria mandar um representante para discussão do PSF; } \\
\text { Conselheiros e comunidade deveriam lutar pelo PSF na UBS do } \\
\text { bairro Dom Antonio; } \\
\text { Reuniões do CG deveriam ser itinerantes. } \\
\text { Atuação na decisão da forma de agendamento padrão para as } \\
\text { Unidades de Saúde de Campo Grande/MS; } \\
\text { Oficio a SANESUL, reivindicando regularização do } \\
\text { abastecimento de água no Bairro Dom Antonio; } \\
2 \text { conselheiras usuárias para fazer parte do Conselho Distrital } \\
\text { para melhor dinamizar as ações referentes a região abrangente } \\
\text { pelo Conselho; } \\
\text { Encaminhar delegados da Conferência Distrital para Conferência } \\
\text { Municipal; } \\
\text { Discussão do Regimento do CG e distribuído cópias para } \\
\text { conselheiros estudarem; } \\
\text { Deveria ter dois agentes PACS em cada reunião do CG; } \\
\text { CG era solicitado a discutir o planejamento na área da saúde para } \\
\text { o qüinqüênio 2001-2005. }\end{array}$ \\
\hline $\begin{array}{l}\text { Prefeitura contratou firma para limpeza periódica do CRS, fruto } \\
\mathbf{3}\end{array}$ & $\mathbf{4 2 , 4}$ \\
\hline
\end{tabular}




\begin{tabular}{|l|l|}
\hline administrativo & $\begin{array}{l}\text { das reclamações dos conselheiros sobre a sujeira do prédio; } \\
\text { Diretora fala com os funcionários, alvo das reclamações, para } \\
\text { mudar de atitude e ver o porquê dos agentes do PACS não } \\
\text { estarem desenvolvendo as atividades a contento; } \\
\text { Orientar os usuários quanto ao funcionamento do CS e o sistema } \\
\text { de marcação de consultas; } \\
\text { Programa do leite e multimistura para controle de crianças } \\
\text { desnutridas deveria passar para a responsabilidade dos agentes do } \\
\text { PACS; } \\
\text { Crianças do Centro de Múltiplas Atividades deveriam ser } \\
\text { encaminhadas para oftalmologia e óculos, com Oficio, ao } \\
\text { atendimento escolar da SESAU; } \\
\text { Realizado censo para capacitação de Conselheiros; } \\
\text { Pacientes com doenças crônicas seriam orientados para procurar } \\
\text { os Programas e Prevenção por parte dos agentes do PACS; } \\
\text { Oficio à SESAU, pedindo bebedouro, torneiras fixas, pediatra } \\
\text { para a Unidade 24 h. e para supervisor médico do Distrito, } \\
\text { reivindicando o cumprimento de horário de médicos; } \\
\text { Foi encaminhado Oficio para SESAU para pedir agilização dos } \\
\text { medicamentos e maior agilidade na recepção; } \\
\text { Determinado que 2 funcionários e 2 usuários devem abrir a caixa } \\
\text { da Ouvidoria antes da reunião; } \\
\text { Lidos os bilhetes, explicados alguns deles e encaminhadas } \\
\text { providências para os possíveis; } \\
\text { encaminhar oficio a SANESUL, reivindicando regularização do } \\
\text { abastecimento de água em bairro; } \\
\text { Agentes do PACS e entidades da região: envolver-se para } \\
\text { divulgação e sensibilização da comunidade; } \\
\text { Comissão de 4 pessoas deveria organizar novas eleições do CG e } \\
\text { mandar convites e organização da comunidade para a eleição. }\end{array}$ \\
\hline & \\
\hline
\end{tabular} \mid




\begin{tabular}{|l|l|l|}
\hline Nível técnico- & $\begin{array}{l}\text { O CG deve participar da comissão de trabalho para elaborar } \\
\text { operacional }\end{array}$ & $\begin{array}{l}\text { 27,3 } \\
\text { Criar comissão para coordenar reciclagem do lixo, e esta, com 4 } \\
\text { membros, devendo trazer proposta para ser estudada; } \\
\text { O lixo deveria ser vendido e o lucro destinado para as } \\
\text { associações de moradores e clube de mães; } \\
\text { Capacitação de novos conselheiros pela SESAU; } \\
\text { Elaborar Folder explicativo da importância do processo seletivo } \\
\text { com apoio de entidades religiosas; } \\
\text { Comissão de reciclagem deveria se reunir para confecção do } \\
\text { Folder; } \\
\text { Criada a Ouvidoria, através de caixa de críticas e sugestões e } \\
\text { elogios; } \\
\text { Distribuídos convites pelos líderes comunitários dos bairros para } \\
\text { eleições do CG; } \\
\text { Montagem de cronograma de reuniões para 1998 a pedido da } \\
\text { SESAU. }\end{array}$ \\
\hline
\end{tabular}

TOTAL $=100$

É considerado como político o conteúdo dos Ofícios encaminhados.

TABELA 09 - Distribuição numérica dos tipos de decisões tomadas pelo Conselho Gestor do CRS "Dr. João Rosa Pires" - Campo Grande/M.S - 2002, de acordo com o referencial ILPES/CLAPS (1975)

\begin{tabular}{|c|c|c|}
\hline CATEGORIA & NÚMERO & $\%$ \\
\hline Nível Político & 10 & 30,3 \\
\hline Nivel Técnico-Administrativo & 14 & 42,4 \\
\hline Nível técnico-Operacional & 9 & 27,3 \\
\hline TOTAL & 33 & 100 \\
\hline
\end{tabular}

Fonte: Atas das reuniões 
6.3 CONSELHO GESTOR DO CRS "Dr. MARCÍLIO OLIVEIRA LIMA"
B. MORENINHA III - DISTRITO LESTE - 
O CG da Unidade de Saúde "Dr. Marcílio de Oliveira Lima", conhecido como Centro de Saúde $24 \mathrm{~h}$. do bairro Moreninha III, iniciou suas atividades em 01/10/96, numa reunião convocada pelo Diretor do CRS com a comunidade dos bairros das Moreninhas (I, II, III, IV). O objetivo desta $1^{\mathrm{a}}$ reunião foi esclarecer a comunidade sobre as finalidades do CG e responsabilidades dos conselheiros (ATA $\mathrm{N}^{\circ} 1$ ). Nessa reunião, a coordenadora do CG do CRS do bairro Universitária (mesmo Distrito) fez uma palestra sobre suas experiências e dificuldades com o CG.

Nessa primeira reunião, encontravam-se as seguintes pessoas: Diretor do CRS, coordenadora do CG do bairro Universitária, Diretora do Distrito Leste, assistente social do bairro Universitária, representantes da Pastoral da Criança, servidores da Fundação Nacional de Saúde, presidente do clube de mães e funcionários do CRS Moreninha III. Estes presentes acordaram que, em 08/10/96, escolheriam os conselheiros deste $\mathrm{CG}$.

Para a data combinada, foi convocada a $2^{\mathrm{a}}$ reunião pelo Diretor da Unidade para a formação do $\mathrm{CG}$, oficialmente. Houve um rápido esclarecimento do objetivo e função do CG. A votação foi aberta e 10 usuários, representando algumas associações de moradores, se propuseram a ser eleitos como conselheiros. Duas pessoas não tiveram nenhum voto. Dos oito, os mais votados ficaram como titulares e cada titular escolheu seu suplente. A paridade do CG ficou 4:2:2. Decidiram que os conselheiros elegeriam a coordenadora e que teriam uma reunião por semana.

Com 7 dias, fez-se a $3^{\mathrm{a}}$ reunião, convocada pela coordenadora do CG, tendo como primeiros assuntos da pauta: estudo do Regimento Interno do $C G$, urnas para ouvidoria - uma para criticas e outra para sugestões, sugestões dos conselheiros e suplentes presentes, endereços e telefones de cada conselheiro e direito do funcionário participante do Conselho ser liberado para as reuniões. A urna seria aberta de $15 \mathrm{em} 15$ dias (ATA $\mathrm{N}^{\circ} 3$ ).

Na ATA No 29 (p. 23, 08/10/96), assim está registrado, sobre o histórico deste CG: 
Desde a formação desta diretoria já se passaram um ano e cinco meses e nós continuamos a nos reunir mensalmente sem nenhuma falta. Apenas por motivos de trabalho e horários foi necessário a troca de alguns conselheiros. (...) Devido a algumas irregularidades relatadas nas Atas anteriores, tivemos a necessidade de contar todo o início da formação deste Conselho para o mesmo se tornar legalizado. E depois de tantas lutas e sacrificios, continuaremos nos reunindo como um Conselho Gestor dinâmico e legalizado corretamente conforme nos foi pedido para o registro do Conselho que fica organizado (...).

O Registro do CG aconteceu em 23/3/98.

\subsection{A. ASPECTOS DO FUNCIONAMENTO DO CONSELHO GESTOR DO CRS “Dr. MARCÍLIO OLIVEIRA LIMA” - B. MORENINHA III - DISTRITO LESTE 1996/2002}

\subsection{A.1 PERIODICIDADE DAS REUNIÕES}

Desde a data do início das atividades (01/10/96) e durante este ano, aconteceram oito reuniões, com intervalos variando de 7 a 15 dias. Foi um início intenso, com uma média de 13 membros presentes. Em 1997, os registros apontam para 15 reuniões, com periodicidade entre 7 a 63 dias, com média de 11 membros por reunião. Em 1998, 14 reuniões, intervalos de 4 a 65 dias e média de 21 membros presentes. Em 1999, 12 reuniões, periodicidade entre 4 a 44 dias e média de 12 presentes. No ano de 2000, aconteceram 14 reuniões, periodicidade entre 4-64 dias e média de 21 membros presentes. Em 2001, aconteceram 10 reuniões e uma pausa de 90 dias. $\mathrm{O}$ ano de 2002, vivenciou somente 6 reuniões e uma pausa de 75 dias.

Este CG evidencia uma dinâmica estável - periodicidade mais sistemática e membros presentes numa média mais constante. Os anos de 1998, 2000, 2001 e 2002 mostram maior participação nas reuniões.

Ocorreram algumas mudanças na composição, por substituição de conselheiros devido a motivos variados, tais como: desinteresse, falta de tempo, envolvimento 
com outras atividades, desinformação do papel do $\mathrm{CG}$ e reduzida credibilidade no papel do CG dentre outros. A falta de conselheiros, principalmente usuários, tem sido um problema constante, mostrando a necessidade de seguidas substituições. A participação de agentes do PACS faz-se por um número maior que nos outros CG.

TABELA 10 - Periodicidade das reuniões do Conselho Gestor de Saúde do CRS "Dr. Marcílio Oliveira Lima" - Moreninha III - Distrito Leste - Campo Grande $1996 / 2002$

\begin{tabular}{|c|c|c|c|c|c|c|}
\hline ANO & $\begin{array}{c}\mathbf{N}^{\circ} \\
\text { REUNIÕE } \\
\mathrm{S}\end{array}$ & $\begin{array}{c}\text { Média de no }^{\circ} \\
\text { presentes }\end{array}$ & $\begin{array}{c}\text { PERIODICIDAD } \\
\text { E }\end{array}$ & PARALIZAÇŌES & $\begin{array}{l}\text { ELEIÇÓES } \\
\text { PARIDADE }\end{array}$ & COORDENADOR \\
\hline 1996 & 8 & 13 & $7-15$ dias & & $08 / 10 \quad 4: 2: 2$ & Usuário \\
\hline 1997 & 15 & 11 & $7-63$ dias & & & \\
\hline 1998 & 14 & 21 & $4-65$ dias & & $\begin{array}{l}12 / 3 \text { - registro } \\
\text { oficial: } 4: 2: 4 \\
7 / 11 \quad 3: 4: 4\end{array}$ & Usuário \\
\hline 1999 & 12 & 12 & 4-44 dias & & & \\
\hline 2000 & 14 & 21 & $4-64$ & & $29 / 11 \quad 4: 2: 2$ & Usuário \\
\hline 2001 & 10 & 21 & $14-90$ dias & $\begin{array}{l}17-3 \text { à } 17-6= \\
90 \text { dias }\end{array}$ & $\begin{array}{l}\text { 18/10 - eleição } \\
\text { complementar } \\
\text { para } 6: 3: 3\end{array}$ & \\
\hline 2002 & $\begin{array}{l}6 \text { (até } \\
\text { agosto) }\end{array}$ & 20.2 & $28-75$ & $\begin{array}{l}20-12-01 \text { à } 07- \\
03-02=75 \text { dias }\end{array}$ & & \\
\hline
\end{tabular}

FONTE: Atas das reunioes

\subsection{A.2 COMPOSIÇÃO DO CONSELHO GESTOR}

Em 08/10/96, foi realizada a $1^{\circ}$ eleição, com paridade $4: 2: 2$; a $2^{a}$ eleição, em 07/11/98, com a composição $3: 4: 4$, a $3^{\text {a }}$ eleição, em 29/11/00, com paridade 4:2:2. Em 18/10/01, fez-se uma eleição complementar para alterar a composição para 6:3:3.

\subsection{A.3 - REPRESENTATIVIDADE - ATORES}

A representação é realizada por: conselheiros usuários do SUS - representando as entidades: associação de mulheres da Moreninha I, II e III, associação de moradores 
dos bairros da área de abrangência, líderes comunitários, usuários dos serviços. Dos trabalhadores de saúde - conselheiros trabalhadores, funcionários da Fundação Nacional de Saúde, agentes do PACS (sem direito a voto) e prestadores de serviço gerentes das Unidades do Complexo de Saúde, Chefe do Distrito. Esta representação não garantia a representatividade. Quando convidados, faziam-se presentes Secretário(a) de Saúde, representantes do Serviço de Controle Social da SESAU, e outros visitantes/convidados: conselheiros de outros $\mathrm{CG}$, enfermeiros do $\mathrm{HU}$, coordenador CEMA, primeira dama do município, conselheiro estadual de saúde e regional, governador do estado do Mato Grosso do Sul, TV Morena, engenheiro da Secretaria de Obras do município, assistente social e engenheiro da SANESUL e Movimento Força Comunitária, dentre outros não relatados.

Os motivos da participação dos conselheiros foram representar o trabalhador de saúde, ajudar os usuários, necessidade de melhoria (questionário). Alguns conselheiros já participaram de Conselhos de Associação de Pais e Mestres, outro, de CG; dois, nunca participaram de Conselhos. Todos conheciam o Regimento. Afirmavam que, quanto às decisões, todos aprovam a melhor sugestão.

O Fórum dos Usuários do SUS, do município, aparece como elemento mediador e esclarecedor de dúvidas e sempre disposto a acompanhar e dirimir dúvidas dos conselheiros. Foi criado também o Fórum de Usuários desta Unidade.

\subsection{B - DINÂMICA DO FUNCIONAMENTO DO CONSELHO}

\section{GESTOR: a prática de atuação do conselho}

A finalidade, objetivo, função, responsabilidade e a necessidade da participação sistemática dos conselheiros usuários e a divulgação do papel do CG são preocupações constantes nas reuniões e foram questões apresentadas na $1^{\mathrm{a}}$ reunião, convocada pelo Diretor do CRS da Moreninha III e com a comunidade dos bairros da região das Moreninhas. 
As reuniões eram feitas, inicialmente, no Centro Comunitário do bairro Moreninha III. Depois, passaram a ser itinerantes: diocese, biblioteca do bairro, mas a maioria aconteceu no CRS.

A partir da $3^{\mathrm{a}}$ reunião, a rotina de trabalhos continuou, de acordo com as Atas, com as demandas variadas, num cenário, também, de muito palpite e informações.

O momento de reuniões tornavam-se cenário para muitas informações, dentre elas, policiamento do $C S$, convite do $1^{\circ}$ Encontro de $C G$, explicação sobre o trabalho do Fórum dos Usuários do SUS, Metas para 1997, Programação 1999 e informações sobre os $A A$ (ATAS).

O secretário da associação de moradores queria saber o que era CG. A pastoral mandou convites para esclarecimentos de remédios caseiros feitos pela pastoral. As Leis e principios do SUS, necessidade de participação popular e diferença entre Urgências e Emergências são assuntos sempre presentes nos registros das Atas.

Foi avisado, em 21/12/99, da Conferência Distrital Leste a ser realizada em 1718/02/00, devendo servir de orientação e preparo para a XI Conferência Nacional de Saúde em Brasilia (ATA). Haveria Seminário para capacitação de delegados para a Conferência Municipal de Saúde.

\section{QUEIXAS DO CONSELHO GESTOR DE SAÚDE DO CRS “Dr. MARCÍLIO OLIVEIRA LIMA" - B. MORENINHA III - DISTRITO LESTE - 1996/2002}

\section{ASPECTOS EPIDEMIOLÓGICOS}

O CG alertava para o perigo de leishmaniose, colocava problemas como limpeza e higiene do CRS - banheiros, principalmente. Água servida escorrendo pela rua, fossas e bocas de lobo cheias e falta da atuação da Vigilância Sanitária nos bairros quanto a questões de saneamento básico também eram alvos de reclamações (ATAS). 


\section{SERVIÇOS DE SAÚDE}

A relação dos funcionários fantasmas do CRS foi uma das buscas. A marcação de consultas - agendamento - na UBS, também causou muita polêmica e vemos o CG discutindo em várias reuniões caminhos para a sua solução. Quanto aos recursos humanos - transferência da farmacêutica, quadro de médicos, escala de plantões - são temas sempre presentes. Uma escola pública enviou um Ofício, reclamando não haver profissional para atender a escola. Posteriormente, a nova diretora afirmava da dificuldade para contratação (ATAS).

Quanto aos serviços da Unidade, o Diretor afirmava a falta de médicos, de Programas, de ambulância e de remédios. Houve denúncia do CG sobre atendimento médico e com morte de usuário, falta de funcionários e médicos, estes, não substituidos nas férias. Ainda, equipe de preventivo de Câncer desarticulada, agressões aos profissionais de saúde, a maioria das consultas não serem de urgências, falta de profissional dentista em escola, volta da fila e retirada da senha para agendamento, desencontros na marcação de consultas, agressões físicas e morais a médicos e funcionários pelos usuários, ameaça de funcionário ao Diretor do $C R S$ - queixa no $7^{\circ} \mathrm{DP}$, desinformação para marcação de consultas no CEM. Quanto à infra-estrutura, faltavam banheiros e bebedouro e, na mídia, reclamações pelos usuórios sobre as senhas de consultas. Após críticas do serviço, alguns trabalhadores de saúde diziam que as pessoas falam porque não sabem o que acontece no CRS (ATAS).

\section{SETOR SAÚDE}

As queixas se relacionam à falta de participação popular nas atividades do $C G, e$ conselheiros faltosos.

\section{SUGESTÕES DO CONSELHO GESTOR DE SAÚdE DO CRS "Dr. MARCÍlIO OLIVEIRA LIMA" - B. MORENINHA III - DISTRITO LESTE - 1996/2002}

\section{ASPECTOS EPIDEMIOLÓGICOS}


Que a Secretaria de Obras desse condições para as pessoas construírem suas fossas. Pedia-se maior interação do $C G$ e comunidade para ações e fiscalização de saneamento básico: coleta de lixo e rede de esgoto. O CG propunha forma sumidoura nas casas, desentupimento das bocas-de-lobo, fiscalização em bares e lanchonetes, propondo fazer ações educativas através de vídeo - equipamento este pertencente ao Distrito. Ainda, visitas domiciliares em borracharias, investigar dengue hemorrágica, orientação sobre AIDS, divulgar perigos da leishmaniose nas escolas, igrejas com vídeos educativos e vistoriar carteira de vacinação de cães e gatos. É indicado como principal solução para Verminose, diarréia, piolhos - nos escolares, água tratada nos bairros carentes da área de abrangência deste CRS, pois são decorrentes de saneamento deficitário e contato com animais domésticos (ATAS).

\section{SERVIÇOS DE SAÚDE}

O novo diretor vinha de um outro CRS e, logo na primeira reunião que ele participava, pedia apoio - caminhar junto com a comunidade, e apresentava seu método de trabalho: parcerias com escolas, igrejas, postos policiais, creches e associação de moradores. Quanto aos serviços - segurança da Unidade, usos e liberação da Ambulância, avisos para vacinação, prevenção de câncer, dia da mama, comentários sobre PACS, importância da urna, orientações sobre o funcionamento dos Programas, usos indiscriminados dos serviços de urgência/emergência, importância da multimistura, bem como, ainda, direitos do paciente, também eram sempre discutidos. Pedia-se ajuda ao novo diretor do CRS para melhorar o atendimento. No intuito de facilitar o uso dos serviços da Unidade, sugeriram, também, barras para bicicletas e compra de microfone para facilitar a chamada dos pacientes (ATAS).

A construção da maternidade e centro de pequenas cirurgias e mudança do nome de Unidade Mista para Hospital da Mulher foram reivindicações dos conselheiros. Os serviços de obstetrícia e ambulatório deveriam ser referência para esta especialidade. Houve comentários negativos do Diretor do $\mathrm{CRS}$, mas funcionários e conselheiros reivindicaram sua permanecia e o pedido foi aceito. 
A SESAU fez divulgação do SISVAN, para que os conselheiros ajudassem orientar as pessoas sobre este Programa. Sugeria-se mutirão de limpeza feita por usuários, conselheiros e funcionários. Cartazes foram colocados para incentivar a limpeza.

A Urna no CRS deveria ser aberta a cada 15 dias. Sugeriram não marcar consultas todo o dia para muito tempo à frente, melhorar atendimento da recepção, farmácia e laboratório, melhor local para a espera, mudança do horário da inalação, mais atenção na pré-consulta, mais agilidade no atendimento, farmácia mais ampla e com mais remédios, prioridade nas consultas para criança com menos de 5 anos e fechadura na sala do computador. Quanto aos recursos humanos, psicólogo para a Unidade, pois fica longe o Posto do INSS, mais funcionários de plantão, mais médicos e torneira para sala de médico. Ainda, Ofício para angariar materiais para a construção, ações educativas na escola, pela FNS, e cartazes esclarecedores sobre o CEM e das reuniões do CG (ATAS - QUESTIONÁRIO).

\section{SETOR SAÚDE}

As reuniões, inicialmente, eram semanais. Endereços e telefone de cada conselheiro deveriam ficar registrados na Unidade, seguir o Regimento Interno, atentar para as faltas dos conselheiros, cursos de relações humanas, CG elaborar Projeto contemplando as necessidades da comunidade, esclarecer as dificuldades e forma de atendimento do CRS. Deveriam, ainda, fazer parceria com a pastoral (ATAS).

Os conselheiros deveriam se envolver em documentos de captação de recursos do municipio, participar de Encontros para elaborar documentos do orçamento/99 $e$ Planejamento, além de fazer projeto para pegar verba REFORSUS e VIGISUS (ATAS).

A Secretária de Saúde dirigia-se ao CG para recomendar que o CG atentasse para não faltar remédio, cuidar da fila e dar sugestões e que as questões de recursos humanos e administrativos eram de sua confiança. 
Foi solicitada parceria com HU, mas o Secretário de Saúde pediu prazo. O Secretário de Saúde avisava sobre a falta de funcionários. 
QUADRO 06 - ENCAMINHAMENTOS DO CONSELHO GESTOR DE SAÚDE DO CRS “Dr. MARCÍLIO OLIVEIRA LIMA" - B. MORENINHA III - DISTRITO LESTE - 1996/2002

\begin{tabular}{|c|c|c|}
\hline ASPECTOS EPIDEMIOLÓGICOS & SERVIÇOS DE SAÚDE & SETOR SAÚDE \\
\hline $\begin{array}{l}\text { 1.Conselheiros participaram de curso sol } \\
\text { combate e prevenção da dengue; } \\
\text { 2.Ofício para o presidente da vila pd } \\
\text { estender a limpeza do bairro até o CRS; } \\
\text { 3.esclarecimentos para vacina anti-rábica, } \\
\text { 4. Comissão foi falar com o Prefeito sol } \\
\text { águas servidas: conselheiros, presidente } \\
\text { bairro e Diretor do CRS para contatar co } \\
\text { engenheiro responsável ou Secretario } \\
\text { Obras. }\end{array}$ & $\begin{array}{l}\text { 1.Eleição dos coordenadores pe } \\
\text { conselheiros; } \\
\text { 2. estudo do Regimento Interno do CG; } \\
\text { 3.construção de uma urna para colher críti } \\
\text { e sugestões; } \\
\text { 4.encaminhamento de Oficios: solicitando } \\
\text { profissional de saúde para atender uma } \\
\text { escola pública e atenção quanto ao quadro } \\
\text { funcionários; } \\
\text { 5. angariar torneira e fechadura. } \\
\text { 6. Pediram latas para destinar agulhas usad } \\
\text { 7. Algumas necessidades que a SESA } \\
\text { demorou resolver: troca de porta velha } \\
\text { Unidade: solução: rifa. }\end{array}$ & $\begin{array}{l}\text { 1.Troca de coordenador para conselhe } \\
\text { usuário; } \\
\text { 2. reuniões semanais nas casas p } \\
\text { esclarecimento, para prevenção, devido à pou } \\
\text { participação de usuários e dos conselheiros; } \\
\text { 3. esclarecimento sobre emergência e } \\
\text { atendimento de plantão; } \\
\text { 4. Oficio para comandante do batalh } \\
\text { solicitando um policial para CRS; } \\
\text { 5. as Queixas deveriam ser encaminhadas } \\
\text { Diretor da Unidade; } \\
\text { 6.equipe para elaborar video para SANESU } \\
\text { técnicos da Prefeitura; } \\
\text { 7.A programação de 1999 se propunha } \\
\text { abordar questões como recursos human } \\
\text { programas de saúde, serviços de complexida }\end{array}$ \\
\hline
\end{tabular}




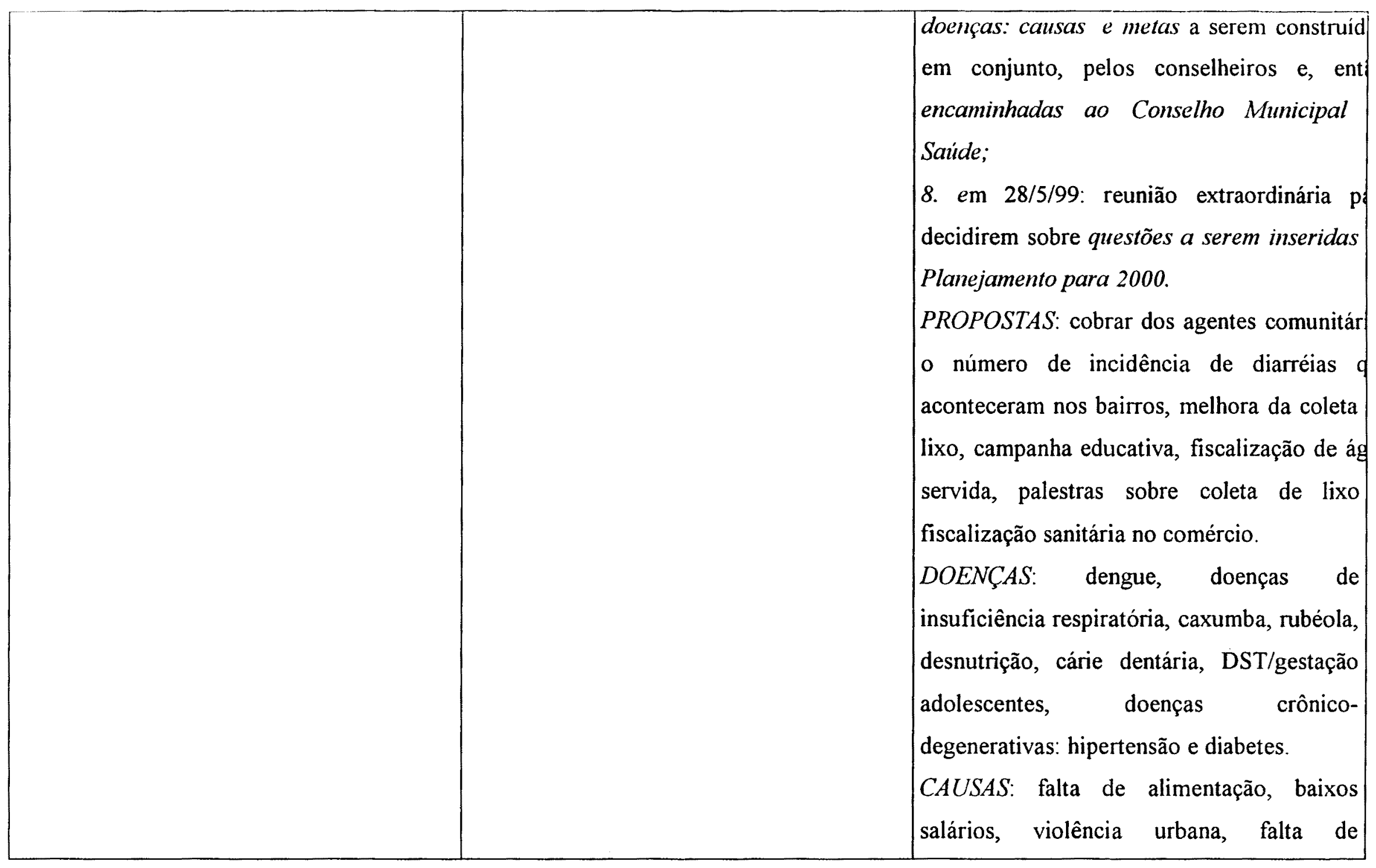




\begin{tabular}{|l|l|l|}
\hline & $\begin{array}{l}\text { informação e prevenção e desajuste social. } \\
N E C E S S I D A D E S \text { melhoria de aparelhos } \\
\text { necessários para as consultas e os } \\
\text { procedimentos, orientações, importância do } \\
\text { cartão de vacina, implantação de Programas } \\
\text { entratação de profissionais. } \\
\text { METAS: Orientações às borracharias e } \\
\text { outros locais contaminados, implantar a } \\
\text { vigilância epidemiológica, adquirir material } \\
\text { educativo, integração com o PACS e } \\
\text { pastoral da criança, Programa de } \\
\text { alternativas alimentares, planejamento } \\
\text { familiar, orientar pessoal para atendimento, } \\
\text { continuação da prevenção, diminuir o } \\
\text { consumo de bebidas alcoólicas e realização } \\
\text { de palestras. }\end{array}$ \\
\hline
\end{tabular}




\section{AVANÇOS E CONQUISTAS IDENTIFICADAS NOS REGISTROS NO PERÍODO DE ESTUDO - CRS "Dr. MARCÍLIO OLIVEIRA LIMA" - B. MORENINHA III - DISTRITO LESTE - 1996/2002}

1. Realizada transferência de funcionários fofoqueiros não-lotados na Unidade para outra Unidade de Saúde, feita a transferência em 6 meses;

2. têm-se médicos de plantão nos 3 turnos;

3. chegada de pediatra, dentista, oftalmologista, auxiliares de enfermagem e auxiliares sociais. Entretanto, hoje (2002), existem dificuldades quanto aos pediatras, sendo isto, inclusive, causa de denúncia do Setor Saúde no Conselho Tutelar;

4. bebedouro (demorou para ser atendido) e ambulância de plantão (a ambulância era emprestada de outro CRS, mas passaria por reformas e ficaria em definitivo nesse CRS;

5. o retorno da senha aconteceu um mês depois da reclamação na midia: uma pesquisa revelou usuários descontentes com a volta da fila e a retirada da Senha para agendamento na UBS. A questão foi parar na mídia. Houve discussão no Fórum de Usuários. O Prefeito pediu que a comunidade se posicionasse se queria a senha e não deixar que grupos radicalistas decidissem tirar a senha. Foi feita uma votação na fila com o seguinte resultado: 404 para a senha e 16 a para fila;

6. agendamento diário com senha, na UBS: diminuiu a fila para marcar as consultas. Percebe-se, nos relatos, melhor funcionamento da Unidade e a redução das reclamações (ATA, 29/01/98);

7. troca de 2 gabinetes dentários, agora, novos;

8. em julho de 1998, estavam estabelecidos os Programas: do diabetes, da criança, da mulher, do adolescente, do Hipertenso, da Hansen, da Tuberculose e da coleta escarro, reunião de hipertensos e... melhor atendimento no $\mathrm{CS}$;

9. reforma do CRS se fez em 2 meses - construção da maternidade e centro cirúrgico para pequenas cirurgias. $O$ Diretor do $C R S$ afirmava que se houvesse maior intervenção do Conselho, poderíamos ter melhores resultados; 
10. agendamento com Secretário de Saúde para se levar as necessidades e sugestões dos usuários. A identificação de necessidades foi feita de casa em casa e com treinamento para os entrevistadores;

11. Enviado documento para o Fórum de Usuários para ser encaminhado ao Conselho Municipal de Saúde (CMS), requerendo ambulância, e o Prefeito disse ser só para março/98 - uma demora de 5 meses;

12. capacitação de conselheiros (ATAS - QUESTIONÁRIO).

\section{Este CG têm as seguintes caracteristicas:}

CG criado há seis anos (até dez./02); com duas pausas: 90 dias, em 2001 e 75 dias em 2002; com dinâmica relativamente estável durante todos os anos; teve composição alterada várias vezes: de $4: 2: 2$, em out./96 para 3:4:4, em nov./98, para $4: 2: 2$, em nov./00 e para 6:3:3 em out./01; sua dinâmica se dá através de reuniões dirigidas pelo coordenador, com participação ativa da gerente do Complexo de saúde e, hoje, da gerente do CRS, secretariadas sistematicamente e com os devidos registros em Atas. Normalmente, a pauta é apresentada no início da reunião e as discussões vão se dando na direção das questões colocadas preliminarmente e, vez ou outra, tem-se um item de acréscimo; o processo de trabalho se desenvolve a partir das temáticas postas, seguindo-se em discussões e debates, nem sempre culminando em decisões. É mais comum terminar em sugestões; as questões levantadas são necessidades sentidas da população e dos conselheiros, manifestadas pelos conselheiros; as decisões - encaminhamentos não garantem a realização das ações; a representatividade da população se dá pelas entidades de associações de bairro, associação de mulheres e líderes comunitários. Dos trabalhadores, pela enfermagem, funcionários da FUNASA e, sem direito a voto, dos agentes do PACS. Os prestadores de serviços são representados pelos gerentes da UBS e do CRS. Gerentes do Distrito e outros convidados da SESAU estão presentes esporadicamente; As questões de poder aparecem de maneira contundente quando os médicos querem tirar - Diretor da Unidade, mas ele acaba ficando pelo apoio dos funcionários e dos usuários. Funcionários fantasmas são identificados e desligados na Unidade e funcionários incompetentes e descompromissados são vigiados e pedem a sua transferência; os usuários vão para a imprensa reclamar do agendamento $e$ 
conseguem a volta da senha. Este CG mostrou ter uma liderança mais politizada que os outros.

As demandas, objetivamente, voltam-se, de acordo com as categorias de Diagnóstico de TESTA, para:

A situação epidemiológica aponta para questões ambientais, prevenção e saneamento básico, de maneira enfática, ao se pedir ajuda para os moradores na construção de fossas. As questões de saúde-doença são muito dependentes da prevenção e da assistência médica. A demanda espontânea sempre está em defasagem causando insatisfação quanto à disponibilidade e à qualidade dos serviços prestados. A dengue é um risco intensamente combatido, por pedidos intensos da SESAU. Os agentes de saúde enfrentavam dificuldades com imóveis fechados e com moradores que recusavam atender às vistorias. Hoje, o Ministério Público tem agido prontamente nestas situações. Situações de risco para leishmaniose impõem preocupações quanto a animais domésticos.

Serviços de saúde é categoria bastante presente nas discussões. Percebe-se intensa preocupação com os serviços oferecidos. Buscando a eficácia, procuram e fazem parcerias. Valorizam a prevenção através dos Programas, atuação dos agentes do PACS e vacinações. Exigem a ambulância disponível na Unidade e discutem as agressões de usuários para funcionários e mal atendimento dos usuários.

Quanto ao setor saúde, os conselheiros valorizam ações interinstitucionais, as normas colocadas pelas Leis do SUS e o Regimento do CG. Buscam as necessidades e procuram melhor integração com os outros serviços do sistema de saúde pública. Insistem na melhoria da informação da população através das reuniões nas residências e educação em saúde nas escolas numa ação conjunta com a FUNASA.

Tais aspectos denotam que o CG está mais voltado, de acordo com os elementos de diagnóstico de TESTA, para a organização e administração dos serviços. A modalidade Administrativo tem predominância. 
Transpondo tais questões para a análise dos componentes do processo decisório proposto para este estudo, encontramos o seguinte cenário:

QUADRO 07 - Classificação das decisões/deliberações do Conselho Gestor do CRS "Dr. Marcílio Oliveira Lima" - B. Moreninha III - Distrito Leste - 1996/2002 segundo ILPES/CLAPS1975)

\begin{tabular}{|c|c|c|}
\hline CATEGORIA & ELEMENTO & $\%$ \\
\hline Nível Político & $\begin{array}{l}\text { CG discute sobre funcionários fantasmas e encaminha pedidos } \\
\text { para Prefeito para substituição; } \\
\text { Solução para agendamento, a época: da modalidade de } \\
\text { reconquistaram, após pesquisa a pedido do Prefeito } \\
\text { reclamações na mídia, o retorno da senha, facilitando o proces } \\
\text { de agendamento; } \\
\text { Troca de coordenador para um conselheiro usuário e reintegra } \\
\text { conselheira, com justificativa; } \\
\text { Encaminhado Oficio ao comandante do batalhão para arrun } \\
\text { um policial para o CRS; } \\
\text { Reunião extraordinária para questões a serem inseridas } \\
\text { Planejamento para } 2000 \text {; } \\
\text { Comissão foi falar com o Prefeito sobre a água escorrendo na } \\
\text { Rua; } \\
\text { Em } 28 / 5 / 99 \text {, reunião extraordinária para se definir questões } \\
\text { serem inseridas no Planejamento para } 2000 \text {. }\end{array}$ & 43,7 \\
\hline $\begin{array}{l}\text { Nível técnico- } \\
\text { administrativo }\end{array}$ & $\begin{array}{l}\text { Oficio para angariar torneira e fechadura nos depósitos de } \\
\text { construção; } \\
\text { Pediram latas para destinar agulhas usadas; } \\
\text { As Queixas deveriam ser encaminhadas ao Diretor da Unidade } \\
\text { Esclarecimentos para vacina anti-rábica; }\end{array}$ & 25 \\
\hline
\end{tabular}




\begin{tabular}{|c|c|}
\hline $\begin{array}{l}\text { Nível técnico- } \\
\text { operacional }\end{array}$ & $\begin{array}{l}\text { Conselheiros participam de curso sobre combate e prevenção } \\
\text { da } \\
\text { dengue; } \\
\text { Comissão: conselheiros, presidente de bairro e Diretor do CRS } \\
\text { para contactar com engenheiro responsável ou Secretário de } \\
\text { Obras; } \\
\text { Reuniões semanais nas casas devido à pouca participação de } \\
\text { usuários e dos conselheiros, para esclarecimentos quanto aos } \\
\text { serviços, prevenção e esclarecimento sobre emergência e } \\
\text { atendimento de plantão; } \\
\text { Oficio ao presidente da vila para estender a limpeza do bairro } \\
\text { até CS; } \\
\text { Montar equipe para elaborar video para SANESUL e técnicos } \\
\text { prefeitura. }\end{array}$ \\
\hline
\end{tabular}

TOTAL $=100$

TABELA 11 - Distribuição numérica dos tipos de decisões tomadas pelo Conselho Gestor de Saúde do CRS "Dr. Marcílio Oliveira Lima" - B. Moreninha III Distrito Leste - 1996/2002

\begin{tabular}{|c|c|c|}
\hline CATEGORIA & NÚMERO & $\%$ \\
\hline Nível Político & 7 & 43,7 \\
\hline Nivel Técnico-Administrativo & 4 & 25 \\
\hline Nível técnico-Operacional & 5 & 31,3 \\
\hline TOTAL & 16 & 100 \\
\hline
\end{tabular}

Fonte: Atas das reuniões 
6.4 CONSELHO GESTOR DE SAÚDE DO CRS "Dr. JOSÉ GERALDO ABUHASSAN" - VILA ALMEIDA/DISTRITO OESTE - 1994/2002 
O CG do Centro Regional de Saúde "Dr. Gilberto Abuhassan", conhecido como Centro de Saúde $24 \mathrm{~h}$. do bairro Vila Almeida, iniciou suas atividades em 25/02/1994. Nesta primeira reunião se encontravam as seguintes pessoas: Secretário Municipal de Saúde, Diretor Executivo' ${ }^{1}$ da SESAU, dois representantes dos trabalhadores de saúde, dois representantes da administração da saúde pública municipal, quatro representantes da população usuária e cinco líderes dos bairros vizinhos do CRS. O objetivo desta reunião era discutirem sobre o rumo da saúde em nossa região (ATA № 1).

Dizia o Diretor Executivo da SESAU que a solução de todos os problemas não seria a curto prazo, mas sim, a médio e longo prazos. Afirmava, ainda, que o problema da saúde no Brasil é crônico, que os recursos do governo federal são escassos; que o que está escrito na Constituição Federal não está sendo cumprido - Saúde, direito do cidadão e dever do Estado. Continuava a sua fala afirmando que a saude foi municipalizada e, na reforma constitucional, não fora dito o montante de recursos que seriam destinados à saúde e que até aquele momento não se sabia qual era. Os Postos de Saúde deveriam atender, prioritariamente, a população carente. Os Hospitais Santa Casa e Universitário não podiam atender somente pessoas de Campo Grande/MS, mas os de outros lugares também. Afirmava, ainda, que o Prefeito estava empenhado em fazer o melhor pela saúde e esperava contar com a ajuda de todos e, para tanto, seria fundado nesta data o Conselho Gestor de Saúde da região (ATA No 1).

Com 18 dias, fez-se a $2^{\mathrm{a}}$ reunião com o Diretor Executivo e lideranças comunitárias vizinhas ao CRS para darem continuidade à discussão sobre o atendimento médico, odontológico e administrativo da Unidade.

As reivindicações foram feitas e o Dr. ... foi explicando o que tem condições de ser feito a longo e médio prazo. As solicitaçz̃es foram: ampliação do Centro de Saúde, instalação do laboratório, médicos especialistas, plantão odontológico, aparelho de ultrasson e atendimento oftalmológico em escolas da comunidade (ATA No 2).

\footnotetext{
${ }^{1}$ A função do Diretor Executivo da SESAU é, dentre outras, promover, coordenar, acompanhar e avaliar o desempenho da execução orçamentária e dos recursos pertinentes; acompanhar e avaliar as atividades dos diferentes órgãos subordinados através da avaliação constante dos resultados por meio de análise de relatórios, dados, pesquisa, levantamento, (...) (Regimento da SESAU)
} 
Como respostas, foram informados da criação de um laboratório da rede do município e no centro da cidade. Quanto aos médicos, existia a possibilidade do concurso público.

Nesta $2^{\mathrm{a}}$ reunião, ficou combinado que as próximas reuniões seriam marcadas mais ou menos de 15 em 15 dias, conforme calendário a ser elaborado pelo Grupo Gestor.

\subsection{A. ASPECTOS DO FUNCIONAMENTO DO CONSELHO GESTOR DE SAÚDE DO CRS “Dr. JOSÉ GERALDO ABUHASSAN" VILA ALMEIDA - DISTRITO OESTE - 1994/2002}

\subsection{A.1 PERIODICIDADE DAS REUNIÕES}

As datas, no ano de 1994, indicam que houve apenas 5 reuniões. A periodicidade variou de 18 a 81 dias, sendo a última reunião registrada em 31/08/94. Em 1995, aconteceram 8 reuniões, sendo que duas delas não apresentaram quorum, mostrando também instabilidade na periodicidade, com intervalos de 14 a 35 dias, havendo paralisação de 26/06/95 a 05/09/96 - 14 meses! No ano de 1996, foram realizadas somente 4 reuniões, das quais, uma sem quorum, com intervalos de 21 e 45 dias, voltando a se reunir novamente somente em 20/06/97 - 7 meses de paralisação. No ano de 1997, aconteceram 6 reuniões, com intervalos variando de 21 a 62 dias e concluíram o ano com uma certa sistematização. O ano de 1998, vivenciou 9 reuniões, uma delas extraordinária, com intervalos variando entre 12 e 70 dias mostrando, entretanto, maior sistematização dos encontros. No ano de 1999, as datas indicam que o CG vinha se solidificando, pois realizou 17 reuniões com intervalos, variando de 4 a 45 dias e com maior presença da comunidade nas reuniões. Em 2000, a periodicidade diminuiu, apresentando 12 reuniões, uma delas extraordinária e com intervalos de 21 a 45 dias. Quero acreditar que estes intervalos indicam uma rotina mais estabilizada. Em 2001, aconteceram 6 reuniões, com intervalos de 7 a 35 dias e, em 2002, também 6 reuniões, com intervalos médios de 23 a 35 dias e com dois momentos de pausa - 90 e 120 dias. 
Constata-se, nos 4 primeiros anos, um caminhar trôpego, com reuniões sem quorum e com intervalos muito grandes e incluindo paralisações. De 1998 para cá, o CG parece que consegue se firmar melhor, através de um número maior de reuniões e com periodicidade mais estável. Vê-se, também, algumas mudanças na composição, sem o periodo de gestão estar concluído, pelo abandono de titulares e por demais motivos: desinteresse, falta de tempo, envolvimento com outras atividades, desinformação do papel do CG, reduzida credibilidade no papel do CG dentre outros. O cenário de 2002 mostra-se com dinâmica mais lenta, com 6 reuniões e uma pausa de setembro/02 a jan./03 e com realização de novas eleições.

TABELA 12 - Periodicidade das reuniões do Conselho Gestor de Saúde do CRS "Dr. José Gilberto Abuhassan" V. Almeida - Distrito Oeste - 1994/2002

\begin{tabular}{|c|c|c|c|c|c|c|}
\hline ANO & $\begin{array}{c}N^{\circ} \\
\text { REUNI } \\
\text { OES }\end{array}$ & $\begin{array}{c}\text { Média de } \\
\mathbf{n}^{\circ} \\
\text { presentes }\end{array}$ & $\begin{array}{c}\text { PERIODICIDA } \\
\text { DE }\end{array}$ & PARALIZAÇŌES & $\begin{array}{l}\text { ELEIÇŌES } \\
\text { PARIDADE }\end{array}$ & COORDENADOR(A) \\
\hline 1994 & 5 & 13.4 & 18 - 81 dias & 5 meses e meio & $\begin{array}{l}25 / 02 / 94 \\
4: 2: 2\end{array}$ & Usuário \\
\hline 1995 & 8 & $\sim 4$ & $14-35$ dias & $\begin{array}{l}2 \text { sem quorum e paralisação de } 14 \\
\text { meses e meio }\end{array}$ & & \\
\hline 1996 & 4 & 10 & $21-45$ dias & $\begin{array}{l}\text { I sem quorum e paralisação de } 7 \\
\text { meses (até jun./97) }\end{array}$ & & \\
\hline 1997 & 6 & 7 & $21-62$ dias & & $\begin{array}{l}22 / 08 / 97 \\
4: 2: 2\end{array}$ & Usuário \\
\hline 1998 & 9 & $\sim 7.5$ & $12-70$ dias & & $\begin{array}{l}6 / 03 / 98 \\
4: 2: 2\end{array}$ & Usuário \\
\hline 1999 & 17 & $\sim 11.4$ & $4-45$ dias & & $\begin{array}{l}22 / 10 / 99 \\
4: 2: 2\end{array}$ & Usuário \\
\hline 2000 & 12 & $\sim 5.8$ & $21-45$ & & & \\
\hline 2001 & 6 & 12 & $7-35$ & & & \\
\hline 2002 & 6 & 9.6 & $\begin{array}{l}23-120 \\
\text { dias }\end{array}$ & $\begin{array}{l}\text { PAUSA - } \\
\text { Maio - agosto ( } 3 \mathrm{~m} \text {.) } \\
\text { Set. - jan. } / 03 \text { ( } 4 \mathrm{~m} .)\end{array}$ & & \\
\hline
\end{tabular}




\subsection{A.2 COMPOSIÇÃO DO CONSELHO GESTOR}

A escolha dos conselheiros aconteceu na $1^{2}$ reunião, perfazendo número paritário 4:2:2, com a composição de $\mathbf{4}$ usuários: $\mathbf{2}$ trabalhadores: 2 prestadores de serviços. Estiveram presentes usuários dos bairros Almeida I e II, Coophatrabalho, Santo Amaro, Palmira I e II, Assentamento Social Jd. "José Pereira". Ainda, prestadores de serviço, assistente administrativo, auxiliar de serviços diversos e trabalhadores de saúde (assistente social e auxiliar de enfermagem). Demais eleições ocorreram, conforme descrito acima, mantendo-se a paridade da $\mathrm{l}^{\mathrm{a}}$ eleição.

\subsection{A.3 - REPRESENTATIVIDADE - ATORES}

A representação era realizada pelos líderes comunitários, associações de moradores, catequista, gerente do Distrito Sanitário e Pastoral da Saúde e da Criança. As reuniões eram feitas na capela N. Sra. da Misericórdia. Posteriormente, passaram a ser feitas na sala de reuniões do CRS, construída para fins educativos e social, fruto das reformas iniciadas em 1999. Esta representação não garantia representatividade efetiva.

O processo de eleição de conselheiros iniciava-se com a divulgação da eleição, corpo-acorpo e/ou convites por escrito para entidades e apresentação de nomes para novos conselheiros na reunião da eleição. Caso necessário, completava-se os conselheiros usuários, funcionários e suplentes com novas indicações.

Neste CG, a coordenação sempre foi de conselheiros usuários. A figura da(o) gerente da Unidade é sempre percebida nas Atas, ora mais ora menos envolvida(a) e, junto com a chefe do Distrito, reitera a importância, os objetivos e a necessidade da participação sistemática dos conselheiros usuários na divulgação do papel do CG. Esta divulgação seria através de visitas e reuniões na comunidade, nas casas dos conselheiros para divulgar a atuação do Conselho e fortalecer o grupo. Os conselheiros deveriam, ainda, preparar o aviso e distribuí-lo para locais de bens e serviços.

Ficava delegada aos conselheiros a identificação de problemas, a execução de alguns serviços - acompanhamento e conversa com as pessoas nas filas de agendamento, na observação e supervisão informal dos setores da Unidade, dentre outros (ATAS). 
Nas reuniões, estavam presentes os conselheiros usuários e que, em algumas vezes, se faziam acompanhar de outros usuários daquele CRS. O presidente da associação de moradores não é uma figura atuante nas reuniões e na busca das soluções para os problemas colocados e discutidos. A população propriamente dita, raramente, comparece a alguma reunião.

No segmento prestadores de serviços, o(a) gerente do CRS em questão e mais um funcionário tem estado presente, e a chefe de Distrito quando se faz necessário o repasse de informações, orientações pertinentes àquela Unidade e/ou área de abrangência do CRS. Em uma das reuniões assistidas, com a presença da Chefia do Distrito Oeste, pude observar, na fala deste profissional, um estímulo à participação efetiva da comunidade e um chamamento aos conselheiros para estarem no papel de gestores. Prestadores de serviços da SESAU - Controle Social, Vigilância Sanitária, assistente Social e Secretário(a) de Saúde -, têm estado presentes quando a situação exige maiores esclarecimentos ou quando surgem problemas, aparentemente, sérios.

Quanto aos trabalhadores de saúde da Unidade, formado pelo corpo de enfermagem, têm estado sempre prontos a discutir e analisar as questões levantadas, indicando para as problemáticas apresentadas possíveis caminhos e soluções apesar de, muitas vezes, existirem pontos de vistas distintos. O corpo clínico fez-se presente, com maior expressão, nos primeiros anos de funcionamento do CG. Presentes também outros atores sociais como agentes de saúde da FUNASA, agentes de saúde comunitários (PACS) e, vez ou outra, acadêmicos de enfermagem da UFMS, ligados à disciplina de Administração em Enfermagem.

O registro do CG deste CRS aconteceu no dia 23/03/98 no Cartório do $4^{\circ}$ Oficio. Aliás, necessidade para ser reconhecido como entidade pela PLANURB e poder participar no seu Conselho. Documentos solicitados do tipo Oficios encaminhados e outros, para se perceber melhor os tipos de encaminhamentos não foram entregues dentro do tempo previsto, aliás, a própria coordenadora declarou: não podemos mostrar nossos documentos prá não falar mal do Prefeito (entrevista), desconsiderando a autorização da pesquisa pela Secretária de Saúde e que tais documentos são públicos. 


\subsection{B. DINÂMICA DO FUNCIONAMENTO DO CONSELHO}

\section{GESTOR: a prática de atuação do conselho}

Nas primeiras reuniões, as demandas apontavam para as necessidades: atendimento médico, odontológico e administrativo na Unidade, ainda, campanha de vacinação com responsabilidade e idoneidade dos vacinadores, treinados e honestos quanto aos nimeros dos vacinados. $\mathrm{O}$ estado do Mato Grosso do Sul se propunha também a dar assistência aos CG. Seria importante, a informação e sensibilização para o bom desempenho das campanhas, pois a mobilização da comunidade é imprescindivel para disseminar idéias, pois quem participa tem condições de repassar a informação (ATAS).

Mostrava-se, no CG, a preocupação com gravidez de adolescentes, pois a Unidade e demais Unidades do município recebem adolescentes com 10-11 anos, já grávidas. $O$ momento da reunião era, também, usado para ouvir reivindicações e informar as ações desenvolvidas pela Unidade, na região: campanha de câncer de pele, retorno do Programa do Leite e dias para atendimento aos diabéticos. Muitas reivindicações de lideranças de bairros não são descritas. Definir o papel do $C G$ é uma preocupação constante. Relatavam limites para atuação do profissional de saúde dentro da Unidade, mas não são relacionadas.

O CG passou por algumas paralisações e pausas. Novos participantes da comunidade apareceram interessadas em fazer parte do CG para atuarem no gerenciamento do CS.

No ano de 1994, foi elaborado o Estatuto do CG, orientado por um Estatuto de outra Unidade Regional, já efetivado. No mês de março/95, discutia-se a reestruturação da Unidade de Saúde do bairro Santa Carmélia, região de abrangência do CRS que, de acordo com informações de enfermeira deste CRS, conformava-se em uma Unidade de infra-estrutura muito simples e que, atualmente, está desativada. 
Os conselheiros precisam ser seguidamente substituidos por seqüência de ausências. Por vezes, são indicados, por vezes, oferecem-se para participar e preencherem as vagas

A partir da $3^{a}$ reunião, a dinâmica de trabalhos começou, de acordo com as Atas, com debates voltados para as suas necessidades e atividades já programadas e propostas pela SESAU como campanhas, Programas, construções, rotatividade de funcionários, dentre outros.

A nova Secretária de Saúde (1998), quando de sua posse, foi conhecer a Unidade e disse que pretendia fortalecer os CG.

\section{QUEIXAS DO CONSELHO GESTOR DE SAÚDE DO $C R S$ "Dr. JOSÉ GERALDO ABUHASSAN" - V. ALMEIDA - DISTRITO OESTE - 1994/2002}

\section{SITUAÇ̃̃O EPIDEMIOLÓGICA}

As questões epidemiológicas são poucas e se relacionam a preconceito para tomar vacinas - pouca informação pela mídia; à falta de higiene com as máscaras de inalação; as casas não têm fossa e jogam água servida no quintal causando mau cheiro; há falha no recolhimento do lixo municipal. Os cidadãos têm dificuldade de comprar sacos de lixos, colocam em caixas grandes e os maiores problemas estão em ruas que não tem asfalto. Cita-se ainda situação caótica nos comodatos quanto ao problema do lixo. A lei prevê multa para tais pessoas, mas somente quando pegas em flagrante. O problema foi passado para os agentes do PACS para verificar e avisar o CG sobre as condutas tomadas (ATAS).

Problemas de queimadas, falta de saneamento, escoamento de águas servidas, supermercados e lava-jatos clandestinos - a Vigilância Sanitária não consegue chegar a uma solução (ATA, p. 46). Por três reuniões seguidas houve queixa quanto à limpeza do CRS nos finais de semana. 


\section{SERVIÇOS DE SAÚDE}

Farmácia fechada à noite foi queixa por muito tempo. O Conselho insiste no horário de atendimento até às $24 \mathrm{~h}$. A falta de medicamento é justificada com a alta do dólar. A farmácia tem mau atendimento e foi alvo de séria denúncia: funcionária de serviços gerais divide horário com bioquimica na distribuição de remédios controlados. Falta espaço para guardar medicamento, diz farmacêutico. O que fazer para quem, da farmácia, passou remédio errado, não só uma vez? (ATAS).

Falta de pediatra, de plantonista, de plantão clinico no domingo, de atendimento odontológico, perda de médicos e plantonista na quarta e sexta-feira porque não podem fazer dois plantões seguidos, incomodam os conselheiros. Ainda, médico que não encaminha para especialista o não fornecimento de atestados médicos no plantão, remédios de uso continuado não receitado para 2 a 3 meses. Existem queixas quanto à postura do médico: atenção nenhuma aos pacientes em relação ao atendimento médico - o profissional médico, nem olha no olho do paciente; médicos pediatras não puderam seguir o esquema do pronto atendimento. Os plantonistas clínicos pediram dispensa, alegando fatores econômicos e descontos abusivos de impostos. Falta de profissionais médicos; falta de pediatra aos sábados e domingos e ausência de pediatra nas Unidades $24 h$., incomoda, seriamente, a população (ATAS).

O CRS perdeu médicos que prestavam serviços fundamentais e o serviço de informação deixa a desejar. Há médicos plantonistas que não estão cumprindo horário, não esperam a substituição. Um médico não examinou devidamente o paciente e no dia seguinte, terminou em cirurgia urgente. Alguns profissionais resistem ao encaixe de consultas, com exceção de clínicos e odontólogos, podendo comprometer a produtividade. Existem advertências para médicos que faltovam demais. Porque tantas enfermeiras padrão fazem plantão? (ATAS).

Ocorria tumulto no final do mês para marcar dentista. É marcado em um dia para todo o mês e isto atrapalha o sono dos vizinhos da Unidade. Os usuários do CRS reclamam do mau atendimento da recepção, mas, contraditoriamente, existem, também, agradecimentos em relação ao atendimento. Registra-se, ainda, o desrespeito dos 
seguranças com os funcionários. A vacina fecha no almoço e à tarde. Ocorre atraso de médicos plantonistas na troca das 7 h., e sobrecarga no 24 h., pois acaba atendendo ambulatório. O Diário Oficial do município publicou que enfermeiras iriam fiscalizar os horários de saida e chegada dos funcionários da Unidade (ATAS).

Questões pertinentes ao bom funcionamento da Unidade estão sempre em debate: segurança - roubos, violência (os pacientes não querem esperar), armas, dentre outros. Bebedouros, equipamentos como aspirador de secreções, por exemplo, e limpeza da Unidade entram em pauta para debate, também.

Foi encaminhado convite ao Secretário de Saúde para participar e discutir problemas do CRS. Esta postura explica a seguinte afirmação: não adianta elencar os problemas que ocorrem neste CS porque todas as vezes que se solicita a presença da Chefia do Distrito não resolve, pois a mesma não compareceu na reunião do CG" (ATA, p. 44). Os conselheiros pediram maior atenção do Distrito porque a Unidade teve o maior número de atendimentos e procedimentos no mês de maio/2001.

A falta de espaço, de informação correta para a recepção, em horário de troca de plantão, são queixas que se repetem. Pedem mais organização, inclusive, no horário da troca de plantões. Reclamam também do corpo de enfermagem: mau atendimento $e$ falta de interesse para as crianças com febre alta que aguardam por várias horas. Uma funcionária olhou a pressão errada de usuário e foi advertida pela diretora. Da fila: fila única para todas especialidades e não se avisa no fim da fila que não há mais vagas; perde-se tempo. Erro de datas nas consultas do Centro de Especialidades Médicas; ficha de paciente do Programa do Hipertenso não tinha notação da pressão. Lamenta-se a retirada de uma enfermeira, pois se mostrou competente e foi pedido seu retorno (ATAS).

Reclamam, ainda, que a Unidade é usada por moradores de vários bairros e fora da capital, reduzindo as vagas. Para piorar, houve roubo do aspirador de secreção na emergência e não há ventilador na sala de espera e na sala de repouso (ATAS). Neste 
aspecto do atendimento de usuários de vários bairros, os conselheiros não podem interferir, pois estariam ferindo o principio da Universalidade do SUS.

Os usuários deixam registrado que a região de maior precisão ficou descoberta pelos agentes do PACS. O CRS está se transformando em um grande ambulatório e com desvio na função de urgência. Um líder comunitário afirmava ser necessário esforço sobre-humano dos funcionários para administrar o estado caótico da Unidade, por causa de muita demanda (ATAS).

Dizem os conselheiros que as informações não podem ser sonegadas, é direito do usuário. Há dificuldade em marcar dentista e a Unidade está camuflando a demanda. Os agentes do PACS querem marcar na frente, não entram na fila para marcar a consulta. Mas isto já não acontece mais. Existe também dificuldade de agendamento pelo setor de Informática e não há digitador suficiente. A preocupação com a digitadora deve-se ao fato de grande demanda e quando não é digitado, não se fatura. Reclamam ainda que as consultas de diabéticos são de 3 em 3 meses e noutras Unidades é semanal (ATAS).

Os serviços de imunização e inalação também são alvos de críticas. Explicam os trabalhadores de saúde da Unidade que faltam recursos humanos porque eles cobrem vários setores e existe número reduzido de auxiliar de enfermagem no CRS, pois houve remanejamento de funcionário para farmácia e ultrasson. Relatam aglomeração e tumulto, choro e gritos dos idosos porque o atendimento dos Programas começa tarde. Os Programas de Tuberculose e Hansen não estão funcionando normalmente. Pacientes buscam informação do $24 \mathrm{~h}$. no ambulatório; buscam atendimento imediato na UBS e quando não conseguem, costumeiramente, dirigem-se até ao CRS, causando tumultos (ATAS).

O espaço na Unidade é muito disputado: a sala de reunião e de repouso é muito pequena; há necessidade de sala para o PACS, pois a existente seria desativada pela Odontologia. 
Os trabalhadores de saúde também reclamam: agentes de saúde que trabalham com veneno não têm equipamento de proteção e não ganham insalubridade; alcoólatras aidéticos não aceitam tratamento do CRS, então, não se responsabilizarão mais pelos mesmos. Pacientes faltam nas consultas agendadas para CEM e, conforme os médicos, muito atendimento põe o CRM em risco. O grande atendimento na Pediatria causa desgaste no profissional. A maior parte do atendimento do 24 h. é de ambulatório (ATAS).

A comunidade sempre pede o uso da ambulância para transporte de pacientes, mas a SESAU orienta que ela seja usada somente para urgências e emergências. Tem sido complicado para a comunidade entender esta postura, pois são carentes e poucos dispõem de veículo particular. A mesma coisa aconteceu com a cadeira de rodas solicitada por um usuário e a enfermeira não emprestou a cadeira de rodas para trazer paciente.

Gerente do CRS comunicava sucesso da Campanha da Mama e dia D anti-dengue. Com a posse da nova Secretária, a Unidade passaria por várias mudanças: reordenamento das atividades do $\mathrm{CRS}$, estabelecimento de novas atribuições, implantação de equipe multidisciplinar para os Programas de Saúde, critérios para o uso da ambulância, implantação dos Programas de Saúde da gestante e do Hipertenso, Campanha da Febre Amarela e Campanha Nacional do Câncer, Saúde Bucal;

Os conselheiros são informados sobre a questão do agendamento de consultas, o qual estava funcionando, ainda, com algumas falhas. A questão problemática do agendamento nas especialidades médicas deveria ser normatizado pela SESAU para todas as Unidades de Saúde. Havia questionamento do ultrassom.

Conselheira visita CRS à noite e identifica urgências para serem atendidas: vômito, febre e avisa a Enfermagem. De acordo com uma trabalhadora, alguns conselheiros parecem que querem intimidá-los, pois algumas vezes, pegam o usuário pelo braço e o levam até à pré-consulta, dizendo que está demorando o atendimento. 
Os conselheiros pediam ao Distrito maior atenção para a Unidade, que teve o maior número de atendimentos e procedimentos no mês de maio/02. Tem-se, então, reunião para discutir reivindicações com chefe do Distrito.

Os conselheiros reclamavam que, na reforma constitucional, não foi definido o montante de recursos a ser destinado à saúde pelo municipio, ficando os recursos sempre muito comprometidos. O RX está quebrado e o conserto é caro, quase o preço de um novo, e o Distrito irá ver a questão na SESAU (ATAS).

A Secretária de Saúde foi questionada sobre a troca de administrador do CRS sem a consulta ao Conselho. O CG questionou, também, o desmembramento do CRS da UBS, ambos no mesmo prédio, sem consultar os conselheiros. Isto iria implicar em necessidade de um enfermeiro para o $24 \mathrm{~h}$. e outro para o ambulatório. A Unidade de Saúde precisa de profissionais enfermeiros e não outro gerente e por conta do desmembramento (ATAS).

A coordenadora do CG foi conversar com assessoria do Prefeito para solicitar esclarecimento sobre a divisão da Unidade. De acordo com um dos conselheiros usuários, dois chefes, juntos, fica dificil trabalhar. Neste impasse, a nova gerente da UBS assumiu, entremeio a descontentamentos, e perguntava: qual a função do CG? Tal pergunta estimula o pensamento de ignorância quanto ao papel do $C G$, mas, na realidade, conforme depoimentos de funcionários da Unidade, poderia ter sido um momento de aparente ironia, dada a pressão do CG sobre a decisão administrativa na UBS. Pelo registro das Atas, não consta como foi a deliberação para a troca da gerente. Esta postura do CG parece evidenciar uma insatisfação pelo fato de o desmembramento ser feito por uma decisão superior e a "afronta" à primeira gerente pode significar uma afronta ao setor e não à pessoa da gerência, pois o poder de decisão do CG fora desconsiderado. Em maio de 2002, a coordenadora do CG, que era contra o desmembramento do CRS, concordava com o desmembramento para conformar a UBS. Em entrevista com esta coordenadora, ela afirmou que "brigaram" com o Distrito $e$ reivindicaram, então, a enfermeira que eles conheciam (ATAS). 
De acordo com a coordenadora atual do CG, deliberar significa sugerir e não mandar, não executar e só deliberar; batalhar é negociar, é não arredar o pé. Sou tida como ranzinza, mas me respeitam. Afirma ainda que o interesse do CG é ter o profissional afinado com a comunidade e não devem brigar. Disse que conquistaram o Distrito para desmembrar o CRS para UBS (entrevista). Na realidade, o que eles conquistaram foi o direito de escolher a gerente da UBS, naquele momento, conforme diz uma funcionária da Unidade.

\section{SETOR SAÚDE}

A SESAU mantém equipes para fazer supervisão e uma destas equipes chegou para historiar as atividades no CRS, acredito, que seja pela demanda das críticas e reclamações. Nos registros das Atas consta que chegaram sem ética e sem nenhum constrangimento; entrou na sala de urgência (...), os funcionários foram abordados na recepção de forma agressiva e em tom de alta voz, perante os usuários e fizeram ameaça: trocariam a equipe da recepção (ATA p. 31).

Os conselheiros reclamam que para a troca de direção do CRS eles não eram consultados. $O$ trabalhador explicava: ela é competente e o CG só pode avaliar depois que assume o cargo. Desde 1995, o Distrito põe e tira funcionários enfermeiros sem comunicar. O Distrito tirou uma enfermeira porque disse que não gostava do serviço dela. Uma conselheira muito ativa dizia que um Diretor do CRS, substituido, foi podado e teve dificuldades para melhor desempenhar suas funções. Acredita-se que foi marcação de alguém, pois foi encontrado um sanduíche, aberto, dentro da geladeira de vacinas e uma cueca dentro da autoclave. Foi taxado de incompetente pelo Prefeito. A saida da assistente social e da psicóloga não foi comunicada ao CG. Relatam que na fala da Secretária de Saúde, dificilmente, dá para participar (ATA, 23/03/00).

Os serviços do CRS vêm sendo usados mais como ambulatório notumo do que para urgências e emergências. A explicação mais plausivel se sustenta nas questões sociais, pois os usuários, necessitando dos serviços e trabalhando durante o dia, não se dispõem a ir para o ambulatório da UBS para não perder dia de serviço, fazendo-o após o expediente. $E$ nesse debate, o $\mathrm{CG}$ tem sempre procurado opinar para uma melhor 
direção. Esta é uma questão que atravessa os anos 90 no município de Campo Grande/MS, com pouco avanço para sua resolução.

Os conselheiros queriam ter acesso ao livro de ocorrências internas. Foi-lhes negado, pois só é permitido aos funcionários. Foi dito aos conselheiros que eles não tem competência de interferir na administração; podem dar sugestões (Ata, p. 42). Os conselheiros pedem mais respaldo, principalmente, do Distrito.

\section{SUGESTÕES dO CONSELHO GESTOR DE SAÚdE DO CENTRO REGIONAL DE SAÚDE "DR. JOSÉ GERALDO ABUHASSAN" - V. ALMEIDA - DISTRITO OESTE - 1994/2002}

\section{ASPECTOS EPIDEMIOLÓGICOS}

Água tratada sempre era reivindicada no Conselho por lideranças de bairro que ainda se serviam de água de poço. Um cidadão solicitava ao CG e direção do CRS uma parceria para tentar sanar o problema da drenagem da região do bairro (...), sendo, naquela ocasião, atendida com água de poço. A população tinha risco de saúde, com fezes a céu aberto (ATAS).

Considerando alguns preconceitos em campanhas de vacinação, sugere-se a busca de maior abertura da midia para as referidas campanhas. Ainda, a confecção de cartazes para murais para se manter a limpeza da Unidade e não trazer animais ao Centro de Saúde (ATAS).

Em 18/02/00, os moradores reivindicavam cascalhamento de ruas e arrumação de ponte para ligar bairros, fazer creche, melhoria da praça e em parceria com a comunidade. Ruas sem cascalho dificultam e até impedem passagem dos caminhões coletores de lixo, comprometendo o saneamento básico de bairros. Tinha-se a resposta: não era possível contar com a Prefeitura, naquele momento. 
As questões da Dengue estão sempre presentes nas reuniões. Todos os conselheiros são conclamados a ajudar a combater a Dengue e supervisionar as ações dos agentes do PACS nas micro-áreas, principalmente, na ajuda do combate à dengue, pois se a população não jogar as bugigangas fora e depois, se não der certo, dizia a Chefe do Distrito, critica o governo. Ainda, a Chefe do Distrito pedia à coordenadora do CG conseguir espaço para entrevistas e palestras nas rádios comunitárias, igrejas, rádio da Universidade Católica Dom Bosco - UCDB, e Universidade para o Desenvolvimento dos Recursos do Pantanal - UNIDERP, solicitando, inclusive, a divulgação das ações de saúde que acontecem na Unidade (observação de reunião).

\section{SERVIÇOS DE SAÚDE}

O CRS tem demanda por equipamentos que possam dar diagnósticos que agilizem o atendimento como aparelho de eletrocardiograma, ultrasson, RX e salas para observação de pacientes, as quais necessitam de camas para observação e que, às vezes, faltam. Há demanda de 60-65 pacientes por periodo e vez ou outra, o CG pede remanejamento de funcionários e que seja servidor de respeito.

O CG sugeria o uso do Hospital Evangélico para plantões e atendimento ambulatorial, por conta da grande demanda pela urgência e emergência. Ainda, médico no horário de almoço, maior rigidez da SESAU para os médicos do plantão, reposição de auxiliar de enfermagem pelo Distrito, pois a rotina estava estafante. Resposta negativa. Sugeriam retorno de médico para plantão na sexta-feira. Um conselheiro sugeriu que a Diretora do CRS resolvesse a escala de plantão noturno sem esperar pela SESAU, pois ela atravancava o desenvolvimento e não dava solução. Era preciso mais autonomia do CRS. O CG recebe um recado que, para medicamentos e escala de plantões, a gerente da Unidade deve ter iniciativa própria.

Os médicos discutem um modo de produtividade: ser paga para o servidor com base na demanda diferenciada de cada CRS e UBS, para quem, realmente, produz e estaria vinculada ao número de pacientes atendidos por categorias, tanto médicos, enfermeiros, auxiliar de enfermagem, dentista e administrativos. Esta questão está em estudo e é uma iniciativa dos médicos. A justificativa é pelo fato de este CRS ter uma demanda muito 
superior nos plantões quando comparado com demais CRS e o valor pago pelo plantão ser o mesmo (ATA, p. 44).

A questão dos médicos sempre é, intensamente, discutida. Pedia-se a contratação de médicos. A resposta foi que não era possível contratar mais médicos, não havia concursados, somente para plantões eventuais. Sugerem lotar médico com dois períodos na Unidade e plantões médicos rotativos nos finais de semana. Ao invés de o Prefeito dar passe livre dois domingos por mês, que se dê mais um administrativo para o CRS, porque passe livre é enganação; alguém está pagando por ele. Então, que seja dirigido esse dinheiro para as Unidades de Saúde. Ainda, a aquisição de TV e video para melhor desenvolver os trabalhos de palestras, sendo que a TV e Video deveriam ser solicitados $\grave{a}$ Receita Federal, como doação ao CRS para fins educativos e de informação (ATAS).

A UBS, também, tem grande demanda e o CG solicita acadêmico de medicina, mas que também aumente o número de médicos e, naquele momento, a solicitação era médico com vínculo ambulatorial. Pedia-se, também, Ortopedia no CRS; mais um dentista plantonista, devido à intensa demanda, um dentista no horário intermediário(17-21h.) e ambulância social para atender a comunidade (ATAS).

Mais segurança para médicos sempre foi reivindicação devido à Unidade ter várias entradas e pacientes que não querem esperar pelo atendimento. Os usuários interrompem atendimento de emergência, chamando na porta (ATAS). Já conversei com profissionais durante minha atuação como docente da UFMS nos anos 96-97, que portavam armas no seu consultório como legitima defesa. Hoje, esta questão está mais amenizada.

Os conselheiros usuários deixam nítido, nas Atas, a necessidade de um melhor acolhimento na fila, necessária a agilização no atendimento e encaminhamentos necessários, fato este que sempre se confrontou com um reduzido corpo de funcionários, muitos deles, em muitas situações e momentos, atendendo dois setores, paralelamente. Tem-se a necessidade de bebedouros que não foram previstos na reforma e ampliação do CS. 
Um Mural foi solicitado pelo gerente do CRS, como instrumento de utilidade pública; cobrir a recepção com vidro para melhor atender, fazer varandões nas laterais da UBS para os usuários fazerem fila fora da Unidade, cadeiras para sala de reuniões, $T V$, video e interfone, construção de sala para mamografia, dentre outros, são sugestões para suprir várias necessidades de infra-estrutura (ATAS).

O movimento de usuários dentro do CRS ainda se mistura com os da UBS, trazendo transtornos para a recepção. Foram solicitadas divisórias para separar o local de atendimento da pediatria, desmembramento do ambulatório da Unidade $24 \mathrm{~h}$, organização na parte do ambulatório e necessidade de gerente eficiente para o ambulatório. O CG requisitou a permanência de enfermeira no CRS e melhorias na estrutura física de seus consultórios, e o Distrito pediu à coordenadora do CG chamar a população para conhecer os serviços prestados (ATAS-QUESTIONÁRIO). A Chefe do Distrito afirmava que era preciso ouvir as críticas, "engolir" e ver o lado bom para refletir e "peitar as coisas" e dizia que "se você me enfrenta, eu te respeito" (observação de reuniões).

Sugeriam, freqüentemente, que a farmácia ficasse aberta até às 00:00h., que remédios controlados fossem entregues também por funcionário e não somente pela farmacêutica e que um administrativo digitasse as receitas da farmácia para reduzir a fila; que fosse implantado plantão das 6h. à meia noite. Também, divulgar a tabela de atendimento ginecológico, colocado em prática no pronto atendimento. Ainda, trocar segurança, porque dormiam e estavam doentes e desequilibrados. Ainda, providenciar com urgência um farmacêutico; enfermeiro para transcrever receita e indicavam nome para gerência da UBS (ATAS).

Os agentes do PACS são mal recebidos por falta de medicamentos. Deveriam orientar que isto não é responsabilidade deles $\mathrm{e}$, ainda, repassar por escrito as situações ambientais irregulares encontradas em suas áreas para serem repassadas para a Vigilância Sanitária, eram sugestões registradas em Atas. 
Conselheira defendia que $o C G$ devia ser consultado para trocar funcionários, gerentes e enfermeiros, pois o CG tem autonomia. Pedia-se, inclusive, averiguação do destino dado à verba que era destinado à obra. Foi lembrada a necessidade de se ter espaço para o destino do lixo hospitalar no processo de reforma da Unidade (ATAS).

Quanto aos serviços de Odontologia, sugeriam um plano de endodontia em mutirão em bairros e serviços de endodontia nos CRS. Ainda, disponibilizar vaga para dentista quando um cliente terminar o serviço completo; relacionar por ordem de chegada $e$ chamar por telefone quando abrisse vaga (ATAS).

Propunham um funcionário para dar informação na recepção e acolhimento dos pacientes na fila. Ou, considerando-se a grande demanda da Unidade, que se tivesse uma só entrada com guarita de informação com acolhimento e informação na fila. Também, trabalhar com a comunidade para definir o que é ambulatório de emergência; por TV para distrair os usuários idosos e demais, através de campanha para se obter dinheiro, horário fixado para entrega de remédios controlados quando a farmacêutica não está, melhorar o sistema de informática da farmácia, atualizar e simplificar a ficha de atendimento, discutir o que é implantação de senhas eletrônicas; rever atendimento do CRS (ATAS).

Os trabalhadores e prestadores de serviços também têm suas reivindicações, como por exemplo, incentivos para plantonistas nos finais de semana, providências para sol no rosto de funcionário - na forma de toldo para recepção, pré-consulta e farmácia, grade na recepção para garantir maior segurança física $e$ bebedouro com água gelada $e$ filtrada para funcionários. O Farmacêutico pediu aumento no espaço físico da farmácia e, ainda, eram necessários, ventiladores, camas e ar condicionado para o repouso médico (ATAS).

Sugeriram que a presença de equipe multiprofissional é mais viável na UBS e não, no CRS. Deveriam apresentar um Projeto sobre a UBS, agendar todas as consultas para constatar a demanda reprimida, regionalizar atendimento devido à falta dos pacientes nos exames marcados, unificar os Programas, criar sub-código para diferenciar o 
faturamento do 24 h. e ambulatório, desmembramento do CRS da UBS e fazer acolhimento com carinho (ATAS).

Muitos usuários têm dúvidas após as consultas em relação a vários aspectos. O CG propôs implantar o Projeto TIRE DUVIDAS - com objetivo de orientar o usuário na pós-consulta, por telefone, e avaliar a necessidade de consuita, também, por telefone, antes de o usuário se dirigir a Unidade de Saúde, com vistas a reduzir a demanda. $\mathrm{O}$ Projeto não foi desenvolvido.

A sala de reuniões precisava de mais cadeiras para momentos educativos. As que existem foram ganhas da escola ao lado e estão em número insuficiente, pois o espaço abriga as reuniões dos Programas de Saúde, do Conselho Gestor, dentre outras.

Avaliação é um tema que vez ou outra aparece. Para a Chefia do Distrito, os serviços de saúde precisariam ser avaliados com cuidado - o que está sendo oferecido para a população e as condições de trabalho dos servidores para não causar situação que comprometesse a qualidade desses serviços (ATAS).

\section{SETOR SAÚDE}

Era colocado como necessidade para os conselheiros assistirem reuniões do CMS e do Fórum dos Usuários do SUS. Há necessidade de sensibilização sobre os problemas e da tomada de decisões para melhoria dos serviços e capacitação dos conselheiros. Foi afixado no CRS Poster para chamamento de pessoas para participarem do CG (ATAS).

O CG, ainda não oficializado na PLANURB, deveria fazê-lo para participar dos eventos em 1999. Sugeriam curso de capacitação para conselheiros e contratação de pediatras e clínico geral concursados, pedidos via Oficio à SESAU.

A Diretora do CRS pedia reunião extraordinária do CG para discutir sobre Programação de 2000 , do que foi feito e o que se realizou, e planejar a Programação de 2001. Nesta reunião, com dez membros presentes, fez-se a leitura do documento "Diretrizes de 
Saúde para $2001(21 / 02 / 01)$ ". A fiscalização e a administração dos $11 \%$ do financiamento para a saúde do município foi lembrado em uma das reuniões.

O setor de Controle Social da SESAU orientava que se fizessem reuniões na comunidade para explicar como funciona o $C G$. O Distrito orientava que as propostas devem ser fundamentadas com os argumentos, registrando em documento (Atas) para posterior análise de todos os pontos e viabilidade pela SESAU (ATAS).

A ampliação do CRS atrasou e sugeriram o encaminhamento de Oficio para Prefeitura e Secretário de Saúde pedindo resposta das questões já discutidas sobre a ampliação da Unidade. Como estratégia, também, pediam a participação do CG no Conselho Municipal de Saúde para seguir mais de perto as obras (ATAS).

Os conselheiros sugeriram que a SESAU tinha que participar das reuniões do CG através de um representante de confiança. Seguidamente isto tem acontecido e estes representantes se fazem presentes de acordo com a problemática existente, havendo participação de vários setores nas reuniões do CG quando solicitados. Mas esta solicitação, também, tem a ver pela necessidade de resolutividade de alguns problemas que o Distrito não estava respondendo.

O papel do CG tem sido sempre lembrado nas reuniões e solicitado aos conselheiros difundir a existência e funcionamento deste serviço do CRS, além de trabalhar com a comunidade, esclarecendo sobre os serviços oferecidos na Unidade, usando-se a divulgação do serviço nas igrejas e meios de comunicação para definir, também, os papéis diferenciados da urgência/emergência $e$ do ambulatório, para reduzir incômodos, tanto para trabalhadores e prestadores de serviços da Unidade quanto aos usuários (ATAS).

A falta de pediatra vem provocando muitas críticas e gerando denúncia em 2002 , no Conselho Tutelar. O Distrito orientava, na reunião do CG que se o Conselho Tutelar visitasse o CRS para saber sobre o atendimento pediátrico, devia-se mostrar quantos atendimentos são realizados pela emergência, quantos são agendados no ambulatório e 
número de faltosos existentes na UBS. Dizia a Diretora do Distrito que nós, servidores, temos que mostrar e não esconder onde é o lugar de lutar (observação de reuniões). Os conselheiros têm se aliado aos agentes do PACS para ouvir reivindicações e encaminhálas para a SESAU. 


\section{QUADRO 08 - DECISÕES/DELIBERAÇÕES DO CONSELHO GESTOR DE SAÚdE DO CENTRO}

REGIONAL DE SAÚDE “Dr. JOSÉ GERALDO ABUHASSAN” - VILA ALMEIDA - DISTRITO OESTE 1994/2002

\begin{tabular}{|c|c|c|}
\hline ASPECTOS EPIDEMIOLÓGICOS & SERVICCOS DE SAÚDE & SETOR SAÚDE \\
\hline $\begin{array}{l}\text { 1.fiscalização para verificar as normas de } \\
\text { higiene de um Canil da região deste CRS. } \\
\text { 2. Conselheiros deveriam orientar a } \\
\text { população para que recebessem os agentes } \\
\text { do PACS em suas casas (p. 17); } \\
\text { 3. Oficio para Vigilância Sanitária sobre } \\
\text { águas servidas no bairro. A Vigilância } \\
\text { Sanitária se propôs a identificar áreas com } \\
\text { sujeiras e detritos na região da grande } \\
\text { Santo Amaro, comprovar com fotos e } \\
\text { encaminhar para CG; } \\
\text { 4. agentes do PACS orientavam aos } \\
\text { presidentes de bairros encaminharem }\end{array}$ & $\begin{array}{l}\text { 1. orientar sobre agendamentos com } \\
\text { especialistas e coleta de material para } \\
\text { exames; } \\
\text { 2. aviso da campanha de incentivo de } \\
\text { aleitamento materno; } \\
\text { 3. os injetóveis ficariam na emergência, } \\
\text { pois a farmácia fecha à noite; } \\
\text { 4. Oficio para bebedouros, vigias e } \\
\text { aparelhos que faltam na emergência; } \\
\text { 5. funcionários de serviços gerais nos fins } \\
\text { de semana, pois o fluxo é grande, ou horas } \\
\text { extras para funcionários; } \\
\text { 6. Programa mutirão de esporte, lazer e }\end{array}$ & $\begin{array}{l}\text { 1. encaminhado documento oficial } \\
\text { recriminando a agressão e falta de ética } \\
\text { pelos servidores da SESAU, na recepção, } \\
\text { quando em visita ao CRS; } \\
\text { 2. O Planejamento Anual da Unidade vem } \\
\text { acontecendo há vários anos com a } \\
\text { participação do CG. O Distrito afirma que é } \\
\text { preciso ter números para planejar e achar o } \\
\text { rumo; } \\
\text { 3. Oficios encaminhados deveriam ser } \\
\text { acompanhados por uma Comissão de } \\
\text { conselheiros para cobrar as solicitações, } \\
\text { principalmente, quando se tratavam das }\end{array}$ \\
\hline
\end{tabular}




\begin{tabular}{|c|c|c|}
\hline Oficios aos órgãos competentes. & $\begin{array}{l}\text { saúde do CRS com atividades de corte de } \\
\text { cabelo, teste capilar, vacinas, orientaçôes, } \\
\text { exames de câncer de mama e video de } \\
\text { aleitamento materno; } \\
\text { 7. colocação de grades divisórias na } \\
\text { recepção para melhorar fluxo de pessoas; } \\
\text { 8. reforma do setor de Odontologia e a } \\
\text { construção de sala de reunião; } \\
\text { 9. solicitado farmacêutico para o CRS; } \\
\text { 10. agentes do PACS deveriam orientar aos } \\
\text { idosos para, em qualquer problema, passar } \\
\text { pelo médico, em tempo; } \\
\text { 11. sala de micro-cirurgias e suturas não } \\
\text { seria transferida para outra Unidade de } \\
\text { Saúde, por falta de espaço no CRS, mas que } \\
\text { ficasse sob o comando de um médico } \\
\text { cirurgião que só vai fazer isto; } \\
\text { 12. os agentes do PACS devem estar } \\
\text { uniformizados e com crachá para a } \\
\text { população reconhecer melhor e ficar }\end{array}$ & reformas. \\
\hline
\end{tabular}




\begin{tabular}{|c|c|c|}
\hline & & $\begin{array}{l}\text { atenta; } \\
\text { 13. os agentes do PACS devem marcar } \\
\text { somente } 2 \text { consultas por dia. } \\
\text { 14. Oficio pedindo reforço médico pelo } \\
\text { grande numero de pacientes que procuram } \\
\text { a Unidade no diurno. }\end{array}$ \\
\hline
\end{tabular}




\section{CONQUISTAS/AVANCOS DO CONSELHO GESTOR DE SAÚdE} DO CENTRO REGIONAL DE SAÚDE “Dr. JOSÉ GERALDO ABUHASSAN" - VILA ALMEIDA/DISTRITO OESTE - 1994/2002

1. Ficou decidido que o Pronto Atendimento fincionaria das 6 às $24 \mathrm{~h}$ - sem agendamento: com 2 CG, 2 pediatras e 1 Ginecologista e em três turnos quando o quadro estivesse completo. $O C G$ e os agentes do PACS deveriam divulgar este serviço;

2. Reforma: ampliações de novas salas e mudanças na recepção;

3. Instalação de aparelho de ultrasson;

4. Pronto Atendimento: atendimento de urgência e emergência em pediatria e clínico geral, além de plantonistas já existentes, das 24 às 6 h. (36 pacientes por 6 h.);

5. e tratamento completo de dentista;

6. Programa da Campanha da Próstata para homens com mais de 50 anos;

7. $3^{\circ}$ horário (17 as 21 h.) de médicos foi graças à reivindicação do CG;

8. Decreto para insalubridade;

9. Em 18/02/00, já estavam informatizadas as farmácias dos CRSs;

10. atendimento de ginecologia direto, com quadro completo e com material descartável;

11. esse CG, foi considerado, pelo Serviço de Controle Social da SESAU, como um dos CG mais atuantes do município de Campo Grande/MS;

12. um administrativo para o ambulatório e o trabalho da direção vem sendo bom;

13. todas as reformas teve a participação do CG;

14. a Unidade tem tido menos reclamações quanto ao dentista;

os agentes de saúde são elogiados pela atuação humanista e não paternalista;

15. convênio com o Hospital Evangélico para plantões e atendimento ambulatorial;

16. Distritos fortalecidos com equipes de Vigilância Sanitária, Vigilância Epidemiológica;

17. enfermeiro para administrar os Programas;

18. central de ambulância com equipamento moderno para emergências e com carros mais adequados; 
19. ampliação da Unidade, agora, com sala de reunião, almoxarifado, novos consultórios, sala para sutura, copa e cozinha;

20. os Programas estavam indo bem;

21. o Médico de família seria implantado onde havia o Programa de Agentes Comunitários de Saúde;

22. foram chamados dois farmacêuticos e estovam aguardando para assumir;

23. o mutirão de saúde, esporte e lazer, realizado pelos agentes de saúde, sempre tem a parceria da população dos bairros;

24. o CG sempre é chamado a participar no dia da vacinação;

25. a campanha nacional para cães e gatos tem boa divulgação pela imprensa. Campanhas nas creches e campanhas nacional de vacinação e Hanseníase se faz com equipe especializada;

26. concurso público para sanar as dificuldades de estrutura e atendimento básico;

27. Programa da Hipertensão Arterial está presente no CRS do V. Almeida desde 1999, de maneira mais sistematizada;

28. o novo gerente é sensível às reclamações e sugestões colocadas na caixinha e se propõe a entrar em contato com as cartas que tem endereço;

29. uma Rádio FM se colocou à disposição do CRS porque o novo gerente foi fazer a solicitação;

30. a Pastoral da Criança é parceira em vários Programas da Unidade, principalmente no Programa do Desnutrido;

31. Festival de Musical com o tema ERRADICAÇAO DO MOSQUITO DA DENGUE, estimulando a criatividade e prêmios para os vencedores;

32. os conselheiros são comunicados que houve aumento da produtividade em $50 \%$;

33. encontro de conselheiros na Escola de Saúde Pública do estado do Mato Grosso do Sul: planejamento para 1998, feito em 07/97 (citação dos problemas mais comuns: falta de vagas para Clínico e Pediatras; dificuldades para exames de Raios $X$, mamografia, endoscopia e falta de recursos humanos para a Unidade. Citaram as

\footnotetext{
' Neste dia a população também participava de atividades outras promovidas pela Unidade com apoio do Distrito envolvendo jogos, gincana, concurso de frases e poesia, dentre outros
} 
causas dos problemas e propostas de ações que pudessem amenizar as dificuldades);

34. O Prefeito vem dando abertura para $C G$;

35. Está registrado, em meados de 2002, um elogio sobre o andamento e organização da reunião com participação ativa dos usuários. A participação social é muito importante (...); está havendo trabalho conjunto do gestor e da população com avanço e ganhos para a própria população (ATAS-QUESTIONÁRIO).

\section{Posto esses fatos, posso caracterizar este CG da seguinte forma:}

Iniciou suas atividades em 25/02/1994; $2^{a}$ reunião com o Diretor Executivo e lideranças comunitárias vizinhas ao CRS; as reuniões, no inicio, eram marcadas mais ou menos de 15 em 15 dias, conforme calendário a ser elaborado pelo Grupo Gestor; Periodicidade mais estável nos anos 1998-2001; Ano de 1995 muito instável; três paralizações e algumas pausas; Ano de 2002 com dinâmica de reuniões instóveis; Paridade nas 4 eleições: 4:2:2; Representatividade: líderes comunitários, associações de moradores, catequista, gerente do Distrito Sanitário, Pastoral da Saúde e da Criança, agentes de saúde da FUNASA, agentes de saúde comunitários (PACS) e, vez ou outra, acadêmicos de enfermagem da UFMS; As reuniões eram feitas na capela de uma igreja católica e, à partir de 2001, as reuniões passaram a ser feitas na sala de reuniões do CRS; a coordenação do CG sempre foi de conselheiro usuário; a figura da(o) gerente da Unidade é sempre percebida nas Atas; o Presidente da Associação de moradores não é uma figura atuante nas reuniões; o segmento trabalhadores de saúde da Unidade é formado pelo corpo de enfermagem; os conselheiros são, com certa freqüência, substituídos; o CG conformou-se, inicialmente, mais em um cenário de transmissão de informações e espaço para "palpitações"; a partir de 2001, tem-se maior número de situações conflitantes e manifestações de poder dos segmentos; As questões de poder são aparentes. Seguidamente, existe enfrentamento, nas reuniões do $C G$, entre o segmento usuários e prestadores. Neste $C G$, não percebi a reclamação de pouca participação da população e chamado para as novas lideranças; aparece, também, o desejo de garantir o poder das decisões pelo Distrito, ficando a chefe do CRS numa postura mais de observação dos movimentos e encaminhamentos oriundos das decisões; nas reuniões, os conselheiros usuários e os agentes de saúde pouco se posicionam. Na 
reunião assistida houve somente uma deliberação pelo $\mathrm{CG}$ e, esta, com um poder decisório significativo do segmento usuários. Algumas frases retiradas das Atas apontam para esta situação de poder: resistência entre Conselho e funcionalismo (...), alguns conselheiros parecem que querem intimidar funcionários (...), Distrito põe e tira funcionários enfermeiros sem comunicar (...), mostrar, não esconder, onde é o lugar de lutar.

Acredito que este enfrentamento se faça pela própria lógica do andamento dos serviços desta Unidade, anteriormente à paralização do CG, muito voltado para o conforto dos trabalhadores e descaso dos usuários, de acordo com depoimentos de funcionários, durante o periodo deste estudo e até em momentos anteriores, quando de minha atuação nos estágios de saúde coletiva, no curso de Medicina da UFMS. Os vetores de poder nas decisões ficaram mais equilibrados entre estes segmentos, na minha perspectiva, mesmo porque tais conflitos vêm contribuindo para uma busca de consenso com maior envolvimento dos conselheiros, conformando um cenário de maior necessidade de negociação. Fica mais evidente nas Atas e nas entrevistas, o enfrentamento de conflitos, gerando mais decisões e menos aconselhamentos, palpites. $\mathrm{E}$ isto é positivo, em se tratando de gestão participativa!

A situação epidemiológica aponta para questões de saneamento - águas servidas, destino do lixo, água tratada, drenagem de ruas, fossa. Ainda, animais domésticos no CRS, higienização do Canil do município, campanhas de vacinação, prevenção da Dengue e Hanseníase e falta de higiene com as máscaras de inalação. As questões da saúde e da doença estão na dependência dos serviços de saúde, muito embora haja uma preocupação com a prevenção e insistência com as questões de saneamento básico.

Serviços de saúde é a categoria mais presente nos debates, pois falam arduamente da organização e infra-estrutura dos serviços, Programas, equipamentos, papéis diferenciados da urgência/emergência e do ambulatório, escala e produtividade dos médicos, agressão dos usuários, funcionários abordados na recepção de forma agressiva, pouca atenção dos servidores e usos da ambulância. Apontam facilmente os problemas e indicam as necessidades dos usuários e, embora se fale de Programação, ela não está 
explicitada e dirigida para as necessidades, mas se convive com uma rotina construída em cima da "média de tipos de atendimentos", dos conhecimentos empíricos dos procedimentos cotidianos.

Quanto ao setor saúde, vê-se articulação com Hospital Evangélico, para plantões, Pastoral da criança, Vigilância Epidemiológica e Sanitária, mídia, setores da SESAU, preocupações em se difundir a função e finalidade do CG na comunidade, encontros, substituição e capacitação de conselheiros, participação do CG no Conselho Municipal de Saúde, Planejamento anual das atividades, segurança do CRS, recursos sempre muito comprometidos e fiscalização e administração dos $11 \%$ do financiamento.

Estes aspectos indicam que o CG está muito preocupado, de acordo com os elementos de diagnóstico de TESTA, com a categoria Serviços de Saúde e com ênfase na modalidade Administrativo.

Considerando os objetivos deste estudo, importa agora evidenciar quanto e como estas demandas influenciaram as políticas sanitárias no município de Campo Grande-MS, desde o inicio do funcionamento deste $C G$, transpondo as decisões/ deliberações/encaminhamentos para o modelo do ILPES/CLAPS (1975), na busca do tipo de componente decisório presente.

QUADRO 09 - Classificação das decisões/deliberações do Conselho Gestor de Saúde do CRS "Dr. José Gilberto Abuhassan" - V. Almeida - Distrito Oeste Campo Grande/M.S - 1994/2002 segundo ILPES/CLAPS (1975)

\begin{tabular}{|l|c|c|}
\hline CATEGORIA & \multicolumn{1}{|c|}{ ELEMENTO } & $\%$ \\
\hline Nivel Político & $\begin{array}{l}\text { Em setembro de } 2002 \text { foi deliberado que a sala de micro- } \\
\text { cirurgias e suturas são fosse transferida para outra Unidade de } \\
\text { Saúde, por falta de espaço no CRS, mas ficava sob o comando } \\
\\
\text { de um médico cirurgião que só ia fazer isto. As negociações no }\end{array}$ & \\
\hline
\end{tabular}




\begin{tabular}{|c|c|}
\hline & $\begin{array}{l}\text { CG não permitiram a mudança. Não se podia perder o que se } \\
\text { conquistou; } \\
\text { O CG solicitou a planta do CRS para documentar pedidos de } \\
\text { ampliação e encaminhamento para SESAU e Prefeito; } \\
\text { Ofício pedindo reforço médico, pelo grande número de } \\
\text { pacientes que procuram a Unidade no diurno; } \\
\text { Conselheiros devem orientar a população para que recebam os } \\
\text { agentes do PACS em suas; } \\
\text { Os injetáveis estão na emergência, pois a farmácia fecha à } \\
\text { noite; } \\
\text { Pedido para funcionários de serviços gerais nos fins de semana, } \\
\text { pois o fluxo é grande, ou horas extras para funcionário; }\end{array}$ \\
\hline $\begin{array}{l}\text { Nivel técnico- } \\
\text { administrativo }\end{array}$ & $\begin{array}{l}\text { O CG aprovou o Programa mutirão de esporte, lazer e saúde do } \\
\text { CRS com atividades de corte de cabelo, teste capilar, vacinas, } \\
\text { orientações e exames de câncer de mama e vídeo de } \\
\text { aleitamento materno; } \\
\text { Conselheiros deviam orientar a população para que recebessem } \\
\text { os agentes em suas casas; } \\
\text { Oficios para bebedouros e vigias; } \\
\text { Oficio para aparelhos que faltam na emergência; } \\
\text { funcionários de serviços gerais nos fins de semana, pois o fluxo } \\
\text { é grande, ou horas extras para funcionários; } \\
\text { colocação de grades divisórias na recepção para melhorar fluxo } \\
\text { de pessoas; } \\
\text { reforma do setor de Odontologia e a construção de sala de } \\
\text { reunião também ficou deliberado; } \\
\text { Oficio solicitando farmacêutico para o CRS; } \\
\text { Os agentes do PACS devem marcar somente } 2 \text { consultas por } \\
\text { dia; }\end{array}$ \\
\hline
\end{tabular}




\begin{tabular}{|c|c|}
\hline & $\begin{array}{l}\text { Deve-se a gerente tirar as reivindicações da ata da reunião do } \\
\text { CG e encaminhar; } \\
\text { A TV e Vídeo deveriam ser solicitados à Receita Federal, como } \\
\text { doação ao CRS para fins educativos e de informação; } \\
\text { ambulância liberada somente para casos de urgência e } \\
\text { emergência e com assinatura do plantonista; } \\
\text { O Planejamento Anual da Unidade vem acontecendo com a } \\
\text { participação do CG. }\end{array}$ \\
\hline $\begin{array}{l}\text { Nível técnico- } \\
\text { operacional }\end{array}$ & $\begin{array}{l}\text { A Vigilância Sanitária se propôs identificar áreas com sujeiras e } \\
\text { detritos na região da grande Santo Amaro, comprovar com } \\
\text { fotos e encaminhar para CG; } \\
\text { Fscalização para verificar normas de higiene de um canil da } \\
\text { região deste CRS e já adequou às exigências; } \\
\text { Orientar sobre agendamentos com especialistas e coleta de } \\
\text { material para exames; } \\
\text { O CG aprova Programa mutirão de esporte, lazer e saúde do } \\
\text { CRS com atividades de corte de cabelo, teste capilar, vacinas, } \\
\text { orientações e exames de câncer de mama e vídeo de } \\
\text { aleitamento materno; } \\
\text { Os agentes do PACS devem orientar aos idosos para, em } \\
\text { qualquer problema, passar pelo médico, em tempo; } \\
\text { Por questões de segurança os agentes do PACS devem estar } \\
\text { uniformizados e com crachá, para a população reconhecer } \\
\text { melhor e ficar atenta; } \\
\text { Foi encaminhado documento oficial recriminando a agressão e } \\
\text { falta de ética pelos servidores da SESAU, na recepção, quando } \\
\text { em visita ao CRS. }\end{array}$ \\
\hline
\end{tabular}


TABELA 13 - Distribuição numérica dos tipos de decisões tomadas pelo Conselho Gestor - V. Almeida - Distrito Oeste - Campo Grande 1994/2002

\begin{tabular}{|c|c|c|}
\hline CATEGORIA & NÚMERO & $\%$ \\
\hline Nível Politico & 6 & 24 \\
\hline Nivel Técnico-Administrativo & 12 & 48 \\
\hline Nivel técnico-Operacional & 7 & 28 \\
\hline TOTAL & 25 & 100 \\
\hline
\end{tabular}

Fonte: Atas das reuniões 


\subsection{CONSELHO GESTOR DE SAÚDE DO CENTRO DE ESPECIALIDADES MÉDICAS DE CAMPO GRANDE/MS}

$-C E M-1999 / 2002$ 
O CG do Centro de Especialidades Médicas de Campo Grande/MS (CEM) teve sua primeira reunião em 14/09/99 quando realizaram a primeira eleição, com 22 presentes. A área de abrangência desta Unidade é toda a cidade de Campo Grande e, pelo princípio da universalidade, atende uma demanda de 76 municípios. Hoje, $30 \%$ dos clientes, são encaminhamentos das cidades do interior do estado de Mato Grosso do Sul. Trata-se de um grande ambulatório de referência de especialidades e local de realização de exames de média complexidade. Atende urgência, somente, em ortopedia. Para os atendimentos de usuários, de outras cidades, exige-se que passe por uma UBS de Campo Grande.

As Unidades de Saúde têm acesso on line para agendamento das consultas e exames, quando o sistema fica disponivel. Como pode se perceber nos registros anteriores, a questão do agendamento para consultas, no CEM, sempre gerou muita polêmica nas Unidades e, a pedido do CMS, estão terminando um estudo para padronizar os agendamentos a partir de 2003.

\subsection{A ASPECTOS DO FUNCIONAMENTO DO CONSELHO GESTOR DO CENTRO DE ESPECIALIDADES MÉDICAS - CEM -} $1999-2002$

\subsection{A.1 PERIODICIDADE DAS REUNIÕES}

Em 1999, aconteceram 6 reuniões, das quais, 2, sem quorum (novembro e dezembro), com periodicidade de 14 a 28 dias. $\mathrm{O}$ ano de 2000 , iniciou com uma reunião, e foi a única, em 28/02, sem quorum, tendo-se, então, um intervalo de 120 dias de pausa até aí (nov./99 a fev./00). Portanto, sem reuniões em 2000, acontecendo a próxima somente em 07/02/01, aconteceu uma paralisação de 17 meses! No decurso de 2001, aconteceram 7 reuniões, com nova paralisação em agosto, voltando as reuniões em 29/01/2002, mais 5 meses de paralisação. $O$ ano de 2002, mostra maior sistematização nos periodos, havendo 10 reuniões, 4 das quais, sem quorum, nos meses de abril, maio, junho e dezembro. 
TABELA 14 - Periodicidade das reuniões do Conselho Gestor de Saúde do CEM Campo Grande/M.S - 1999/2002

\begin{tabular}{|l|l|l|l|l|l|l|}
\hline ANO & $\begin{array}{l}\mathrm{N}^{\circ} \\
\text { REUNI } \\
\text { OES }\end{array}$ & $\begin{array}{l}\text { Médla de } \\
n^{\circ} \\
\text { presentes }\end{array}$ & PERIODICIDADE & PARALIZAÇŌES & $\begin{array}{l}\text { Data -eleição } \\
\text { PARIDADE }\end{array}$ & COORDENADOR (A) \\
\hline 1999 & 6 & $11^{*}$ & $14-28$ dias & 2 meses & $14 / 94: 3: 3$ & usuário \\
\hline 2000 & 1 & & 12 meses & & \\
\hline 2001 & 7 & $16^{* *}$ & $20-50$ dias & 5 meses & $27 / 34: 2: 2$ & trabalhador \\
\hline 2002 & 10 & 16 & $4-35$ dias & & $8: 4: 4$ & $\begin{array}{l}\text { Trabalhador } \\
\text { substituido por } \\
\text { Prestadora }\end{array}$ \\
\hline
\end{tabular}

FONTE: Atas das reuniões

* constavam assinaturas de presentes em apenas uma das reuniões desse ano.

** nesse ano, assinaturas em três reuniões.

\subsection{A.2 COMPOSIÇÃO DO CONSELHO GESTOR}

A composição desse $C G$ se fez, na primeira vez, sem paridade - 4:3:3. Seguiu-se nova composição com paridade 4:2:2 e, a partir de 2002, conta com 16 conselheiros: 8:4:4

\subsection{A.3 - REPRESENTATIVIDADE - ATORES}

A representação se dá através de representantes de usuários de Unidades de Saúde do município de Campo Grande, trabalhadores do CEM, e prestadores - diretora e vicediretora, Secretária de Saúde do Municipio e o Diretor Executivo da SESAU. O elemento motivador para a participação no CG é buscar melhorias para usuários, participação e esforço, uso constante da Unidade. Todos conheciam o Regimento Interno. Dois conselheiros afirmaram que as decisões são tomadas de comum acordo, um afirmova serem tomadas pelos usuários afirmando, ainda, que os usuários estão mais unidos e mais articulados (ATAS).

Numa das reuniões, sem quorum, com as presenças de trabalhadores e representantes dos usuários, para dar posse a novos conselheiros, não se fez presente o coordenador 
nem a diretora do CEM. Dos conselheiros efetivos, faltaram quase todos. Uma usuária afirmava que falta de representatividade é sério.

\subsection{B - DINÂMICA DO FUNCIONAMENTO DO CONSELHO GESTOR: a prática de atuação do Conselho}

Organizado o CG na primeira reunião, houve um intervalo de um mês. $\mathrm{Na} 2^{\mathrm{a}}$ reunião, não tinha pauta e o coordenador do CG não compareceu. Ele deveria entrar em contato com os conselheiros para saber as sugestões desta reunião. $\mathrm{Na} 3^{\mathrm{a}}$ reunião, a diretora do CEM pediu que se fizesse uma pauta para se saber o que se iria discutir. Normalmente, a pauta era construída antes do início da reunião. Foi um grande desencontro o início, pois o coordenador esteve ausente logo na primeira reunião em que ele deveria conduzir (ATAS).

As figuras de maior expressão, no início, foram a Diretora do CEM e alguns trabalhadores de saúde. O funcionamento do CG do CEM é regulamentado pelo mesmo Regimento das Unidades de Saúde - UBS e CRS.

\section{QUEIXAS DO CONSELHO GESTOR DE SAÚDE DO CENTRO DE ESPECIALIDADES MÉDICAS - CEM - 1999/2002}

\section{SERVIÇOS DE SAÚDE}

Dificuldades de agendamento de endócrino, tinha como explicação que a demanda ultrapassava a capacidade diária de atendimento. Essa questão estaria sendo levada ao CMS. Reclamavam do número escasso de profissionais e o usuário não sabe cobrar, quer solução imediata do problema. Não há médicos que se candidatem ao serviço e a Lei de responsabilidade fiscal limita contratações. As vagas de retorno estavam sendo usadas, indevidamente, por funcionários dos Centros de Saúde, causando grandes transtornos aos pacientes. Reclamavam do mau atendimento de alguns servidores, da 
mureta do piso superior, pois oferecia riscos para as crianças, poucos funcionários na fila dos guichês e falta de cumprimento de horário de ortopedia (ATAS).

Muito embora, apontem como pontos positivos, saber ouvir a comunidade e responder às solicitações dos usuários e funcionários, têm-se dificuldades dos trabalhadores em participar das reuniões, por falta de funcionários, ficando, muitas vezes, impossivel o deslocamento para as reuniões.

\section{SETOR SAÚDE}

Um usuário dizia que já se passavam 30 dias e, ainda, não se tinha feito nenhuma reivindicação. Conselheiro usuário, que foi eleito coordenador, na primeira reunião, em 1997, faltou na segunda reunião. Posteriormente, esse coordenador brigou com o motorista da SESAU. Foi substituído. Este conselheiro ex-coordenador $\left(1^{\circ}\right.$ coordenador), dava ordens aos funcionários, dizendo ser amigo do prefeito, e dizia estar no CG para fiscalizar, e sentia-se acuado devido a toda essa polemica: um idoso estava sem atendimento; ele foi para a fila ajudá-lo, e a funcionária lhe xingou e, ıntão, 2 funcionários o levaram até à gerência. Uma conselheira the orientou: trabalho com idosos há cinco anos, vejo coisas erradas e levo ao Fórum dos Usuários para discussão ou à SESAU. Um conselheiro do Fórum dos Usuários disse que o conselheiro usuário não tem o papel de ficar instruindo, fazendo papel paternalista. O usuário está exigindo mais da qualidade de serviço e os representantes devem lutar por uma politica em conjunto com os gestores. É sério o papel do representante (ATAS).

$\mathrm{O}$ coordenador do $\mathrm{CG}$ do $\mathrm{CEM}$ estava insatisfeito em relação às dificuldades no andamento dos trabalhos, e colocou o cargo à disposição em 16/04/02. Muitos conselheiros titulares nunca participaram (ATA, 29/01/02).

\section{SUGESTÕES REGISTRADAS NAS ATAS DO CONSELHO GESTOR DE SAÚDE DO CENTRO DE ESPECIALIDADES MÉDICAS - CEM 1999/2002}




\section{SERVIÇOS DE SAÚDE}

Pediam treinamento de funcionários para atendimento ao público para somar forças num trabalho com as UBS, partindo para a humanização do SUS, através de curso de humanização e acolhimento (para 2002) (ATAS).

Os médicos pediam para contratar mais cardiologistas, endócrino, neuro, reumato, urologista, oftalmo e ultrassonologista. As propostas seriam avaliadas em 60 dias, pela diretora do CEM - 4 diretores distritais, I representante do Fórum dos Usuários e I do Fórum dos Trabalhadores. Solicitavam mais atendentes na informação e demais guichês, via CG, à SESAU e, também, divulgar aos usuários os serviços conveniados do SUS (ATAS-QUESTIONÁRIO).

Conselheiros deveriam ir ao CPD impedir acesso dos funcionários para consultas de retorno e os médicos precisavam preencher os formulários de encaminhamentos de maneira adequada, sem faltar dados (ATAS).

Foi dito da necessidade de união para a campanha em prol dos ostomizados para que eles tenham o direito de receberas bolsas de colostomia (ATAS).

Agenda aberta não se pode aceitar, pois aumenta o número de faltosos pela distância existente da consulta. Muitos pacientes esquecem ou já resolveu de outra maneira. Existem especialidades com 50,60, 70 e até $100 \%$ de faltosos. É preciso orientar aos usuários desmarcar, caso não venham. Deveriam levantar os faltosos em consultas e exames. Esta questão, hoje, é tema de monografia de especialização da diretora do CEM. As UBS deviam, também, enviar, mensalmente, relação de faltosos ao CG das Unidades. Os usuários precisavam ser orientados quanto ao preparo de exames.

\section{SETOR SAÚDE}

O coordenador deveria ter tempo disponivel, participação ativa e bom relacionamento com todos os segmentos. Diziam os conselheiros que era necessária maior participação dos funcionários e melhor entrosamento entre os conselheiros - a participação efetiva dos membros do CG do CEM. Sentiam a necessidade de 
treinamento para humanizar as relações entre profissionais e usuários. É importante o CG trabalhar junto com os funcionários (ATAS).

A questão do agendamento das Unidades de Saúde para o CEM atravessa estes anos todos com intensas queixas e variadas sugestões. O Fórum Estadual de Usuários sugeriam: 1) agendamento on line e aberto durante todo dia, 2) agendamento sem limite de data e consultas por especialidade, 3) personalizar os pacientes já diagnosticados e/ou com procedimentos cirúrgicos e, 4) que o atendimento ambulatorial não fosse limitado a 16 pacientes. Os conselheiros do CEM sugeriam, dentro do limite de 16 atendimentos, agendar 6 para a primeira consulta, 6, para retornos e, 4, para casos especiais. Esta questão é alvo de estudo com a participação de todas as Unidades de Saúde junto ao CMS para se padronizar esta questão (ATAS).

Têm-se demais sugestões, tais como: confeccionar boletins informativos sobre o CG, esclarecimento sobre o funcionamento do CEM, dar cópia do Regimento aos conselheiros, o coordenador precisava encaminhar a pauta com antecedência, $C G$ elaborar documento para implantar pós-consulta no CEM e nas Unidades, que o Fórum de Usuários encaminhasse, ao CG do CEM, usuários dos Programas do CEM, aviso no mural,para os dias de reuniões do $C G$, que os conselheiros fossem apresentados aos funcionários do CEM e inteirados quanto ao seu funcionamento (ATAS).

O coordenador trabalhador de saúde dizia para não se fazer nenhuma solicitação paralela à SESAU. Devia-se, antes, passar pela gerência do CEM. A Santa Casa precisava divulgar mais as atividades educativas nos Programas, conselheiros de outras Unidades deveriam ser convidados para participar das reuniões do CG do CEM $\mathrm{e}$, ainda, convidar usuários reclamantes para assistir as reuniões. Tudo o que fosse levantado deveria ser deliberado e registrado (ATAS).

Considerando que os usuários sempre têm muitas dúvidas sobre o atendimento, um conselheiro, coordenador do CRS do bairro Coronel Antonino, explicava como poderse-ia resolver esta questão: como a SESAU não pode fazer cartas-respostas para todos, 
pode-se fazer boletim informativo que apresente respostas, de forma geral,das dúvidas mais incidentes e isto poderia interessar aos usuários (observação de reunião). 
QUADRO 10 - ENCAMINHAMENTOS/DELIBERAÇÕES DO CONSELHO GESTOR DE SAÚDE DO CENTRO DE ESPECIALIDADES MÉDICAS - CEM 1999/2002

\begin{tabular}{|c|c|}
\hline & \\
\hline $\begin{array}{l}\text { 1. formas de agendamento: deve ser feito na UBS e aguardar carta } \\
\text { pelo correio e on line para as Unidades conectadas na rede, } \\
\text { acessando, via Sistema Hygea. Há possibilidade de agendamento, } \\
\text { na hora, para especialidade que tem médicos no CEM ou se } \\
\text { sobram vagas. Para retorno, o agendamento é somente no CEM e } \\
\text { encaixe é só para urgência; } \\
\text { 2. sugestões sobre agendamento de especialidades, foram } \\
\left.\text { encaminhadas para o CMS (CI } N^{\circ} 01 / 03 \text { - } 29 / 01 / 03\right) \text {; } \\
\text { 3. apresentada aos usuários a relação dos médicos com os seus } \\
\text { respectivos horários de atendimento; } \\
\text { 4. levantamentos para identificar a origem dos faltosos para se } \\
\text { fazer um trabalho com a comunidade, identificando os motivos que } \\
\text { levaram às faltas. Quem fará a pesquisa serão os conselheiros e os } \\
\text { agentes do PACS; } \\
\text { 5. os usuários de outras localidades, deverão identificar qual a } \\
\text { procedência do encaminhamento? Qual UBS agendou a consulta? } \\
\text { 6. o CEM enviaria documento com número de faltosos para cada }\end{array}$ & $\begin{array}{l}\text { 1. escolha do coordenador e elaboração do calendário de reuniões; } \\
\text { 2. não vamos nos deter com detalhes, os casos que forem surgindo } \\
\text { serão discutidos. Em primeiro lugar, devemos trabalhar a } \\
\text { integração, a definição de papéis de nosso grupo, ler e estudar } \\
\text { sobre o CG; } \\
\text { 3. escolhida uma pessoa para compor a caravana do encontro em } \\
\text { Brasilia para discussão de questões dos recursos da saúde: aumento } \\
\text { do teto do SUS para estados e municipios e aumento da tabela de } \\
\text { procedimentos; } \\
\text { 4. troca do dia e horário das reuniões; } \\
\text { 5. funcionários que quisessem participar das reuniões do CG, } \\
\text { teriam dispensa, sem prejuizo de suas freqüências e remunerações } \\
\text { para se ter mais frequiência no CG; } \\
\text { 6. as caixas de sugestões seriam colocadas na entrada do CEM e } \\
\text { abertas, sempre, às } \sigma^{a} \text { feiras: + urnas com cadeado e formulário } \\
\text { com caneta, à disposição das pessoas; } \\
\text { 7. providências quanto aos passes, para participação mais efetiva }\end{array}$ \\
\hline
\end{tabular}




\begin{tabular}{|c|c|}
\hline $\begin{array}{l}\text { especialidade ao Fórum dos Usuários. } \\
\text { 7. votada pauta sobre aquisição dos veiculos Kombi e ambulância } \\
\text { para serviços de epidemiologia e agilização do transporte das } \\
\text { emergências. } \\
\text { 8. Oficio para a SESAU colocar tela na totalidade da mureta do } \\
\text { piso superior; } \\
\text { 9. Quanto à sugestão do número de consultas, serão abertas } 20 \\
\text { vagas, das quais, } 4 \text { para retorno e não se fará encaixe. }\end{array}$ & $\begin{array}{l}\text { nas reuniões; } \\
\text { 8. Fórum dos Usuários comunicava substituição de conselheiros.; } \\
\text { 9. Oficio encaminhado ao coordenador do FUSUS, reiterando a } \\
\text { lista de faltas nas reuniões do CG, segmento usuários, e solicitando } \\
\text { um posicionamento por parte do Fórum, para atender às } \\
\text { necessidades de funcionamento do CG do CEM; } \\
\text { 10. Oficios ao Fórum dos Usuários, pedindo substituição dos } \\
\text { representantes que não comparecem e solicitando encaminhamento } \\
\text { para a proposta do CG do CEM: que os usuários do CG do CEM } \\
\text { sejam dos Programas sistemáticos e que os conselheiros do CG, do } \\
\text { CEM, tenham uma carteira de identificação; } \\
\text { 11. O controle Social da SESAU faria os crachás de identificação } \\
\text { para os conselheiros; } \\
\text { 12. Oficio para divulgar as reuniões desse CG para outros } \\
\text { Conselhos estarem participando; } \\
\text { 13. urgência em discutir o Regimento para discutir mudanças; já } \\
\text { está em discussão; } \\
\text { 14. enviados } 2 \text { usuários, } 1 \text { trabalhador e } 1 \text { prestador para a } 3^{a} \\
\text { Plenária Municipal de Conselhos em agosto/02. }\end{array}$ \\
\hline
\end{tabular}




\section{CONQUISTAS/AVANÇOS DO CONSELHO GESTOR DE SAÚDE DO CEM - 1999/2002}

1. Mais conscientização dos usuários e melhoria da qualidade do atendimento;

2. auxiliar os diretores e gerentes das Unidades de Saúde a conquistar as melhorias no atendimento;

3. o Fórum dos Usuários representam mais ou menos 1.300 entidades (22/05/01);

4. FUSUS, hoje, desmembrado em Fórum dos Usuários estadual e municipal, são espaços para a participação, lugar onde podemos buscar apoio aos nossos anseios e conquistar nossos direitos e reconhecendo nossos deveres de cidadão;

5. Quanto à dinâmica de funcionamento, afirmam ter melhorado, desde o início, pois adquiriram mais experiência e maturidade. Defendem valores como união, harmonia e compreensão (ATAS-QUESTIONÁRIO).

\section{Posto esses fatos, posso caracterizar este CG da seguinte forma:}

CG criado há 3 anos e três meses (até dez./02); com pausas: 2 meses em 1999; pausa durante todo o ano de 2000 e 5 meses em 2002; com dinâmica mais estável a partir de 2002; composição alterada: 4:3:3 para 4:2: e 8:4:4; sua dinâmica se dá através das reuniões, agendadas através de calendário pré-estabelecido e dirigidas pelo(a) coordenador(a) do Conselho; normalmente, não existe pauta pré-divulgada. As questões são indicadas no início das reuniões pelos conselheiros. As discussões originam reivindicações, sugestões e encaminhamentos, normalmente, ao CMS; as questões levantadas são necessidades sentidas na rotina do atendimento do CEM e, outras, são trazidas pelos conselheiros dos CRS e do Fórum dos Usuários do SUS (FUSUS); esse CG experimentou alguns enfrentamentos com um usuário, escolhido como primeiro coordenador, mas que não assumiu realmente sua função e que ainda se mantém como conselheiro, fazendo ameaças e intimidando alguns funcionários e conselheiros; As decisões e encaminhamentos ficam no aguardo das decisões de níveis hierárquicos superiores - CMS e SESAU; vem sendo solicitada a presença de conselheiros de todas as Unidades de Saúde para o fortalecimento das discussões e facilidade para identificar as problemáticas e as alternativas necessárias; as prioridades deste CG são a conquista 
de maior numero de profissionais em algumas especialidades e, aquisição de veículos $e$ ambulância para melhor atender a população; as questões de poder são aparentes. Pede-se a participação de funcionários e conselheiros de outras Unidades. $\mathrm{O}$ vetor de poder nas decisões dos prestadores de serviços é superior ao dos trabalhadores e usuários, embora os encaminhamentos ganhem o aval destes segmentos, legitimando as decisões. Acredito, de acordo com conversa com a diretora do CEM, que os prestadores estão interessados nas alternativas apresentadas pelos usuários, apesar de traços fortes de desânimo da atual coordenação do CG. Pela precocidade do funcionamento deste CG, e pausa de um ano, em 2000, as discussões e debates ainda estão muito superficiais, assumem uma roupagem mais de aconselhamento e sugestão. Entretanto, é bem claro que em toda reunião precisa haver deliberação.

As demandas, de acordo com a síntese de Diagnóstico de Testa, objetivamente, voltamse para:

Situação epidemiológica: percebo o processo saúde-doença discutido e acompanhado, enfaticamente, na perspectiva da assistência que exige tecnologia de média complexidade. Mas é compreensível, pois se trata de um grande ambulatório de referência para especialidades e exames não somente para o município, mas, considerando a universalidade do SUS, para todo o estado de Mato Grosso do Sul, dada a uma atenção de quase ausência desses procedimentos em muitas cidades do interior. Há intensa demanda reprimida e as questões de agendamento pelas Unidades, de há muito, têm trazido grande insatisfação para todos os segmentos dos CG do CEM, e de todas as Unidades de Saúde de Campo Grande - atuando como um "corpo de bombeiros". É lembrada e se percebe interesse pela divulgação de ações educativas pela Santa Casa.

Serviços de saúde é a categoria fortemente presente. Discutem, enfaticamente, as ações e serviços, Programas, horário de atendimento dos médicos. Percebe-se, nitidamente, a busca da eficiência e da eficácia do atendimento na construção de caminhos assistenciais, é claro, pois são ambulatório de especialidades de referência. Queixam-se da fila dos guichês, falta de cumprimento de horário de algumas especialidades; pedem médicos, diversidade de especialidades, facilidade de acesso ao agendamento, 
imediatismo no atendimento, vagas para retorno, qualidade no atendimento, capacitação de equipe de saúde; interesse pela representatividade. Têm como dificuldades encaminhamentos de clientes de outras localidades do estado, veículos para agilizar as atividades da rotina, fila nos guichês, número elevado de faltosos a consultas e exames. Presença de um episódio de luta pelo poder do primeiro coordenador deste $C G$, ao dizer ser amigo do Prefeito e enfrentar trabalhadores em algumas rotinas.

Setor Saúde: pedem a representação de todas as Unidades de Saúde do município para melhor identificarem a realidade das necessidades dos serviços oferecidos, principalmente na questão do agendamento; interesse pela divulgação de ações educativas, desejo de sempre deliberar as questões discutidas; buscam apoio do FUSUS; a importância do CG trabalhar junto com os funcionários, confecção de boletim informativo, demanda reprimida para algumas especialidades, eleição, escolha de coordenador, substituição de conselheiros, calendário de reuniões, plenárias de saúde: Brasilia e Campo Grande, papéis e maior integração entre os conselheiros, participação de funcionários nas reuniões do $\mathrm{CG}$ sem prejuizo de sua freqüência e remunerações; preocupação do coordenador (trabalhador) quanto ao CG mandar solicitações sem conhecimento da direção do CEM, divulgação do CG e funcionamento do CEM, pauta para reuniões feita com antecedência, transporte para conselheiros e discussão do atual Regimento do CG.

Tais aspectos denotam que o CG está voltado, de acordo com os elementos de diagnóstico de TESTA para a categoria Serviços e Setor Saúde e para a modalidade, predominantemente, Administrativo.

Transponho as decisões/deliberações e seus encaminhamentos para o referencial do ILPES/CLAPS/OMS (1975) no intuito de identificar os componentes considerados básicos do processo decisório do Conselho. 
QUADRO 11 - CLASSIFICAÇÃO DAS DECISÕES/ENCAMINHAMENTOS DO CONSELHO DE SAÚDE DO CEM - CAMPO GRANDE/MS - 2002, DE ACORDO COM O REFERENCIAL ILPES/CLAPS (1975)

\begin{tabular}{|c|c|c|}
\hline Categorias & Elementos & $\%$ \\
\hline Nível Político & $\begin{array}{l}\text { abertas } 20 \text { vagas para consultas, dentre elas, } 4 \text { para retorno e não } \\
\text { se fará encaixe; } \\
\text { divulgação das reuniões desse CG para outros; } \\
\text { urgência em discutir o Regimento para discutir mudanças; } \\
\text { Oficios ao Fórum dos Usuários pedindo substituição dos } \\
\text { representantes que não comparecem; } \\
\text { solicitando encaminhamento para a proposta do CG do CEM: } \\
\text { que os usuários do CG do CEM sejam dos Programas } \\
\text { sistemáticos; } \\
\text { encaminhamentos de outras localidades; } \\
\text { participação de trabalhadores do CEM nas reuniões do CG sem } \\
\text { prejuizo de suas freqüências e remunerações; } \\
\text { passes para participação mais efetiva nas reuniões; } \\
\text { trabalhar a integração, definição de papéis do grupo, ler e estudar } \\
\text { sobre CG. }\end{array}$ & 45 \\
\hline $\begin{array}{l}\text { Nível } \\
\text { Técnico- } \\
\text { administrati } \\
\text { vo }\end{array}$ & $\begin{array}{l}\left.\text { agendamento de especialidades (CI } \mathbf{N}^{\circ} 01 / 03-29 / 01 / 03\right) \\
\text { relação dos médicos com seus respectivos horários de } \\
\text { atendimento; } \\
\text { levantamentos para identificar a origem dos faltosos; } \\
\text { enviar documento com número de usuários faltosos para cada } \\
\text { especialidade ao Fórum dos Usuários; } \\
\text { votada pauta sobre aquisição dos veículos Kombi e ambulância } \\
\text { para serviços de epidemiologia e agilização do transporte das } \\
\text { emergências; } \\
\text { Oficio para a SESAU colocar tela na totalidade da mureta do piso }\end{array}$ & 35 \\
\hline
\end{tabular}




\begin{tabular}{|l|l|l|}
\hline & $\begin{array}{l}\text { superior; } \\
\text { troca do dia e horário das reuniões. }\end{array}$ & \\
\hline Nível & $\begin{array}{l}\text { trabalho com a comunidade, identificando os motivos que } \\
\text { Técnico- } \\
\text { operacional }\end{array}$ & $\begin{array}{l}\text { levaram às faltas; } \\
\text { a pesquisa dos faltosos será feita pelos conselheiros e os agentes } \\
\text { do PACS; } \\
\text { caixas de sugestões colocadas na entrada do CEM e abertas } \\
\text { sempre às } 6^{2} \text { feiras: } 4 \text { urnas com cadeado e formulário com caneta } \\
\text { à disposição das pessoas; } \\
\text { crachás de identificação para os conselheiros. }\end{array}$ \\
\hline
\end{tabular}

TOTAL $=100$

TABELA 15 - Distribuição numérica dos tipos de decisões tomadas pelo Conselho Gestor de Saúde do CEM - Campo Grande/M.S 1999/2002

\begin{tabular}{|c|c|c|}
\hline CATEGORIA & NÚMERO & $\%$ \\
\hline Nivel Político & 9 & 45 \\
\hline Nível Técnico-Administrativo & 7 & 35 \\
\hline Nível técnico-Operacional & 4 & 20 \\
\hline TOTAL & 20 & $100 \%$ \\
\hline
\end{tabular}

Fonte: Atas das reuniões 
7. ANÁLISE FINAL CONSELHOS GESTORES DE CENTROS REGIONAIS DE SAÚDE 
O conceito de participação vem sendo concebido de diferentes formas, considerando-se os diferentes momentos sócio-políticos no Brasil e, de acordo com JACOBI (2000), está permeado de contradições, dado, principalmente, a sua amplitude conceitual: participação popular, participação citadina, participação comunitária, participação social. Mas todas as referências feitas ao processo de participação caracterizam-na como um encontro de classes sociais, trabalhadores e, mais recentemente, entidades representativas exercendo um poder político no aparelho de Estado, de maneira difusa, organizada e institucionalizada, com vistas a intervir e democratizar o processo o processo de gestão da coisa pública manifestando-se, ainda, como um método de governo. Mostra-se como outra forma de poder.

O CES/MS foi criado em jun./91 e o CMS/Campo Grande em dez./90 - mas esse só foi regulamentado e efetivado em ago./91, dois meses depois de iniciadas as atividades do CES. O processo da criação dos CG de Unidades avançava mas, somente em 1994, surgia o primeiro CG de Unidades chamadas Unidades de Urgência (24 h.).

Foram analisadas, aproximadamente, 335 Atas, assim distribuídas: Vila Almeida: 71; Nova Bahia: 93; Aero Rancho: 45; Moreninha III: 97 e, CEM: 25. Quanto ao grau de organização dos CG estudados podemos perceber alguns aspectos: Cada CRS tem, na sua área de abrangência, um conjunto muito grande de bairros, mas a representação tornar presente - destes bairros nos CG é pouco expressiva, haja vista a presença de poucos líderes das associações de moradores. Somam-se a estes líderes, clubes de mães, pastoral, poucos usuários, alguns trabalhadores mais interessados das Unidades. Nas palavras de BARROS (s.d.),

representação significa delegação de poderes conferidos pela população a certas pessoas a fim de que exerçam em seu nome alguma função. (...) Só serão representantes legitimos se forem escolhidos e indicados pelos membros do grupo ou da entidade da qual fazem parte.

Por conta da reduzida representação dos bairros, fica comprometida a legitimidade deste CG, pois a representatividade - representar interesses dos grupos - não vem sendo 
contemplada na sua magnitude. Em algumas situações o conselheiro pouco contribui pois não está, efetivamente, falando em nome de seu grupo ou entidade e, por não deter as informações necessárias de sua base, compromete a eficácia das decisões.

Nos estudos de WESTPHAL (1992, p. 90-93),

\begin{abstract}
boa parte dos representantes, aliás, vem dos movimentos populares, o que lhes garante uma representação qualitativamente diferenciada pelo acúmulo de discussão. Porém, onde a organização popular não existe, as dificuldades aumentam pela ausência de uma política clara de representação (...).(...) A falta de uma politica de representação reflete em grande medida um caráter de ensaio e erro. (..). a maioria dos usuários que, como se sabe bem, não estão organizados.
\end{abstract}

A questão da representatividade se apresenta ainda em fator limitante, pois os conselheiros comparecem aos órgãos sem consultar suas bases, "não se realimentando da ideologia e da visão de grupo a respeito dos problemas". Suas falas nem sempre indicam os interesses, encaminhamentos e ações desejadas pelos demais cidadãos. Tornam-se alvos fáceis da cooptação e da tutela (idem). Este comportamento denota ausência de liderança, aquela orientada por uma ideologia do grupo que se representa. Aliás, esta representatividade está atrelada ao próprio processo de representação, o que, ainda hoje, também se mostra como fator limitante, pois muitos bairros não são representados nos CG.

Os conselheiros usuários do CEM, na maioria, são conselheiros dos CRS. Há um pedido para que todas as Unidades de Saúde se façam representar nas reuniões do CEM, mesmo que somente com direito a voz, mas ainda não se chegou a esse nível de representação. Os poucos líderes comunitários que atuam diretamente, acreditam que este canal de diálogo e gestão precisa ser trabalhado (entrevista conselheiro usuário). Percebe-se, além desses interesses coletivos, interesses pessoais em atuar como conselheiros do CG; pode-lhes render dividendos políticos - serem candidatos a vereador, vantagens com algum político, dentre outros. Não há um movimento, embora sempre seja solicitado, que assuma a divulgação do CG, seu papel, funções e impacto 
necessário nas questões sanitárias, pois somente os conselheiros não têm alcançado a população.

Quanto ao segmento prestadores de serviços, no início da criação de cada CG, prestadores da SESAU - faziam-se presentes de maneira mais sistemática, devido à necessidade de um certo estímulo e o ensinamento dos "primeiros passos" na participação social neste tipo de Conselho. Da criação dos primeiros CG de Unidades 24 h. (CRS), até a criação do CG do CEM, que é referência para o município se passaram cinco anos.

TABELA 16 - Comparativo entre as datas de criação dos CG dos CRS estudados e do CEM - Campo Grande/M.S - 1994/2002

\begin{tabular}{|c|c|}
\hline CRS & Data de criaçāo \\
\hline Nova Bahia & $12 / 01 / 94$ \\
\hline Aero Rancho & $27 / 09 / 97$ \\
\hline Moreninha III & $01 / 10 / 96$ \\
\hline Vila Almeida & $25 / 02 / 94$ \\
\hline$C E M$ & $09 / 99$ \\
\hline
\end{tabular}

O mandato é de dois anos, podendo ser reconduzido. A composição, nem sempre, conformava-se em paridade, mas há preocupação com este detalhe legal. Em caso de desistência, o substituto era da mesma associação ou se abria vaga para outra entidade, contradizendo o Regimento - devendo ser indicados nomes de entidades diferentes para as vagas de titular e suplente (ATAS). 
TABELA 17 - Composição - por periodo de gestão - dos CG dos CRS estudados e do CEM - Campo Grande/M.S - 1994/2002

\begin{tabular}{|c|c|c|c|c|c|}
\hline Ano & N. Bahìa & Aero Rancho & V. Almeida & Moreninha III & CEM \\
\hline & $\frac{\text { Composiçăo }}{\text { Coordenador(a) }}$ & $\frac{\text { Composição }}{\text { Coordenador(a) }}$ & $\begin{array}{l}\text { Composiçäo } \\
\text { Coordenador(a) }\end{array}$ & $\begin{array}{l}\text { Composição } \\
\text { Coordenador(a) }\end{array}$ & $\begin{array}{l}\text { Composiçăo } \\
\text { Coordenador(a) }\end{array}$ \\
\hline 1994 & $\begin{array}{l}3: 2: 2 \\
\text { USUÁRIO } \\
4: 2: 2\end{array}$ & & $4: 2: 2$ - USUUÁRIO & & \\
\hline 1996 & 4:2:2 - USUÁRIO & & & $4: 2: 2$ - USUARIO & \\
\hline 1997 & & 4:2:2 - USUÁRIO & 4:2:2 - USUÁRIO & & \\
\hline 1998 & 4:2:2 - USUÁRIO & & 4:2:2 - USUÁRIO & 3:4:4 - USUARIO & PRESTADOR \\
\hline 1999 & & & 4:2:2 USUÁRIO & & 4:3:3 - USUÁRIO \\
\hline 2000 & $2: 2: 1$ - USUÁRIO & 4:2:2 - USUARIO & & 4:2:2 - USUÁRIO & \\
\hline 2001 & 4:2:2 USUÁRIO & & & $6: 3: 3-$ & $\begin{array}{l}\text { 4:2:2 } \\
\text { TRABALHADOR }\end{array}$ \\
\hline 2002 & $\begin{array}{l}8: 4: \\
\text { PRESTADOR }\end{array}$ & 8:4:4 - PRESTADOR & & & $\begin{array}{l}8: 4: 4 \quad \text { trabalhador } \\
\text { substituido - prestador }\end{array}$ \\
\hline
\end{tabular}

Fonte: Atas

A escolaridade do segmento prestador é superior, em alguns casos, com pós-graduação lato sensu; a dos trabalhadores, na maioria, é superior e a escolaridade dos usuários varia entre Ensino médio ou Fundamental completo ou incompleto. Os CG, de início, não tiveram os nomes dos conselheiros registrados; processo esse que aconteceu com todos em 23/mar./98. Hoje, todos os nomes, quando de nova eleição são homologados pelo CMS.

A periodicidade das reuniões dos CG estudados revela que, inicialmente, as intenções eram de reuniões mensais, em alguns, quinzenais. No entanto, conformaram-se em reuniões mensais devido a compromissos pessoais dos conselheiros e à maior sistematização do $\mathrm{CG}$, mas aconteceram intercorrências, incluindo pausas de até mais de um ano. Mas um processo social iniciado deixou marcas institucionais influenciando, principalmente, os trabalhadores de saúde a retomarem a dinâmica do funcionamento dos CG. Os dados indicam que os Conselhos, inicialmente, tiveram um maior número 
de reuniões, procurando, com rapidez, a construção da formalidade do Controle Social. Os Conselhos mais antigos tiveram mais e maiores intervalos de pausas, à exceção do CG do CEM, de criação recente e que apresenta algumas particularidades por ser de referência para todo o município. Esse fato pode indicar que os primeiros Conselhos criados não tinham nada de experiência no funcionamento de tais Conselhos. Os mais recentes já foram criados em cima de experiências dos anteriores. Essa informação confirma o caráter de ensaio e erro defendido acima por WESTPHAL.

TABELA 18 - Número de Reuniões e número de presentes nas reuniões dos CG dos CRS estudados e do CEM - Campo Grande/M.S - 1994/2002

\begin{tabular}{|c|c|c|c|c|c|}
\hline ANO & $\begin{array}{l}\mathrm{N}^{\circ} \text { REUNOOES } \\
\mathrm{N}^{\circ} \text { presentes }\end{array}$ & $\begin{array}{l}N^{\circ} \text { REUNIÕES } \\
N^{\circ} \text { presentes }\end{array}$ & $\begin{array}{c}N^{\circ} \text { REUNIÕES } \\
N^{\circ} \text { presentes }\end{array}$ & $\begin{array}{l}N^{\circ} \text { REUNIÕES } \\
N^{\circ} \text { presentes }\end{array}$ & $\begin{array}{c}N^{\circ} \text { REUNIÕES } \\
\mathrm{N}^{0} \text { presentes }\end{array}$ \\
\hline & Almeida & A. Rancho & Moreninha & N. Bahia & CEM \\
\hline 1994 & $5-13.4$ & & & $18-9,7$ & \\
\hline 1995 & $8-\sim 4$ & & & $6-10$ & \\
\hline 1996 & $4-10$ & & $8-13$ & $13-7,6$ & \\
\hline 1997 & $6-7$ & $5-9$ & $15-11$ & $11-7,5$ & \\
\hline 1998 & $9-\sim 7.5$ & $9-\tilde{\text { n }}$ registro & $14-21$ & $10-11,6$ & \\
\hline 1999 & $17-\sim 11.4$ & $11-9$ & $12-12$ & $2-* *$ & $6-11^{*}$ \\
\hline 2000 & $12-\sim 5.8$ & $10-\sim 16.4$ & $14-21$ & $3-* *$ & 1 \\
\hline 2001 & $6-12$ & $3-16$ & $10-21$ & $2-* *$ & $7-16^{*}$ \\
\hline 2002 & $6-\sim 9.6$ & $16-15$ & 6 (até 08/02) - 20 & $15-* * *$ & $10-16$ \\
\hline
\end{tabular}

${ }^{*}$ registro de presentes somente em uma reunião

** PAUSA

*** NÃO ASSINATURAS

De acordo com a REDE IDA o processo de participação social se dá de forma sempre crescente, podendo involuir em certos momentos" (REDE IDA - boletim, 1993, p. 3). Em Campo Grande vê-se este fato nos CG das Unidades de Saúde - CRS e UBS e, nos CG estudados, ocorreram algumas pausas e paralisações. 
QUADRO 12 - Pausas nas Reuniões dos CG dos CRS estudados e do CEM - Campo Grande/M.S - 1994/2002

\begin{tabular}{|c|c|c|c|c|c|}
\hline ANO & PAUSAS & PAUSAS & PAUSAS & PAUSAS & PAUSAS \\
\hline & Almeida & A. Rancho & Moreninha & N. Bahia & CEM \\
\hline 1994 & 5 meses e meio & & & 98 dias & \\
\hline 1995 & $\begin{array}{c}2 \text { sem quorum e } 14 \\
\text { meses e meio }\end{array}$ & & & $\begin{array}{c}90 \text { dias (2 } \\
\text { vezes) }\end{array}$ & \\
\hline 1996 & $\begin{array}{l}1 \text { sem quorum e } 7 \\
\text { meses (até jun./97) }\end{array}$ & & & 2 sem quorum & \\
\hline 1998 & & 9 meses & & 110 dias & \\
\hline 1999 & & 54 dias & & $\begin{array}{c}19 \text { meses - } \\
24 / 02 \text { à } 18 / 7 / 00\end{array}$ & 2 meses \\
\hline 2000 & & 4 meses & & 14 meses & 12 meses \\
\hline 2001 & & 5 meses & 90 dias & & 5 meses \\
\hline 2002 & $\begin{array}{c}\text { Maio - agos } \\
\text { Set. - jan./03 } \\
7 \text { meses }\end{array}$ & & 75 dias & & \\
\hline
\end{tabular}

O Plenário é composto, sempre, por coordenador(a), secretário(a), comissões de trabalho, quando necessário, não há secretaria executiva. A coordenação, inicialmente, de usuário, na maioria das eleições, vem sendo desenvolvida por prestador/trabalhador, na maioria das últimas eleições. Este procedimento parece indicar maiores facilidades para a gestão do CG. O prestador ou trabalhador já está na Unidade, conhece melhor a hierarquia e órgãos afins, tem maior disponibilidade e infra-estrutura para trabalhar; tem mais informações sobre as rotinas e procedimentos e facilidade e agilidade nos acessos a vários órgãos, dentre outros. A secretaria dos CG é responsabilidade de um dos conselheiros, indicada por eles mesmos. Existe uma agenda para a reunião. Às vezes ela vem pronta, às vezes ela se constrói no início da reunião. Mas não é antecipada na forma de pré-agenda para conhecimento dos conselheiros. Não são todos os CG que tem uma pauta de reunião pré-estabelecida. Vão-se discutindo conforme as demandas indicadas no inicio da reunião pelos conselheiros. 
As reuniões são ordinárias, mensalmente, previstas em calendário e, raramente, extraordinárias. O local das reuniões, inicialmente, variou bastante, pois queriam reuniões itinerantes com o intuito de divulgar as atividades do CG. Nos dois últimos anos, as reuniões acontecem na estrutura do CRS.

No Plenário sempre estão presentes agentes do PACS e, raramente, usuários que não são conselheiros, salvo quando de uma reunião com lideranças da Prefeitura ou da SESAU. O tempo médio das reuniões é de uma hora e meia. Faz-se a leitura e aprovação da Ata da reunião anterior, com retificações quando necessário. Na ordem do dia, nem sempre existem deliberações. Somente o CG do CEM votou esta prática "tudo o que for levantado deve ser deliberado e registrado". No $1^{\circ}$ sem/03 os CG estão em estudo para reformulação do RI.

Quanto à prática de atuação os conselheiros têm liberdade para manifestar-se nas discussões; sempre votam - não consta em registro abstenção de votar; propõem comissões de trabalho e quanto às faltas, o Fórum de Usuários é notificado no caso do CEM, o qual indica novo conselheiro.

Têm-se queixas que permanecem por longos períodos. $\mathrm{O}$ que isto pode significar? Há (des)interesse da burocracia para as devidas soluções? Pode-se considerar tais queixas como evento Sentinela. Deve-se atentar para elas sob o risco de agravar a situação. E nessa perspectiva da queixa como Evento Sentinela questiona-se: qual o nível de interesse da burocracia municipal em atender as queixas dos conselheiros? Quais os recursos disponíveis para minimizar tais queixas? Em que lugar do ranque das prioridades programáticas do município tais queixas estão situadas? Quais os critérios da administração da SESAU e do município para priorizar tais queixas?

As rifas são ações que apontam para a irracionalidade da organização dos serviços e os mutirões, para um certo grau de desatenção para o ambiente, principalmente, pela demanda constante da prevenção da dengue. Este tipo de participação (mutirão) é uma participação ativa e deve ter nos serviços públicos a liderança e a responsabilidade para 
resolver o problema do lixo e sensibilizar a população para os cuidados necessários com o ambiente.

As questões de agendamento de consultas e exames sempre estiveram presentes nas discussões dos Conselhos. O processo de agendamento vinha sendo manual, nas UBS e CRS, até 1997. Nas UBS existiam várias situações de agendamento: 3 em 3 dias, sempre aberto, de véspera, com data e horário. Em 1998, a SESAU passou por um período de transição para a informatização da recepção, primeiramente, e de alguns outros setores, nos CRS.

Quanto ao agendamento para o $C E M$ as propostas conformam um histórico:

14/11/97: ficou deliberado que seria de um dia para outro, pois estava há cada 15 dias e os usuários faltavam muito;

10/03/99: pedia-se aprimoramento do agendamento;

12/05/99: ainda se reclamava da forma do agendamento;

09/06/99: propunha-se agendamento permanente;

13/10/99: o agendamento para exames seria on line na Unidade para o Centro de Especialidades Médicas - CEM;

14/06/ e 14/07/00: discutia-se ainda sobre agendamento;

Hoje, a questão do agendamento das Unidades para o $C E M$ está em processo de resolução final. Está em estudo, por todos os CG, a padronização de agendamento do CEM, a ser discutido e homologado pelo CMS.

As demandas e seus desdobramentos, conformam um cenário de diálogo que inclui queixas, sugestões/reivindicações, podendo culminar em tomada de decisão para "o que encaminhar". Estas demandas se inserem nas categorias, de acordo com a sintese de Diagnóstico de TESTA (referido por SÁ, 1986) - roteiro simplificado -, em situação epidemiológica, serviços de saúde e setor saúde e apontam, de acordo com as análises particularizadas de cada Conselho, para um cenário composto, predominantemente, com os elementos administrativos e voltados, com grande ênfase e em ordem decrescente, para os serviços de saúde, setor saúde e situação epidemiológica. No caso do CEM, 
dada a sua particularidade de referência para o município e até para o estado, o elemento fortemente presente nas demandas é Serviço de Saúde. A evidência marcante da categoria Serviço de Saúde mostra a prioridade dada aos conselheiros com a organização dos serviços, a resolutividade da Unidade, a infra-estrutura necessária para os vários procedimentos e ações de saúde, dentre outros.

Os elementos presentes nas categorias são os seguintes:

$\mathrm{Na}$ situação epidemiológica: agentes, vetores, hospedeiros - subentendido na morbidade e mortalidade; algumas condições ambientais: saneamento - água, lixo, lixão, águas servidas; o "social” - quando se referem a grupos como idosos, crianças, gestantes, deixando, algumas vezes implícito, questões sócio-econômicas e situações de risco.

O processo de trabalho dos CG é bem transparente: reuniões ordinárias e extraordinárias com encaminhamentos via Ofícios e/ou visitas a pessoas e/ou instituições. O modo de produção dos usuários dos serviços é dos mais variados, mas predominam processos ligados ao setor secundário e terciário e ligados a variados grupos sociais. Os bairros são servidos de toda infra-estrutura básica de circulação e distribuição de mercadorias, bens ou serviços, excetuando-se serviços bancários. Pelas demandas sempre presentes nas discussões o processo saúde-doença é ainda fortemente percebido na dependência de medicamentos e assistência médica. Fala-se bastante em prevenção e cuidados com o ambiente como elementos necessários a bons níveis de saúde. A questão da promoção da saúde nos serviços de saúde e nos bairros de referência começaram a aparecer em Ata, no final de 2002, no CG do CRS do bairro Nova Bahia na expressão entorno saudóvel.

$\mathrm{O}$ ambiente tem preocupado os conselheiros de todos os $\mathrm{CG}$ estudados. $\mathrm{O}$ problema das queimadas, falta de saneamento, escoamento de águas servidas, supermercados e lavajatos clandestinos têm se mostrado como desafio para os órgãos competentes. A Vigilância Sanitária tem estado em algumas reuniões e comunica que registra com fotos e relatórios a situação de certas áreas, repassam para a SESAU e aguardam a posição a ser tomada. 
Serviços de saúde: eficácia, eficiência, cobertura dos serviços, serviços e Programas desenvolvidos são mensagens, algumas vezes subjetivas, na maioria das reuniões. Quanto aos recursos: organização dos serviços; função, quantidade, distribuição e disponibilidade dos servidores, da produção de atividades e produtividade da Unidade de Saúde mas, principalmente, dos médicos são aspectos que sempre estão no bojo das reivindicações e sugestões.

O poder técnico é bem aparente no CEM. Nos CG dos CRS, o conselheiro trabalhador e usuário tinha, no início da formação dos CG, uma atuação mais evidente. Isto se deve a uma vivência num universo mais próximo às problemáticas discutidas. Mais recentemente, os prestadores de serviços têm assumido, em conjunto com os usuários, a maior fatia nas decisões e encaminhamentos.

Disputas cotidianas sobre o quê fazer e como fazer são, também, aparentes nos CG. O desequilibrio de forças se dá, às vezes, em variadas direções a depender da problemática, mas, na maioria das vezes, em defesa dos direitos dos usuários. Quando os interesses dos usuários demoram a ser atendidos, a credibilidade do Conselho cai e, via de regra, a resposta desse segmento é o esvaziamento do quorum nas reuniões que pode resultar em pausas as quais, de dois anos pra cá, tem sido de, no máximo, 3 a 4 meses. Algumas dessas disputas apontam para interesses particulares de conselheiros que almejam maior reconhecimento de seu trabalho, impor-se melhor como líder de bairro, projetar-se nos Fóruns que se articulam com o setor saúde, ser notado por setores de órgãos públicos, candidatar-se à função de vereador, dentre outros. De dois anos para cá, os conselheiros têm conseguido se articular melhor politicamente em vários níveis dos serviços públicos e privados, contribuindo para melhorar, principalmente, a acessibilidade, a resolutividade e a produtividade médica. Percebe-se, pelas Atas e pela fala dos conselheiros que os três segmentos estão interessados nessa modalidade de gestão participativa, mas o segmento prestador tem estado muito preocupado quando acontece o esvaziamento do $\mathrm{CG}$.

Setor saúde: organização do setor saúde e suas relações com demais entidades do município, visando, com freqüência, as parcerias e a interação, no entendimento de que 
ações de prevenção, assistência e proteção da saúde se constróem na perspectiva da interinstitucionalidade; relações entre os conselheiros e destes com demais entidades do setor saúde ou não com as quais, vez ou outra, eles se relacionam; interdependência de niveis hierárquicos do setor saúde, de Fóruns integrados ao setor saúde, de demais Unidades de Saúde de nível básico, de urgência e/ou de referência, de Plenárias de Saúde, de órgãos afins dos níveis estadual e federal. Percebe-se, mas recentemente, um poder de decisão maior originado no segmento usuário e prestador de serviços. Discutem sobre os recursos que são reduzidos, dificultando a priorização das ações, a atuação dos CG no planejamento do municipio, a qualidade dos atendimentos e das ações prestadas e as relações funcionais entre servidores, servidores-usuários, servidores-conselheiros e Conselho-instituições.

As questões do financiamento para o setor (formas, origem, destinação e controle) são alvos, normalmente, de informações aos conselheiros. Esta questão fica mais com o CMS. O Planejamento para o quadriênio 2002-2005 foi conformado, pelo setor de planejamento da SESAU com encaminhamentos das Unidades de Saúde e debates no CMS através do processo de planejamento ascendente, contribuindo, inclusive, para o fortalecimento de um processo educativo em saúde. De acordo com a Secretária de Saúde (entrevista, 2002), e quanto ao funcionamento dos CG

O movimento cresceu muito, principalmente pelo fortalecimento dos Fórum de Trabalhadores e Usuários de Saúde, mas também pelo trabalho do Serviço de Apoio ao Controle Social - SACS, que adotou a capacitação continuada, instituiu o informativo trimestral e se colocou como verdadeiro apoio para esses colegiados, além do envolvimento dos gerentes de Unidades que, em geral, são os coordenadores dos Conselhos Gestores. Outros fatores também contribuiram, como a inserção do espaço na pauta do Conselho Municipal e, mais recentemente, a elaboração do regimento interno, cujo processo de discussão também se constitui em capacitação. Porém, há um fato que reputo importantissimo: desde maio/98, a SESAU adotou o processo de planejamento ascendente, que se inicia no ambito dos Conselhos Gestores. Em que pese estar mais desenvolvido em algumas Unidades e mais precário em outras, serviu para apontar o papel desses Conselhos e a sua representatividade perante a comunidade usuária da Unidade. Também merece destaque a deliberação do Conselho Municipal no sentido de que os hospitais conveniados com o SUS também organizem 
seus conselhos gestores e a iniciativa dos Distritos Sanitários em criar os Conselhos Distritais. Estes últimos, têm mantido uma articulação (ainda muito tênue) com os Conselhos das Regiões Urbanas [em número de sete no municipio].

A Lei 8080, Art. 36 estabelece o planejamento ascendente, “(...) ouvido seus órgãos deliberativos, compatibilizando-se as necessidades da política de saúde com a disponibilidade de recursos em planos de saúde dos municípios, dos estados, do Distrito Federal e da União" e que, de acordo com Cecilio (1992, p. 69), “(...) poderá ser traduzido em 'elaboração de planos para a programação e captação de recursos financeiros'.

Considerando-se os debates nos CG desde 1994, tem-se, a partir de 2000, maior coerência entre propostas da SESAU, maior interação entre Conselhos e setores da SESAU destinados a acompanhar essa prática social em saúde pública. Mas a percepção dos usuários do SUS quanto aos Conselhos e ao próprio Sistema de Saúde do país, ainda é de pouca credibilidade. A percepção dos conselheiros quanto ao Controle Social vem melhorando pelo contato mais direto com as entidades ligadas aos serviços e instituições do setor saúde.

Muito embora se discuta, defenda-se, deseje-se a mudança do modelo assistencial em Campo Grande já desde os anos 95/96, a lógica do atendimento ainda se dá no modelo biológico agregando-se alguns, mas ainda poucos elementos, do modelo da multicausalidade do processo saúde-doença. E essa percepção permeia os debates nos Conselhos.

Vale a pena destacar que as Oficinas de capacitação vêm abordando as temáticas processo saúde-doença, princípios do SUS, Controle Social, Regimento, papel dos conselheiros. Os conselheiros, hoje,

já têm mais claro seu papel, pois no inicio, sentiam-se com o poder de controlar, por exemplo, presença e livro ponto dos funcionários. As Plenárias de Saúde vêm contribuindo para troca de experiências entre os CG da capital, estimulo à organização dos CG e maior participação nos variados fóruns do municipio 
Necessitam de mais vivência e capacitação continuada (setor de controle social da SESAU)

As decisões são formalizadas em Oficios e encaminhadas, via de regra, por Ofício aos órgãos destinatários. Não se conformam em processos, mas em correspondências encaminhadas pelo(a) coordenador(a) do CG ou pela gerente da Unidade. A maior dificuldade está no acompanhamento do encaminhamento das deliberações. Normalmente, não se insta nem se atua junto aos destinatários. Nos dois últimos anos a conformação do segmento usuários vem apresentando maiores níveis de liderança e conhecimento da SESAU e demais órgãos das diferentes esferas de Governo e de entidades públicas ou privadas do município, facilitando o acompanhamento e cobrança ou retorno para nova discussão.

Os conselheiros têm limitações para deliberar. De acordo com os registros das Atas e de entrevistas, deliberação para eles vem se conformando como o consenso ao qual eles chegaram e encaminhado como reivindicação às instâncias afins sobre as demandas discutidas.

De acordo com a coordenadora atual de um dos CG, deliberar significa sugerir e não mandar, não executar, só deliberar e que batalhar é negociar, é não arredar o pé (entrevista). O CG sugere. Isso é ser deliberativo? Acrescenta a coordenadora - Sou tida como ranzinza, mas me respeitam. Afirma ainda que o interesse do CG é ter o profissional afinado com a comunidade, não devem brigar. Disse que conquistaram o Distrito para desmembrar o CRS para UBS. Na realidade, o que eles conquistaram foi o direito de escolher a gerente da UBS, naquele momento, conforme diz uma funcionária da Unidade. Aliás, esta UBS, por ação do CG está sendo desmembrada do CRS. As duas Unidades na mesma estrutura estava trazendo desencontros administrativos para o Complexo. Nos demais CRS, as duas Unidades continuam na mesma infra-estrutura e com administrações independentes, mas intercomunicantes e com mútua ajuda.

A prática deliberativa - a autonomia da gestão - volta-se para opinar, aconselhar, reivindicar sobre, predominantemente, a organização dos serviços. 
As demandas levantadas nas Atas foram classificadas pelo referencial de Testa - recorte simplificado, em queixas, sugestões/reivindicações e encaminhamentos. Os encaminhamentos resultantes das deliberações/decisões foram reclassificados de acordo com o documento do ILPES/CLAPS (1975) nos componentes do processo decisório: componentes político, técnico-administrativo e técnico-operacional, em cada Conselho e, depois, numa composição de todos os CG estudados.

TABELA 19 - Distribuição numérica e comparativo dos tipos de decisões tomadas pelos Conselhos Gestores de Saúde dos CRSs e CEM - Campo Grande - M.S, 1994/ 2002

\begin{tabular}{|c|c|c|c|c|c|c|}
\hline CATEGORIA & $\begin{array}{c}\text { BAHIA } \\
\mathrm{N}^{\circ}-\%\end{array}$ & $\begin{array}{c}\text { ALMEIDA } \\
\mathbf{N}^{\circ}-\%\end{array}$ & $\begin{array}{c}\text { MORENINHA } \\
\text { III } \\
\mathbf{N}^{\circ}-\%\end{array}$ & $\begin{array}{c}\text { AERO } \\
\text { RANCHO }\end{array}$ & $\begin{array}{c}\text { CEM } \\
\mathbf{N}^{\circ}-\%\end{array}$ & $\begin{array}{c}\text { TOTAL } \\
\mathbf{N}^{\circ}-\%\end{array}$ \\
\hline Nível Político & $\mathbf{1 6 - 2 4 , 2}$ & $\mathbf{6 - 2 4}$ & $\mathbf{2 - 1 2 , 5}$ & $\mathbf{3 - 9 , 7}$ & $9-45$ & $36-22,8$ \\
\hline $\begin{array}{c}\text { Nivel Técnico- } \\
\text { Administrativo }\end{array}$ & $\mathbf{3 7 - 5 6 , 1}$ & $\mathbf{1 2 - 4 8}$ & $7-43,75$ & $16-51,6$ & $7-35$ & $79-50$ \\
\hline $\begin{array}{c}\text { Nível técnico- } \\
\text { Operacional }\end{array}$ & $13-19,7$ & $7-28$ & $7-43,75$ & $12-38,7$ & $4-20$ & $43-27,2$ \\
\hline TOTAL & $66-100$ & $25-100$ & $16-100$ & $31-100$ & $20-100$ & $158-100$ \\
\hline
\end{tabular}

Os elementos do componente político, voltam-se, predominantemente, para: implantação e divulgação de Programas; divulgação e construção de área física para o PSF; meio ambiente; Projeto do mutirão de limpeza; formas de agendamento das Unidades e do CEM; regularização do abastecimento de água em bairro; discussão do Regimento do CG; atuação dos agentes do PACS; Divulgação do CG na mídia e na comunidade; realização de eleições; questões do trânsito; atuação no planejamento ascendente; troca de coordenador para outro segmento; policial para o CRS; pedidos de ampliação da Unidade à SESAU; questões de recursos humanos; número de vagas para consultas; discussão do RI; transporte para os conselheiros; definição de papéis dos conselheiros. 
Os elementos do componente técnico-administrativo: limpeza periódica do CRS; atuação dos agentes do PACS; funcionamento do CRS; sistema de marcação de consultas; Programa do leite passar para a responsabilidade dos agentes do PACS; censo para capacitação de Conselheiros; orientação dos pacientes para uso correto dos Programas; pedido de bebedouro, torneiras fixas, pediatra para a Unidade $24 \mathrm{~h}$. e para supervisor médico do Distrito; cumprimento de horário de médicos; agilização dos medicamentos e maior agilidade na recepção; reivindicação de regularização do abastecimento de água em bairro; cascalhamento do pátio do CRS; ambiente; palestras; horas extras nos finais de semana; divulgar campanha de vacinação; permanência do técnico em RX; Educação em Saúde; tipos de atendimento; aumentar número de médicos; explicação das atividades no $24 \mathrm{~h}$; reinstalar orelhão dentro da Unidade e postes no pátio do CRS; mutirão de limpeza da área externa e na limpeza do prédio do CRS; confecção de folhetos explicativos sobre urgência/emergência; Ouvidoria; angariar torneira e fechadura nos depósitos de construção; bebedouros e vigias; aparelhos que faltam na emergência; reformas; liberação da ambulância; agendamento de especialidades; horários de atendimento dos médicos; origem dos faltosos; aquisição dos veículos Kombi e ambulância para serviços de epidemiologia e agilização do transporte das emergências;

Os elementos do componente técnico-operacional: controle das filas; análise da água num bairro da área de abrangência desse CRS; ambiente; ações anti-dengue; Rua do Lazer; ouvidoria nas filas; (Folder) sobre o atendimento do CRS; acidentes, fluxo, velocidade dos veículos; buscar dados estatísticos dos acidentes; comissão de trabalho para elaborar proposta para dia $\mathrm{D}$; capacitação de novos conselheiros pela SESAU; Reuniões semanais nas casas devido à pouca participação de esclarecimentos quanto aos serviços, prevenção e esclarecimento sobre emergência e atendimento de plantão; Vigilância Sanitária identifica áreas com sujeiras e detritos; verificar normas de higiene de um canil; orientar sobre agendamentos com especialistas e coleta de material para exames; agentes do PACS devem estar uniformizados; identificar motivos dos faltosos; a pesquisa dos faltosos feita pelos conselheiros e os agentes do PACS; caixas de sugestões colocadas na entrada do CEM; crachás de identificação para os conselheiros. 
Os números do Quadro 08 apontam para a real função que os CG das Unidades de Saúde estudas vêm desenvolvendo. O processo decisório referente ao componente político de todos os $\mathrm{CG}$ foi de $22,8 \%$; referente ao componente técnico-admnistrativo foi de $50 \%$ e técnico-operacional foi de $27,2 \%$. Os CG se agrupam, quanto ao componente político, em ordem decrescente: CEM, N. Bahia, V. Almeida, Moreninha III e Aero Rancho. Quantos aos aspectos técnico-administrativos: N. Bahia, Aero Rancho, V. Almeida, Moreninha III e CEM e, quanto ao componente técnicooperacional: Moreninha III, Aero Rancho, V. Almeida, CEM e Nova Bahia. Considerando-se o número de deliberações, pode-se afirmar que os CG considerados mais atuantes foram, em ordem decrescente, os CG N. Bahia, Aero Rancho, V. Almeida, CEM e Moreninha III. Ainda, cruzando-se os números dos três componentes do processo decisório posso afirmar que o CG do Nova Bahia foi o CG mais representativo no processo decisório, pois assume a liderança no componente administrativo e sub-lider do componente político. Se considerarmos as particularidades do CEM - referência de especialidades para o município e estado, e sua curta existência, quando comparado com o CG do Nova Bahia, o CG do Nova Bahia liderou as decisões políticas e técnico-administrativas; então, tem maior ação política.

Os números indicam que os conselheiros querem o funcionamento da Unidade e ver realizados, nos bairros, as ações das políticas públicas já determinadas nas quais - em algumas delas -, eles até atuam, numa situação de parceiros e colaboradores para a garantia da consecução de tais ações.

Muito embora se perceba nítidos avanços na organização e na prática de atuação dos Conselhos, trazendo, inclusive, avanços para a organização e produtividade técnicoadministrativa, aquela função de

caráter permanente e deliberativo, órgão colegiado composto por representantes do governo, prestadores de serviço, profissionais de saúde e usuários, atua na formulação de estratégias e no controle da execução politica de saúde na instância correspondente, inclusive nos aspectos econômico e financeiros, cujas decisões serão homologadas pelo chefe do poder legalmente constituído em cada esfera de governo" (Lei 8.142/90). 
ainda é um ponto, na sua totalidade, a ser conquistado, pois a ação no componente político está classificado em $3^{\circ}$ lugar. Deliberar, decidir, influenciar, controlar e, por conseguinte, fazer gestão participativa, é proporcional ao conhecimento das práticas políticas e orientações federais, estaduais e, principalmente, neste caso, no nível municipal.

Os conselheiros usuários, inexperientes na função deliberativa, no início, pouco se posicionavam e quando o faziam, suas colocações evidenciavam descontentamento com os serviços prestados pelo CRS, dada a sua infra-estrutura, corpo clínico, usos da ambulância, farmácia, relacionamento com os usuários, dentre outros. O CG conformou-se, inicialmente, mais em um cenário de transmissão de informações e espaço para "palpitações" do que de ação de participação plena e real, a culminar em decisões e ações efetivas e influência nas políticas sanitárias do município. Acredito que tal postura dos conselheiros era fruto de uma vivência empobrecida quanto a sua cidadania e sua atuação participativa nos problemas de sua comunidade.

Aqueles que sempre foram o objeto das ações de saúde, passavam a ser convidados por uma possibilidade legal, a serem sujeitos reais de um processo que ora começava a se construir naquela Unidade de Saúde. Como fazer gestão participativa num contexto de clientelismo e paternalismo, ainda ranços dos anos 60-70 no Brasil e com pouca informação sobre o funcionamento dos serviços de saúde pública, das leis do SUS, das questões e instrumentos de gestão, de seus direitos e deveres enquanto cidadãos? Cidadãos de uma sociedade que se apresenta democrática sem, no entanto, oferecer condições plenas de vivência da democracia, influenciando, aqui, questões sociais, econômicas e culturais, principalmente. Pessoas que, até então, "merecedoras das concessões do Estado" passavam a ser convocadas como agentes de conquistas sociais e sanitárias. Não seria a legalização de uma entidade - o CG - que traria, de pronto, a legitimidade que a legislação oferecia!

O processo atual é, respaldados pela legislação vigente, de busca de informações, treinamentos, discussões, vivências e ajustes. É um período de maturação na vivência da prática de deliberar e fazer gestão participativa em saúde pública. É preciso conhecer e 
identificar os níveis hierárquicos e niveis paralelos afins para se encaminhar e buscar aliados; mandar a mensagem clara para os Fóruns específicos e terem a devolutiva; envolvem interesses recíprocos e questões éticas para os parceiros. $O$ processo de implementação de uma política demora, muitas vezes, uma geração, o tempo para ser digerida e incorporada na cultura sócio-politica de uma população.

Os aspectos analisados apontam para algumas influências no controle e definição das Políticas de saúde para o município. Mas, o que é influenciar? É exercer influência e, esta, por sua vez, é o ato de influir. É a ação que uma pessoa exerce sobre a outra; ascendência, predomínio, poder. Influência vem do verbo influir - fazer fluir para dentro de...; inspirar, sugerir; transmitir, insuflar. Gosto das expressões fazer fluir para dentro de... e insuflar. São expressões que sugerem o poder que alguém ou um grupo tem para colocar dentro do outro o que ele acredita provocando a assimilação e apreensão, pelo outro, daquilo que se transmite.

Para isto é preciso discutir com argumentos concretos, orientados por informações reais, sugerir, sensibilizar, reivindicar, conquistar... negociar, culminando em decisões que tragam mudanças, proporcionando inflexão nas trajetórias, desfazendo "nós" das variadas situações sócio-político-sanitário-ambiental, com vistas a promover a saúde das pessoas. Esta influência estará na dependência do grau da capacidade deliberativa, da capacidade de ser gestor, resultante da autonomia dos CG das Unidades de Saúde no cenário sócio-político-sanitário do município.

Os momentos decisórios sobre as demandas transformavam-se em espaços para a criação de estratégias para influenciar, acompanhar, controlar e até intervir, em algumas vezes, nas políticas de recursos humanos, meio ambiente, Programas e serviços de saúde, Controle Social, segurança no trânsito, abastecimento de água de alguns bairros, agendamento de consultas e exames, planejamento ascendente do município. Com a experiência vivida, os conselheiros vêm avançando para a ocupação mais sistemática de espaços politico - sanitários como o CMS, o FUSUS, o FETS, o Conselho Distrital e Regional, Comitê da Dengue, Conselho do CEM com vistas a uma atuação mais direta nas políticas de saúde pública. 
O aspecto da influência do controle social e da gestão participativa na definição das políticas de saúde pública no município é uma questão que se mostrou carente de maior aprofundamento; não foi possível mensurar esta variável de estudo, na sua totalidade, durante o periodo disponível para a pesquisa. Não foi um objetivo pretensioso, mas uma tentativa de buscar o máximo de informações dentro do tempo disponibilizado para este estudo, até porque, não se tinha clareza sobre quais situações seriam encontradas. Mas foi possível perceber que, avançando-se no período, algumas influências puderam ser

percebidas. É preciso fazer um rastreamento comparando-se as decisões registradas nas Atas, Ofícios e documentos encaminhados, as respostas dos encaminhamentos e as inclusões de tais decisões nos documentos formais de politicas do município; um trabalho que ainda demanda tempo e diligente busca, além do que, muita colaboração dos coordenadores dos CG e gerentes das Unidades. E esta questão se deve ao fato de que, muitos dos documentos dos CG não estarem centralizados na Unidade, ficando, muitas vezes, em posse do coordenador, dificultando o acesso. Tal fato ocorreu em um dos CG deste estudo.

O processo vem contribuindo, num primeiro momento, para que a SESAU e a Prefeitura incorpore as demandas e estas, lentamente, passem a ser incorporadas nas políticas de saúde no município. Um exemplo dessa incorporação se deu, com maior visibilidade, no momento da construção do planejamento de saúde do município, para o período 2002 a 2005 .

\subsection{DIFICULDADES E AVANÇOS NO FUNCIONAMENTO DOS CONSELHOS}

As dificuldades identificadas no $1^{\circ}$ Encontro Municipal de Conselhos Gestores de Saúde (1996), - falta de comprometimento por parte dos usuários frente aos conselhos, falta de espaço físico para reuniões dos Conselhos Gestores, falta de conhecimento das finalidades dos conselhos Gestores por parte dos conselheiros, falta assessoria e um órgão de coordenação dos Conselhos Gestores na secretaria municipal, falta de 
credibilidade dos segmentos que compõem os conselhos - pode-se considerar não mais existentes nestes $\mathrm{CG}$, existindo, porém, alguns ranços no $\mathrm{CG}$ do $\mathrm{CEM}$, dada a sua recente criação, quando comparado com os demais. As dificuldades - para reunir os conselheiros, desmobilização pelo não atendimento das deliberações das reuniões, falta de divulgação através dos meios de comunicação ainda têm se manifestado (ATAS). Quanto à centralização do poder com a(o) secretária(o) de saúde é uma questão que avança significativamente para o caráter democrático, refletido nas ações de capacitação de conselheiros, Plenárias de Saúde do município, encaminhamentos para a separação dos CG das UBS dos CRS (atualmente um único CG), maior interação dos agentes do PACS com os conselheiros das Unidades de Saúde, ações do planejamento, (2002)dentre outros.

As dificuldades identificadas neste estudo foram: para reunir os conselheiros; desmobilização pelo não atendimento das deliberações das reuniões; reduzido comprometimento dos usuários frente aos Conselhos; reduzido conhecimento das finalidades dos conselhos Gestores por parte dos conselheiros; falta de assessoria e de um órgão de coordenação dos Conselhos Gestores na secretaria municipal (já existe mais estruturado desde 1998); falta de credibilidade dos segmentos que compõem os conselhos; alta rotatividade de conselheiros dificultando a constituição de grupos bem treinados e com experiência, provocando descontinuidade do Controle Social.

Alguns problemas se arrastam há anos, pois são pertinentes ao sistema de saúde, como, por exemplo, a velocidade na tomada das decisões, a qual é influenciada por muitos fatores interdependentes e, também, dependentes de outros setores, necessitando uma ação interinstitucional e multiprofissional para a sua realização.

No que se relaciona aos usuários, existem alguns estrangulamentos: o imediatismo, o muito senso do direito (exigências) e o pouco senso do dever (reduzida colaboração), conforme dizia uma funcionária do Setor do Controle Social. Mas, de acordo com minhas leituras das Atas e entrevistas, sinto que a maior dificuldade, e é decorrente da somatória de outras, é ser gestor. É ter o entendimento, tanto pelos conselheiros quanto pelos técnicos da SESAU, da essência da expressão - articular-se com os demais 
setores da sociedade, participar, representar a população, envolver-se no processo de formulação das politicas de saúde e no controle da sua execução (ABC do SUS 1, 1990 p. 13, 14). Ainda, participar da gestão, da gerência, da administração dos serviços de saúde pública (Lei 8.142/90).

A credibilidade nas atividades do CG está ainda comprometida. Usuários dizem que, conforme conselheiro usuário, é uma porcaria, não funciona (ATAS). Esse conselheiro usuário afirma que, diante de tantas queixas do funcionamento dos serviços, é preciso ser persistente e ter fôlego moral e espiritual! (observação de reuniōes).

O papel deliberativo nos CG estudados se manifesta em deliberar aquilo que será reivindicado às instâncias afins e tal reivindicação não garante sua consecução, comprometendo a influência nas politicas de saúde. Aliás, o acompanhamento de tais deliberações, no início do funcionamento desses $C G$, perdiam-se pelo caminho.

De uns dois anos para cá, pude constatar um maior acompanhamento, principalmente pelos usuários. Isto se explica pelo fato de, em todos os CG estudados, existir pelo menos um conselheiro usuário que acompanha as atividades desde gestões anteriores de seu Conselho. Isso favorece a garantia da resposta do encaminhamento pelo conhecimento de pessoas e processos burocráticos.

Assistindo a uma reunião, em março de 2003, de um dos CG estudados, um conselheiro usuário, coordenador de CG de outro CRS e conselheiro no seu Conselho Distrital, ao relatar reunião com a Secretária de Saúde, dizia que se fala nas leis do SUS, na Lei 8.142, mas existe uma descontinuidade no controle social, porque ninguém passa o bastão. Faz-se eleição e se começa tudo de novo. Esta postura trunca a vivência da gestão participativa e compromete a intervenção nas políticas de saúde no município.

O divisor de águas quanto à história do Controle Social em Campo Grande/M.S é 1998, quando da posse da atual Secretária de Saúde, a qual está no segundo mandato. Documentos e informações anteriores a essa data são, inexistentes ou poucos servidores sabem onde achar e detalhar os processos, pois as ações do controle social estavam 
mais vinculadas a uma ação da Secretaria de Estado do Mato Grosso do Sul e FUNASA, aliás, ao setor onde atuava a Secretária de Saúde.

Algumas dificuldades vão sempre existir, mas decorrentes de intervenções, como foi o caso destes $\mathrm{CG}$, poder-se-á ter avanços significativos para os serviços de saúde e para o funcionamento do CG: maior compreensão dos trabalhadores de saúde em relação aos objetivos dos Conselhos Gestores de Saúde; participação nas conferências distritais e municipais; integração de outros órgãos aos Conselhos Gestores, contatos com as lideranças comunitárias; amadurecimento das idéias, no aprimoramento dos conhecimentos do CG, na consciência dos conselheiros; Conselho Distrital; diretora do CRS pedia empenho do CG no planejamento 2000; o setor de Controle Social da SESAU falava da importância do CG e responsabilidade dos conselheiros; maior capacidade de organização dos conselheiros e maior articulação entre os Conselhos; maior grau de apoderamento; revisão do Regimento dos CG; maior influência no planejamento ascendente em saúde; maior sistematização no processo de capacitação dos conselheiros; maior atuação e interferência do Fórum de Usuários de saúde (representam mais ou menos 1.300 entidades e, hoje, desmembrado em Fórum dos Usuários estadual e municipal); criação do Fórum dos trabalhadores de saúde; o CG sempre é chamado a participar no dia da vacinação; os conselheiros são comunicados que houve aumento da produtividade; encontro de conselheiros na Escola de Saúde Pública para planejamento de 1998, feito em 07/97; o Prefeito vem dando abertura para os CG das Unidades de Saúde; elogio sobre o andamento e organização da reunião com participação ativa dos usuários: A participação social é muito importante (...); está havendo trabalho conjunto do gestor e da população com avanço e ganhos para a própria população"; mais conscientização dos usuários; auxilio aos diretores e gerentes das Unidades de Saúde a conquistarem melhorias no atendimento; quanto à dinâmica de funcionamento, afirmam ter melhorado, desde o inicio, pois adquiriram mais experiência e maturidade. Defendem valores como união, harmonia e compreensão. Para a atual Secretária de Saúde alguns avanços ocorreram na atuação dos Conselhos Gestores das Unidades " 24 h." "no sentido da organização dos fluxos, no acolhimento, no agendamento" (ATAS). 
Para os representantes de usuários dos serviços de saúde, ainda existe um grau baixo de institucionalização da experiência participativa, mas para os diretores de serviços, a participação vem se mostrando como um dos grandes avanços da gestão “(...) como uma forma de garantir uma relação mais democrática entre clientela e serviços" (WESTPHAL 1993, p. 90-93). Para SPOSATI \& LOBO (1992, p. 373), “ $a$ organização da representação popular em conselhos é, sem dúvida, um avanço, mas um avanço face ao autoritarismo do passado. É necessário estender o poder da representação popular à construção e gestão da politica de saúde" [e] introduzir 'cenas de negociação explicitas'.

Através dos dados documentais pude constatar que o controle, a influência $\mathrm{e}$ as interferências nas políticas de saúde estão ainda num momento tímido devido, acreditase, pela ainda reduzida informação quanto às políticas e Programas do SUS, comprometendo o principal papel dos CG - a ação política -, mas vêm conseguindo garantir maior resolutividade dos serviços, através das deliberações e encaminhamentos relativos a recursos humanos, equipamentos, melhorias na infra estrutura da Unidade, horários de atendimento, aumento na produtividade, dentre outros.

É bem verdade que a autonomia dos CG de Unidades de saúde é bastante limitada devido a sua reduzida atuação, ainda, nas questões financeiras e orçamentárias no município. Nesses aspectos, ocorrem mais sugestões e palpites que decisões. As politicas de saúde são mais criticadas que discutidas com vistas às mudanças. Isso não significa dizer que não haja interferência, mas são pequenas e lentas e proporcional ao perfil do Secretário de Saúde e do Prefeito. As maiores discussões quanto às questões orçamentárias ficam por conta dos Conselhos Municipal e Estadual de Saúde. Mas, em relação aos anos 1994 e 1996, tem-se avanços concretos.

A Resolução No 33/CNS - 23/12/92, com o objetivo de acelerar e consolidar o controle social do SUS, aprovou o documento "Recomendações para a Constituição e Estruturação de Conselhos Estaduais e Municipais de Saúde” define “(...) Conselho de Saúde como órgão ou instância colegiada de caráter permanente e deliberativo, (...) integrante da estrutura básica da Secretaria ou Departamento de Saúde nos Estados e 
Municipios (...). O Conselho consubstancia a participação da sociedade organizada na administração [grifo meu] do Sistema de Saúde, (...)". De acordo, ainda, com essa Resolução, os Conselhos são “(...) instância privilegiada na discussão da política de saúde".

No $1^{\circ}$ Congresso Nacional de Conselhos de Saúde - Sistema Único de Saúde (Salvador, abril/95), no documento TESE SISTEMATIZADA declara, quanto ao papel dos Conselhos: "Os Conselhos de Saude (...) assumem papéis muito diferenciados a partir da vontade do Executivo em democratizar ou não as decisões sobre Saúde. É preciso uniformizar e melhorar a legislação sobre as funções dos conselhos, assegurando um patamar minimo de intervenção comum, que caminhe rumo ao efetivo controle social no Sistema Único de Saúde".

Este Congresso significou um marco na história dos Conselhos de Saúde, no sentido de estar (...) empenhados em oferecer contribuições para a melhoria da Política Nacional de Saúde e (...) ainda, a concretização de uma proposta aprovada no I Encontro Nacional de Conselheiros (1994) onde 300 conselheiros discutiram aspectos referentes ao processo de democratização das decisões e da gestão em saúde e o exercicio do Controle Social através dos Conselhos de Saude. Foram debatidos, nesse I Encontro Nacional de Conselheiros de Saúde, 4 temas centrais: Papel dos Conselhos, Organização dos Conselhos, Formação de Conselheiros e Articulação entre Conselhos (Relatório Congresso Nacional de Conselhos de Saúde, 1995). As funções dos Conselhos devem ser asseguradas.

Em Campo Grande, de acordo com o Regimento dos CG e com vistas à troca de experiências e ao fortalecimento do Controle Social em Saúde Pública, vêm sendo realizadas as Plenárias dos Conselhos.

A I Plenária de Conselhos Gestores de Saúde de Campo Grande com o tema $a$ participação Popular é o caminho na Consolidação do SUS aconteceu em set./2000 e com mais de 100 conselheiros participantes dos quatro distritos sanitários. Teve como objetivo promover maior integração dos Conselhos através dos Fóruns dos Trabalhadores e Usuários do SUS e estimular intercâmbio e troca de experiências dos 
conselheiros. Afirmavam que o CG é um grupo de trabalho que exerce poder de forma compartilhada e sua composição é paritária entre três segmentos representativos da área da saúde: Usuários, Trabalhadores e Prestadores/Gestores dos Serviços Públicos de Saude (Informativo Trimestral - Controle Social, 2000).

A II Plenária foi realizada em mar./2001 com o tema Conselhos Gestores de Saúde: Participação Popular e Controle Social. Participaram mais de 120 pessoas com os seguintes objetivos: promover trocas de experiências entre os conselheiros gestores locais, estimular a participação dos conselheiros nos fóruns, discutir o papel do conselheiro e eleger delegados para a Plenária Estadual de Saúde. As principais propostas encaminhadas foram: a cada reunião do CG retirar um conselheiro para participar das reuniões dos fóruns e o coordenador do CG deverá estar presente na comunidade, nas associações de bairros e nas parcerias de trabalho com agentes de saúde.

Na III Plenária de ag./2002, um dos palestrantes afirmou que a organização dos usuários e trabalhadores em seus fóruns, colocando em pauta as necessidades da população para ser discutida e analisada por toda a sociedade, trouxe grandes avanços na área da saúde. Outro avanço foi exemplificado pela visita de representantes do Fórum dos Usuários ao Conselho Regional de Medicina, Associação Médica e Sindicato dos médicos para discutir a qualidade do atendimento médico na rede pública de saúde, pois estes grupos também estão preocupados em melhorar o atendimento.

Tem-se, nestes documentos, um espelho, um referencial para o verdadeiro papel dos CG, do ponto de vista da legalidade. Quando se analisa os momentos históricos já transcorridos é lógico constatar os ajustes que os Conselhos municipais e estaduais vêm efetivando. Os ajustes, decorrentes da vivência, vêm orientando os CG de Unidades de Saúde a, também, se espelharem nestas proposições, adequando, inclusive, seus Regimentos. Apresento um paralelo aproximado entre vários documentos quanto às competências dos conselhos e que se aplicam, alguns dos aspectos, também, aos Conselhos Gestores de Unidades de Saúde. 


\section{QUADRO 13 - PARALELO ENTRE VÁRIOS DOCUMENTOS QUANTO ÀS COMPETÊNCIAS DOS CONSELHOS}

\begin{tabular}{|c|c|c|c|c|}
\hline RES. $33 / 92$ & $\begin{array}{c}1^{\circ} \text { CONGRESSO } \\
\text { NACIONAL }\end{array}$ & $\begin{array}{c}\text { REGIMENTO DOS CG: } \\
\text { CAMPO GRANDE }\end{array}$ & $\begin{array}{c}2^{\text {a }} \text { Conferência Municipal } \\
\text { de Saúde }\end{array}$ & COMENTÁRIOS \\
\hline $\begin{array}{l}\text { 1. formulação e } \\
\text { controle da execução } \\
\text { da política de saúde; }\end{array}$ & $\begin{array}{l}\text { formular e deliberar sobre } \\
\text { política de Saúde; }\end{array}$ & $\begin{array}{l}\text { formular e deliberar sobre } \\
\text { política de Saúde; }\end{array}$ & & $\begin{array}{l}\text { A participação no controle e } \\
\text { interferência nas políticas } \\
\text { vem avançando }\end{array}$ \\
\hline $\begin{array}{l}\text { 2. estratégias e } \\
\text { mecanismos de } \\
\text { coordenação e gestão } \\
\text { do SUS; [mais no } \\
\text { nivel do CMS] }\end{array}$ & $\begin{array}{l}\text { estratégias e mecanismos } \\
\text { de coordenação e gestão } \\
\text { do SUS; }\end{array}$ & $\begin{array}{l}\text { examinar propostas e } \\
\text { deníncias; tomar as medidas } \\
\text { necessárias para permanente } \\
\text { orientação dos usuários sobre } \\
\text { os serviços oferecidos pela } \\
\text { US; participar da elaboração e } \\
\text { acompanhamento de } \\
\text { programa permanente de } \\
\text { educação em saúde das } \\
\text { comunidades; criar comissões }\end{array}$ & 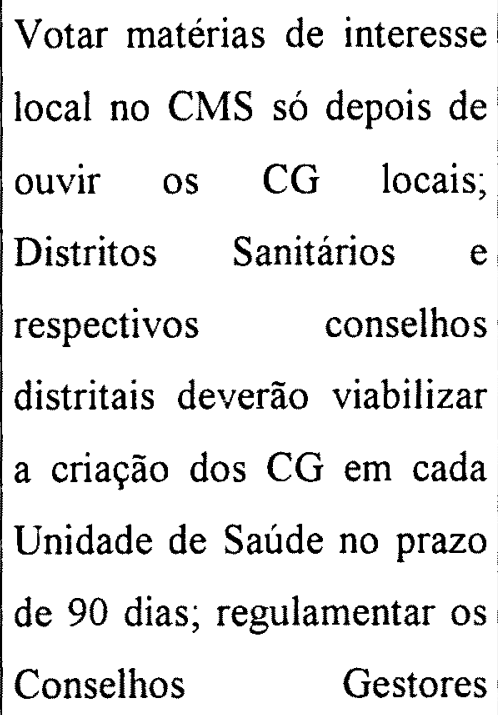 & $\begin{array}{l}\text { Os CG de todas Unidades de } \\
\text { Saúde de campo Grande } \\
\text { estão funcionando }\end{array}$ \\
\hline
\end{tabular}




\begin{tabular}{|c|c|c|c|c|}
\hline $\begin{array}{l}\text { 3. Propor medidas } \\
\text { para } \\
\text { aperfeiçoamento da } \\
\text { organização e do } \\
\text { funcionamento do } \\
\text { SUS; traçar }\end{array}$ & $\begin{array}{l}\text { proposição de medidas } \\
\text { para o aperfeiçoamento da } \\
\text { organização e do } \\
\text { funcionamento do SUS; }\end{array}$ & $\begin{array}{l}\text { de trabalho necessárias para o } \\
\text { efetivo cumprimento de suas } \\
\text { competências; Mobilizar seus } \\
\text { segmentos para escolha dos } \\
\text { representantes no Conselho } \\
\text { Distrital de Saúde; Participar } \\
\text { na Plenária Municipal de } \\
\text { Conselhos de Saúde; } \\
\text { Participar da elaboração e } \\
\text { controle da execução do } \\
\text { processo de avaliação das } \\
\text { chefias; } \\
\text { proposição de medidas para o } \\
\text { aperfeiçoamento } \\
\text { organização } \\
\text { funcionamento do SUS; }\end{array}$ & 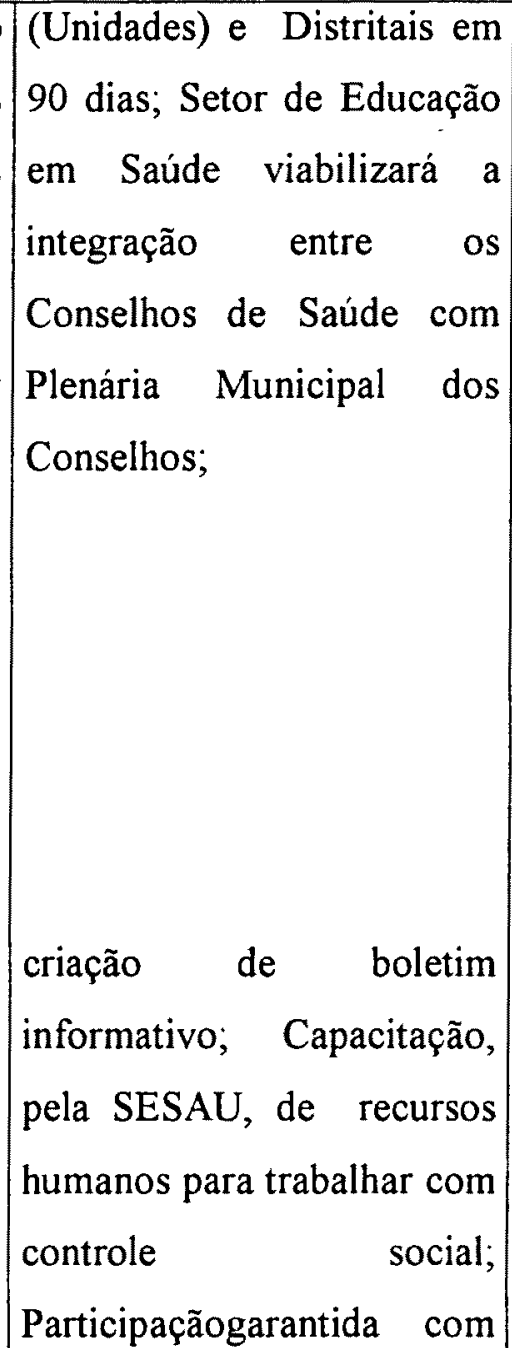 & $\begin{array}{l}\text { O prazo para a criação dos } \\
\text { Conselhos Distritais foram } \\
\text { muito alongados. Mas todos } \\
\text { já estão funcionando. } \\
\text { Funciona boletim Informativo } \\
\text { do Controle Social da SESAU }\end{array}$ \\
\hline
\end{tabular}




\begin{tabular}{|c|c|c|c|c|}
\hline $\begin{array}{l}\text { diretrizes de } \\
\text { elaboração e aprovar } \\
\text { os planos de saúde; }\end{array}$ & & & $\begin{array}{l}\text { doação do } r \text { transporte; } \\
\text { Organizações } \\
\text { participam dos } \\
\text { de Saúde deverão investir } \\
\text { na formação de seus } \\
\text { conselheiros e da sua base }\end{array}$ & $\begin{array}{l}\text { funciona sistematicamente. } \\
\text { Processo de capacitação de } \\
\text { conselheiros mais sistmáticos. }\end{array}$ \\
\hline $\begin{array}{lr}\text { 4. Estimular } & \text { a } \\
\text { participação } & \\
\text { comunitária } & \text { no } \\
\text { controle } & \text { da } \\
\text { administração } & \text { do } \\
\text { SUS; } & \end{array}$ & $\begin{array}{l}\text { estimular a participação } \\
\text { comunitária no controle } \\
\text { da administração do } \\
\text { Sistema de Saúde; }\end{array}$ & $\begin{array}{l}\text { estimular a participação } \\
\text { comunitária no controle, } \\
\text { manutenção } \\
\text { desenvolvimento das ações de } \\
\text { saúde; [ d de rorma } \\
\text { desarticulada] }\end{array}$ & $\begin{array}{l}\text { Divulgação das ações do } \\
\text { CG; }\end{array}$ & $\begin{array}{l}\text { de forma assistemática e com } \\
\text { o apoio dos agentes do PACS }\end{array}$ \\
\hline $\begin{array}{lr}5 . & \text { Examinar } \\
\text { propostas } & e\end{array}$ & $\begin{array}{l}\text { criar mecanismos que } \\
\text { assegurem um canal de }\end{array}$ & $\begin{array}{l}\text { Examinar propostas e } \\
\text { denúncias }\end{array}$ & Criação de ouvidoria & $\begin{array}{l}\text { Ouvidorias funcionando em } \\
\text { todos os CG }\end{array}$ \\
\hline
\end{tabular}




\begin{tabular}{|c|c|c|c|c|}
\hline $\begin{array}{l}\text { deníncias; responder } \\
\text { a consultas sobre } \\
\text { assuntos pertinentes; } \\
\text { [isso acontece] }\end{array}$ & $\begin{array}{l}\text { comunicação com a } \\
\text { sociedade não organizada } \\
\text { de forma a facilitar a } \\
\text { apresentação de } \\
\text { deníncias, (...); } \\
\text { [de forma assistemática, } \\
\text { mas usam o rádio e a TV } \\
\text { em programas populares] }\end{array}$ & & & \\
\hline $\begin{array}{l}\text { 6. fiscalizar e } \\
\text { acompanhar } \\
\text { desenvolvimento das } \\
\text { ações e serviços de } \\
\text { saúde; [somente no } \\
\text { nivel do CRS] }\end{array}$ & $x^{2}$ & $\begin{array}{l}\text { Fiscalizar e acompanhar o } \\
\text { desenvolvimento das ações e } \\
\text { serviços }\end{array}$ & $\begin{array}{l}\text { Levantamento sobre o grau } \\
\text { de satisfação } \\
\text { comunidade em relação aos } \\
\text { serviços; }\end{array}$ & $\begin{array}{l}\text { OUVIDORIA MUNICIPAL } \\
\text { - pelo telefone } 137\end{array}$ \\
\hline $\begin{array}{l}\text { 7. Propor critérios } \\
\text { para a programação e }\end{array}$ & $\begin{array}{l}\text { desenvolver ações } \\
\text { conjuntas com órgãos dos }\end{array}$ & $\begin{array}{l}\text { Participar das avaliações de } \\
\text { Recursos Humanos da }\end{array}$ & $\begin{array}{lr}\text { Planejamento, a } & \text { partir de } \\
1996, \quad \text { de } & \text { forma }\end{array}$ & $\begin{array}{l}\text { Planejamento ascendente a } \\
\text { partir de } 2002 \text { de maneira }\end{array}$ \\
\hline
\end{tabular}




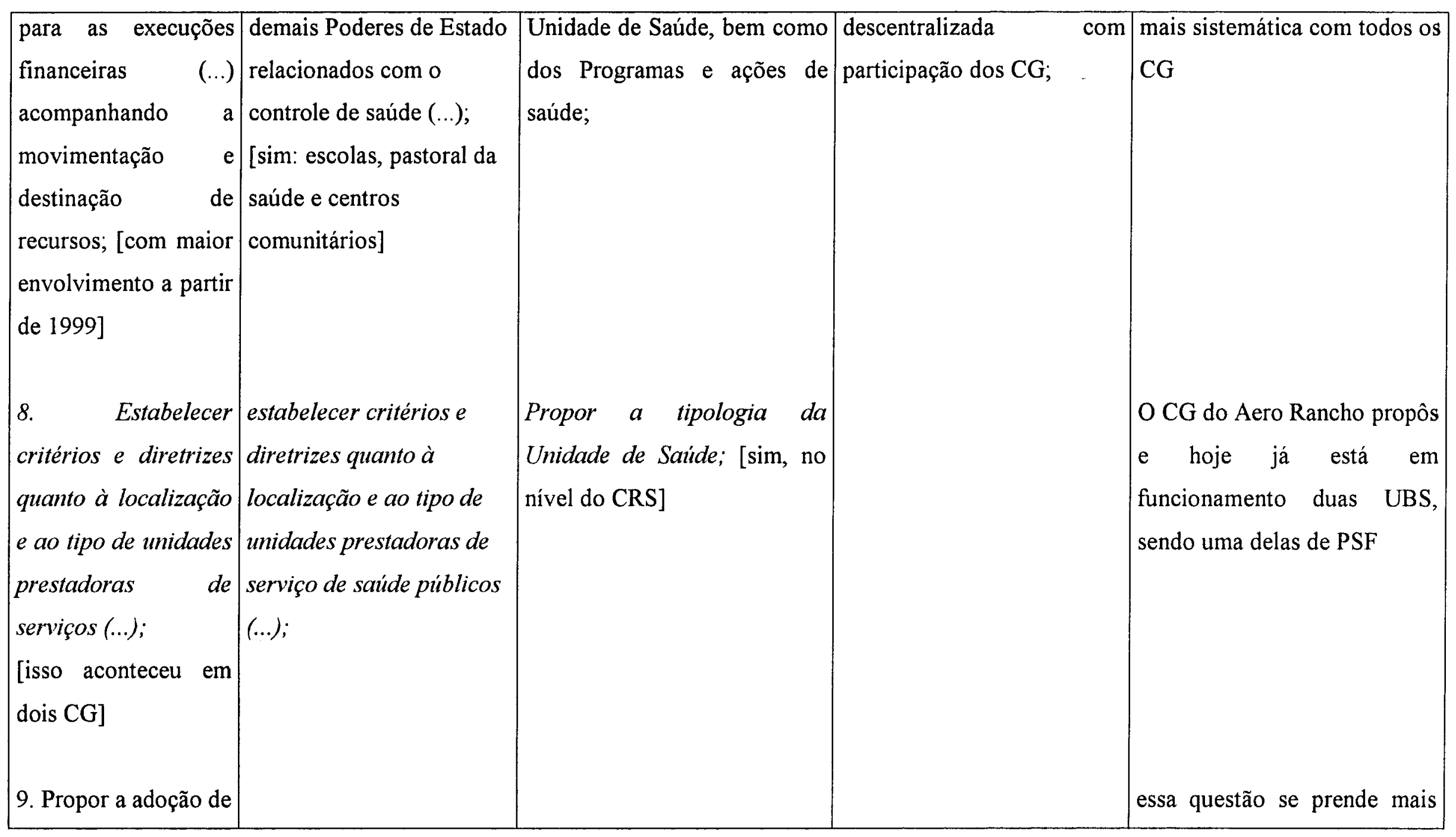




\begin{tabular}{|c|c|c|}
\hline $\begin{array}{l}\text { critérios que definam } \\
\text { qualidade e melhor } \\
\text { resolutividade; }\end{array}$ & & $\begin{array}{ll}\text { ao agendamento das } \\
\text { consultas, atendimento na } \\
\text { recepção, compra de } \\
\text { equipamentos e presença de } \\
\text { médicos em todos os turnos }\end{array}$ \\
\hline $\begin{array}{l}\text { 10. Elaborar o } \\
\text { Regimento Interno }\end{array}$ & & 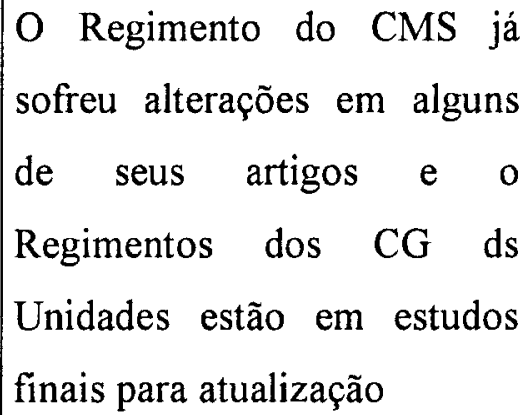 \\
\hline $\begin{array}{l}\text { 11. criar recursos a } \\
\text { respeito de } \\
\text { deliberações do } \\
\text { Colegiado; }\end{array}$ & 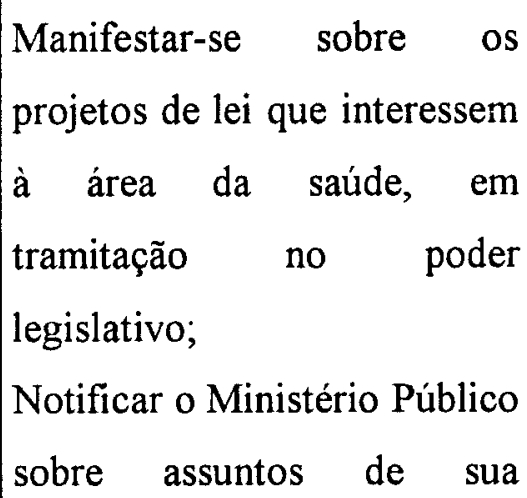 & $\begin{array}{l}\text { Estas atividades vêm sendo } \\
\text { feitas pelo CMS, em especial, } \\
\text { em relação ao controle da } \\
\text { Dengue, para reduzir } \\
\text { dificuldades com imóveis } \\
\text { fechados. }\end{array}$ \\
\hline
\end{tabular}




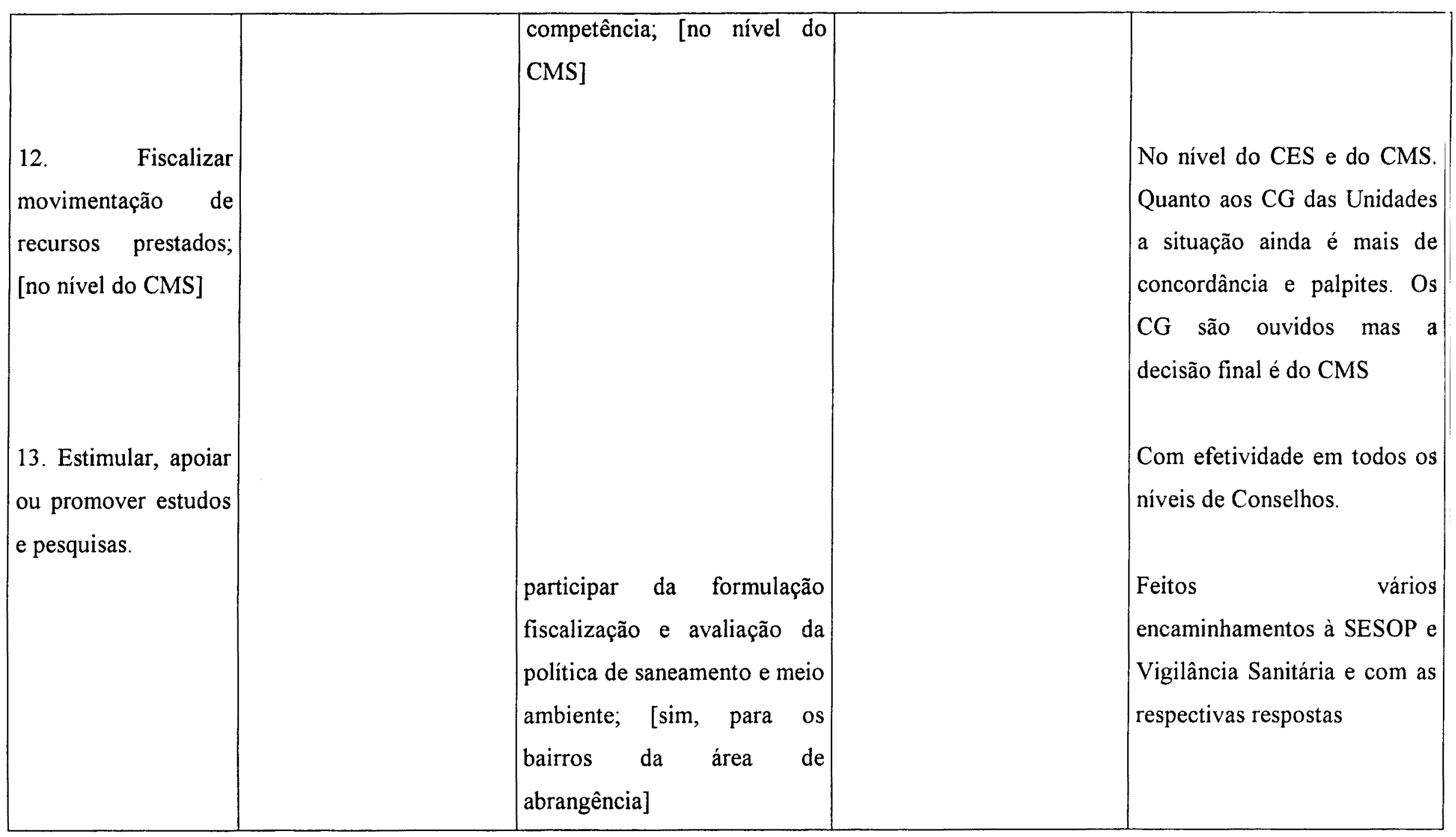


Estas informações socializadas, analisadas e discutidas podem trazer orientações políticas substanciais para a ação deliberativa e a prática da gestão participativa em saúde pública. $\mathrm{O}$ (des)conhecimento destes elementos fará a ponte entre a legalidade e a legitimidade - e o tamanho da distância entre estes dois marcos vem sendo construída a partir da dinâmica e velocidade dos movimentos sociais institucionalizados no Controle Social.

\subsection{CONTROLE SOCIAL: LEGALIDADE X LEGITIMIDADE}

A legalização do controle social nos anos 90 é, sem dúvida, fruto de movimentos sociais ascendentes na busca por uma participação real e plena no cenário sócio-político brasileiro. Quando se analisa a evolução histórica da participação popular, culminando num processo de controle social institucionalizado, tem-se a impressão, na linha do tempo, que assim como evolui o processo teórico-propositivo e legal, de caráter ideológico, evolui também a prática sanitária-social. Isto não é real. Existe distância entre um direito garantido constitucionalmente e um direito sanitário a ser implementado. Essa legalidade não garante legitimidade, haja vista a necessidade de um tempo que permita se vivenciar e sentir os resultados de um processo que depende, dentre outros fatores, do acesso dos cidadãos à informação', de uma cultura participativa nos mais variados segmentos da sociedade civil e política, mesmo porque ainda pesam sobre os ombros dos cidadãos brasileiros as dificuldades e entraves para se viver a democracia que se nos apresenta novamente como possível em meados dos anos 80, depois de duas décadas de autoritarismo. De acordo com estudos feitos por WESTPHAL (1993, p. 90-93), representantes das direções de serviços de saúde afirmam que "(...) pelo fato de tratar-se de uma relação que está se construindo, o processo é muito lento, e que as unidades descentralizadas têm poucos meios para desenvolver seu trabalho". Este cenário se mostra em grande desafio para a ação dos conselhos de saúde e, também, para os CG dos CRS estudados. São visíveis muitos

\footnotetext{
${ }^{1}$ Para Jacobi (1992. p. 35), a questão não é meramente informar, “(...) mas explicitar e tornar transparentes e abertos os canais de negociação".
} 
avanços desde 1994, nos CG estudados, mas ainda existem inúmeras dificuldades e barreiras que se apresentam e precisam ser gradativamente superadas, como diz GOHN (1995, p. 329), "num tempo eticamente aceitável".

O Plano Diretor da Reforma do Aparelho do Estado (BRASIL, 1995), ao apresentar as três formas da administração pública - Administração Pública Patrimonialista, Administração Pública Burocrática e Administração Pública Gerencial - afirma que esta última constitui um avanço. Emerge na Segunda metade do século XX e apresenta como essencial, "a necessidade de reduzir custos e aumentar a qualidade dos serviços, tendo o cidadão como beneficiário". Tal forma de administração apresenta algumas características: estar voltada para o interesse público, esperando-se que o interesse coletivo seja atendido; vê o cidadão como cliente dos seus serviços. Este Plano de Reforma do Estado enquadra o setor saúde dentre os serviços não-exclusivos e, embora situe o cidadão como beneficiário dos serviços, apresenta como objetivos

\footnotetext{
lograr adicionalmente um controle social direto desses serviços por parte da sociedade através dos seus conselhos de administração. Mais amplamente, fortalecer práticas de adoção de mecanismos que privilegiem a participação da sociedade tanto na formulação quanto na avaliação do desempenho da organização social, viabilizando o controle social [grifo meu].
}

A sociedade deve exercer um controle social direto nos serviços através de conselhos de administração, permitindo fortalecer práticas de adoção de mecanismos que privilegiem a participação da sociedade tanto na formulação quanto na avaliação do desempenho da organização social, viabilizando o controle social (Idem).

A experiência de Botucatu (1992), embora, quanto ao Conselho Municipal, apresenta algumas dificuldades que também se mostram nos CG de Unidades. Por exemplo, naquele Conselho, a expressão deliberativo fora excluído da minuta (em forma de Projeto de Lei) do Regimento Interno, aprovado pelo conselho Municipal de Saúde, em 1992. Quando da posse do novo prefeito em 1993, o mesmo se sentiu no direito de fazer tal abuso e devolveu para a Câmara dos Vereadores e sem receber o aval do Conselho. 
Embora tenha dado um pouco de desgaste técnico-administrativo, 1/3 dos conselheiros convocou reunião extraordinária e deliberaram (grifo meu) "que o prefeito deveria retirar o projeto da Camara para que fosse rediscutido no Conselho, e assim foi feito, voltando a palawra deliberativa, porém, acrescido de um parágrafo único: a deliberação só terá validade após apreciação pelo COMUS” (MORITA et al, s.d.). A postura dos conselheiros evidencia que o poder do controle social, quando desempenhado no momento certo e para finalidades cidadãs traz dividendos sóciosanitários significativos.

A experiência do municipio de São Paulo em gestão participativa nos anos 1989-92, sob a administração petista, evidenciou, de acordo com JACOBI (1992, p. 38-9), que existem inúmeras limitações para a conformação de uma parceria governo do município e sociedade civil, quais sejam: dificuldades em se construir canais regulares de participação em escala significativa, cultura política e sua fragilidade, do ponto de vista organizacional e institucional, cultura burocrática e centralizadora, desafio de se assegurar legitimidade junto aos setores como alvo prioritário da administração, desarraigamento da maior parte da população em relação às práticas participativas, existência reduzida ou quase inexistência de embriões de poder popular que possam incentivar a participação e à organização popular, disposição menos voluntarista da administração e de setores dos serviços de saúde pública em tratar as questões de participação, movimentos populares com baixa visibilidade, dificultando a formulação de demandas, fragilidade dos mecanismos de comunicação e informação, imprecisão existente nos papéis dos diversos agentes e à indefinição do processo de decisão e das competências de poder, dentre outros.

Secretários de Saúde presentes no Encontro de Secretários Municipais de Saúde de Olinda, em 1988, expressaram na Carta de Olinda que "a desorganização da sociedade civil e o baixo nivel de conscientização da sociedade, por dificuldade de acesso da população à informação" (1988) contribuem para atrasar e impedir que a população exerça maior participação no controle social dos serviços de saúde. 
Ainda, o fato da população não ter alcançado um patamar de cultura "considerada político-democrática", e não ter se capacitado para assumir o controle social como "uma interlocução regulada e institucionalizada", tem dificultado a democratização do sistema de saúde e da sociedade (WESTPHAL 1992, p. 25).

Nos estudos de WESTPHAL (1993, p. 90-93), para os representantes de usuários dos serviços de saúde, ainda existe um grau baixo de institucionalização da experiência participativa, mas para os diretores de serviços, a participação vem se mostrando como um dos grandes avanços da gestão “(...) como uma forma de garantir uma relação mais democrática entre clientela e serviços"

SANTANA (1990, p. 59) já afirmava o que foi constatado nestes CG que, até o despreparo nas questões de estruturar reuniões, estabelecer regras e limites que possam regular a participação, tem contribuído para um desempenho comprometedor, culminando em resultados pouco visiveis. Para SPOSATI \& LOBO(1992, p. 375), “os momentos de reunião dos conselhos não podem ser simples conversas que não penetram a instituição. (...) É necessário ter claro o canal, ou canais, pelo qual ocorre a interferência na dinâmica da instituição, seja um hospital, uma unidade básica, uma diretoria, uma empresa etc.". Vai se construir muito mais um espaço de conflitos do que de consenso; vai fazer nascer um elemento complicador: a complexidade, manifesta pelo "(...) convívio de múltiplos sujeitos e interlocutores na construção democrática". Tal situação poderá terminar na ausência de decisões, conformismo e sensação de incapacidade de mudar.

Outro grande entrave na efetivação do controle social é o perfil dos profissionais de saúde pertencentes a alguns Conselhos e possuem uma formação muito pobre nas questões sociais, fruto de uma formação fragmentada e conservadora. Poucos estão preparados e sensibilizados para uma cumplicidade nas questões sanitárias, pois que pouco valorizam, pouco acreditam e pouco respeitam o ideário da Reforma Sanitária, dificultando, inclusive, a possibilidade de uma participação social real e plena dos conselheiros, emudecendo técnicos e usuários nos momentos que deveria prevalecer uma postura democrática, numa visão de co-gestão e deliberação e não, simplesmente, 
numa situação de endossar decisões tomadas anteriormente e à revelia dos conselheiros.

A criação dos CG em Campo Grande vem desde 1994 mas, de acordo com depoimentos da atual Secretária de Saúde de Campo Grande,

\begin{abstract}
A efetivação dos Conselhos Gestores é posterior a 1998 e fruto da consolidação dos movimentos populares, a partir das Oficinas de capacitação de Conselheiros que foram desencadeadas pela FUNASA em 1996 e 1997, em parceria com o gestor estadual e a Universidade Federal de Mato Grosso do Sul. Eu ocupava o cargo de Coordenador Regional e tinhamos uma linha de trabalho de Educação para a Participação em Saúde, a qual incluía a formação de conselheiros e a mobilização das comunidades para o controle social Ao assumir a SESAU, promovi a organização do setor de apoio ao controle social, que assumiu o trabalho na mesma linha, inclusive com servidores que vieram da própria FUNASA.
\end{abstract}

A atual Secretária de Saúde de Campo Grande/M.S colocou, também, que

o fato do CG ser único nas Unidades que funcionam no mesmo espaço fisico das Unidades Regionais (CRS), misturando, inclusive, os niveis de atenção, e o fato do setor de urgêncialemergência se confundir com o pronto atendimento faz gerar um problema para todos, gerentes e conselheiros. Discussões atuais indicam o caminhar para a separação dos espaços fisicos das Unidades, e com certeza facilitará a gestão e o controle social.

As dificuldades encontradas na dinâmica de funcionamento dos CG se aproximam com as análises de AROUCA (1987, p. 15) quanto à experiência de São Paulo, nos anos 80 , e relatos de JACOBI (1992, p. 32), e demais autores referenciados neste estudo. Mas pode-se constatar, pelos registros das Atas, observações e entrevistas que tais dificuldades, presentes no início do processo do Controle Social, através dos Conselhos de Saúde estudados, tendem, muitas, a ceder, fruto das vivências cotidianas, como por exemplo, e principalmente: reduzido e/ou fragmentado acesso às informações, corporativismo, reduzido nível de organização e conscientização da comunidade, compromisso do corpo de funcionários, suporte institucional para interação com 
movimentos populares, dificuldade de encaminhamentos e das propostas de participação, dificuldades para conciliarem interesses sociais e econômicos. Aliás, encontrei conselheiros mais antigos que indicam, pelas suas falas, conhecerem melhor as pessoas, processos, canais de encaminhamentos, demais entidade e fóruns, permitindo obter mais informações, contribuindo para facilitar as decisões e encaminhamentos.

WESTPHAL (1993, p. 90-93) declara que “(..) existem problemas nos fluxos de informação e hostilidade de parte dos funcionário, principalmente, com relação aos setores mais organizados, porque estes são vistos freqüentemente como elementos perturbadores”. Também, “(...) existem resistências por parte dos profissionais para modificar a prática tradicional, principalmente do pessoal universitário".

Quero acrescentar que, na questão colocada acima, por AROUCA (1987, p. 15) e WESTPHAL (1993, p. 90-93), respectivamente, reduzido e/ou fragmentado acesso às informações e problemas nos fluxos de informação, a problemática também reside na interpretação destas informações e em como colocá-las como ponto de partida para a solução dos problemas. Para uma população, grupo social ou um Conselho pouco preparado em questões sócio-politico-sanitárias, pode-se até identificar problemas, mas mais importante que isto, é procurar explicar as causas destes problemas para, então, melhor se vislumbrar as alternativas viáveis para a sua solução. Ou ainda, um problema deixa de ser problema quando não existem informações necessárias para, diante de um fato, conformá-lo como problema. A informação abre as portas para o conhecimento, para as indagações, para os questionamentos, para as buscas, podendo os Conselhos conformar-se em espaços educativos, ao se tornarem locus de produção de conhecimento.

Para DUSSAULT (1992, p. 12),

os usuários nem sempre têm a informação para definir suas necessidades e a maneira de atendê-las. (...) permanece uma falta de informação que os coloca em posição de subordinação potencial diante do profissional. (...) uma compreensão mais completa 
dos problemas pode diminuir a amplitude das mudanças a serem efetuadas para resolvè-los. Já é um modo de ser mais eficiente.

BARROS (s.d.) defende a idéia de que,

\begin{abstract}
Por ser um órgão que tem que deliberar sobre o que precisa ser feito e fiscalizar as ações do governo, os Conselhos precisam estar permanentemente informados sobre quais são os problemas de saude da população, quais os recursos disponiveis para a área da saúde, onde e como estão sendo aplicados. Os gestores não podem se recusar a dar as informações que os conselheiros precisam para avaliar e tomar decisões.
\end{abstract}

Esta ação de controle socializado ajuda a definir. Identificar estes problemas e saber quando e como começar a enfrentá-los é ainda desafio para os gestores nos três niveis da administração pública. WESTPHAL (1995, p. 47) afirma que "o espaço de participação se configura em arenas politicas no qual se desenvolvem cenários de confronto e linhas de solução para o conflito". "Não um confronto pela negação mas, sim, pela diferença de posição, para inclusive, construir um campo de negociação.

A participação, e não a postura opinativa - a postura de "palpitação", neste processo de controle social é que vai estimular o potencial dos indivíduos para serem protagonistas de sua própria história. Amplia sua consciência sanitária e permite que a rede das Unidades de Saúde se configurem num lugar, efetivamente, resolutivo e inovador de novas práticas de saúde. Permite priorizar a prevenção, humanizar a relação instituiçãousuário, melhora a equidade no atendimento, contribui para reinventar a gestão social. Os indivíduos e grupos sociais se assumem como sujeitos sociais ao interagirem com o sistema de construção de novas metodologias e desenvolvem seu próprio modo de construir seu próprio projeto. De acordo com Matus, "desenvolvem sua própria capacidade de governo". O impacto será maior quanto maior for a organização destes sujeitos sociais. SANTOS \& CARVALHO (1992, p. 60) afirmam que "o estágio de uma cultura influencia o nivel de participação". Tal cultura gera um senso de responsabilidade e esta objetiva uma obrigação de responder por algo que a autora denomina de accountability e depende ou acompanha o avanço de igualdade, dignidade humana, participação e incorporação de sujeito ativo no processo. 
GRAMSCI advertia que "o processo de criação dos intelectuais é longo, dificil, cheio de contradições, de avanços e de recuos, de cisões e de agrupamentos [e que sua evolução é] 'muito mais lenta que a de qualquer outro grupo social em razão de sua natureza mesma e de sua função social' (referido por AMMANN, 1978 p. 25)

Ainda para GRAMSCI (referido por TESTA, s.d.), "devemos ser pessimistas na razão e otimistas na vontade".

Os dados indicam que, por conta do otimismo de muitos conselheiros destes CRS estudados, a prática do Controle Social na perspectiva da Gestão Participativa vem se fortalecendo, apresentando até, em alguns momentos, alguns recuos, mas com um saldo positivo em relação aos avanços, principalmente, caminhando em busca de uma prática política mais concreta trazendo subsídios ao processo de planejamento, conforme o verificado em 2002 .

A análise dos documentos, das entrevistas e o pano de fundo da bibliografia revisada me dão segurança para afirmar que, quanto à dinâmica do funcionamento dos Conselhos Gestores de Saúde estudados e a prática da ação deliberativa e função de gestão participativa e influência nas políticas de saúde, os avanços são facilmente perceptiveis Posso situá-los em três momentos e através de algumas ações:

\section{Em processo adiantado de construção:}

medidas de aperfeiçoamento da gestão dos serviços: Plenárias de Saúde como instrumento educativo e de reflexão, estudo do Regimento Interno, Oficina de capacitação, estabilidade da paridade, ação fiscalizadora dos serviços, maior organização dos Conselhos, maior controle no encaminhamento das decisões, estruturação de reuniões com debates mais concretos e objetivos, atuação mais comprometida dos trabalhadores e prestadores de serviços, postura democrática nas reuniões, discussão e decisão sobre as questões de organização, resolutividade e qualidade do atendimento da Unidade, conhecimento dos recursos humanos, materiais e Programas desenvolvidos, decidindo as prioridades, fiscalizar e acompanhar a política de saneamento e meio ambiente, formulação de demandas amarradas com a realidade sócio-sanitária e ambiental; 
$\checkmark$ crescimento de espaço politico e administrativo: maior integração com os Fóruns dos Usuários e Trabalhadores do SUS, maior representação dos CG nos CMS e no CG do CEM, sugestões para os Programas de saúde e localização de Unidades e/ou serviços, articulação interinstitucional;

$\checkmark$ interferência na dinâmica da instituição e do setor saúde: por decisões administrativas nas reuniões do $\mathrm{CG}$ e maior proximidade de alguns conselheiros com a rotina da Unidade, atuação no planejamento de ações e serviços de saúde no município;

$\checkmark$ análise de propostas e denúncias: Ouvidoria;

2. Em processo lento de construção:

$\checkmark$ influência $e$ controle das politicas: com maior autonomia administrativa e capacidade deliberativa, definição clara dos papéis dos conselheiros, fluxo e interpretação de informações, conhecimento dos recursos financeiros, estímulo da participação social no controle, ações conjuntas com outros poderes;

$\checkmark$ espaço politico e decisório: barreiras de poder, experiência da gestão participativa, reduzida representação e representatividade dos conselheiros, acesso às informações político-sanitárias, redução do corporativismo profissional, relação de maior igualdade entre os segmentos dos Conselhos, divulgação do uso correto dos serviços de saúde, divulgação das ações dos CG;

$\checkmark$ competência e habilidade para provocar mudanças: questões culturais do processo participativo, reduzido senso de cidadania, uso da mídia e demais canais de informação para sensibilização e pressão, educação em saúde em parceria com entidades dos bairros, adoção de critérios que definam qualidade e resolutividade, informações sobre legislação e direitos sanitários, Conselho como espaço de construção de conhecimento e espaço educativo.

\section{Ainda não operacionalizado ou com presença incipiente:}

$\checkmark$ embriões de poder popular para incentivar a organização popular: lideranças comunitárias, competências de poder - não estão claras, investimento na formação dos conselheiros por parte das entidades que representam, avaliação dos Programas, recursos humanos e das chefias (apenas fazem comentários), acompanhamento da elaboração do Plano de trabalho da Unidade de Saúde; 
Ficam aqui alguns questionamentos: qual o nivel de interesse da burocracia municipal em atender as queixas dos conselheiros? Quais os recursos disponiveis para minimizar tais queixas?

Pode-se dizer que o momento é muito mais de construção do que de consolidação das ações do Conselho, mas, considerando como ponto de partida, o inicio do processo, em 1994, já se caminhou bastante e o processo de construção e controle das políticas sanitárias vem sendo significativo. Urge a criação de estratégias que venham contribuir para acelerar a construção e a consolidação de caminhos efetivos para este controle. Encontramos, na prática, Conselhos de Saúde mais ou menos significativos. Sua atuação vai estar diretamente ligada à maturidade técnica, politica e social de seus conselheiros.

Este caminho será concreto quando o planejamento ascendente em saúde continuar se construindo, sistematicamente, na ótica do controle social, com uma participação representativa capaz de definir prioridades sócio-sanitárias para uma coletividade, tendo as informações necessárias de caráter social, técnico, administrativo, político, dentre outros, disponíveis, e onde a crítica, a reflexão, a discórdia e a contradição, embasadas no pluralismo de idéias venham apontar para um cenário verdadeiramente democrático. Ter-se-ão sujeitos de direitos, sujeitos da história, direitos de cidadãos.

Esta trilha construida no imaginário estará na dependência dos vários elementos acima elencados. A tendência, sem dúvida, será a caminhada numa trilha contraditória, que se constrói em cima de experiências acumuladas do cotidiano, mas que mesmo a reboque de outras políticas públicas parece avançar no fortalecimento da cidadania e na conquista de direitos sociais, devendo sempre mover-se no rumo de uma utopia, o combustível da máquina social, e, neste caso, no rumo do fortalecimento das forças sociais. Há que se ocupar os espaços, principalmente, aqueles resultantes de conquistas sociais, acreditando que 
8. CONCLUSÃO 
A extensiva coleta de dados deste estudo teve a finalidade maior de mostrar os meandros do funcionamento de CG de Unidades de Saúde combinando vários recursos no estudo da experiência dos Conselhos gestores do município de Campo Grande pelo período de quase 10 anos. Considerando-se, então, este amplo corpo de informações, vejo neste estudo uma contribuição significativa para se repensar o controle social e gestão participativa exercido pelos $\mathrm{CG}$ de Unidades de Saúde. Considero estes resultados um marco para uma reflexão sobre o real papel dos CG de Unidades de Saúde no contexto das políticas do SUS.

Considerando os resultados e a análise, anteriormente, apresentada, tem-se a considerar:

Os CG dos CRS foram criados por iniciativa do Executivo Municipal. Os CG se organizam em plenário com coordenador, secretário, calendário anual de reuniões ordinárias e extraordinárias, registros em Atas, em composição paritária (com maior respeito pela paridade de 2 a 3 anos para cá), periodicidade, ainda com algumas curtas pausas e encaminhamentos das reivindicações/decisões.

No inicio, os conselheiros usuários se revestiam de muito poder em beneficio próprio e em querer determinar procedimentos na Unidade de Saúde. O CG do CEM, por ter se iniciado em 1997, ainda enfrenta algumas situações desse tipo. Existe reduzida articulação dos lideres de bairros com os conselheiros e com dificuldades de repasse de informações do Conselho para os líderes. A substituição no segmento usuários é freqüente e a reduzida representação dos bairros e entidades compromete a representatividade, principalmente, nos três primeiros anos de funcionamento. É reduzida, também, a capacidade de liderança, principalmente entre os conselheiros usuários, empobrecendo o cenário político nos CG. O Fórum de Usuários e de Trabalhadores de Saúde vêm exercendo papel significativo servindo como bases sociais para os conselheiros.

Conselhos criados mais cedo (1994) tiveram maior tendência para pausas prolongadas, pois a SESAU e os conselheiros detinham pouca vivência no processo e o imediatismo não conferiu a paciência necessária para ir se construindo. Contribuiu, também, para as 
pausas o retrocesso de 1996, pela não implementação das propostas colocadas pelos conselheiros e por instabilidade política na SESAU.

No inicio, quem mais representava era o segmento prestador. Dizia um conselheiro que o CG tem que ter uma envergadura do secretário. Nesse período se tropeça; é uma fase de aprendizagem. Os movimentos sociais que exerceram alguma influência nos CG foram a Pastoral da Criança e da Saúde e algumas associações de bairros, com vistas a extensão dos serviços de saúde e a melhoria na qualidade das informações, tanto quanto ao funcionamento dos serviços de saúde quanto ao funcionamento do $\mathrm{CG}$ no intuito de aproximar a população ao processo do Controle Social em Saúde.

No início do funcionamento os CG fazem um maior número de reuniões. Os mais antigos tiveram pausas mais prolongadas. A coordenação dos $C G$, no inicio eram de usuários e vêm caminhando para um predomínio de coordenação de prestadores de serviços. Não há pauta pré-estabelecida para reuniões, na maioria dos CG.

A prática de atuação e função deliberativa do CG segue a dinâmica: as discussões se iniciam voltadas para queixas/reclamações dos serviços oferecidos pela Unidade, acusações em relação às rotinas dos serviços e da qualidade do atendimento, infraestrutura da Unidade de Saúde, condições ambientais e para questões e informações básicas do funcionamento dos serviços prestados, avançando para questões sanitárias, epidemiológicas, com pouca freqüência, e encaminhamentos mais concretos. As queixas geram reivindicações e sugestões mas, nem sempre, assumem a formalidade deliberativa, interferido, aqui, a ausência de autonomia quanto a orçamentos. As deliberações são encaminhadas via Oficio. Nem sempre se conhecem os caminhos ideais para destinar os encaminhamentos. Decidem o que reivindicar e não, precisamente, quando será feito.

Até 1998 as ações do CG indicavam mais para fiscalização que deliberação. A medida que o tempo avançava estas dificuldades ficavam reduzidas pois os conselheiros iam conhecendo pessoas, a regulamentação do SUS, processos burocráticos, dentre outros. 
Não querem seguir sozinhos, querem o apoio da Secretária de Saúde e sindicato dos médicos que representa os trabalhadores, ouvindo os usuários (ATAS).

A prática, ainda, mais fortemente presente é uma gestão consultiva, palpitativa; mas com avanços para uma gestão mais participativa. O Fórum dos Usuários e o Fórum de Trabalhadores vêm dando suporte para a criação de estratégias para se enfrentar situações e questões necessárias com vistas a fortalecer a capacidade deliberativa.

Não foram constatadas situações conflitantes. Apresenta-se uma prática democrática e de respeito recíproco entre os segmentos. Hoje, não se percebe direta e/ou formalmente disputa de poder entre os segmentos. Mas ocorria, com mais evidência, no início da atuação dos CG. Os segmentos prestadores e usuários são os que mais falam nas reuniōes.

Quanto às decisões tomadas pelo CG os conselheiros discutem, consultam-se e a "outrens", ponderam, examinam, opinam, sugerem, palpitam, aconselham, votam e decidem o que reivindicar. O papel deliberativo fica mais na perspectiva da gestão da organização dos serviços que no controle e na implementação das politicas.

A influência no controle e implementação das políticas vem tendo peso maior do segmento prestador, através do $\mathrm{CG}$, haja vista sua maior permanência no CRS, detêm um maior número de informações sobre o SUS e a rotina do sistema de saúde no município.

De acordo com informações aqui apresentadas e as análises baseadas nos componentes do ILPES/CLAPS (1975) constatou-se uma maior influência, até 2002, dos componentes técnico-administrativo e técnico-operacional no processo decisório relativos à gestão participativa dos CG. Do ponto de vista quantitativo o $\mathrm{CG}$ que mais conseguiu influenciar no controle e formulação de políticas de saúde foi o CG do CRS do bairro Nova Bahia. Aliás, este CG, foi o que mais atuou nos processos políticos e administrativos. Os Conselhos de Unidades têm sido gestores mais nos aspectos administrativos que políticos, pois a maioria das demandas voltam-se para a 
organização e resolutividade dos serviços. Nesse cenário mesclado de conquistas e desafios, torna-se necessário avançar para minimizá-los rumo ao fortalecimento dos processos para um funcionamento mais resolutivo.

Tem-se avanços nítidos. Dentre os já apresentados na análise deste estudo destacam-se: estão mais organizados na dinâmica do funcionamento, resultante da vivência do processo e na interação com o fórum dos usuários e dos trabalhadores de saúde; maior respeito à paridade; maior grau de respeito pelas entidades municipais; funcionamento anual de Plenárias de Saúde para discussão do Controle Social. Tem-se avanços nas negociações intra e inter-entidades. As mudanças no $\mathrm{CG}$ são reflexos das mudanças na sociedade, mudanças estas que retroalimentam e fortalecem sua dinâmica de funcionamento.

Alguns entraves estruturais, técnicos, políticos e sociais para o controle social se destacam das dificuldades encontradas: a maioria não conhece a rotina dos serviços de saúde, os caminhos e procedimentos burocráticos da SESAU. Conhecem pouco a legislação do SUS e o entendimento mais amplo do Controle Social resultando em uma ação mais consultiva que deliberativa, comprometendo a gestão participativa. Encontram barreiras para intervir na política de recursos humanos, setor alvo de muitas críticas. Os trabalhadores são concursados, mas as chefias são cargo de confiança, dificultando a intervenção dos conselheiros para substituições quando as mesmas passam a não responder aos interesses dos serviços e dos usuários. Estes entraves associados aos reduzidos niveis de representação e representatividade comprometem a gestão participativa. A gestão participativa esbarra nos entraves colocados anteriormente e na atual performance dos conselheiros - com déficit na quantidade e na qualidade das informações necessárias ao processo de gestão dificultando a competência de ser gestor. Estas dificuldades se transformam em desafios a serem transpostos como a passagem de ator social para ator sóciopolítico - para a sociedade civil; aprender a conviver com novos processos onde há parceria, onde os administradores não são os únicos a decidirem - para a sociedade política estatal e o desafio de construir espaços de interlocução entre sujeitos sociais diferenciados, representando atores sociais, políticos, culturais distintos e de origem heterogênea. 
Estes CG encontram-se em estágio intermediário entre uma gestão reivindicatória, relacionada a serviços oferecidos pelas Unidades de saúde, recursos humanos, questões com o ambiente, mais informações sobre o funcionamento do Conselho para a população, e um despertar para uma gestão deliberativa e participativa, ao garantir a inclusão de demandas no planejamento de saúde no município, a partir de 2002.

Os avanços na prática da participação social, nos espaços do Controle Social, vêm fortalecendo a atuação direta no processo de planejamento do município na possibilidade de intervenção nas políticas de saúde pública. Espera-se um avanço maior do envolvimento no processo decisório das questões orçamentárias para o município de Campo Grande/M.S através dos usuários-conselheiros presentes no CMS.

Feitas estas considerações acredito poder apontar algumas ações necessárias ao fortalecimento do Controle Social e da gestão participativa no contexto da legalidade do Controle Social no SUS:

Em relação à organização e representatividade: fomentar a representação dos bairros e entidades para fortalecer a representatividade através da divulgação das atividades dos CG e respostas mais imediatas dos encaminhamentos - redução da distância entre o pensar e o agir; respeito à paridade - isto reduz o "hierarquismo" e promove eficácia; divulgar o que é controle social; autonomia; divulgar o SUS: isto vem sendo feito nos murais; quem não vem à Unidade pouco fica sabendo da dinâmica dos serviços e das políticas, implementar boletins informativos de Unidades, maior participação dos funcionários nas reuniões do $\mathrm{CG}$, mais empenho dos conselheiros; maior ação dos agentes do PACS; ação dos conselheiros nos bairros - igrejas, clubes, escolas, creches.

Quanto à prática de atuação e função deliberativa: maior articulação entre os Conselhos e fóruns afins: encontros e seminários. Os conselheiros sugerem reuniões entre Prefeito, médicos, Conselhos, Posto de saúde e Associação de Moradores. Isto cria vínculo entre as pessoas e identidade com o segmento, abre canais confiáveis de comunicação, desmistificado, inclusive, a terminologia do SUS - os iniciantes não conseguem compreender o rito e a dificil linguagem da área da saúde; agenda 
antecipada para os conselheiros se prepararem com informações e coragem, principalmente, dos usuários para discutir e deliberar; estimular a cultura participativa pela mídia, na divulgação de informações de interesse coletivo, com ética, transparência e fidedignidade, em programas populares; esclarecimentos sistemáticos sobre o papel dos CG das Unidades de Saúde; estimular os conselheiros a conhecerem melhor a realidade sócio-ambiental-cultural e sanitária que ele representa; clareza dos problemas e dos objetivos a serem alcançados, devendo estar mais articulados com suas bases; distribuição de responsabilidades e dos resultados; maior integração com a rotina e cultura institucional - conhecer a Unidade; sustentação do diálogo; mais informações quanto às políticas do SUS; conhecer o cenário político e burocrático para se obter respostas mais rápidas; usar momentos das reuniões como momentos educativos nas questões do Controle Social; melhorar fluxo de informações e comunicação entre os níveis hierárquicos e paralelos; avaliar sistematicamente o funcionamento do CG para identificação de dificuldades na prática do controle social; capacitação continuada após processo de eleição dos conselheiros e durante o período de gestão, sempre que a situação exigir, a partir de situações-problemas reais. Os conselheiros sugerem reciclagens constantes através de oficinas, palestras, mini-cursos, conferências, e com profissionais competentes; preparo dos conselheiros que permita garantir respaldo político e técnico necessário ao cumprimento da função deliberativa (ATAS).

Para uma atuação mais eficiente torna-se necessário reduzir a descontinuidade no controle social através do incentivo à continuidade de alguns conselheiros. Não estou aqui defendendo a recondução ilimitada dos conselheiros, num exercício de representatividade vitalícia, mas enquanto não existe um processo amplo de preparo para novos conselheiros, essa seria a forma de se garantir, ainda que truncada, uma certa efetividade e continuidade no Controle Social em cada $C G$, pois permite um novo grupo iniciar contando com a experiência de alguém ou de alguns que já vinha atuando nessa prática social, garantindo uma certa velocidade inicial ao trabalho. Esse aprendizado de alguns ajuda no treino dos conselheiros mais novos.

A implantação das decisões e influência nas políticas vai depender, diretamente, de apoio da Secretaria de Saúde e sindicatos que representam os prestadores, ouvindo os 
usuários; ocupação de espaços de poder nos vários niveis da sociedade civil com reuniões e panfletos: escolas, igrejas, clubes de mães e similares e centros comunitários, para sensibilizar e informar as pessoas sobre as rotinas e o uso correto dos serviços de saúde. Muito mais do que estar "a serviço de" é preciso "ir ao serviço da ...". Ainda, aprender a pensar e agir estrategicamente; participação ativa e direta do Fórum dos Usuários do SUS na formulação dos procedimentos das Oficinas de Capacitação, com indicação de temáticas necessárias à formação do perfil de conselheiros; trabalho articulado entre as esferas de governo com vistas ao fortalecimento do funcionamento dos Conselhos; atuação deliberativa orientada para contribuir na mudança do modelo assistencial, privilegiando as ações de promoção da saúde, mas não em detrimento das assistenciais. A Universidade precisa, através dos currículos, contemplar conteúdos da área da saúde coletiva, nos vários cursos, preparando profissionais com maior capacidade de interpretação dos fatos sociais, interagindo com as comunidades através da criação de metodologias e modelos que fortaleçam a indissocialidade do ensino, pesquisa e extensão.

Diante destas proposições e no intuito de minimizar os entraves técnico-estruturais julgo necessário um processo constante de capacitação dos conselheiros que os habilite a atuar no contexto dos componentes do processo decisório: político, técnicoadministrativo e técnico-operacional. Mesmo que a gestão participativa venha tendo como demandas as questões da organização e resolutividade dos serviços, os conselheiros precisam se munir de tais conhecimentos. Estarão, também, se preparando para identificar pontos frágeis nas políticas de saúde, podendo e devendo indicar objetivos e metas necessárias à construção e fortalecimento do SUS.

Se a legitimidade dos Conselhos for a meta realmente desejada, necessário se faz dotar os conselheiros de ferramentas que lhes permitam intervir nas politicas de saúde através de capacitação com elementos técnicos, administrativos, politicos e sanitários, de direitos sanitários, legislação do SUS, dentre outros, para se vislumbrar com maior transparência os elementos intervenientes no processo saúde-doença para uma ação mais concreta na promoção da saúde e com vistas a uma ação mais integralizadora tendo na epidemiologia o instrumental para compor os conteúdos necessários para cada 
situação. A epidemiologia vai indicar demandas mais racionais. Os conselheiros de saúde, não importa em qual segmento e em qual nivel de governo estejam, precisam conhecer orientações sanitárias de caráter epidemiológico, por mais básicas e simplificadas que sejam, como as informações relativas ao "campo de saúde" (DEVER, 1988), quais sejam": estilo de vida, ambiente, organização dos cuidados com a saúde e biologia humana, modelo este aceito e referendado por vários estudos epidemiológicos.

Em relação ao estilo de vida, deve-se identificar, valores culturais, conceito de saúdedoença e seus determinantes, fatores de risco - chance de ocasionalidade: identificar atitudes e comportamentos - interpessoal, social, ecológico, em relação à saúde, participação nos cuidados com a saúde -, das populações de risco e fatores de risco na sua comunidade. Ainda: sexo, faixa etária, escolaridade, renda per capita; densidade demográfica; tipos de moradia; infra-estrutura da região; acesso às informações; organizações sociais, dente outros.

Em relação ao ambiente: aspectos geográficos - relevo; rios, córregos e lagoas; rodovias; vias de acesso aos serviços; transportes. Ambiente propriamente dito: destino e coleta de resíduos sólidos e águas residuais; vetores; saneamento básico; presença de entidades poluentes, terrenos baldios, asfaltamento, disponibilidade de bens e serviços, forma de produção. Deve-se perceber ainda, de acordo com DEVER ${ }^{1}$, as questões sócio-culturais, economia, educação, emprego, etc.

Em relação à organização dos cuidados com a saúde interessa conhecer aspectos associados à prevenção, cura, cuidado e reabilitação da área de abrangência: quais são os serviços disponiveis, quem utiliza, lacunas no uso do serviço, infra-estrutura, organização, recursos humanos, origem e disponibilidade dos recursos financeiros, sistema de informação dos serviços, incapacidades. Ainda, conhecer a politica de saúde, suas doutrinas e diretrizes, tanto para poder participar da programação das ações, quanto da execução, do controle e avaliação, sempre no enfoque da prevenção da doença e proteção e promoção da saúde. Precisam também conhecer as necessidades e problemas 
de saúde da sua comunidade; indices de morbimortalidade, origem e agentes causadores destes agravos, grau de satisfação dos usuários, serviços de referência.

No que tange à biologia humana/hereditariedade, ter informações sobre expectativa de vida, tecnologias e serviços disponiveis para um diagnóstico precoce e recuperação, no intuito de contribuir para permitir a inserção de individuos ditos "deficientes" na sociedade.

Com este instrumento poder-se-á focar com maior integralidade e transparência as questões necessárias e passíveis de serem revertidas em beneficio da melhoria da qualidade de vida de indivíduos e grupos sociais.

O desenho da estratégia de ataque aos problemas de saúde dos grupos sociais será mais preciso quanto mais eficiente for o controle social e este será na proporção da qualidade das informações disponiveis. Conhecedores de sua realidade e com tais informações, os conselheiros de saúde terão o embasamento politico, técnico, legal, ambiental e social necessário para colocar proposições e deliberar a favor dos interesses de seu grupo social.

Para se concretizar tais ações tem-se como elemento maior a informação, considerada um dos pilares da participação. Se está conselheiro é preciso aprender a ser conselheiro para se reduzir os desencontros do ensaio e erro. E a informação é um dos componentes do processo de aprendizagem. É necessário educar para a participação através de um esforço pedagógico que possa provocar mudanças de comportamento social, promovendo habilidades, reduzindo frustrações, insatisfações, apatias, fortalecendo a dinâmica do controle social e a efetividade da gestão participativa. $O$ capital humano precisa ser preparado, formado e capacitado para participar no processo, não só de identificação do problema, mas, e principalmente -, de construção de caminhos e estratégias políticas.

Este processo de capacitação deve se dar de maneira continuada, através de Oficinas em forma de módulos, por temáticas de interesse e necessidades que o momento possa 
demandar, dirigidas, especificamente, para cada segmento e com momentos de integração entre os segmentos e entre os CG das Unidades de Urgência do Municipio. Estas Oficinas devem ser realizadas para CG de Unidades de Urgência e para Unidades Básicas, em separado, por terem objetos distintos de controle e gestão, podendo ser organizadas pela SESAU, mas assessoradas, diretamente, pelos Fóruns dos Usuários dos SUS, Fórum dos Trabalhadores da Saúde, sindicatos e movimentos sociais organizados em saúde. Mas deve, também, haver momentos de integração entre estes diferentes formatos de CG - de Unidades de Urgência e Básicas, para discussão das problemáticas que os aproximam.

Além de se repassar e discutir informações, acredito que o objetivo maior seja contribuir para formar mentes criticas e detentoras de conhecimento que permitam identificar as necessidades e causas específicas, propor situações e ações alternativas que tragam as respostas e os resultados almejados. Os conteúdos necessários são aqueles circunscritos pela legislação do SUS, conteúdos técnico-administrativos básicos, a serem identificados pelos próprios conselheiros, informações de cunho epidemiológico - os propostos pelo campo de saúde de DEVER (1988), aspectos de relações interpessoais e liderança, que possam contribuir para a construção de diagnósticos situacionais, haja visto que as Oficinas de capacitação e Plenárias de Saúde até agora realizadas vêm se preocupando mais com o papel dos conselheiros, princípios do SUS e forma de funcionamento dos $\mathrm{CG}$. Um processo educativo que contemple a igualdade na diversidade de formação e funções com vistas a reduzir a desigualdade na igualdade formal. 
9. REFERÊNCIAS BIBLIOGRÁFICAS 
Ammann SB. Participação social. 2ed. São Paulo: Cortez \& Moraes; 1978.

Ammann SB. Movimento Popular de Bairro. São Paulo: Cortez; 1991.

Arouca ASS. O Planejamento de saúde em uma sociedade em transição. Saúde em Debate; 1987.

Azevedo CS. Planejamento e Gerência no Enfoque Estratégico-Situacional de Carlos Matus. Cad. Saúde Pública 1992; 8 (2): 129-33.

Barros E. O controle social e o processo de descentralização dos serviços de saúde. Campinas: Instituto de Economia da UNICAMP; s. d.

Bógus CM. Participação popular em saúde: formação política e desenvolvimento. São Paulo: Annablume/FAPESP; 1997.

Brandão C R, organizador. Pesquisa participante. São Paulo: Cortez; 1987.

Brasil. Lei $\mathbf{N}^{\circ}$ 8080. Dispõe sobre as condições para a promoção, proteção e recuperação da saúde, a organização e o funcionamento dos serviços correspondentes e dá outras providências. Brasília: MS; 1990.

Brasil. Lei 8142/90. Dispõe sobre as formas de participação da população no SUS. Brasilia: MS; 1990.

Brasil/Ministério da Saúde. Resolução $\mathbf{N}^{\mathbf{0}}$ 33. Conselho Nacional de Saúde. Dispõe sobre Recomendações para a constituição e estruturação de Conselhos Estaduais e Municipais de Saúde. Brasilia; 1992.

Brasil/Ministério da Saúde. Norma Operacional Básica; 1996. 
Brasil/Ministério da Saúde. Resolução 196. Conselho de Ética em Pesquisa. Dispõe sobre recomendações e orientações para questões éticas em pesquisas com seres humanos. Brasília; 1996.

Brasil/Ministério da Saúde. ABC do SUS 1. Brasilia; 1990

Carvalho G, Santos L. Sistema Único de Saúde. Comentários à Lei Orgânica da Saúde. 2ed. São Paulo: HUCITEC; 1995.

Cecílio LCO, Mehry EE. Planejamento e gestão dos serviços em defesa da vida. São Paulo: CEFOR; 1992. (Cadernos CEFOR, textos, 5)

Cervo A, L BERVIAN PA. Metodologia Cientifica. São Paulo: McGraw-Hill do Brasil; 2000.

Chile/Ministério de Salud. Programación Local Participativa - Programa de Capacitación en Promoción de la Salud para equipos de Salud; s.d (Unidad I e III).

Cohn A, Elias P, Jacobi P. Participação Popular e Gestão de Serviços de Saúde: um olhar sobre a experiência do Município de São Paulo. Saúde em Debate, № 38, 1993.

Congresso Nacional de Conselhos de Saúde. Tese Sistematizada. Salvador; 1995.

Costa NR. A transição democrática e movimentos sociais: contribuição ao debate da Reforma Sanitária. In: Demandas populares, políticas públicas e saúde. Petrópolis: Vozes; 1989.

Demo P. Participação é conquista. São Paulo: Cortez; 1998.

Dever GEA. A Epidemiologia na Administração dos Serviços de Saúde. São Paulo: Pioneira; 1988. 
Dussault G. A gestão dos serviços públicos de saúde: características e exigências. Rev. Adm. Pública; 1992, 26 (2):8-19.

Estado do Mato Grosso do Sul/Conselho Estadual de Saúde. ASP - grupo 9

Estado do Mato Grosso do Sul/Assembléia Legislativa. Lei $N^{\circ} 1.152$ de 22/06/92. Dispõe sobre a criação do Conselho Estadual de Saúde de Mato Grosso do Sul.

Estado do Mato Grosso do Sul/Conselho Estadual de Saúde. Deliberação No 030; DOE 08/03/95.

Estado do Mato Grosso do Sul/Secretaria de Estado da Saúde. Programa de Capacitação de Conselheiros de Mato Grosso do Sul. Campo Grande/MS: Conselho Estadual de Saúde; 1995.

Estado do Mato Grosso do Sul /Secretaria de Estado da Saúde. Programa Estadual de Capacitação de Conselheiros Municipais de Saúde. Campo Grande/MS; s.d.

Estado do Mato Grosso do Sul /Conselho Estadual de Saúde. Programa de Capacitação de Conselheiros de Mato Grosso do Sul. Campo Grande/MS; 1995.

Estado do Mato Grosso do Sul /Conselho Estadual de Saúde. Deliberação $\mathbf{N}^{0} \mathbf{0 4 6 /}$. Dispõe sobre as orientações para organização e funcionamento dos Conselhos de Saúde no Estado de Mato Grosso do Sul; 1997.

Estado do Mato Grosso do Sul/Secretaria de Estado da Saúde. Oficina “Os Conselhos de saúde numa abordagem participativa" - Relatório de Atividades. Campo Grande/MS; 1997.

Estado do Mato Grosso do Sul/Secretaria de Estado da Saúde/Núcleo de Educação em Saúde. Relatório de Atividades da Oficina: Os Conselhos de Saúde numa Abordagem Participativa. Campo Grande/MS; 1997. 
Evangelista OP. Orientações básicas para o processo de planejamento em saúde. Saúde em Debate, Nº 44; 1994.

Fundação Nacional de Saúde. Manual do Conselheiro Gestor de Saúde. Campo Grande: Fórum dos Usuários de Saúde/Fórum de Trabalhadores de Saúde; 1996.

Genro T, Genoíno J. Folha de S. Paulo, São Paulo, 22-3-1995, seção Tendências e Debates. p. 3

Gohn MG. Teoria dos movimentos sociais: paradigmas clássicos e contemporâneos. São Paulo: Edições Loyola; 1995.

ILPES/CLAPS. Formulación de políticas de salud. Washinton (DC): OPS; 1975. cap. 1 e 2.

Jacobi P. Estado capitalista: transformações na dinâmica de intervenção e papel das burocracias. In: Movimentos Sociais e políticas públicas: demandas por saneamento básico e saúde: São Paulo, 1974-84. São Paulo: Cortez; 1989.

Jacobi P. Participação e gerência dos serviços de saúde: desafios e limites no Município de São Paulo. Rev. Adm. Pública, 1992; 26(2): 32-43.

Jacobi P . Políticas sociais e ampliação da cidadania. 1ed. Rio de Janeiro: Ed. FGV; 2000 .

Kodjaoglanian VL. Descentralização do Sistema de Saúde em Mato Grosso do Sul, 1984-1994: Contribuição de uma política de desenvolvimento de Recursos Humanos. Campo Grande; 1997. [Dissertação de Mestrado: Universidade Federal de Mato Grosso do Sul]

Mehry EE. Planejamento ascendente: será que os municípios têm algo a dizer sobre 
isto, para a montagem do SUS? Saúde em Debate, № 39; 1993.

Mimayo, MCS. O desafio do conhecimento: pesquisa qualitativa em saúde. 2 ed. São Paulo: HUCITEC/ABRASCO;1993.

Morita I, Figueiredo MS, Silva RMF. A participação popular na gerência do sistema Único de Saúde: erros e acertos da experiência de Botucatu - SP. Botucatu: UNESP; s.d.

Organización Mundial de la Salud. Atención primária de salud: Alma-Ata 1978 [on line]. Disponivel em URL: http://whqlibdoc.who.int/publications/9243541358.pdf [2003 out 23]

Organização Mundial da Saúde. Carta de Ottawa [on line] In: Primeira Conferência Internacional sobre Promoção da Saúde; 1986; Ottawa, CA. Disponível em URL: http://www.opas.org.br/promocao/uploadArg/Ottawa.pdf [2003 out 23]

Pinto JB. Ação educativa através de um método participativo no setor saúde. In: Ação Participativa: Metodologia. In: Anais do Encontro de Experiência de Educação e Saúde da Região Nordeste, Brasília: Centro de Documentação do Ministério da Saúde; 1982.

Plano diretor da Reforma do Aparelho do Estado. Brasília: Presidência da República, Câmara da Reforma do Estado, Ministério da Administração Federal e Reforma do Estado; 1995.

Prefeitura Municipal de Campo Grande/Secretaria Municipal de Higiene e da Saúde Pública. Lei $\mathbf{N}^{\circ}$ 2.784. Dispõe sobre a criação do conselho Municipal de Saúde; DOM 1990.

Prefeitura Municipal de Campo Grande/Secretaria Municipal de Higiene e da Saúde Pública. Decreto No 6.340. Regulamenta a Lei No 2.784. DOM 02/08/91. 
Prefeitura Municipal de Campo Grande/Secretaria Municipal de Higiene e da Saúde Pública. Lei $\mathbf{N}^{0}$ 2.811. Dispõe sobre a nova redação dos artigos $1^{\circ}, 6^{\circ}$ e seus parágrafos $1^{\circ}$ e $2^{\circ}$ da Lei $N^{\circ} 2.784$. DOM 07/06/1991.

Prefeitura Municipal de Campo Grande/Secretaria Municipal de Higiene e da Saúde Pública . Lei $\mathbf{N}^{\circ}$ 3.013. Dá nova redação ao artigo $6^{\circ}$ e seus parágrafos $1^{\circ}, 2^{\circ}$ e $4^{\circ}$, da Lei $N^{\circ}$ 2.784. DOM 30/11/93.

Prefeitura Municipal de Campo Grande/Conselho Municipal de Saúde. Regimento Interno. Campo Grande: M.S: DOM № 4107; 1995.

Prefeitura Municipal de Campo Grande/Conselho Municipal de Saúde. Deliberação $\mathbf{N}^{\mathbf{0}}$ 05. Aprova o Regimento Interno dos Conselhos Gestores de Saúde, e dá outras providências. DOM 23/08/95.

Prefeitura Municipal de Campo Grande/Secretaria Municipal de Saúde. Relatório final da $2^{a}$ Conferência Municipal de Saúde. Campo Grande/MS; 1996.

Prefeitura Municipal de Campo Grande/Secretaria Municipal de Saúde. RELATÓRIO DO $1^{\circ}$ ENCONTRO MUNICIPAL DE CONSELHOS GESTORES DE SAÚDE. Campo Grande/MS; 1996.

Prefeitura Municipal de Campo Grande/Secretaria Municipal de Saúde. Relatório final da $2^{a}$ Conferência Municipal de Saúde. Campo Grande/MS, 1996.

Prefeitura Municipal de Campo Grande/Câmara Municipal de Campo Grande. Lei Orgânica do Município de Campo Grande/MS; 1999.

Prefeitura Municipal de Campo Grande/Secretaria Municipal de Saúde.Informativo do Controle Social. Ano I N 003. Campo Grande/MS; 2000. 
Prefeitura Municipal de Campo Grande/Secretaria Municipal de Saúde. I Plenária Municipal de Conselhos de Saúde: Avaliação do Controle Social no SUS e o Papel dos Conselheiros de Saúde. Campo Grande/MS; 2000.

Prefeitura Municipal de Campo Grande/Secretaria Municipal de Saúde. Relatório Final da $3^{\mathrm{a}}$ Conferência Municipal de Saúde. CONSTRUINDO O SUS: ATÉ ONDE CHEGAMOS? Campo Grande; 2000.

Prefeitura Municipal de Campo Grande/Secretaria Municipal de Saúde/PLANURB. Perfil sócio-econômico de Campo Grande/M.S. Campo Grande/M.S: PLANURB; 2001 .

Prefeitura Municipal de Campo Grande/Secretaria Municipal de Saúde /Secretaria Municipal de Saúde. II Plenária Municipal de Conselhos de Saúde: Avaliação do Controle Social no SUS e o Papel dos Conselheiros de Saúde. Campo Grande/MS; 2001 .

Prefeitura Municipal de Campo Grande/Secretaria Municipal de Saúde /Secretaria Municipal de Saúde. Oficina Pedagógica: Conselhos Gestores de Saúde numa abordagem participativa. Campo Grande: Serviço de Apoio ao Controle Social; 2002.

Prefeitura Municipal de Campo Grande/Secretaria Municipal de Saúde /Secretaria Municipal de Saúde. III Plenária Municipal de Conselhos de Saúde: Campo Grande/MS; 2002.

Prefeitura Municipal de Campo Grande/Secretaria Municipal de Saúde/Secretaria Municipal de Saúde. Plano Municipal de Saúde - 2002/2005. Campo Grande/MS, 2002.

Pupo TRGB. Participação dos Conselhos Municipais de Saúde no processo decisório de formulação e implantação das políticas de saúde: estudo de caso em dois municípios em gestão semi-plena. São Paulo, 1999 [tese de mestrado - 
Faculdade de Saúde Pública - USP]

RADIS-Proposta FIOCRUZ. CARTA de Olinda. Rio de Janeiro; 1988 8(6).

Rede Ida: Boletim; 1993, 12: 3.

Reis EMS. Conselhos de Saúde: limites e possibilidades do processo de participação: um estudo sobre o Conselho Estadual de Saúde de Mato Grosso do Sul - CES/MS.2000. Campo Grande; 2001. [Dissertação de Mestrado - Universidade Federal do Mato Grosso do Sul]

ROCHA FLX. Direitos Fundamentais na Constituição de 1988. In: MORAES, Alexandre de. Os 10 anos da Constituição Federal. São Paulo: EDUSP; 1998.

Sá ENC. Contradições e conflitos nas formas de organização da Administração Pública para o Sistema Único de Saúde. In: Saúde e Revisão Constitucional. Controle Social e formas organizacionais do SUS. Série Direito e Saúde $n^{\circ} 2$. Brasília: OPAS; 1992.

Santana JP. Municipalização da saúde: desafios para a cooperação técnica. Saúde em Debate 1990; (30): 59-60.

Santos L, Carvalho GI. Das formas de controle social sobre as ações e os serviços de saúde. Saúde em Debate, N $N^{\circ}$ 34; 1992.

Sposati A, Lobo E. Controle Social e Políticas de Saúde. Cad. Saúde Pública; 1992 8(4): 366-378.

Sposati A, Lobo E. Controle Democrático e e protagonismo popular; s.d.

Stanisci SA. Conselhos de Assistência Social: tendências e perspectivas. São Paulo: FUNDAP; 1996. 
Testa M. Pedaços de discurso de um profissional de saúde que se sabe fazendo história. Secretaria Executiva Rede UNIIDA; s.d.

Tojal SBB. Constituição dirigente de 1988 e o Direito à Saúde. In: Moraes A. Os 10 anos da Constituição Federal. São Paulo: EDUSP; 1998.

Tripodi T . Avaliação de programas sociais. Rio de Janeiro: Francisco Alves; 1984.

Universidade de São Paulo/Faculdade de Saúde Pública. Guia de Apresentação de Teses. São Paulo: A Biblioteca; 1998.

Uribe FR. Aspectos históricos do planejamento de sáude na América Latina. Saúde em Debate. s.d.

Valla VV . Participação popular e saúde. Petrópolis: CDDH/CEPEL; 1989.

Westphal MF. Participação Popular e Políticas Municipais de Saúde: o caso de Cotia e Vargem Grande Paulista. São Paulo, 1992. [Tese de Livre Docência. Faculdade de Saúde Pública de São Paulo/USP].

Westphal MF. Movimentos sociais e comunitárias no campo da saúde como sujeitos e objetos de experiências educativas. Saúde Soc 1993; 3(2):127-48.

Westphal MF. Gestão Participativa dos serviços de saúde: pode a educação colaborar na sua concretização? Saúde em debate $N^{\circ}$ 47, 1995. 
ANEXOS 


\section{FORMULÁRIO PARA OS DOCUMENTOS}

FORMULÁRIO PARA COLETA DE DADOS DAS ATAS DE REUNIÕES, REGIMENTOS, LEGISLAÇÃO, DENTRE OUTROS

1. Data de criação do conselho:
2. Processo de escolha dos conselheiros:
a. eleição
b. indicação

3. Composição:

\begin{tabular}{|l|l|}
\hline Categoria & $\mathbf{N}^{\mathbf{o}}$ \\
\hline Usuários & \\
\hline Trabalhadores/administração & \\
\hline Prestadores de serviços & \\
\hline
\end{tabular}

4. Regularidade das reuniões (calendário):

5. Representatividade (segmentos sociais):

6. Demandas (pauta/atas):

7. Encaminhamentos (para quem?):

8. Participação dos representantes do Conselho por segmento. 


\section{ROTEIRO DE OBSERVAÇÃO}

1. Constatar o papel legal e real dos conselheiros.

2. Captar a lógica dinâmica e contraditória do discurso de cada ator social e de seu relacionamento com os outros atores.

3. Detectar os tipos de alianças.

4. Verificar se, no processo de gestão participativa das ações locais, o conselho tem ação de controle social ou de consultoria social.

5. Quem fala?

6. Como fala

7. Para quem fala (direta/indiretamente)

8. Por quem fala (direta/indiretamente)

9. Valores e idéias defendidas 
$\mathrm{Eu}$, RG concordo em participar da Pesquisa "Controle Social e Gestão Participativa - um estudo realizado com Conselhos Gestores de Saúde de Unidades de Urgência/Campo Grande - MS, 1994 - 2002", através deste questionário, cujo objetivo básico é conhecer a analisar a dinâmica do funcionamento destes Conselhos. Não autorizo divulgar meu nome mas somente o segmento do Conselho ao qual pertenço. Reconheço que esta pesquisa vai contribuir para o avanço das questões do controle social em saúde no município.

Campo Grande, $07 / 03 / 2003$

Nome e assinatura

Fone: pesquisadora - Milca Lopes de Oliveira

(11) $5821: 8495$

\section{ROTEIRO DE ENTREVISTA SEMI-ESTRUTURADA}

\section{a. INDIVIDUAL:}

1. Dados pessoais:
Idade sexo

escolaridade ( ) $1^{\circ} \mathrm{G}$ completo incompleto

$$
\text { ( ) } 1^{\circ} \mathrm{G} \text { incompleto }
$$
( ) $2^{\circ} \mathrm{G}$ incompleto
( ) $2^{\circ} \mathrm{G}$ completo
( ) superior
( ) superior completo
( ) pós-graduação

\section{Qual a duração do seu mandato?}

\section{Você conhece o regimento do conselho? SIM ( ) NÃO（）}

4. Quando começaram as reuniōes qual segmento que mais tomava decisão?

E agora? Por que?

b. COLETIVO : segmento: 
1. Que ações já foram desenvolvidas como conseqüência da atividade do conselho gestor?

2. Por que elas já foram realizadas?

3. Qual tem sido o papel do conselho gestor:

4. Antes dos conselhos gestores existirem, como a população reivindicava as questões de saúde?

5. O que você acha sobre a composição do seu conselho?

6. Como se prepara a pauta e a agenda das reuniōes do seu Conselho?

7. Quem dirige as reuniōes do seu Conselho?

8. Quem faz a Ata das Reuniões?

9. Como os conselheiros trabalham?

10. Quem tem poder de influência sobre os conselheiros?

11. Há empenho para avançar a proposta dos conselhos de saúde? De quem?

12. Há resistências para avançar a proposta da gestão participativa? De quem?

13. Qual a capacidade de decisão dos conselhos gestores? E de cada segmento?

14. Quem é tido como canal facilitador para se efetivar as decisões do conselho? ou seja: quem faz acontecer as coisas que se decidem?

15. Quais as mudanças visíveis no funcionamento do conselho desde seu início?

16. Quem são os seus aliados para solucionar seus problemas? Como se tem conquistado tais aliados?

17. 0 que se poderá propor para agilizar e fortalecer o controle social no seu conselho?

18. Quais os obstáculos que já foram superados?

19. Como o público fica sabendo das pautas e das reuniões dos conselhos gestores?

20. Como deve ser a capacitação para preparar os conselheiros?

21. $O$ que deve ser feito para que os conselheiros eleitos assumam suas 
responsabilidades com capacidade?

22. O que é bom no seu conselho e o que é ruim?

23. O que fazer para que todos os CGS funcionem efetivamente?

24. O que fazer para facilitar as decisões no Conselho?

25. Como articular melhor a população aos Conselhos? 


\section{ROTEIRO DE ENTREVISTA}

1. Que conquistas as Unidades e os Serviços de Saúde tiveram por influência do Conselho?

2. Em que aspectos o Conselho influenciou e influencia nas politicas de Saúde em Campo Grande?

3. Que outros Conselhos, em Campo Grande, estão ligados às questões de saúde e como eles se articulam?

4. Como está a dinâmica do funcionamento do $\mathrm{CG}$ em relação ao início? melhorou ou piorou? Por que?

5. Quais os pontos positivos do seu CG ? Explique.

6. E os pontos negativos? Por que?

7. Que sugestões você dá para melhorar o funcionamento do seu Conselho Gestor?

8. Qual o papel do fórum dos Usuários do SUS para os CG? 